

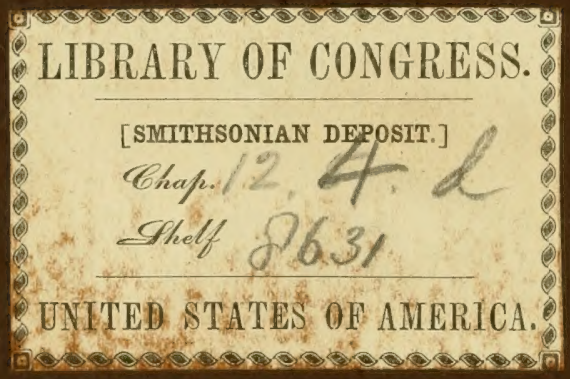






\section{THE HERRING}

ITS

NATURAL HISTORY AND NATIONAL IMPORTANCE. 




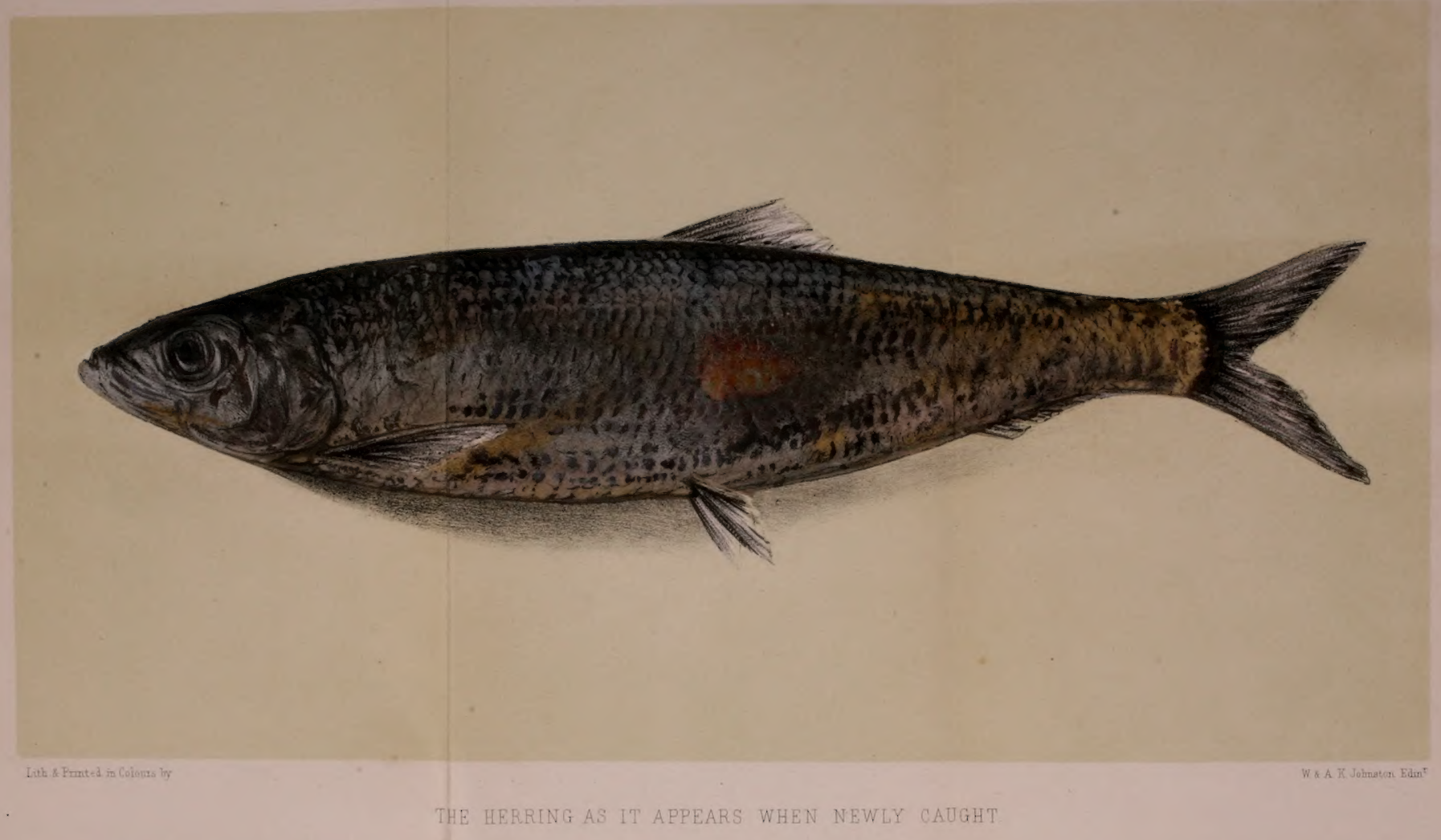


AUTHOR OF THE " NATURAL HISTORY OF THE HERRITG CONSIDERED IN CONNECTION WITH ITS VISITS tO THE SCOTTISH COAST ;" "BRITISH COMMERCLAL LEgISLATION ;"

WITH ILLUSTRATIONS

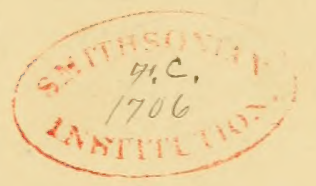

\section{EDINBURGH}

EDMONSTON ALD DOUGLAS LONDON: LONGMAN, GREEN, ROBERTS, AND GREEN 



\section{PREFACE.}

THE Royal Scottish Society of Arts having offered a medal for the best essay "On the Natural History of the Herring, considered in connection with its Visits on the Scottish Coast," the author's attention was directed to the question, and he wrote a short paper on the subject which obtained the medal. This success encouraged him to attempt something more popular and elaborate; and although interrupted by other avocations, he steadily directed his attention to the work which he now brings before the public. In endearouring to obtain as much information as possible, he has frequently visited the fisheries on the West Coast, the Eist Coast, Cormwall and the English Channel, and the coasts of Ireland. He has been on board several of the Dutch fishing-busses, and went to their head-quarters at Vlaardingen and Maassluis; he visited the shores of the Baltic on both sides, and the shores of the German Ocean; resided for some time in Norway, and risited the principal fishing districts in that country. As France is possessed of several important fisheries, he visited most of her priucipal fishing. 
ports from Dieppe to Marseilles, obtaining such information from personal observation as opportunities affordecl.

Portions of this work have been read before the Royal Socicty and the Royal Physical Society, Edinburgh; as well as at the meetings of the British Association at Oxford, Manchester, and Cambridge.

The author believes he has satisfactorily solved the hitherto disputed questions as to food, periodical risits, migration, \&c.; he has also, for the first time, establisher the important fact, that herrings visit our coasts twice in the year,-that, in fact, there is a winter and a summer herring periodically arriving on the different coasts; and already, from this knowledge, additional supplies have been obtained where no previous fishery existed.

The author gives here what has not hitherto been attempted-the Geographical Distribution, and also the Chronological Tisits of the Ilerring, not only on the coasts of the British Islanels, but also on the other coasts where its visits have been ascertained.

The Naturat mistory of the Heming is complehended in Boor Finst;

In Book Second, the Different mones of Fishing AND CURING AT HOME AND ABROAD;

Aud in Book thmo, the progress of the herring FISHERY FROM THF EARLIEST PERIOD TO THE PRESENT DAY aS illustrative of ITS NATIONAL IMPORTANCE.

In the prepratration of this work the author has enjoyed peculiar advantages. Living on the banks of the Forth, 
he has had ample opportunities of examining into the natural history of the herring and its congeners; but he is conscious that many mon enjoying these arlvantages would liave done more justice to the subject. It must be remembered, however, that no such work has hitherto been published written exclusively on the Herring, and therefore the labour has been greater than if he had followed the footsteps of another.

The frontispice represents the herring at the instant it is taken from the sea. Several specimens were photographed by Tumny and by Moffit, for the outline and form. A drawing was made from the best of them, on stone, which was then printed in colours and metals, at the lithographic press, by W. and A. K. Johnston. The evanescent colours were copied from fish immediately after being taken from the water; so that the true appearance of the herring, with all its brilliant iridescent lustre, is faithfully represented.

irayville, Edindurgh. 



\section{CONTEN'TS.}

\section{BOOK I.}

NATURAC HISTORY OF THE HERRING.

CHAP. I.-IMfoetance of the KNowledge of THE NATURAL and Economical History of the Herring,

ChaP. II.-An Account of the Progress and Develophent of tile Herring Fishert, in FURTHER ILluStration OF THE importance of investigating the Natural History of the Herring, .

CHAP. III.-Habtis and Appenrance of the Herring when on tue Consts, . . . . . . . . . . 22

CHAP. IV.-Einemies of the Herring, . . . . . 34

CHAP. V.-Description of the Herring, in Jllustration of its NATURAL History,

CHAP. VI.-The Food of the Herring,

CHAP. ViI,_Periodical Vigits of the Herring, . . . 54

1. Scotland, . . . 54

2. England, . . . . . . . . . 68

3. Ireland, . . . . . . . 70

4. White Sea, , , , , . 73

5. Iceland, . . . . . . . . 74

6. Faroe, , . . . . $\quad 74$

7. Norway, . . . . . . 74 
('HAP. VII.-Periodical Visits of the Herrtal-continuel.

४. Sweden, . . . . . . . . . . . . . . . . . .

9. Denmark, . . . . . . Tfi

10. Baltic, . . . . . . . . . . . . . .

11. Hanse Towns, . . . . . . . . . . .

12. Holland, . . . . . . . . 79

13. France, . . . . . . . . . . .

14. Asia, . . . . . . . . . . . . . .

15. Behring's Straits, . . . . . . . $\ 1$

16. Bathurst Inlet, . . . . . . . . . \&1

17. America-United States, . . . . . . 81

18. Nova Scotia, . . . . . . . . . . . . .

CHAP. VIII-Migration, . . . . . . 81.

\section{BOOK IJ}

\section{ON FISHING AND CURING.}

CHAP. I.-OF mhe Different Modes of Fishing the Herring, 91

1. The Scotch Method, . . . . 91

2. Yarmouth Fishery, . . . . . . 95

3. Hastings Fishery, . . . . . 98 98

4. Irish Coast Fishing, . . . . . . 98

5. Dutch Fishery, . . . . . . . 101

6. Norwegian Fishery, . . . . . . 105

7. Prussian Method, . . . . 108

8. Gulf of Bothnia, . . . . . . . . 109

9. Belring's Straits, \&c., . . . . . . 110

CHAP. II.-Different Modes of Curine, . . . . . 111

1. Scotch Mode, . . . . . . . 111

2. Dutch Mode, . . . . . . . 115

CHAP. III.-Curing or Prepartag Smored or Red Herrings, 120

Mode of Curing Sardines in France, . . . . . 124

Erench Mode of Curing Sardines (or Sprats) in Oil, . $\quad 126$ 


\section{BOOK III.}

\section{CHRONOLOGICAL HISTORY OF THE HERRING FISHERY.}

CHAP. I.-From the EARLIest Period to the Appointment of Commissioners tN 1808,

Anent the Making of Schippes and Busches on the quhilk all idle men suld labour,

The Time of Selling of Fish in the Mercat; anent the Waycarrying of Fish ; of the Price of Fish,

Measures of Fishe shud be marked,

Herrings and Quhite Fishe suld be brocht to Free Portes within the Realme,

Fish slain on uther side of the Water of Forth may be brocht to ony Free Burgh, . . . . .

Anent Victualling of Schippes passing to the North Fishings, and Caution to be found for their returning,

Act for Fishing and erecting of Companies for promoving of the same,

Act anent the Fishery, . . . . . . . 17

Act anent the Loyal Curing and Packing of Hemings and Salmon Fish, . . . . . . . 176

Act for the Encouragement of White Fishing and HerringFishing,

Act for Advancing and Establishing the Fishing Trade in and about this Kingdom,

CHAP. II.-From the Appointment of the Commissioners of the Brimsin Fisieries in 1808 to the Present Time,

Fishery Convention Act, 22d August 1843, 6 \& 7 Vict. cap. 79 ,

Report on the Expenditure under the Superintendence of the Scotch Fishery Board, 
CHAP. II.-continued.

Questions for a Series of Observations to solve the Natural History of the Herring, ordered by the Lords of the Committee of Privy Council for Trade,

Additional Questions in aid of the Observations to solve the Natural History of the Herring, ordered by the Lords of the Committee of Privy Council for Trade, . . 305

Report, 1858, of Dutch Herring-Fishery 1857, . . . 307

On Trawling in Galway Bay, . . . . . . . 331

Diving for Spawn, . . . . . . . . 341

Herrings Fished or Cured in 1862, . . . . . 344

Suggestions as to the Improvement and Extension of the Herring-Fishery, . . . . . . . . 349 INDEX, . . . . . . . . 357

\section{ILLUSTRATIONS.}

Frontisipiece.-The Herring as it appears when talien from the Ser.

Plate II.-Clyde Herring Fishing-boat; Irish Skerries Hooker; and Isle of Man Herring-boat, . . . . Page 27

" III.-Penzance Herring Fishing-boats, . . . . . 69

" IV.-Herring Busses of Holland, . . . . . 102

" V.-Newhaven Herring-boat, newly introduced, being Decked, . . . . . . . 297

". VI.-French Fishing-vessels, . . . . . . 324 


\section{B O O K I.}

\section{NA'IURAL HISTORY OF T'HE HERRING.}

\section{CHAPTER I.}

IMPORTANCE OF THE KNOWLEDGE OF THE NATURAL AND ECONOMICAL HISTORY OF THE HERRING.

IT may be questioned whether any branch of natural history is so important, in a national point of view, as that relating to the herring. An improved knowledge of its habits may enable us to add greatly to the success of the fishery, and therefore to the uational resources; and an inquiry into its economical history, into the causes of the wonderfully rapid and successful progress of the fishery, may teach us how much a nation may gain by judicious care and legislation.

The importance of the lierring as a source of wealth and power has been acknowledged by every maritime nation; and it may be truly said, in the language of the editor of Baron Cuvier's "Natural History of Fishes,"*

* "Par son inépuisable fécondité le hareng est une de ces productions naturelles, dont l'emploi décide de la destinée des empires. La graine du caféier, la feuille du thé, les épices de la Zone Torride, le ver qui file la soie, ont moins influence sur les richesses des nations que le hareng de l'ocean septentrional. Le luxe ou le caprico demandent les premiers, le hesoin réclame le second. La pêche de ce poisson fait partir, chaque année, 
that "the coffee bean, the tea leaf, the spices of the Torrid Zone, and the silkworm, have less influence on the wealth of nations than the herring of the northern seas. Luxury and caprice may seek those productions, but necessity requires the other. This fishery sends every year, from the coasts of France, Holland, and Britain, numerous fleets to collect, from the depthis of the stormy occan, an abundant and certain harvest, which the vast shoals offer to the courageous activity of these nations. The greatest statesmen, the most intelligent political economists, have looked on the herring fishery as the most important of maritime expeditions. It has been named the Great Fishery. It forms robust men, intrepid mariners, and experienced navigators. The nations industriously occupied in this fishery know how to make it the source of inexhaustible riches."

We show in our chronological history of the herring fishery the great excrtions made by the British nation at various periods to promote and encourage its progress; and we there explain some of the causes of the want of success, doubtless occasioned by the want of information on the natural history of the herring, and the consequent erroneous legislation. We shall here, therefore, only briefly give proofs of this. By Act 23 George II. cap. 24, passed in the year 1750 , bounties were offered for the fitting out of busses to fish lierrings, but they

les côtes do France, de Hollande, d'Angleterre (de la Grand Bretagne), des flottes nombreuses pour aller chercher dans le sein d'une mer orageuse la moisson abondante et assurée que ses legions innombrables presentent à la courageuse activité de ces peuples. Les grands politiques, les plus habiles economistes, ont vu dans la pêche du hareng la plus importante des expéditions maritimes. Ils l'ont surnommée la grande pêche. Elle forme des hommes robustes, des marins intrépides, des navigateurs experimentés. L'industrio qui s'empare des produits de cette pêche sait en faire l'object d'un commerce, source des richesses inépuisables." 
were ordered to proceed to the fishery at erroneous periods, namely, "to rendezvous at Campbelton, on the west coast, un or before the 1st of September, and to continue fishing to the 31st December." The dates for this fishery ought to have been on or before the 1st of June, and to the 30th September. Another Act was passed in 1753, the Act 26 George II. cap. 9, whereby it was enacted, that to entitle the busses to the Government bounty, they were to rendezvous at Kirkwall on or before the 12 th September, and to continue fishing to the 1st January; while the dates, to enable the fishermen to fish herrings when they were on the coasts, should have been to rendezvous at Kirkwall on or before the 12th June, and to continue fishing till 1st October. This system of error continued for a long period, and it was only after the establishment of the Fishery Board, consisting of a body of unpaid commissioners, who fortumately were, and whose successors also were, intelligent and patriotic men of high standing, that a fishery, till then of little importance, has become one of the greatest, if not the greatest, and most prosperous in the world. The whole system, carefully and economically managed by the Board and its officials and local officers, combined with judicious legislation and arrangement, has insured that eficiency and success which entitles it to be characterised as much superior to any similar existing institution either at home or abroad.

The great importance of the natural history of the herring is attracting at the present time the attention of several of the principal maritime nations. We may mention, to prove this, that au interesting discussion took place at the French Academy in 1855, on the question of the migration of the herring, but with no satisfactory or elucidating result, from the want of knowledge of facts.

A 2 
The authorities of the kingdom of Norway have also been occupied for several years past in legislating with the view of promoting the herring fishery on the Norwegian coasts; and we have seen several of their laws and regulations, which prove how far inferior the system has been in that country as compared with ours. An elaborate printed report, which was prepared by the chief of the Royal and Civil Department of Sweden, Von Wright, and printed by order of the King of Sweden, entitled "Handlingar Rörande Sillfisket" (Report on the Herring Fishery of Sweden), endeavouring to give the natural history of the herring, and to point out the cause of the almost total failure of the herring fishery on the Swedish coasts, was not long since published.

The Dutch Government is anxiously employed at the present time in obtaining every information on the subject, and has requested and authorised the Royal MLeteorological Society of that kingdom to obtain observations and statistics as to the habitat and natural history of the herring; and under one of their scientific naval officers, tabular reports of the results of the observations made on board of forty-five Dutch herring busses, are giren in a work published by authority of the Dutch Government, and which has been considered of such importance that the British Lords of the Privy Council for Trade have ordered a translation of it to be made, and printed for general information.

And thus, determined to promote or improve the herring fishery of Holland, which had fallen off to a great extent, the Dutch Government has, within these few months, relaxed and altered the old fishery laws, and established a Fishery Board, modelled on the plan of the British Fishery Board, knowing, no doubt, the great good done 
in this country by the system of management and organisation established by the Board in this country.

The Lords of the Privy Council for Trade of this country have also directed their attention to the subject of the natural history of the herring, and have sent to the various fishing-stations printed circulars, entitled-

"1st, Questions for a series of observations to solve the natural history of the herring.

" $2 d$, Additional questions in aid of the observations to solve the natural history of the herring."

The answers required, if given, may go partly to establish a fow of the facts which we endeavour to elucidate on the natural history of the herring; but until the present time, no report has been published of the answers obtained by the Board of Trade. We have therefore no doubt that the same kindness shown by our Government to foreign nations as to the fisheries at Newfoundland, the British American coasts, and on the Scottish coasts, caused the Government to endeavour to obtain auswers to these inquiries, for the purpose of aiding the Dutch Government to pursue their inquiry as to the best means of restoring the Duteh herring fishery, the object in view, as stated by the Dutch Meteorological Socicty in their report.

We therefore consider that it is a reproach to this country that no separate or satisfactory work has yet been written by any one, from actual experience, to elucidate the natural history of this the most important of the finny tribe, far surpassing in value, and as a source of wealth, prosperity, and maritime strength, every other that can be namerd.

Many statesmen, even such statesmen as are referred to by the great French authority, may look on the auriferous 
deposits and gold diggings as worthy of more attention and more legislative care and protection; but if so, they are egregiously wrong. What benefits have the gold diggings of America conferred on the people of Spain? None. Nay more, some of the best and wisest philosophical writers have shown that the curse of too much gold may fall on a nation as well as on an individual; and those probably speak the truth who say that the greatness of Spain began to decline from the period when the gold mines became abundant, and the gambling spirit for the ac:quisition of gold deadened enterprise and industry, and that therefore the Spaniards sunk into a state of lethargy or indolence; and that, although deprived to a great extent of the cause, they still suffer from the consequences, and may be said to be only slowly advaucing towards the recovery of their former position among the nations of Europe**

To prove the necessity of endeavouring thoroughly to investigate and carefully to study the natural and economical history of the herring, several glaring errors in some works of the very highest authority may be pointed out, more in justification of the attempt now made to throw as much of the light of truth as possible on a subject which involves the wellbeing and prosperity of a large aud industrious population, than from any desire to depreciate works otherwise of the most elaborate and interesting description.

* In encouraging the search for gold in our own colonies, are we not losing, or sending away from our mother country, some of our most enterprising and useful inhabitants, not easily to be replaced? In encouraging the search for herrings on our own coasts, as truly said by the distinguished French author already quoted, we create those men of so much use in a maritime nation, "intrepid and robust mariners," besides adding annually additional supplies of food and "inexhaustible riches." 
In Barou Cuvier's valuable work on the Natural History of Fishes (which contains very considerable, and, to some extent, interesting (letails as to the herring), edited and enlarged by Professor Valenciemnes of Paris, several errors exist which it is necessary to refer to, seeing that this is a work of the very highest authority. At page 35, vol. xx., in the "Histoire Naturelle des Poissous," he says: "Les plus grandes exemplaires que nous recevous sur nos marchés n’ont guere que dix pouces, a dix pouces et demi, de longeur, mais nous voyous le hareng atteindre a des dimensions beaucoup plus considerables dans les mers du nord, nous en avons reçu du Musée de Berghem (Bergen) de treize pouces et demi de longeur. Une remarque qui est importante c'est que dans ces mers Septentrionale jusque dans les mers Blanc, tous les individus ont une grosseur invariable, toujours superienne a celles de nos harengs de la Manche dont les petites dimensions sont egalement constantes." This statement is incorrect. It is true that the herrings fished in winter, or the end and the beginning of the year, on the coast of Norway, are very large in size, and that some are $13 \frac{1}{2}$ inches in length. But in summer large shoals of another description of herring, not young herrings, but with milt and roe, approach the Norwegian coasts, and are fished in considerable quantities, and constitute an important fishery every year, which are not larger than the herring of the said Manche or English Channel; and even in some seasons on the coast of Norway they are not larger than the seventh class, and therefore smaller than the herrings which appear on some of our Scottish coasts and in the English Channel.

At page 49 of the same volume, he says that the distinguished naturalist Noel de la Morienicre (whose acquaintance we had the pleasure to make when he was 
in this country), informed him that these herring's which were ready to spawn were sometimes found with young fish in their stomachs; and that these herrings were called in Scotland "woolfish." This term is not used in Scotland. It may perhaps mean either full fish or foul fish. The first term may be applied to the herring full of milt or roe; but the latter term is seldom if ever used by practical men; and, indeed, is never applicable to the herring in any of its stages, because it is wholesome food though full, and not unwholesome food either spawning or spawned. To prove this, it may be stated that several thousands of barrels of empty lierrings are exported and used as food, and found to be perfectly wholesome.

He states also as his opinion, at page 58, that the herring spawns indiscriminately anywhere, without selecting any position, even in the middle of the sea (" au milieu de la mer"); but had Professor Valenciennes taken the same trouble that others have taken, or had the same opportunities to ascertain the truth as to this operation which so materially interests us, having regard to the preservation of this important fish, he would have found that the herring is extremely select as to the spawning ground, and does not spawn in the open sea, or "au milieu de la mer." And Professor Valenciennes seems to be not aware that the greatest shoals of herrings come to our shores, and are fished in greatest quantitics, in summer and autumn ; for in page 62 of vol. xx. he says, "C'est pendant l'hiver qu'ils apparaissent sur les côtes d'Europe." "It is during the winter that they appear on the coasts of Europe."

Next, Mr Yarrel, in his excellent " History of British Fishes," is in error where he says-"our common herring spawns towards the end of October or beginning of No- 
vember, and it is for two or three months previous to this, when they assemble in immense numbers, that the fishing is carried on, which is of such great and national importance."

Now, this "common or summer herring", which visits the eastern coast of Scotland in summer, spawns about the end of September and beginning of Octoher. But other large shoals, the winter herrings, visit our Scottish. coast in November and December, and sparwn in February and March. Therefore our coasts have both summer and winter herrings; and but for the uncertain or tempestuous nature of the winter season, it might yield as large supplies as the summer fishery. The Chupea Leachii, which Mr Yarrell describes as being only $7 \frac{1}{3}$ inches in length and 2 inches in depth, with pale yellow irides, is altogether unknown on the Scottish coasts.

Mr MI'Culloch, in his "Dictionary of Commerce," gives Pemnant's strange theory of the herrings "coming in vast shoals from the icy ocean ;" we shall prove, however, that there is no foundation for this statement. He then says, that "the Dutch have uniformly maintained their ascendency in the herring fishery since the earliest period." Now, on the slightest inquiry, Mr M $\Gamma^{\circ} \mathrm{Culloch}$ would have found that this is an error. The Dutch herring fishery has gradually declined, and the Dutch do not now cure above 20,000 barrels; while the Scotch cure annually about 500,000 barrels, which obtain an equal price with the Dutch in every continental market. He then states, that "owing to the Reformation, and the relaxed observance of Lent in Roman Catholic countries, the demand for herrings on the Continent is now far less than in the fourtecnth and fiftecnth centuries." This is also a palpable error. The Roman Catholic countries not only still 
consume large quantities in Lent as well as other periods of the year, but the demand on the Continent has not necessarily ceased or diminished on account of the Reformation. So far from this being the case, the Protestants as well as the Roman Catholics are great consumers of our Scottish herrings; and there can be no doubt that the consumption of these herrings on the Continent has been annually increasing since 1815 , in which year the number of barrels exported to the Continent was only 35,891 , while 344,029 barrels was the quautity of Scottish herrings exported to the Continent in 1855 , and which, there is no doubt, is a much larger quantity of herrings than was imported by the Dutch into the Continent in any one year either in the 13th, 14th, or 19th century.

The next quotation is rather a long one, but it is so utterly at variance with what is generally known to be the case, that it is extraordinary that it has not been sooner contradicted. The paragraph begins: "Importance of the Herring Fishery. Progress in Great Britain.There is perhaps no branch of industry the importance of which has been so much overrated as that of the lierring fishery. For more than two centuries, company after company has been formed for its prosecution; fishing villages have been built, piers constructed, boards and regulations established, and vast sums expended in bounties, yet the fishery remains in a very feeblo and unhealthy state." After making these statements, we should have expected to have been informed by the author in what way "the importance of the herring fishery was overrated." The mere assertion that fishing villages lave been built and piers construeted do not prove that the importance of the herring fishery was overrated. If the villages were built, they found inhabitants ; if piers con- 
structed, they were required, and, in truth, are not so capacious nor so numerous as are required for such an extensive fishery. But the fact that the herrings cured in Scotland have increased from 35,000 barrels to 500,000 barrels annually, and upwards, gives a direct negative to the statement that "the fishery remains in a very feeble and unhealthy state."

The author then quotes a paragraph from an obscure paper, the "Quarterly Journal," to the effect that the fishing bounties had called forth a number of landsmen to fish and cure herrings who only prosecuted the fishery from June to September. They certainly could not fish herring's but at the season when they could be procured. But this assertion is erroneous when applied to the inhabitants of fishing villages, whose profits arising from the herring fishery enable them to prosecute with success the other fisheries; in short, to ply their calling with success the whole year through.

As to the expenditure of the public money on bounties and premiums, it may be seen that the public money hitherto expended has been of a comparatively small amount. It was to enable our own busses to compete with the foreign busses on equal terms; for the bountics given were not equivalent to the enormous custom duties paid to Government on the raw materials required in the construction and equipment of the busses, and for nets and other requisites; and even these bounties were irregularly paid, and at one time altogether withheld, to the ruin of many of the Scottish merchants. In truth, the herring fishery has become prosperous in spite of every obstacle thrown in its way by the erroneous Government exactions and prohibitions, and its progress under so many difficulties is much owing, as already remarked, to 
the judicious regulations and superintendence of the Fishery Board and its officers.

We shall now notice another work, which we consider of still greater authority than $\mathrm{I}^{\text {'Culloch's "Commercial }}$ Dictionary." We allude to what has lately issued from the press (1857) of the last edition of the "Encyclopædia Britannica." The author of the article "Ichthyology" also adopts Pennant's erroneous theory as to the herrings "coming from the Icy Ocean" to this extent, that he quotes it, and says, "In truth, we are not furnished with sufficient data to decide the question; but in the meantime we do not feel inclined entircly to reject the generally received opinion, that the herrings migrate from north to south in summer and autumn;" and he then proceeds to describe the "vast troops" which Pennant so fabulously mentions. He says, "The shoals are generally preceded, sometimes for days, by one or two males,"a very difficult fact to ascertain that "one or two males preceded, sometimes for days, the said shoals." And he then says, that "the largest generally go first," and that they "act as guides." Surely it is impossible for any luman being to know the truth of this statement from actual observation. He then says, "it is generally believed that the herrings captured far north are larger, fatter, and of a better quality than those of the south; and for this reason, in the month of July our fishermen go out to meet the shoals as far as Orkney and Shetland." This is a most extraordinary statement to be published at this time at Edinburgh, the headquarters, we may say, of the Scottish herring fishery. It is not generally believed "that the herrings captured far north are fatter and richer." We do not know any individual of any practical acquaintance with the subject who believes this; 
and "our fishermen do not go far north, to Orkuey and Shetland, to meet the shoals." The herring fishery off Orkney and Shetland is confined to the local boats, as far as Scotland is concerned, and the herrings are certainly larger; but unquestionably they are the reverse of being "fatter and richer" than the herrings of the localities further south, particularly on the west coast. He then says, "the greatest number are taken on the coasts of Norway and Sweden, in the first of which countries it is said that about 400 millions are taken in one year, and sometimes 20 millions in a single fishery." "The inhabitants in the neighbourhood of Göthenburg, in Sweden, take as many as 700 millions in a year." These statements are erroneous. The greatest number of herrings is taken on the coasts of Scotland, and generally exceeds the number taken in Norway; and so far from the inhabitants in the neighbourhood of Göthenburg, in Sweden, taking "700 millions in a year," lately or at present, there has actually been no herring fishery to any extent there since 1808; and, indeed, there are now hardly any caught on the whole coast of Sweden. Seven hundred millions are about one million barrels of herrings! We know that the herrings forsook the coasts of Sweden fifty years since, and yet here is a work of undoubted pre-eminence telling us that one million of barrels of herrings are annually fished noar Göthenburg at present, while no fishery exists in that locality to any extent! This account has been given with every new edition of this work, which is admittedly of the very highest authority. 


\section{CHAPTER II.}

AN ACCOUNT OF TIE PROGRESS AND DEVELOPNENT OF THE HERRING FISHERY, IN FURTHER ILLUSTRATION OF THE IMPORTANCE OF INVESTIGATING THE NATURAL HISTORY OF THE HERRING.

The herring fishery has been increasing with steady, as well as rapid progress, since 1808, when the Fishery Board was established. In that ycar there were cured, 90,185 barrels, and in the year ending December 1855, 766,703 barrels, besides the quantity caught and sold fresh, 130,759 barrels; making the total quantity of herrings caught in $1855,897,462$ barrels. The great increase of this fishery has tended in no small degree to increase the wealth, and the number of the population of the Scottish coasts; and the annual addition of the value of the herrings must have a great and beneficial influence on the prosperity, not only of Scotland, but of the British Islands. The addition of nearly one million sterling every year to our national wealth must be extremely gratifying to every patriotic mind. The success of the enterprising inhabitants at the old curing stations roused the exertions of the inhabitants of other places where the fishery had not been before attempted; while the fishery had been carried on for many years 
previously in a regular manner, in the Clyde, the Forth, off Berwickshire, and the counties of Sutherland and Caithness: it is only since 1815 that extensive fishery stations have been established in Aberdeonshire, Banffshire, Morayshire, and Ross-shire; at Lossiemouth, Portsoy, Cullen, Portknocker, Findochty, Portessic, Banff, Whitchills, Maciduff, Gardenstown, Rosehearty, Pitaillie, Fraserburgh, Peterhead, \&c.; and these have become noted places for herrings of the best quality, and as such have added greatly to the number, and the wealth, and prosperity of the inhabitants.

The increase of the herring fishery depends very much on the demand for exportation, and this demand requires to be carefully cultivated, not merely by the curers, who may be viewed as the manufacturers of the goods, but by the Government, which, by impartial and just legislation, protects the interests of the fisherman, the consumers at home, and the morchants and consumers abroad. That there was an abundance of herrings on the Scottish coasts was known for centuries past; but when considerable quantities of them appeared, they were of little remunerative value when caught, because the demand was limited to the mere local consumption. Before the specific and legalised size and quality of the manufactured article-the harrel of well-cured herrings-could be obtained as goods for commercial purposes, a merchant abroad could not buy herrings in Scotland, there having: been no legal distinct specific form and quality. The curer might say, my barrels are of every size, and various in quality and price; but the foreigner could not order nor buy such goods, and he therefore bought herring's which were of legalised size and good quality elsewhere; and, although he paid a high price, he obtained what he wished 
in Ifolland and other countries: and these countries are rearly to supply any quantity if Scotland should be malle to do so.

Before a proper system of legislation was adopted in this country, and even for some time after the system was introduced, the demand from abroad was inconsiderable; hut confidence having been given from years of experience, and the trade based on a solid foundation, under legal enactments fixing measure and quality, the business progresses, and bids fair every year to extend and increase. To prove the progress of the increase, we may state, that in 1812 the total quantity of herrings cxported to the Continent was . . . 4,720 barrels. In 1815 it amounted to . . . 35,891 " 1840 1845

1850

1855
82,515 " 143,754 . 257,108 "

If any evidence were necessary to prove that a fixed legal standard, applying to quantity as well as quality, is necessary to ensure success, this statement is all that can be wished. But we have more direct and convincing evidence still; for when the curers in Scotland thought any size and quality of herrings would sell abroad, and persisted in attempting to supply foreign markets, the attempts were failures, - and the demand for fresh herring being limited, the price was so low as not to induce fishermen to proceed to fish, and there was a limited or losing trade. But additional evidence that a staple article, at a fair price, will obtain its position in the market, is olstained by the account of the importations at one of the principal importing ports on the Continent (Stettin) for a series of years past. 
In 1825 there was imported there of white herrings in barrels, from

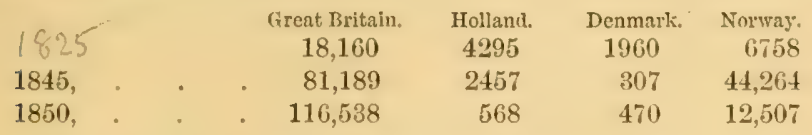

Thus, in 1825 the British herrings imported at Stettin was not much more than the whole quantity imported from other countries. In $18+5$ it was nearly double the quantity imported from all the other countries put together; and in 1850, the demand for Scottish herrings increased so much, that it formed about nine-tenths of the whole quantity imported. In short, while the quantity exported from this country to Stettin increased amnually, and in proportion to the supply at home, the herrings of every other country imported at Stettin have annually diminished. In 1855 the quantity exported to Stettin of Scottish herrings was 160,572 barrels, being about nine times the quantity sent from this country in 1825 , double the quantity in 1845, and more than a third greater than the quantity exported thither in 18.0\%. It might also be shown that the quantity sent to other places has been every year increasing; but we shall only here give the exports in 1855 . There were exported in that year to

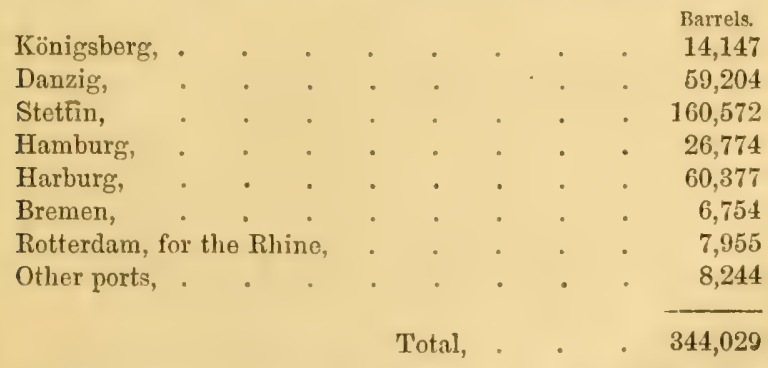

The numerous ports and places where the herrings 
are caught or cured show how widely extended the fishery is on the Scottish coasts. The following is a list of the stations or districts, and quantity cured in 1856 at each, viz.:-

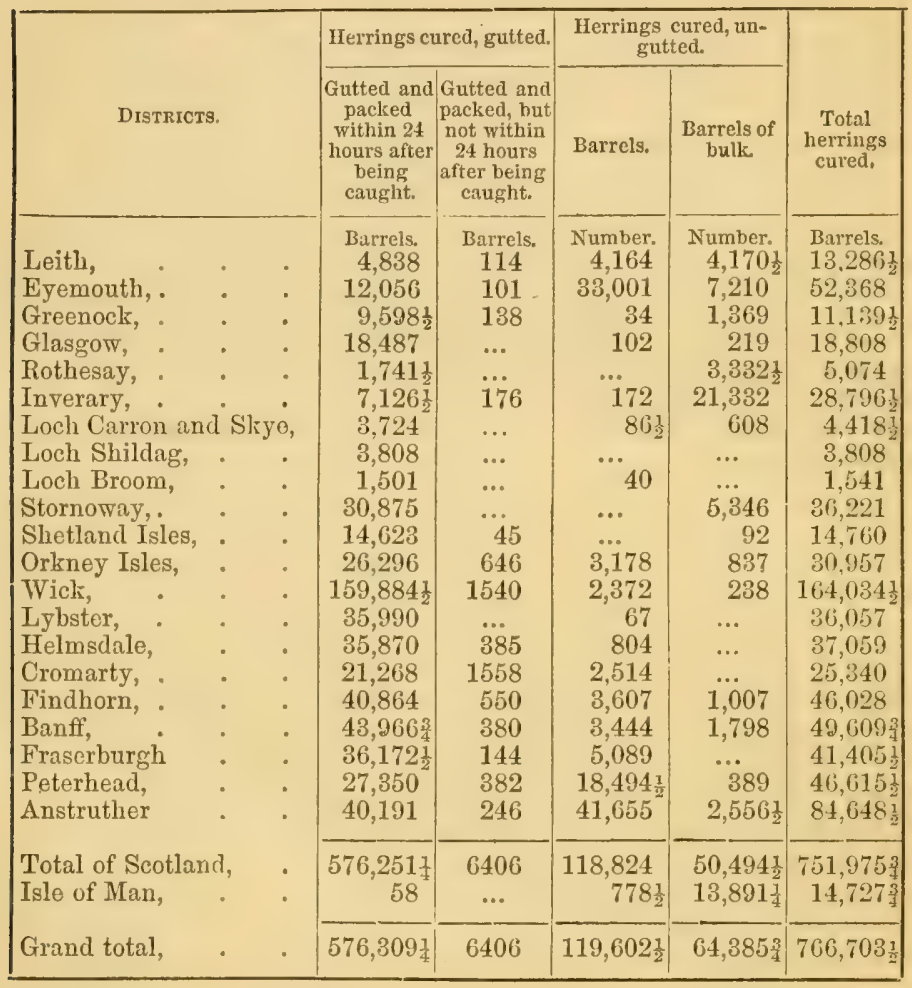

But perhaps the most satisfactory statistical account that can be given is the statement of the number of people and boats directly employed in the Scottish fisheries; and we therefore give, in as condensed a form as possible, the number of boats, their tonnage, and the people employed. 


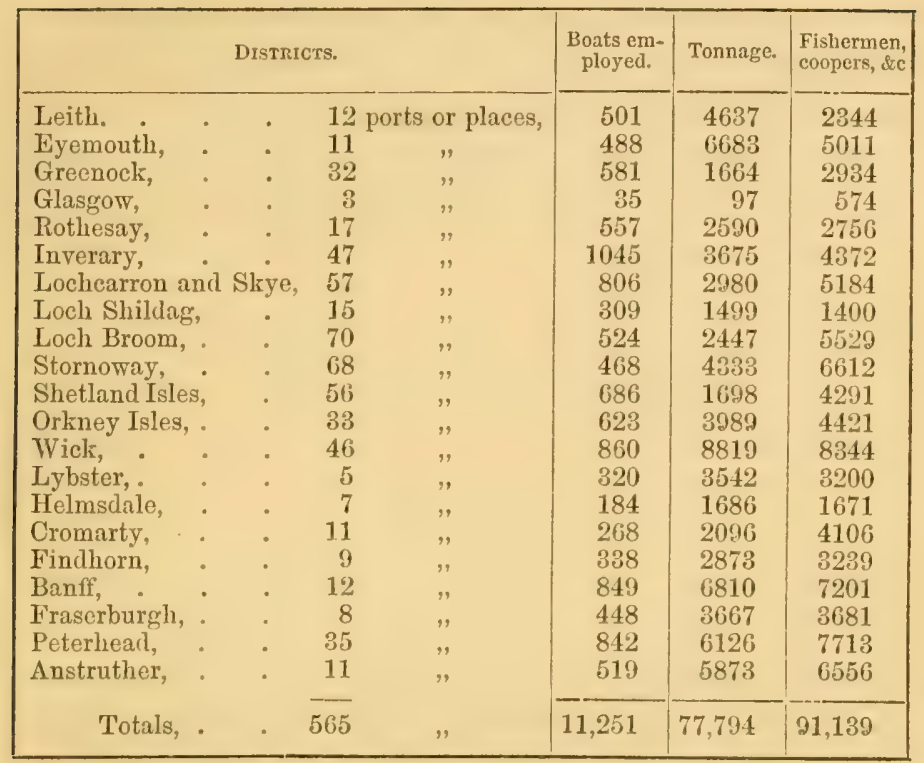

Of these 91,139 people directly employed, 39,266 are fishermen; but if we add those employed indirectly by the money derived from the fishery, namely, the boatbuilders, sailmakers, ropemakers, mastmakers, saltmakers, grocers, carters, porters, shipowners, sailors, and other trades, the number will appear incredible to those who have not had an opportunity of elosely observing the incalculable benefits accruing to the nation from the prosperous state of such a fishery. Here we see employment to the industrious classes, while they are addiug an abundant supply of cheap and wholesome food for the numerous population of the British Islands, when other animal food is becoming so scarce and expensive.

The great extent of the commerce that arises from the fisheries may be judger of from the number of ships and 
men employed in importing salt and materials for the fisheries, in conveying the fish on the coasts, and carrying the same to British or foreign ports. By the Report of the Honourable Commissioners of the Fishery for 1856 , page 42 , it appears that the tonnage of shipping so employed amounted to . . . . 119,148 The number of seamen . . . $\quad 9,685$ And the number of square yards of netting

used in the herring fishery was . 76,661,187 Valued at $£ 309,866$ And the value of boats employed . $£ 211,585$ It would be difficult to give any correct estimate of the capital employed by the fishcurers in Scotland; but when it is known that in 1855 there were 1054 fishcurers directly employed in purchasing herrings and curing them for the home and foreign market, it may be supposed that the capital put in circulation must be very great, without reference to the amount circulated by those merchants who principally carry on business in buying the cured herrings.

The more rapidly the manufactured articles cease to be of use the more employment is offered to the people; and as the fishing vessels or boats last only a few years, and the nets a shorter time, and as the barrels are generally only available for one year, the continual employment of great numbers of the working classes in procuring the materials and making them is of no small advantage to the community, and a ready sale is besides afforded for numerous cargoes of hoops from the English, and of wood from the Scottish forests, as well as from foreign countries.

We think it necessary thus to point out not only the great extent, but also the great importance of the her- 
THE NATURAL HISTORY OF THE HERRING.

ring fishery, as proving how much the knowledge of the natural history of the herring is connected with the prosperity of these kingdoms; for without such knowledge the important fishery is in danger of being destroyed. 


\section{CHAPTER III.}

HABITS AND APPEARANCE OF THE HERRING WHEN ON THE COAST'S.

IT is extremely interesting to observe the herring when on the different coasts or fishing-grounds at the usual seasons of their approach. On some of the coasts, as on those of Norway, the herring shoals are frequently accompanied or pursued loy numbers of whales and aquatic birds, which are all occupied in preying on them. The large dark masses of the whales rising and blowing and throwing up great quantities of the herring into the air, sparkling and glittering in the clear winter day; the constant movements of the birds with shrill notes actively engaged in seizing their easily-obtained food, vying with man in their attacks on the countless myriads of herrings; and the appearance of numbers of fishing-boats and vessels, with the sound of the voices of an active body of fishermen-the ocean on the one side, and the dark and lofty rocks on the other-is one of the most extraordinary and interesting sights that can be contemplated.

The whales which thus principally prey on the herring are the Balcena musculus and Balcena balcenoptera, 
and not the Balcena mysticetus, or common whale, which has been hitherto erroneously supposed by many to feed on the herring.

It is not usual, or often, that such appearances of whales accompanied by aquatic birds pursuing or preying on the herring, occur on our coasts; but such a scene, as occurs so commonly on the coasts of Norway, is sometimes seen on our own. For instance, in the bay of Cromarty, in 1780 , a large shoal of herrings appeared, accompanied with vast numbers of whales and porpuises beating the water into a foam for several miles, giving it the appearance as if rufled by the sudden land squalls which blackon the surface. Another season, in autumn, the bay of Cromarty appeared as if its countless wares were covered with fish and birds; no fewer than seven whales were seen within the short distance of half-a-mile, some of them apparently sixty feet in length, and when they spouted, the water thrown up was mingled with fishes, which had a brilliant effect in the sunshine (see description of Moray Firth Herring Fishery, by the late Hugh Miller). And again, in the year 1816, on the coast near Fraserburgh, a shoal of herrings, which afforded a rich harvest to the fishermen, was accompanied or pursued by about 100 whales of various sizes, which remained seven days, namely, from the 24th to 30th August, in the same locality, accompanied by numbers of aquatic birds. This unusual sight was observed from Kimmaird's Head by many of the principal inhabitants. The herrings were of a good size, about the size of the eighth class, were full of milt and roe, and considered by the fish-curers then at Fraserburgh to be of very superior quality.

On the different coasts, and in many of the bays where the herring resorts, there are sometimes, to a smaller ex- 
tent, during the summer, appearances of whales, and porpoises, and birds that prey on the herring, which afford indications to the fishermen where the greatest abundance of herrings are; and one fisherman, who was lately fishing off Stornoway, informs us that, while the other loats were unsuccessful, the appearance of a whale at a certain distance induced him to cast his nets near the whale, when he was very successful, having taken forty-eight crans, or barrels, of very superior herrings, while the other boats obtained only small quantities. In the beginning of the fishing off Dunbar, if there is no appearance of herrings, the fishermen, knowing that the gannet feeds on herrings, watch this bird, and procure it by shooting or otherwise, and then examine the stomach, and if they find herrings in it, they are able to judge of the position of the shoals; and by opening the stomach of the cod they have discovered shoals of herrings which had left the fishing-ground where they had been previously fishing, and obtain, as they have done in this season while we write, a large additional supply of herrings.

During the day the shoals are sometimes observable near the surface, and may be seen playing on the water, as the fishermen call it, "making a ripple," a dark roughness similar to what we may see at the beginning of a slight breeze, and this is sometimes observable without the appearance of either whales or birds. The passing near or over them, of a boat or ship, makes them instantly dart off in every direction, leaving the appearance of long trains of light, if at night. We have been informed by two of the most intelligent fishermen of Newhaven, that the herrings take considerable flights out of the sea. Off Stonehaven, in the month of September, one of these men saw a shoal, after the spawning season, rise up out of the 
water in a vast mass of many yards in extent, sparkling and flashing, and flying several feet above the surface. Another, when fishing for herrings above Queensferry, saw, during the early daylight, a small shoal rise out of the water, fly several feet above the surface, and pass over to the other side of his nets. Both these men are quite trustworthy. The herrings were perhaps pursued by dogfish.

We have several times accompanied the fishermen in their boats to the fishing-ground, that we might become acquainted with the appearance of the herring when on our coasts, and to ascertain, if possible, the rule which guides the fishermen in their search for the best fishingground. There is something very pleasing and exciting when the night is very dark, and the moon, of course, not shining; the boat rises and falls in a dark mass of water, the water sends phosphorescent particles around the boat at every stroke of the oar, the other boats are heard or seen moving in the same direction. At the bows are piled the nets ready for casting into the sea. Now and then we come near the herrings, which to the eye appear quiescent for a moment, in an instant they turn slightly on one side, as if to look up at the boat, and quickly dart off, each herring forming a line of fiery light.

We found, generally, that the fishermen had no rule for selecting their fishing-ground, except their kuowledge that a certain distance from the shore was the most suitable, or that the spot chosen by them was prolific in herrings on a previous occasion. They have, however, to judge as to the best mode of placing the nets in connection with the flow of the tides, and the safety of the nets and boats, and the depth of the sea; taking all these, of course, into consideration, with the view of 
making a successful capture of herrings. The nets having been thrown overboard, if there is no shoal near the spot, or no great appearance of herrings, the fishermen take in part of the net to see if there is any taken; and, if there is a scant appearance, they take up the nets and proceed to some other place. They generally have a watch of one or two of their number at the bows of the boat, and in some localities they may be hunting after the herrings, either sailing or rowing, a considerable part of the night. Here and there they sce, perhaps, one or two herrings as they pass along darting aside like masses of fire, then they see them more closely together, and in certain states of the atmosphere they are guided by the reflection of the light from the herrings "as if there were a fire burning under the waves." When this occurs, the fishermen throw the nets out with every chance of success. The net is generally taken in by dawn, and nothing can exceed the brilliancy and beauty of the tints of the herring when taken out of the sea. Most of the herrings appear to have been killed in the nets, as very few come into the boat alive. The nets form a straight line, when in the sea, of considerable length, the boat beirg generally attached to the one end (in other cases the nets are anchored at each end), it is almost difficult to understand why the herring, or any other fish, gets entangled in a wall of netting, and why, with the power of vision it possesses, it does not move away from it. The mesh is square, and is, or ought to be, exactly one inch, being adapted to the size of the herring, which is generally caught by the head. It frequently occurs, that while there are considerable numbers of herrings, at certain times they do not come into the nets; and, according to the language of the fishermen, "they do not 



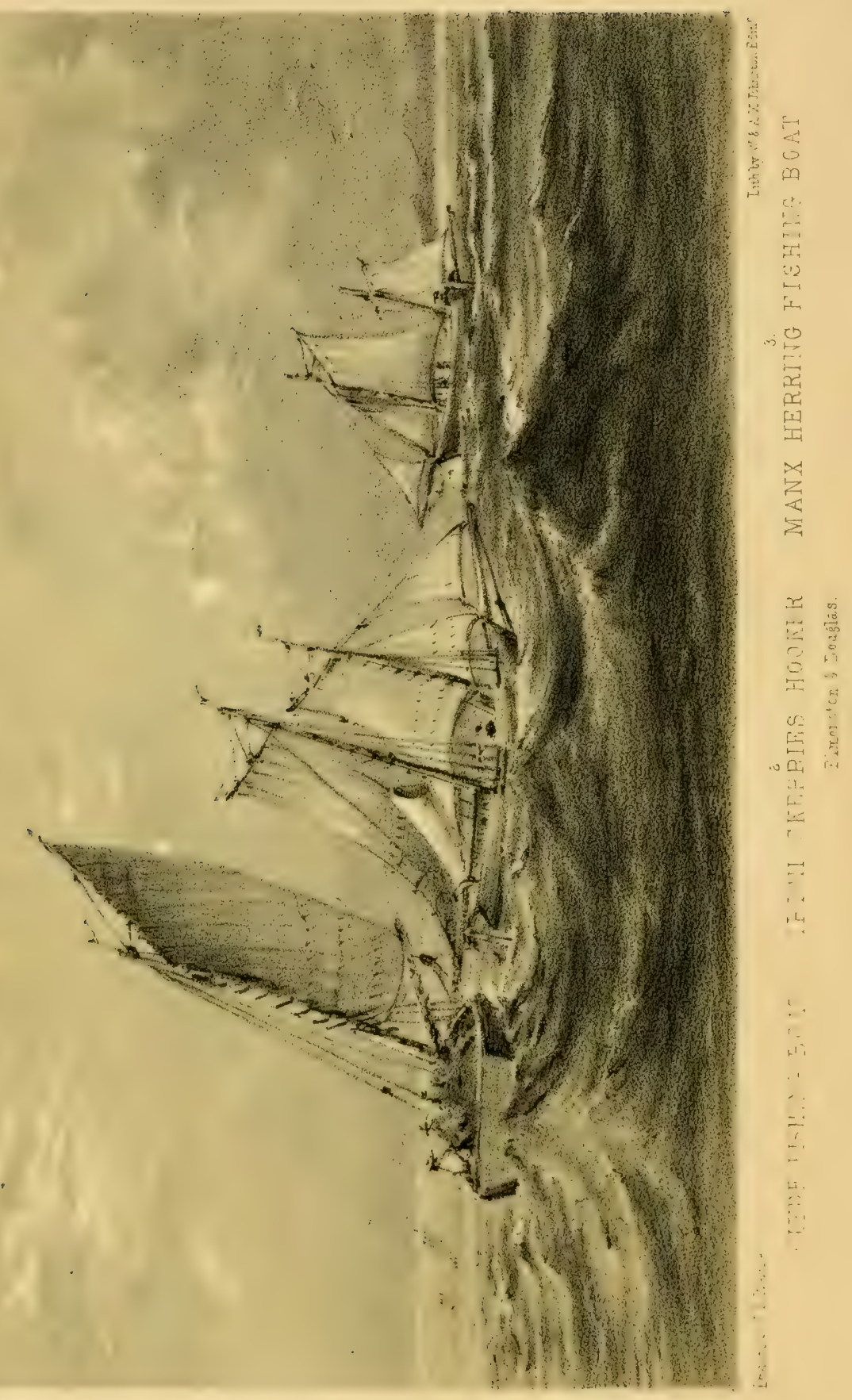


strike," and the fishing is therefore scanty. Anxious to make an experiment as to the effect of light in attracting them to the net, we went out with one of the fishermen's boats to the middle of the Firth of Forth, during the winter fishing, in the month of January, and used large lighted flambeaux after the nets were thrown out, and moved them in various directions round the boat in the course of the night; but the weather being intensely cold, the fish were searce, and, as the fishermen said, "did not rise," or rather remained quiescent below. At all events, the lights did not seem to be effectual in adding any great additional quantity to the take of the boat we were in, as compared with what was caught hy the other boats. It is worth stating, however, that such was the deceitful nature of the lights of the flambeaux in such a situation, that the fishermen in the boats at no very great distance were alarmed, and prepared to take up their nets, supposing that the lights indicated the approach of a steamer.

We have also witnessed the fishing in summer on the west coast and in the Highland lochs, where the herring's periodically appear. Here the risk and labour are far less to the fishermen, although the quantity taken is generally smaller. Surrounded by lofty hills, and sheltered in deep bays, the fisherman plies his pleasant calling in comparative ease and safety. We have been several times ont with the boats to witness the progress of the fishery, but excepting now and then seeing the waters at night shining with the phosphorescent light from the herring moving quietly along, or quiescent in the water, nothing otherwise indicated that herrings were near.

We have learned some important facts by accompanying 
the boats to sea in winter and summer, namely, that during the night the position of the herring in the water, or its distance from the surface, is much connected with the lightness and darkness of the night, and with the coldness and warmth of the atmosphere. In dark nights, and in mild weather, the herring swirns nearest the surface ; in moonlight, and in cold weather, it swims nearest the bottom. The experienced fisherman well knows and acts upon these facts; for, when the nights are dark or the weather mild, and the depth of the sea twelve or fourteen fathoms, the length of the buoy-rope, or the distance of the net from the surface of the sea, is only one to two fathoms; while in moonlight, or in frosty weather, the fisherman lets down the net from three to five fathoms, and finds that the greatest quantity of herrings are near the ground, to which the nets are allowed to descend; and it is known that the boats which proceed to fish the early herrings about twenty miles off Yarmouth, in May and June, have the top of the nets in dark nights nearly level with the surface of the water, as the surest method of taking the greatest quantity of herrings. It is also of importance to state, that the effects of winds seem to be very considerable on the visits of the herring, particularly in the winter. We have found it almost invariably to be the case in that season that the herring comes nearer our shores, and in greater abundance, when the wind blows for any length of time towards the coasts: for instance, if the wind in winter blows for some time from the west, the herrings are generally more abundant on the west coast than on the east coast, and vice versa.

The male herring has two milts of an oblong shape and whitish colour; and the female has two roes, which 
are darker than the milts; the number of eggs contained in a female was found by Dr Harmer (Phil. Trans. vol. Ivii. p. 280) to be 36,960 ; the weight of its body was $5 \mathrm{oz} .10 \mathrm{dr}$, , and the weight of the roe $480 \mathrm{gr}$. Herrings have been sometimes found with the roe of the preceding season in a bag, or covered with a skin, in addition to the roe of the following season. At Thurso, an inteligent fishcurer told me, that in the inside of a herring he found the old roe of the previous season, the eggs of full size, covered over with two layers of fat, and a thick dark film adhering closely to the back, and outside of this the two other parts fully formed about three inches in length.

After remaining on the coast for a certain number of weeks, the herring deposits its spawn on hard, clayey, or rocky ground, or gravel, before leaving the bays or estuaries where it resorts. The female first ejects the roe, which is afterwards impregnated by the ejection of the milt of the male. Sauer describes the mode of impregnation from actual observation, and states that in the inner harbour of St Peter and St Paul, Kamschatka, the herrings were extremely numerous; and he observed that on the 7th June the herrings made circles of about six feet in diameter, and in the middle of this circle, at the bottom, another, no doubt the female, was fixed; when the tide went out he saw the aquatic plants and the stones covered with the spawn, which was devoured by dogs, gulls, and crows.

We have fully ascertained that the shoals generally fix in one locality for depositation, and that immediately after spawning the herrings proceed to sea. The nets of the fishermen are then often covered with the detached unfecundated eggs of the female; but those eggs found loose in the nets are driven out by the pressure of the 
twine. The really oviparous fecundated spawn, of which we have specimens, is of a different description, and wonderfully manifests the sublime behests of creation. The proper incubation, as before mentioned, is as follows:The female remains quiescent at the bottom, the whole of the roe is at once deposited; the milt, thoroughly ripened in the male, has become changed from a solid mass to a liquid of the colour and consistency of cream; the roe, although placed in the bring flood, becomes a firm united mass, somewhat larger than, but similar in shape to, the roe in a full herring. This lifeless mass, or egg-bed, has the power of adhesion-it grasps firmly the stones, the rocks, the sea-weed, \&c. so much so, that we have found it rifficult to remove or separate it until the mass was dried or dead; the young being thus protected from the effects of storms and currents, to a certain extent from being devoured by fishes, and firmly fixed, probably, in a suitable feeding ground. Thereafter, the eyes are first observable; at least a small black speck is first scen in the egg. Then the head appears, and in fourteen days, or perhaps three weeks, the young are seen in great abundance near the shore, of a very small size; in six or seven weeks more they are observed to be about three inches in length, and move about in large shoals in winter and spring on the various coasts, and in the rivers and bays generally resorted to by the herring shoals, and it is likely that they attain to full size and maturity in about eighteen months. Lacepede says, that in North America the spawn of the herrings have been carried by the inhabitants and deposited at the mouth of a river which had never been frequented by that fish, and to which place the individual fishes from these spawn acquired a habitude, and returned each year, bring- 
ing with them probably a great many other individuals of the same species. It might perhaps add to our knowledge of the natural history of this animal if some of the proprietors of sea-water fish-ponds were to make experiments in the same way, by removing the spawn, or even by transporting the herring alive. The said author also states, that in Sweden thy have been transported alive to waters where they were awauting. But if the latter plan be attempted, great care must be taken to keep the bronchial opening shut in removing them from one water to the other, for herrings soon die in consequence of the drying of the bronchies. The summer herring spawns from the end of September to the begiming or middle of October ; the winter herring spawns in February and March.

Like other fishes of a similar form, the herring advances through the water by means of the tail, which is moved in rapid elastic flexures, somerwhat similar to the sculling of an oar; the other fins are evidently adapted. for steadying it in its progress, and for enabling it to rise and descend in the water, with the assistance of the air-bladder. When the herrings swim near the surface, if it is calm weather, the sound of their motion is distinctly heard at a small distance; and at night their motion, if rapid, causes a beautiful bright line, from the phosphorescent quality of the skin; and it is also saicl, that when a great body of them swims near the surface, their presence is ascertained by a strong fishy smell.

Light and heat appear to have also very considerable influence upon the motions of the herring; for instance, when the spring or summer has been unusually clear and warm, we have observed that the herrings do not come so near our coasts as they do in ordinary seasons. 
The cause may be, that a certain portion of light and heat is necessary for spawning, and in such weather they keep on the banks more distant from our shores, and in deeper water than in ordinary seasons. As a proof of this, the Dutch deep-sea fishermen are often successful in those years when ours are quite the reverse. At Lümfiord (at one time the greatest fishing station in Denmark, but now almost entirely deserted), where the entrance to the fiord or firth is narrow and the water shallow, the herring-fishing often completely failed when the summer light and heat were excessive; and the experienced fishermen there attributed this failure to that cause. In the Firth of Forth it is sometimes found that the herrings deposit their spawn on the grounds or banks between a mile or two to the westward of Queensferry and Inchkeith, being an extent of about ten miles; but many spawned herrings have been caught considerably to the westward of Queensferry, and in ordinary seasons shoals of herrings deposit their spawn on the clayey and rocky bottom between Inchkeith and the island of May. When the weather is clear and dry, in common seasons, the herrings keep at a distance from the nets, or at the bottom; but it has been often remarked by fishermen, that when the nets have been in the water for a considerable time at night, and the sky clear, few fishes came into them until the moon rose, when they have been almost instantaneously filled; so that, according to the song,

"The herring loves the merry moonlight."

On the coast of North America lights are frequently used, which are found of advantage in attracting the herrings to the nets. We have, however, tried lights at night on board of the open boats fishing herrings during 
the winter season in the Forth, but found no material advantage in so doing. A storm of wind or rain, succeeded by cloudy, calm, or hazy weather, and the wind blowing from the sea, are considered favourable by the fishermen. During the months of October, November, and December of 1833 , the winds continued to blow with little interruption from the west in strong gales, and the fishermen considered this the cause why there was no winter herring-fishing that season in the Forth; while the prevalence of the same wind on the west coast appeared to have furnished an abundant supply to the Clyde fishermen.

While on the subject of the appearance of the herring, it may be stated that we have known "the water telescope" to be used by the herring fishermen on the coast of Norway, which, when the surface of the water is muddy or obscured, penetrates several feet, and enables the fishermen more specelily or easily to discover the shoals; it is of a remarkably simple and cheap construction, and might be usefully employed for similar or other purposes on our coasts, lakes, and rivers. 


\section{CHAPTER IV.}

\section{ENEMIIES OF THE HERRING.}

The most destructive enemies of the lierring are unquestionably those which swim in the ocean. Although it has been often stated that the whale is extremely destructive of the herring, it is now known that the common or Greenland whale, Balcena mysticetus, as already stated, has been found not to prey on the herring, and that those varieties of the whale tribe which are known to feed on it frequent the Norwegian, Scottish, and Irish coasts. As to the Balcena mysticetus, or common whale, we are informed by the talented Scoresby, in his valuable book "On the Arctic Regions," that its food "consists of various species of Actinice, Sepice, Medusce, Cancri, and Helices, or at least some of these species are always to be seen wherever any tribe of whales is found stationary and feeding. In the dead animals, however, of the very few instances in which I have been enabled to open their stomachs, squillæe or shrimps were the only substances discovered." (Scoresby's Arctic Regions, vol. i. p. 469.)

And of this whale, he says, that it occurs most abundantly in the frozen seas of Grecnland and Davis' Straits, in the bays of Baffin and Irudson, in the sea on the southward of Belrring's Straits, and along some parts of the 
northern shores of Asia, and probably America. It is never met with in the German Ocean, and rarely within 200 leagues of the British coasts.

But in contradistinction to the common whale is the Balcena musculus of Linnæus, or Balcenoptera rorqual of Lacepede, which the same author says frequents the coasts of Scotland, Iceland, Norway, \&c., and is known to feed principally on herrings, thus proving that one of the most destructive enemies of the herring is an inlabitant of those coasts where the latter most commonly resorts. When in Norway making inquiries as to the natural history of the herring, I was assured by the Norwegians who engage in the herring fishery off the coast of that kingdom, that it is constantly seen where the herrings are generally fished, and is a good indicator of the best locality; and that the scene is quite lively with the great numbers of whales and aquatic birds which constantly attend any large shoal of herrings on that coast.

The Batana rostrata, or beaked whale, also frequents the Norwegian and adjacent seas, and is said to feed on herrings and other fish.

We are told by a Dutch author, that out of the stomach of a whale styled by him "Noortkaper," or North Caper, more than a barrel of herrings was taken; this whale had been stranded or captured at Shetland. "Van een gestrandene of gevangen Noortkaper omtrent Hetland, vertuald Frederick Martens in ziyn Groenland's Journal van den Jaare 1671, dat er meer dan en geheele ton haring in ziyn Maag gevonden wierd." (C. G. Zorgdrager's Bloyende opkomst der Aloude en Hedendagsche Grœnlandsche Vischery 1727, p. 118.)

Of the seal tribe there are various kinds which unquestionably prey upon the herring. 
Many also of the fish tribe may be named as known to be most destructive of the herring.

The cod (Gadus, L.), for instance, devours vast quantities; from the stomach of one we are told that fifteen full-sized herrings were taken. (Witness newspaper, 9th February 1850.) We have often found herrings in the stomach of this fish.

The whiting (Merlangus, L.) is also extremely destructive of the herring, much spawn, and large numbers of young herrings, having been often taken out of its stomach.

And it has been ascertained that even the salmon (Salmo salar), in the Moray Firtl, after spawning, has been caught with full-sized herrings in its stomach.

The most voracious of all the animals that swim is the dogfish (Squalus, L.). It is the terror of the fishermen.

Professor Valenciennes of Paris, in his edition of Cuvier's "Natural History of Fishes," p. 93, vol. xx., says "that the seamen of Dieppe have ceased to find herrings near Larron,-which, next to Caillebarde, was one of the best places for herrings in the English Channel,-in consequence of their having been destroyed by the dogfish; that the fishermen of Dieppe and Boulogne observe that the dogfish pursue the herrings principally during the day, and contend for their prey up to the very sides of the vessel; that they generally cut the herring in two before swallowing it, and the quantity of oil which arises in consequence covers the surface of the water to a considerable distance; and that it occurs often to the fishermen that they take up all the nets with nothing in them but herrings cut through the middle."

Our Scottish fishermen have made similar remarks as to 
the voracious habits of the dogfish on certain parts of our Scottish coasts; and owing to the destruction of the nets from its impetuosity, they avoid those localities where it is known to be most prevalent, however abundant the herrings may be.

The solan-goose or gannet (Sula Alba of Fleming) is in constant pursuit of the herring and other fishes, and darts with great velocity into the sea, seizing and swallowing them rapidly. We remember seeing the celebrated naturalist, Dr Neill, give six large herrings to one of these birds which he lept tame in his garden, and which it gulped over rapidly in succession. Mr James Wilson, brother of the late Professor Wilson, in his interesting and amusing "Tour round Scotland and the Isles," vol. ii. p. 106, says, when describing St Kilda, as to this bird, "Let us suppose that there are 200,000 solan-geese in the colony of St Kilda (we believe, from what we saw, the computation moderate), feeding there or thereabouts for seven months in the year. Let us also suppose that each devours (by itself or young) only five herrings a day, this amounts to one million; seven months (March to September) contain 214 days; by which if we multiply the above, the product is 214 millions of fish for the summer sustenance of a single species near the island of $\mathrm{St}$ Kilda."

And the gull (Lan'us, L.), cormorant (Pelicanus Carbo), and the divers (Colymbidce), all take their full share of the herrings, particularly when these are young.

ITan applies many means to add to the destruction of this useful fish. The most unwarrantable is the ground or beam trawl-net, which, if at all used on gravelly, hard, or rocky bottoms, must annililate vast shoals of herrings in a state of spawn; and, considering the quality of the fish 
taken by it, this instrument should be prohibited in certain localities at certain times.

Dredging for shell-fish may also be injurious in raking up the deposited spawn in certain places, and ought to be used with caution. At certain seasons the fishermen use nets with a small mesh, ostensibly to fish sprats, but in doing so a great many of the young herrings are taken, which must be pernicious to the herring fishery, and therefore ought to be carefully watched, and prevented when found to be destructive of the young fry.

The cruive or wicker-basket of a particular form, fixed in the tideway of some of our rivers and consts, takes often large quantities of herrings of all sizes; even clear unbaited hooks, also baited, and artificial flies, have often been used successfully at the beginning of the season in taking herrings.

The circular nets enclose vast numbers of herrings, and are often used.on the coast of Ireland, and these nets are of such size and strength on the coast of Norway that several thousand barrels have been taken in one net at one time in some of the bays and crecks in Norway.

Some very able papers have been written by Mr Cleghorn of Wick, to prove that the shoals of herrings on our ícottish coasts are diminishing in consequence of the great number of boats and nets employed on our coasts in fishing herrings ; but the reproductive nature of the herring is so great, that, if due care is taken not to disturb the spawn-ground by the above-mentioned destructive trawling for flat fish, or by other means to drive away the shoals, such as fishing during the day (as to which the Legislature should give full powers to those having authority), little fear need be entertained as to the future prospects of the herring fishery. 
We are also of opinion, that any operation which tends to disturb or scare the herring may drive away or diminish the shoals; such as leaving the nets loaded with herrings in the water when they are unable to be taken out in consequence of their weight, throwing the refuse into the sea after gutting the herring, as is done by the Dutch busses, or allowing the refuse of the oil of the herrings to go into the sea, as was done on the Swedish coast. 


\section{CHAPTER V.}

DESCRIPTION OF THE HERRING, IN ILLUSTRATION OF ITS NATURAL HISTORY.

Clupea. - On our coasts, of this genus there are the Clupea harengus, or Herring; Chupec pilchardus, Pilchard or Gipsy-herring; Chupea sprattus, Sprat-in Scotland, Garvie; and Clupea alba, or Whitebait.

The specific characters of the herring, as distinguishing it from the other fishes of the genus, are,-the dorsal or back fin is half-way between the point of the upper jaw and the end of the longest ray of the caudal or tail fin, and the ventral or belly fin is under the dorsal fin.

The Sprat is known from the young herring by having the belly serrated or supplied with bony points, in number thirty-three, and the ventral fins nearer the head. In the young herring the head falls off more in a straight line from the back, and the body is more flattened in the sides than that of the sprat; the full-grown sprat is also much broader and rounder in the belly than a young herring of the same length, and has the milt or roe formed in it at the spawning season, which the young herring of a similar size of course has not. 
The Pilchard and the herring are of a similar size, but the former differs from the latter by having the lack much thicker in proportion, with straighter linos on the back and belly; and if suspended by the dorsal fin, the pilchard hangs in equilibrium, while the herring is heavier by the head; it will be also seen that the scales of the pilchard are larger and fewer than those of the herring:

The Whitebait is of a lighter colour, las the belly more serrated, and its dorsal fin nearer the end of the tail; the head is one-fourth the length of the body, while in the young herring of the size of the whitebait, the head is one-fifth the length of the body; the body of the whitebait is also flatter.

Chupeid w.-There are three other fishes which belong to the 14th family Clupeida, and somewhat resemble the herring, but may be more easily known from it than the preceding; these are :-

The Anchovy (Engraulis encrasicolus).-This fish, besides being smaller than the full-grown lerring, has its lower jatw shorter than the upper, while in the herring the lower jaw is longer than the upper jaw.

The Twaite Shad (Alosa finta), called in Scotland the Rock Herring.-This fish grows to a much larger size thau the herring, and may be distinguished, in small specimens of the size of the herring, by the deep notch in the upper jaw, and by a row of four or six dark spots along each side, in a line with the upper part of the gill cover.

The Alice Shad (Alosa communis).-This sharl grows to a much larger size than the other, but has also the deep notch in the upper jaw, and one large dark spot on the upper part of the operculum, or gill-cover; it is named by the fishermen the Queen Herring, from its re- 
semblance to the herring, although it has sometimes been found to weigh eight pounds.

By noticing these characteristics the herring may be easily known from those fishes now mentioned; and we shall now proceed to describe the prominent and more interesting distinctions of the herring, without at the same time taking up too much space in minute details.

Description of the Herring.-The herring is a softfinned fish, of the bony or spinous class, liaving a mem. brane of eight rays covering the gills; a scaly carinated line along the belly, from the head to the tail, and the under jaw longer than the upper.

Head.-The head is about the fifth part of the entire length of the body-which is without scales-is almost flat on the top, and slightly bent towards the nose, the under jaw projecting beyond the upper jaw.

Eyes.-The eyes are placed on the sides of the head, about the middle of its length, the iris being of a silverywhite colour, and the pupil black; they are slightly oval, and are furnished with double eyelids.

T'ongue.-The tongue, although short, is distinctly formed, and of a whitish colour; some of the teeth, as mentioned hereafter, are placed on the lingual or tongueplate.

Ears. - It has no external organs of hearing, but a fringed orifice appears bolow the eye, on the inner side of that part of the head which covers the gills, which is probably that organ. The fishermen affirm that they hear; and state that when a noise is made in the boat, the peculiar sound they make when swimming on the surface ceases. And we are told that in former times the churchbell of St Monance in Fife, which hung upon a tree 
in the churchyard near the shore, was not used, but removed every year, during the herring season, because they believed that the fish would be scared away from the coast by its noise. (Chambers' Picture of Scotland, p. 210.)

Nose. - The nose of the herring has a considerable cavity behind the two nostrils, which are separated from each other by a very small and almost imperceptible film, but the whole exhibits the most perfect, although minute, adjustment of details.

Teeth.-There are, almost unseen, a few teeth in the upper jaw, four rows in the tongue, a few in the upper portion of the mouth and at the throat, and on the lower jaw four or five small teeth on each side.

Gills.-The herring has four gills or branchix on each side, each being supported by an arched cartilage. There are besides tro small imperfect gills not having any arch; these join the gill-lid, apparently to regulate its motions. The convex side of the gills is supplied with fringed fleshy fibres of a red colour when the fish is in a healthy state; the concave side, or that nearest the mouth, is furnished with long serrated spines.

Fins.-The fins are seven in number, namely, one dorsal of eighteen rays, two ventrals of nine rays each, one anal of seventeen rays, two pectorals of eighteen rays each, and the tail or caudal-fin of eighteen rays. But the number of rays varies; we have sometimes counted, dorsal seventeen, anal fourteen to seventeen, pectoral fifteen to eighteen, and caudal eighteen to twenty; the ventral fin we have always found to contain nine rays.

Scales. - When fresh from the sea, the scales have at first a clear lustrous golden or orange colour of consider- 
able beauty; they afterwards appear of a silvery tinge. They lie over each other in regular lines, with the convex edges pointing from the head towards the tail, so that they form small segments or concave edges towards the head, forming fifteen rows of scales between the dorsal and the ventral fin. Professor Valenciennes, in his edition of Baron Cuvier's "Natural History of Fishes," vol. xx. p. 27, says, "The scales detach so easily that it is very rare to find a herring which has not lost them almost entirely." Now, it will be found that the scales of the herring are more attached, or are less deciduous, than those of any other fish of this gemus, as indeed may be seen in the properly cured, salted, or smoked herrings.

Bones.-The spine or back-bone consists of fifty-six vertebre ; the cavity of the belly, terminating at the anal fin, has on each side thirty-five or thirty-six bones or ribs, and the sides near the tail are furnished with several minute bones, terminatiug in soft elastic branches at that fin.

Colour.-The herring, when taken out of the water, is one of the most beautiful of the scaly tribe, exhibiting on the sides and back brilliant golden and blue tints, and having to a considerable extent the bright pavonine lustre. After it has remained a short time out of its element, it becomes of a dark-bluish and green colour on the back, and of a silvery colour on the sides and belly; the termination of the body at the tail is remarkable in exhibiting a beautiful dark-green colour when held before the light.

Heart.-The heart of the herring is situated at the upper part of the stomach, in a cavity near the gills; it is three-sided, and consists of a single auricle and a 
single ventricle. From the ventricle proceeds an artery extending to and connected by minute branches with the gills.

Esophagres.-The œesophagus or gullet is remarkably short in proportion to the size of the fish.

Stomach.-The stomach is thin and membranous, and capable of great distension; the gut is nearly of uniform size throughout its length.

Gall-bladder:-The gall-bladder is small, the bag of a dark-green, and the liquid of a light claret colour, having a sweetish and somewhat pungent taste.

A ir-bag. - The vesica natatoria, or air-bag, is round, of a silvery-white colour, nearly the length of the stomach, and pointed and narrow at both ends; it is connected with the posterior part of the stomach (which posterior part is shaped like a funnel) by a duct which lies in the female between the roes, and in the male between the milts.

Size.-The full-grown herring visiting the British coasts varies from eight to twelve inches in length; those caught to the north of Shetland are in some instances larger; and the winter herrings fished on the coast of Norway in January and February are sometimes from thirteen to fifteen inches in length. The following are the sizes of the herring from different localities :- 


\begin{tabular}{|c|c|c|c|}
\hline & $\begin{array}{l}\text { West Coast } \\
\text { of Britain. }\end{array}$ & Ireland. & $\begin{array}{l}\text { East Coast } \\
\text { of Britain. }\end{array}$ \\
\hline 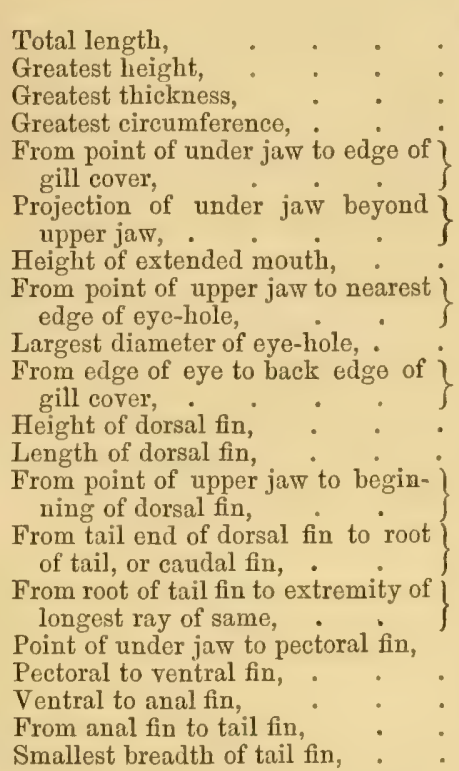 & \begin{tabular}{|c|} 
Aug. $26,1856$. \\
$9 \frac{1}{2}$ \\
$2 \frac{1}{4}$ \\
$1 \frac{1}{2}$ \\
$5 \frac{1}{2}$ \\
$1 \frac{7}{8}$ \\
$\frac{1}{8}$ \\
1 \\
$\frac{5}{8}$ \\
$\frac{3}{8}$ \\
$\frac{7}{8}$ \\
$\frac{15}{18}$ \\
$\frac{1}{1} \frac{8}{0}$ \\
$3 \frac{7}{8}$ \\
$2 \frac{7}{8}$
\end{tabular} & $\begin{array}{c}\text { Sept. } 1857 . \\
10 \\
2 \frac{1}{4} \\
1 \frac{1}{4} \\
5 \frac{1}{3} \\
2\end{array}$ & $\begin{array}{c}\text { July } 27,1857 . \\
10 \frac{1}{2} \\
2 \frac{1}{2} \\
1 \frac{1}{4} \\
5 \frac{3}{4} \\
2\end{array}$ \\
\hline
\end{tabular}

As some authors state that the female herring is larger than the male, we give the following tables to prove that this is an error. They show the length of the herrings, and the number of milt, roe, and spawned herrings.

Sixteen Herrings taken from the Firth of Forth near Aberclour, on $3 d$ February.

\begin{tabular}{|c|c|c|c|}
\hline Length. & Number. & Milt. & Ton. \\
\hline 9 & 1 & 1 & 0 \\
91 & 3 & 1 & 2 \\
$9 \frac{1}{2}$ & 11 & 7 & 4 \\
$9 \frac{3}{4}$ & 1 & 0 & 1 \\
\cline { 2 - 3 } & 16 & 9 & 7 \\
\hline
\end{tabular}


IN ILLUSTRATION TO ITS NATURAL HISTORY.

Eleven Herrings from off Newhaven, 22d Dec.

\begin{tabular}{|c|c|c|c|}
\hline Length. & Number. & Milt. & Roe. \\
\hline $10 \frac{1}{2}$ & 4 & 2 & 2 \\
9 & 7 & 2 & 5 \\
\hline & 11 & 4 & 7 \\
\hline
\end{tabular}

Twelve Herrings from near Inchkeith, 7th Felmary.

\begin{tabular}{|c|c|c|c|}
\hline Length. & Number. & Milt. & Roe. \\
\hline 12 & 1 & 1 & 0 \\
$11 \frac{1}{2}$ & 1 & 1 & 0 \\
$10 \frac{1}{2}$ & 3 & 1 & 2 \\
$10 \frac{1}{4}$ & 2 & 0 & 2 \\
10 & 4 & 0 & 4 \\
$9 \frac{1}{2}$ & 1 & 1 & 0 \\
\hline & 12 & 4 & 8 \\
\hline
\end{tabular}




\section{CHAPTER VT.}

THE FOOD OF THE HERRING.

The usual food of the herring consists of the small medusæ, the Oniscus marinus, small crustacea, small fishes and other food of various kinds, as will be detailed in the following remarks on this subject. On some parts of the Norway coast they eat a small crustacea called the roé-aat (Astacus), which, it is said, renders the fish not very suitable for curing. Ilerrings very often leap at flies, and they are frequently caught by hooks baited for the purpose of catching other small fishes, and even by clear unbaited hooks. A herring-curer of Banff told us that one scason, early in the month of June, he canght several herrings having young sand-eels (Ammodytes tobianus) in their stomachs; and in one of them lie found no less than fortytwo, from one to two inches in length. This was an early period for herrings appearing in the Moray Firth, and the milt and roe were of small size. A fisherman at Fraserburgh observed one year in August that the stomachs of many of the herrings were full of young fishes, and found seventy of them in one herring. On July 24th, we examined the stomachs of several herrings caught off Dunbar. Those which had the milt and roe small had their stomachs filled with young sand-eels, about two inches in length; while, on the contrary, those in which 
the milt and roe were full grown had none. Again, on the 9th of July of another year, we examined several herrings fished some miles from the shore off Dunbar: the herrings had the milt and roe small, and many had their stomachs full of young sand-eels of two or three inches in length. In another year, on the $2 \mathrm{~d}$ September, we again examined several herrings from off Dunbar, the milt and roe being large in some, while others were spawned, and in the stomachs of these were portions of the spawned milt and roe. About the end of May, on another occasion, an enterprising fish-curer there, wishing to get herrings early to the Hamburg market, sent boats with rods and fly hooks to a distance of about a mile and a half from the shore, where, in the course of an hour, the crew of each boat got from 300 to 500 herrings; there were tweuty-seven hooks on each line, and there were generally seventeen or eighteen herrings on the hooks each-dip. One year, in the end of May, two or three young lads at Banff caught each upwards of six dozen of herrings in a few hours with fishing-rods and fly-hooks; the herrings were of good size, and of the usual kind. On the 21st July, some years since, some Fifeshire boats tried the fishing about one mile to the westward of the Island of May, with plain clear white-tinned hooks. They soon got about 500 herrings into each boat. At the same time one boat tried with six nets, and fished 3000 herrings. From May to July, sorne years since, there was a very considerable take of herrings in the Moray Firth by means of the fly, and also with clear unbaited liooks. One year, on the 9th May, the herring-fishing commenced in this way at Eyemouth and the adjoining coast, aud was very successful. Several boats went off immediately after sunset with lines and hooks unbaited, and in the 
morning returned generally with from 2000 to 3000 herrings.

It will here be useful or interesting to give the opinions of some of the most eminent naturalists on this hitherto doubtful subject.

Lacepede says, The food to which its quality is owing; consists commonly of the eggs of fishes, small crabs, and worms, "La nourriture ì laquelle il doit ses qualités consiste communément en œufs de poissons, en petits crabes et en vers." (Lacepede, vol. v.)

Scoresby says, "These (the herriugs) subsist on the smailer cancri, meduse, and animalcules." (Account of the Arctic Regions, vol. i. p. 546.)

Mr MI'Kenzie, in his Essay on the Herring; published in the second volume of the IFighland and Agricultural Society's Trausactions, 1808, in mentioning that herrings are sometimes taken by unbaited hooks, says (p. 314), "It secms certain, therefore, that the herrings take these hooks for such animalcules as they at least sometimes feed on."

Rondeletius says, "The herrings feed largely on the sea-caterpillar."

And another author says, "Their food is insects" (Sharou Turner's Sacred History, pp. 317-18), meaning, of course, small crustacea.

Neucrantz, an author who wrote an able work, "De Harengu," and who died in 1671, states, "that he had frequently ascertained the nature of the food from personal observation, and had counted in one herring upwards of sixty minute squille or shrimps, and that when the spawning was complete, there was less food found in the stomach of the spawned herring:" (Neucrantz de Harengu, p. 28.)

Leuweuhock, who minutely examined the stomach of 
the herring, came to the conclusion that they fed, "not only on animalcula, minute fishes or aselli, minute crustacea, squille, and even on their own ova, but also, when pressed for hunger, anything they meet with." "Abqui ita milhi conspicua fuit haleces non tantum vesci exiguis pisciculis atque etiam propriis ovis, sed et quocunque obvium urgente necessitate versus stomachum demittere." (Leuwenhoc7;, I. Epist. 97, 1p. 52, 53, dated Jauuary 1696.)

Otho Frederick Mïller, in his work published at Copenlagen and Leipsic; in 1785, on Crustacen, describes the Cyclops longicomis as having been found by Gueruer "in sinu Drobactiorum," in the stomach of the herring.

The roé-aat described as a red worm by some authors, is stated in Sonnini's "Buffon," to be one of the crustacea, the Astacus harengum, already mentioned, which gives a reddish colour to the stomach of the herring. (Somnini's Buffon, vol. Ixvii. p. 15.)

Fabricus, who wrote a work, "De Specie Insectarum," in 1781, says of the same A stacus harengum, "Habitat in oceano Norwegico copiosissime, harengum et gadaram esca" (vol. i. p. 511), namely, that it is most abundant in the Norwegian seas, and is eaten by the herring and cod; and he also describes another of the minute shrimps, Gammarus, as existing in the Norwegian Sea, and that it is "lharengum cibus gratissimus," most agreeable food to the herring (vol. i. p. 518).

In an elaborate work prepared by a gentleman already referred to, W. von Wright, chief of the Civil Department at Stockholm, and published by order of the King of Sweden in $18 \pm 3$, "On the Herring and the Causes of its Scarcity on the Swodish Coasts," we find that he says, "In all the herrings I opened, amounting to a very con- 
siderable number, I found more or less distinct remains of entomostraca and other crustacea. Sometimes the stomach was found completely filled with them, and sometimes I found along with these the remains of young fishes. I must also observe that I generally found the greatest quantity of food in the young herrings; and the least in those having large milts and roes. From this circumstance, along with the fact that the herring is very lean after spawning, I have concluded that the full herrings do not come to the coasts on our shores for the purpose of seeking food, but for the purpose of spawning. (Handlinger rörande Sillfisket, p. 132.)

Professor Valenciennes, in his edition of Cuvier's " $\mathrm{Na}$ tural History of Fishes," states, that he has found in the stomach of the herring the fry or young of fishes of the size of a pin, and considered that some of them were the young of its own species; and from his own experience, and the information he has obtained, he is satisfied that, like other similar fishes, it eats the various animals of a suitable description that come in its way (a sa portee). (Vol. xx, p. 70.)

Cloquet, in the "Dictionnaire des Sciences Naturelles," says of the herring, "Il se nourrit des œufs de poissons, de petits crabes et des vers ;" namely, they live on the eggs of fishes, small crabs, and worms (vol. i. p. 428).

Bose, in the Nouveau Dictionnaire d'Histoire Naturelle, says of herrings: "Ils vivent de petits poissons, de petits crustaces, de vers marines, et de mollusques,"-they live on small fish, small crustacea, sea-worms, and testacea.

Dr Neill, in his "List of Fishes," published in the "Wernerian Transactions" in 1811, says, that he found "in the stomach and œsophagus of a large female herring no fewer than five young herrings-not sprats." 
There having been much controversy on the subject of the food of the herring, we have thought it right, not merely to make the most careful examination, but also to obtain the best authorities. And we may here state that the celebrated Agassiz, in a conversation we had with him at the first meeting of the British Association at Edinburgh, said, that from the form of its mouth and teeth he considered that its food must be of a more varied sort than generally supposed.

It is therefore evident that the herring does not confine itself to one particular kind of food, as has been maintained, but that it feeds upon crustacea-the young of other fishes, its own young, ovæ, worms, and flies. 


\section{CHAPTER VII.}

PERIODICAL VISITS OF THE HERRING.

Is attempting to give a statement of the periodical visits of the herring to the Scottish and other coasts, and to describe, as far as may be possible, its size and quality, we shall commence with Shetland, and proceed westward round to the Solway Firth, and then return to Cape Wrath, and take the east coast to Berwick, which will of course include the whole coast of Scotlaud, and then describe its visits to the coasts of those countries where their visits have been ascertained. To avoid repetition, we shall classify the size of the herrings by the number to a barrel; for instance, 600 is the sixth class, 800 the eighth class, and so on.

SCOTLAND.

Shetrand.-The winds and weather seem to liave more influence on the herring-fishery on the Shetland coasts than on that of any other quarter, which may he accounted for by their exposed situation; and until a comparatively recent period the fisling of herrings by the native boats was merely subsidiary or secondary to the cod and ling fishing.

There is generally a large description of herring caught at the extreme north of the Shetland Islands near Unst, Fetlar, and Yell. 'They may be fished in the heginning of 
June, but the boats are often later in proceeding to the fishery. When the herrings are deficient on the north or cast side, they are often abundant on the west or south side; and when few herrings can be fished at Yell, Unst, or Fetlar, considerable quantities are fished off Levenwick, Sandsair, Aithsvoe, Lerwick, and Bressay on the east side. This may be accounted for by the prevalence of the easterly or westerly winds. The greatest quantities are caught in July, August, and September. The herrings taken on the east side are generally two-thirds "full fish" and one-third "spent fish," while fully more than one-half of those caught in September are spent fish.

The herrings caught on the north-west of Hillswick, Papa, and Vaila, are similar to those of the east side, although not quite so large.

The herrings on the west side, particularly in the bay or firth between Fitful Head and Skeldness, are quite different from the herrings fished on the east side, being similar in size to the Lochfine herrings. About one-fifth of those fished are full herrings; rather more than a fifth are matjes, and these may be considered equal in quality, as well as size, to the Lochfine herrings; and rather less than three-fifths are spent-herrings, or rather have not their ovaries developed, but do not appear to have recently deposited their spawn. In size, those of the north and east of Shetland belong to the fifth and sixth elass, and those of the west to the seventh or eighth class.

OrKneys-TVest side.-Shoals of small herrings, of about the winth or tenth class, appear from the widdle of May to the middle of July, about ten miles from the land, between Costa Ifead, north, and the entrance of the Pentland Firth, south. These horrings resemble those fished off Thurso; the ovaries are hardly developed, and their 
stomachs are frequently found to fee filled with young sand-eel, or other small fish.

North-East Coast.-A superior description of herring, hoth as to size and quality, appears off the north-east coast about the 25th July, between Sanda and Stronsay, and the fishing continues upon the east side (with occasional intermissions) until about the middle of September; these herrings are about the sixth and seventh class; and at first in the shoals there is about an equal proportion of matjes and full and spent-herrings; but by the end of the fishing nearly all those fished are spent herrings.

The West Sea, or South Isles, is not, as the name might imply, on the west side, but the fishing is in the sea or bays between Siouth Ronaldshay and Longhope. There is here often an abundant fisling, lut the herrings are generally spent fish, or liave deposited their spawn; the duantity is often very large.

Carthess-Thurso.- Small herrings of a particularly fat or cily description appear off 'Thurso, sometimes as carly as . Iay. Those fished early may be ahout the ninth class; they are rich in flavour, but are not well adapted for curing, or suitable to lie preserved for longer than a few weeks. This kind is usually succeerled by a larger description of excellent herrings, which, not being so vily, are more suitalle for curing. The quantity that comes upon this coast in June and July is often considerable.

Nortir and West Coast. - Along the coasts of Sutlierland, Inverness, and Argyle shires, including the various islands of these counties, herrings usually appear in great shoals in summer, and frequeritly in wirter; they are caught in some places in the North- West II ighlands as early as the beginning of June, and even in May, but the usnal time of their conoing in shoals moon the coast and into the 
lochs is the months of July, August, and September. The winter herrings generally appear in November, and continue on the coast till the middle of January, and in some localities later. Although no particular loch can be pointed out where their appearance every year is certain, yet Loch Eribol in Sutherlandshire; Loch Inver, Loch Kennard, Great Loch Broom, Little Loch Broom, Loch Ewe, and Loch Torridon in Ross-shire ; and Loch Urn, Loch Moidart, and Loch Kintra in Inverness-shire; and Loch Linnhé, and Loch Craignish in Argyleshire, are frequently well supplied. The time of their resori to any particular loch in any particular month or year cannot be predicted by any one. A writer well versed in the subject says, "The continuance of a shoal in any loch contiguous to the Minch for eight days together is uncertain. It often lappens, that after a very successful fishing for three or four nights in the lochs along that line of coast, the herrings retire so suddenly to the Minch that not a vestige of them is to be found in a loch or bay for many weeks." ("Nackenzie's Essay," High. and Agric. Soc. Trans., vol. ii. p. 319). Another writer states, "That the Great Minch (the sea which separates the Long Island from the mainland), from the middle of June till the end of September, is often crowded with herrings of the best quality."

NoRth-West IIIgHLANds-Lewis Islands.-The her-

* As a remarkable circumstance connected with the herring, it is worth recording, that in March 1817 young herrings of about three inches in length fell in a shower near the ferry of Shien, Argyleshire; another shower, but of full-sized good herrings, fell near Melford House, in the same county, in 1821; and on the 9th February 1830, a number of small herrings, some of them alive, fell on the island of Alva, Argyleshire. In the last instance, the day was calm, with a steady even-down pour of rain, and the distance from the nearest part of the seashore fully half a mile. The conclusion is, that they must have been projected by waterspouts.-Caledonian Mercury, April 1, 1830. 
rings of the North-West Higlhlands are generally of medium size, and excellent quality, although there have been different sizes observed at different periods, and in different lochs. It has been often observed that the herrings in the Minch, and on the east side of the Long Island, are smaller than, but much superior in quality to, those coming upon the coast and into the lochs of the west side from the Atlantic. At Stornoway the fishing now begins generally on the 20 th of May, and the Act prevents fishing before this on the west coast; and the localities where the herrings are found are extremely variable, and embrace the Minch, the Broad Bay, the Back of the Lewis, and circumjacent coasts. These herrings canght in MIay are fat and oily, like the first-caught Thurso herrings, and the scales more deciduous than those of any other of the herrings caught on the coasts of Scotland, and belong to the seventh and eighth classes. As the scason advances, this description of herring is succeeded by a superior kind, both as to quality and size, the size being between the sixth and seventh class; but some of the inferior kind are found among the new shoals.

Loch Roag is a very considerable lake, or arm of the sea, in Lewis Island, about twelve miles in length; it is so open that the waves from the Atlantic, in western gales, flow into it with great impetuosity; but there are a number of small islands which afford shelter, and behind which there is safe anchorage. Before the middle of the eighteenth century, this Loch was well known for its herrings, they being considered of good quality. About 1750 the herrings left it, and scem not to have returned until about 1790, when, for a series of years thereafter, there was a very regular fishing during the months of November, Decomber, and January. In 1797, the her- 
rings discontinued their visits; but after the lapse of thirty-two years, they returned in the autumn of 1829 in considerable quantities; and in late years the fishing lias been frequently abundant. (Stat. Account of Scotland, vol. xix. p. 252 ; Edin. Phil. Journal, No. xv., 1830).

We may here state that in 1710 Lewis Island was the general resort of boats from the most distant parts of Scotland; and in that year we find that the small town of Easter Anstruther sent as many as thirty boats to the fishing at Lewis. (Sir Robert Sibbald's Hist. of Fife, p. 338.)

Loch Un.-A remarkable peculiarity has frequently been observed in the size of the herrings of this loch, they being much smaller than those caught in Loch Duich and on the neighbouring coasts, although Loch Um is only a few miles westward; being sometimes as small as class twelve, while the general size of the North-West Highland herrings may range from the sixth to the eighth class. Loch Urn appears to have been often visited by large shoals. One year such great quantities appeared as to fill the whole loch from the narrows to the bay-head; and such a quantity ran on shore that the beach, for four miles round the head, was covered from six to eightecn inches in depth, and even the ground under water, as far as it could be seen at low-water. At a subsequent period another shoal came into Loch Urn, and a similar quantity was left on the beach by the receding tide; but the great borly soon after left the loch, although as many were left behind as to afford good fishing for several weeks.

Loch Broom. - The quantity of herrings caught in the North-West Highlands varies much, not only on account of the uncertainty of their visits, but also from the desultory and irregular manner in which the fishery is gencrally prosecuted. The fishing in Loch Broom, for 
several years back and until lately, has been very inconsiderable, although formerly in this loch, which is not much more than seven miles in length and half a mile in breadth, several hundred vessels have, in a course of successive years, got full cargoes of excellent herrings. In the latter part of the year 1857 and the beginning of 1858, there were large shoals of herrings in this loch, sufficient to supply cargoes of full-sized herrings to a great number of sloops from various parts of Scotland. Three hundred boats were occupied in the fishing from about the middle of October until the middle of January; and on the 11th of February upwards of twenty crans or barrels were taken in the yair at the upper part of the loch, although the gateway of the yair was open, and allowed egress to the fish.

Loch Torridon.-Here they have often been very abundant. One year the boats of twenty-five vessels, eacli vessel having two or three boats, besides a great many country boats, were often twice loaded in a night. When - they do appear, the herrings generally continue two months, and give enployment to 5000 or 6000 persons.

Loch Carron is about a league in length, in some places above a mile in breadth, and from four to sixty fathoms in depth. The herrings here one year were so plentiful that the boats were for five weeks fully laden every night; and "it was indifferent to the fishers in what part of it to shoot their nets, or what length to give their buoy-strings."

Caroy Loch, in the Isle of Skye.- They were one year here so abundant, that, shooting night or day, the nets were always filled; and similar shoals of herrings continued to visit the coast many years in succession.

Loch Slapan is also in the Isle of Skye; and here one 
year there were 400 vessels, which fished about 96,000 barrels in one season.

Harris.-In December 1837, an immense shoal of herrings, of a large size, set into the lochs on the western coast of Harris. One shoal entered a creek in the Sound of Harris, the mouth of which dries at half-tide, while the depth within the bar is seven fathoms; and about 200 crans were caught in this pool alone. (Edinburgh Weekly Chronicle, 16th December 1837.)

Firth of Clyde-Arran.-Off the west end of this island, and in the adjacent Sound, there is generally a good fishing from July to the end of November.

Loch Fyne-Loch Long.-Herrings are annually caught, but not in considerable quantities, in Loch Fyne and Loch Long, beginning in the month of June; and they sometimes appear in abundance in the river Clyde. Experienced fishermen say that herrings may be caught in Loch Fyne all the year through. In corroboration, to a certain extent, of this remark, it may be stated, that in the beginning of January 1832 the herring fishery was very successful in Loch Fyne, the boats having been generally well filled, and the herrings of good quality. In December 1835 Loch Fyne was visited by a most extraordinary shoal of herrings. They made their appearance in some of the bays in such prodigious quantities that the usual method of fishing was departed from, and nets of every description were stretched across the bays, and enclosed all the fish until the receding of the tide, when they were left high and dry upon the beach; and two boats engaged in this fishing caught each from 20 to 25 maizes (500 to the maize) each night. (Edinburgh Observer, 1st December 1837.)

The herrings of Loch Fyne and neighbourhood have 
been justly celebrated for their superior quality: they have a whiter colour, a plumper shape than, and a much superior flavour to those caught on the Berwickshire coast; and, with all these good qualities, they keep well when properly cured. The general size of this kind of herring may be reckoned as ranging from the sixth to the eighth class, the later the season the nearer the larger size; but there are sometimes herrings of a very large size-even of twelve and thirteen inches in lengthcaught there. The quantity of herrings fished in Loch Fyne and adjacent places of late years has been rather on the decrease; but it is not easy to ascertain this accurately, from the great number that is sold fresh, of which no account is kept. A portion of the herrings fished there have been, for many years back, exported to the West Indies, - a circumstance of which Lacepede did not seem to be aware, as he says in his work that the exportation of herrings to warmer climates had never been attempted.

Ayrshive Coast.-They are frequently found near the Ayrshire coast in June and July, and they have even been caught in considerable quantities off Irvine and Troon so early as the month of May.

Solway Finth.-Herrings of small size, but good quality, generally appear here in considerable quantities, and are taken principally upon the Scottish side in the Solway Firth. The usual fishing time is about the month of September.

IsLE OF MLAN.-The herrings caught on the west coast of the Isle of Man are generally of medium size and good quality. They come sometimes upon the coast as early as Jume, but the principal fisling time is ahout the begimning of September. The herrings fished on the west 
side of Man are much superior to those taken at the eastern or Douglas fishery; the first resembles the Loch Fyne herrings, but of the latter a considerable part consists of spawned fish.

East Coast-Cape Wrath.-Returning to the cast coast of Scotland, as before proposed, we find herrings appear there very regularly, and generally in considerable quantitics. They are caught from June till August and September in the sea embracing the Moray Firth from Cape Wrath to Inverness, including the east coasts of Sutherlandshire, Caithness-shire, and Ross-shire.

Wick:-Although at the beginuing of the season an inferior size of herring similar to those caught at Thurso is obtained off this coast, yet the herrings generally caught are of good size and excellent quality-being about the seventh to the eighth class. This extensive fishery legins about the middle of July and ends in September.

Helmsdale, dec.-Farther along the Caithness coast, and in the neighbourhood of IIelmsdale, the herrings average about the sixth or seventh class; at Lossiemouth they are generally similar to those caught at Wick; but at the upper end of the Moray Firth they have frequently been found of a very small size, not exceeding the tenth or twelfth class.

Banffi, \&c.-From Inverness, along the south side of the Moray Firth, including Morayshire, Banffshire, and part of Aberdeenshire, herrings are caught about the same time as on the north side; the quality is also similar to those caught at Wick, and they are also of a good medium size. They appear upon the coast in June, but are at first so small that the nets camnot catch them, but they begiu to be of a sufficient size in July, and in August they are full-sized, and come nearer the shore. 
Cromarty.-From 1690 to 1709 a very extensive fishery was carried on at Cromarty, whither the herrings annually resorted in considerable abundance. Shortly after the Union (1707), an immense shoal was thrown, or rather ran themselves, on shore, in a little bay to the east of the town. The beach was covered with them to the depth of several feet, and salt and casks failed the packers. The residue was carried away for manure by farmers in the neighbourhood. Strange to say, however, they left the Firth in a single night, and no shoals again made their appearance for more than half a century. In 1780 a body of herrings was seen swimming up the Firth with all the accompaniments of a large shoal-whales, porpoises, and gulls; they passed through the roadstead and the strait opposite Invergordon, beating the water for several miles into a foam, and giving it the appearance it presents when ruffled by those sudden land-squalls which blacken the surface. The shoal took up its spawningground opposite Ardilly, a villa within three miles of Dingwall, and was fished in immense quantities within 400 yards of the shore. The following year a similar body returned and rested for some time in the bays of Fortrose and Campbeltown, and then turned down the Firth after affording an abundant fishing. Shoals of herrings have since occasionally returned to the upper part of the Firth. One season, in the beginning of autumn, the Bay of Cromarty appeared as if its countless waves were embodied into fish and birds. No fewer than seven whales, some of them apparently sixty feet in length, were seen within the short space of half a mile. When they spouted, the jets seemed, in the rays of the noonday sun, as if speckled with silver, occasioned by the small fishes which they drew in with the water and thus ejected. 
I am indebted for the above information to a very talented and graphic description of the Moray Frith herringfishery, written by the author of "Poems, by a Journeyman Mason"-the celebrated IIugh Miller. From 1816 to 1820 their visits were more regular, and the fishery successful. After this period there was a falling off; but in 1841 the fishery was an abundant one, and in 1855 nearly 400 boats were well filled every night from the 1st to the 5th September.

Fraserburgh.-Along the coast from Banff to Fraser. burgh, herrings are generally caught of similar quality, and about the same time. The shoals off Fraserburgh are often very large. In the latter part of the month of August 1816 the herrings came in close to the shore, and for some days the fishing-boats were loaded with herrings of the finest quality; and from Kinnaird-Head the shoal were seen to be pursued by a numerous body of whales, amounting to about 100, accompanied by great numbers of sea-fowl.

Off Buchanness they generally appear in great abundance every year. The Dutch fishermen, who often get here their greatest supply, begin fishing here about the 1st of July.

Aberdecn.-A successful herring-fishery was commenced in 1836 off the coast at Aberdeen, and herrings are caught of superior quality, as early as the middle of July; since then generally every year. They appear on various parts of the coasts from thence to the Tay about the same time; but those got near the shore are larger and of a coarser quality than the herrings of the Moray Frith and neighhourhood, for they are generally as large as the sixth class.

Tay.-Formerly in the Tay, for several years succes- 
sively, herrings appeared in abundance, a good winter fishing having existed opposite Balmerino and Woodhaven; but of late years the quantity caught there has been very inconsiderable. They are similar in quality to the Forth herrings. (Sibbald's History of Fife ; Note by Ed. of new edition, p. 414).

Off the Tay and Forth, a few miles distant from the coast, the Dutch fishermen sometimes get considerable quantities of excellent herrings in July and August ; these are of medium size, or about the seventh class. This fishing must have been very considerable, and known and followed by the Scotch in 1710. Sir Robert Sibbald says, "Crail has eighty fishing-boats, which, for the most part, are employed in herring-fishing, which come upon the coasts yearly about Lammas, at which season there come from the coasts of Angus, Mearns, and Aberdeenshire, about 200 boats more, which the inllabitants of this town furnish with nets and other materials for the herring-fishery." (History of Fife, p. 346.)

Frith of Forth.-While the entrance or lower part of the Frith of Forth is visited by shoals of herrings every winter, higher up it is also visited by other shoals of herrings, but (if we should judge from the quantity taken) in much greater abundance in some years than others.

Previous to 1793, the mouth of this Frith, between the Island of May and the Fifeshire coast, was resorted to by a great many fishermen, who caught considerable quantities of lean and shotten fish in February and March, which herrings are now supposed to have been those returning from the higher part of the Frith after spawning. It is remarkable that the visits of the herring higher up the Forth were not known till 1793, the winter fishing 
having first commenced in that year. The discovery was previously made by a poor man, residing at Donibristle, of the name of Thomas Brown, while fishing small haddocks; he concealed the discovery as long as possible, while he supplied his own wants by the simple means of dipping pails or buckets into the sea at such places and scasons as he found most suitable; it is also said, that, twenty years before that year, a seaman having let his sail fall overboard in Inverkeithing Bay, brought several herrings into the boat within its folds, and although he told several fishermen residing near the spot, none of them could be tempted to make a trial. (Sir Robert Sibbald's History of Fife, p. 306.) Some fishermen at Queensferry were at last, in 1793, induced to commence, and their great success encouraged others. Since then the fishing has been amnually resorted to by boats and vessels from various quarters; several hundred boats have in some years come from the west coast of Scotland, and even from Ireland, Wales, and the Isle of Man, to this fishery. For several years lately, however, the fishing has not been very abundant, and it latterly has been confined to the fishermen of the Forth and immediate neighbourhood. These herrings are every year of a uniform size and shape, from the eighth to the ninth class; they are of a good quality for curing, being not fat, and are excellently adapted for the West India market, and for red herrings. The fishing commences sometimes in the month of November, but often not till January, and generally lasts till February or March, the time that they are generally observed to spawn. It is seen every year that the herrings always spawn before they return to the sea.

Eyemouth, Dunbar, and from the mouth of the Forth to Berwick.-Considerable shoals of herrings appear here 
every year; and although they do not set in close to the coast till about the month of August, yet the fleet of Dutch herring busses, when it meets with a contrary wind, which prevents their proceeding farther north, gets a consilerable fishing about twenty miles off that coast in the end of June and beginning of July. But the herrings caught by our own fishermen close in-shore in August and September are often ripe for spawning. They appear on this coast suddenly in great shoals, and the great quantity caught in the meshes frequently sinks the nets, which are sometimes left a night or even two nights in the water, according as the weather may suit for getting them into the boats. Such herrings, if salted and barrelled, must tend greatly to injure the character of the herrings caught on this coast. Although great quantities are frequently fished here, the fishing generally lasts only a few days. They are of large size, or about the sixth class in ordinary seasons.

\section{ENGLAND.}

Northumberland. - Herrings appear in August and September from Berwick, southward, on the Northum berland coast; they are similar to the herrings caught off Dunbar, and the fishery is often considerable. North Sunderland is the principal station in this quarter.

Yorkshire.-At Staithes, Runswick, and Robin Hood's Bay, they are caught from the latter part of July to the latter part of September, and of late years have been fished in considerable quantities.

Norfolk:-The herring-fishery off Yarmouth is the most important on the const of England; 500 deckerl vessels may be seen at this fishing at one time, of which about 



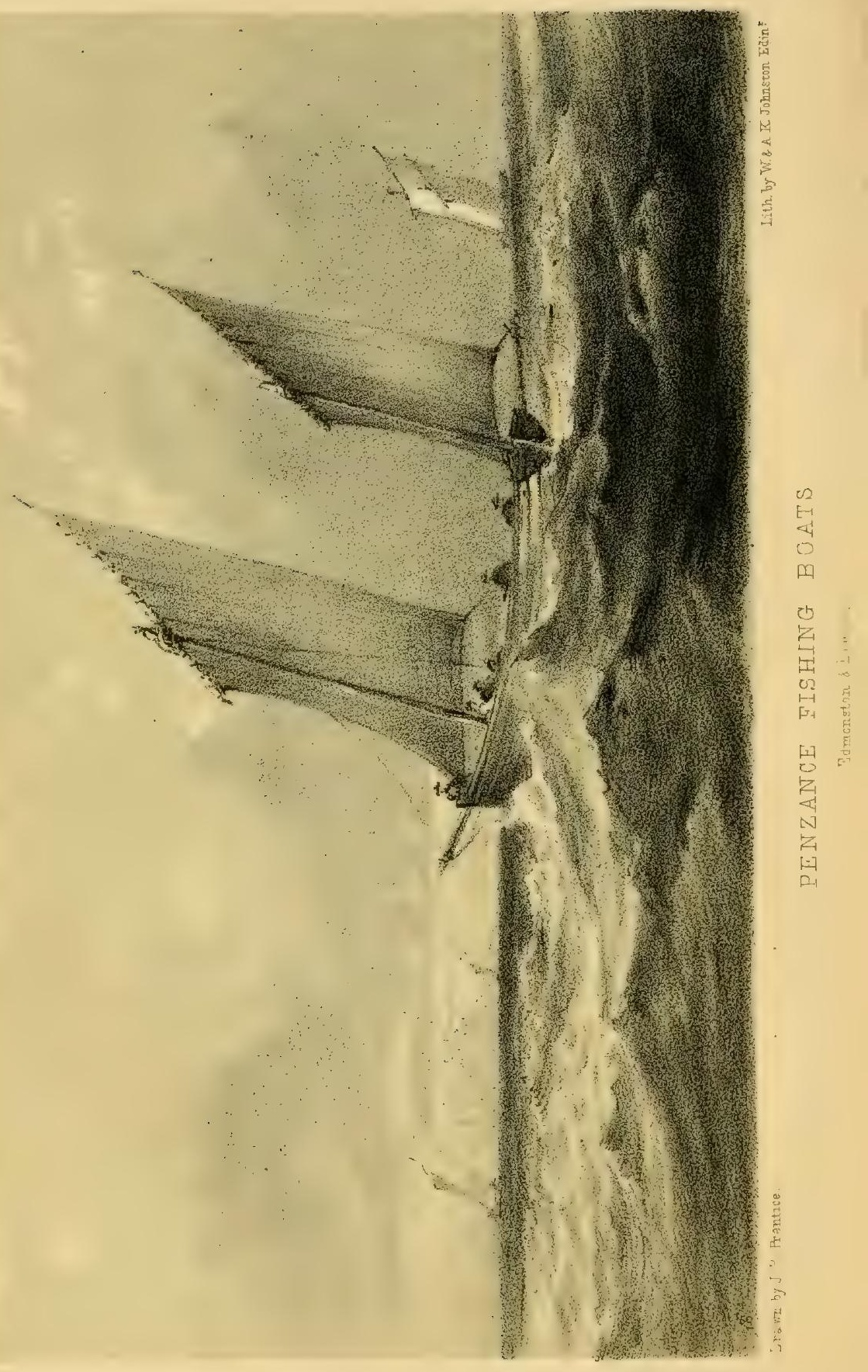


100 belong to Yarmouth, and 70 to Lowestoffe. The herrings are of a smaller size than those fished on the Northumberland coast; in several years lately considerable quantities of good herrings have been fished off this coast in June and July, but the principal fishery commences in October, and continues for about two months. Great numbers of foreigners fish at this locality, the most numerous being Dutch and Freuch. The herrings are found to be smallest near the coast, and the boats, therefore, proceed half-sea over, as the largest herrings are preferred for smoking; the whole, or nearly the whole, of the herrings brought to Yarmouth, not sold fresh, being smoked. The boats proceed from north to south as the season advances.

Kent.-The shoals of herrings off Folkestone are in some years very considerable ; they commence fishing in the beginning of October, and continue to the end of November.

Sussex.-The fishory of this coast is principally carried on by the Hastings boats; they begin fishing in November and continue until the end of December, and the supply obtained at the fishery is often very considerable.

Cornuall.-Herrings are caught on the coast of Cornwall in August and September, but not now in any great quantity. The pilchard fishery seems to be the most abundant at present; but, about twelve years since, herrings in considerable quantities were taken near St Ives, and but few pilchards. The Penzance and Cornish fishermen are celebrated for the superiority of their fishing-boats and materials; they visit at the proper seasons the herring-fisheries at the Isle of Man and on the coast of Ireland. 
3. IRELAND.

The coasts of Ireland are generally visited by large shoals of herrings. Their most regular visits are on the Atlantic side of the island; but it must be observed that in some of the localities the fishery is not prosecuted with success, which may be considered as owing to the want of means rather than to the absence of herrings.

At Killybegs the herrings may be caught generally in abundance from the end of December to the beginning of March. They are small, and may be of the size of the eighth class, and boats to the number of 700 to 800 often attend this fishery, not only from the immediate neighbourhood, but various parts of the island, and even sometimes from the Isle of Man and Cardigan.

West COAST-Kitleries, \&c.-The coast and bays south to Galway are sometimes in the winter visited by shoals of herrings, which appear in abundance one season in one loch or bay, and sometimes in another season in other lochs or bays. They are fished in Greatman's Bay, at Costello, Roundstone, near Slynehead, at Ballinakill, and Killeries; and in some seasons the herrings may be caught in twenty different bays at the same time. But their visiting any particular bay is uncertain; for instance, there was no fishing at Roundstone from 1827 to 1833 . On this coast, hesides the winter fishing, appearances strongly indicate that a successful fishery may be carried on on the extensive line of coast from Sheephaven Bay to Broadhaven Bay from May to October.

Galway.-The herring-fishery at Galway is, like the Killyluegs fishery, more certain and regular than at some of 
the other localities, and affords employment and food to a very great number of people, so many as 200 boats being often employed at one time at this fishery. The Claddagh fishermen, forming a great proportion of these, are a peculiar race of men, inhabiting one quarter of the town of Galway; they are a hardy and industrious race, and have laws among themselves regarding the fishery. They make it a rule not to begin fishing till the 4th of Septem. ber, nor until all the Claddagh boats are ready to proceed to the fishery; and it is their custom, when ready, to apply to the clergymen of the West Convent Chapel in Claddagh, one of whom proceeds with them to the fishery the day they begin, and offers up a prayer for an abundant fishing. It is said that they formerly, before beginning, buried a cat on the beach, with the view of procuring a successful fishing. The harvest fishing is pretty abundant in the creeks and bays from Galway south to the Clare coast. So many as $85,000,000$ herrings have been cured in one season in Galway, almost entirely in bulk.

Kerry.-Off Seafield herrings visit the coasts from the middle of January to March. They are larger than, and inferior to, the Galway herrings. At the mouth of the Shannon they may be caught from the beginning of July to November.

Dingle Bay.-Here the herring shoals sometimes continue from July to December.

Valentia.-Near this place the take of herrings is often very considerable, from the circumstance of the fishermen using deep-sea seines (which will be described elsewhere). One of these nets has been known to take as many as 80,000 to 100,000 herrings at one haul.

South Const-Kenmare.-Herrings are caught at Ken- 
mare, county Kerry, from July to October, but at Bantry there has been no productive fishery since 1828. The season lasts from August to Christmas.

EAST CoAst-A\%low.-Onward to Arklow herrings appear at different localities from August to December. At Arklow the fishing was formerly cousiderable from June to August, but now it begins about the 1st of October. The Arklow herrings are similar in size to the Loch Fyne herrings. On the Wicklow coast there are sometimes considerable shoals from September to Christmas, and until within these few years there was a summer fishing in June and July.

Carlingford.-At the Lough of Carlingford the herrings were at one time fished abundantly, but the Irish Channel herring-fishery is now considered the most advantageous; it lasts from June to Novcmber; and the fishing is pursued less or more by the fishermen at Newcastle, Dundrum Bay, \&c.

Ardylass is a very considerable herring station. About 100 Penzance boats (of from 15 to 20 tons), 100 boats from the Isle of Man, and 100 Irish boats, used annually to pursue this fishery.

Carrickfergas. - The visits of the herring shoals are generally very regular at different parts of this coast, from Ardglass to Carrickfergus, from June to November ; and herrings in considerable shoals are said to enter Belfast Lough to spawn in September and October.

Larne and Fairleced.- Herrings may be caught from May to September of superior quality in different localities between Larne and Fairliead, but not in considerable quantities.

North Coast-Lough Fugle, \&c.-From Lough Foyle to Lough Swilly there are two herring seasons, namely, 
in July and August, and again from the middle of November to the beginning of February.

As is the case everywhere, the harvest herrings are larger and finer than the winter herrings.

Lough Swilly-Farland Point.-From Lough Swilly to Farland Point the herrings may be caught from July to November, and from Christmas to March.

Rutland.-Near this herrings were so abundant about thirty years ago, that 500 vessels were generally laden iu a season from November to January; these were of superior quality and of the sixth class, while the Killibegs herriugs at that time were of the eighth class; in 1836 herrings appeared here in great abundance.

-Teiling.-It is said that in the months of April, May, July, and August, from Teiling to Malinhead, there are large shoals of herrings; but they are not fished, because it is supposed it would be difficult to cure them.

We have thus made a circuit of the whole Irish coast; and it must be evident that a most abundant and certain supply of herrings, and which might afford food and employment to a numerous population, is to be found on the coast of the county. Down, and on the coasts and in the creeks and bays between Galway and Torry Island.

\section{WHITE SEA.}

Herrings are abundant in the White Sca, Kola heing one of the principal fishing stations. They are fisher twice a-year, namely, in the month of April,- the herrings caught at this season being small and lean; and secondly, from the beginning of August till the end of September,-these are much better herrings, heing 
larger and fatter. It is said that herrings may bo fished in this season in almost any part of the White Sea.

\section{ICELAND.}

Herrings sometimes appear at Iceland, but seldom in any considerable body; the quality is generally inferior. The principal places of their resort are Westmanœ and near Oxefield on the south-east coast, but their visits are irregular. Horrebow, in lis History of Iceland (chap. 1v. p. 75), says " the herrings do not resort to the coast every year." A shoal appeared at the first-named place in July 1835 , and the usual time of their appearance at Iceland is July and August. They are generally full of milt and roe, and of medium size. Olaus Olavius, in his History of Iccland, says, "But as herrings are not seen there but now and then, and have not been caught but in the year 1773 , it is supposed that there cannot be any considerable quantity." Meu da silden ikke sees der, uden nogen enkelte gange, og er ikke bleven fanget uden i aaret 1773, saa formode nogle at dens mængde ei maae vare betydelig. (Olaus Olavius, vol, i. p. 104.)

\section{FAROE.}

Herrings are seldom seen at Faroe in any considerable shoals, although small quantities are now and then fished by the inhabitants. They appear to be of the eighth class.

7. NORWAY.

Drontheim.-They appear on the coast off Drontheim and neighbourhood in shoals about the middle of June, 
and continue upon the coast till November. These are generally of the eighth class and of good quality. A larger sized and coarser herring appears on the same coast in December, and they continue till the end of February. They are as large as the fifth and sixth class.

Bergen.-Farther south and near Bergen, the large description of herrings approach the shore in January, and continue during February and March. These are also of the larger size and of coarser quality than those caught off Shetland; and the smaller sized, or fat or summer herrings, of the eighth class, are often fished near the coast in June and July.

Stadtland.-The Norwegians have also a considerable fishing off Stadtland, where they generally get very large herrings, few being under a foot, and many thirteen inches in length. This kind is what is generally sent in great quantities by the Norwegians to the Baltic for sale, and is inferior to Scottish herrings.

Lofoden.-The summer herring-fishery off Lofoden and the coast of Helgeland (Norway) was formerly very considerable, but they have not come upon this coast for the last twenty years. (Bloms Reisebeskrivelse $i$ Nordlandene, 166).

Flekiefiord.-A consideruble fishery of the Norway herrings existed for several years near Flekkefiord in Norway. They were fished about four miles from the shore, and from 200 to 300 vessels, averaging about 50 tons, got full cargoes, the fishing commencing generally in Jamuary, and continuing about three weeks. This fishery was considerable in the beginning of 1836 , but has totally failed since.

Christiansŭnd.-Off Christiansŭnd and along the adjacent coasts a very superior description of herring is 
caught in summer, of about the eighth or ninth class, of which considerable quantities are sometimes exported to the Baltic.

\section{SWEDEN.}

Bohus, Gottenburgh, de.-Very few herrings are now caught on the Swedish coasts. The Swedes attribute their departure, as already mentioned, to the firing of British and other ships of war attending convoys, \&c. Some idea may be formed of the extent of the fishing there from the quantity exported. In the six years from 1775 to 1781 , they exported annually, on an average, 122,217 barrels, while the average annual quantity exported in three years from Scotland was then only 32,629 harrels. The fishing of lierrings, to any extent, first commenced near Gothenburg in 1752 ; but the fishing almost entirely ceased in 1808 , and since then the herrings are generally caught among the rocky islands, and few or none out at sea; the quantity that now appears there is inconsiderable.

Stronstadt.-The fishing extended along the coast from Gothenburg to Stromstadt, a distance of about 105 miles. 'They were caught in the first years in July and August, but in the later years not till November. The Swedish herrings were generally of good quality, and about the size of the seventh class.

\section{DENMARK.}

Elsinore-From Elsinore upwards to Falsterbo, herrings of small size are caught from September till Christmas, but not in such quantities as in former times. 
Liimfiord.-The lest herring-fishery in Deumark was at Lïmfiord, on the east coast of Jutland. They were fished twice a-year, the one fishery begimning in February, if the ice was melted, and it continued in March and April for the spring season; and the other in November and December in winter; the latter caught herrings were always the fattest, smallest, and best. The quantity caught in a year was very considerable, perhaps about 200,000 barrels in both seasons. They came up the Lïmfiord full of spawn, and spawned there each season. The entrance of the river leading to Lümfiord does not. exceed 360 feet in breadth, and there is there a comparatively shallow sandbank, the water being generally clear, and the bottom a fime sand. It was observed by the fishermen there, that the stronger the winds blew up, that frith, the more herrings were caught. These herrings were of small size, from the winth to the tenth class, and generally of good quality; but in consequence of the sea breaking through to the lake or frith on the west coast of Jutland, the herring-fishery has been destroyed, as the herrings liave almost entirely disappeared, and the town of Aalborg, on the east side, at the original entrance of Lümfiord, has suffered very much in consequence of the loss of this important fishery. This loch may be now termed an estuary, and, therefore, Denmark has one more island added to the numerous list. It is possible the herrings may return; but if they do not, the mere circumstance of the sea making an entrance on the opposite coast-and that as yet to a very moderate extent-being the cause of driving the herrings from this their usual haunt, is a curious occurrence in the natural listory of this fish.

Great Belt.-In the Great Bolt herrings are caught 
from the middle of September till December, and they are full of young, and generally of fair quality. There is frequently also a summer fishing, which lasts till June.

Kiel.-From the Belt upwards to Kicl herrings of similar quality are caught, and about the same time.

\section{BALTIC.}

Wismar.-At Wismar herrings of ordinary quality, and about the eighth class, are caught with the seine in February and March, but not in any considerable quantity.

Bornholm.-About 2000 barrels of medium size are caught annually by the inhabitants of the Island of Bornholm in July and August.

Pomerania.-Higher up the coast, embracing Pomerania, a smaller herring is caught from the beginning of February until April; they may be about the twelfth class. In May, soon after the departure of this kind, a great abundance of small-sized herring (called stromting) sets in upon the coast, and continues until the end of June. They are so small as to require 2000 to a barrel.

Rugen.-Farther up that side of the Baltic, from Rugen to Dantzic, herrings appear in small quantities from September till Christmas, and they are as large as the eighth class; they also set in upon the same coast from February till May.

Riga.-Near Riga some herrings are caught of similar quality to the preceding.

Biornberg.-Near Biomberg, in the Gulf of Bothnia, herrings of small size are caught in March, April, and May, but not in considerable quantities, and they are 
generally used fresh. Herrings do not appear in any great quantity higher up the coast.

\section{HANSE TOWNS.}

Hamburg.-Up to the year 1822 herrings were caught in considerable quantitios off the Elbe, near Cuxhaven, from November to March. The quality was inferior. They have now disappeared, or are never fished, and we do not find any fishery of consequence till we come to the kingdom of the Netherlands.

\section{HOLLAND.}

Zuyder Zee.-In the Zuyder Zee, off Harlingen and Philipina, abundance of lean or shotten herrings often appear in November or December.

Texel.-Above the Texel full herrings are caught frequently at the same period, and a considerable fishery is carried on every year between the Dutch and the English coasts, as far south as the North and South Foreland, till the 1st of January.

\section{FRANCE.}

The Channel-Calais, \&c.-The visits of the herrings on the French coast generally take place from autumn to January; and although the fishery is often inconsiderable, they are caught sometimes in large quantities off Calais, Dieppe, Treport, and on the coasts as far as the mouth of the Loire; but beyond this point no shoals have been at any time found. The size is about the seventh class. 


\section{ASIA.}

Bluck Sea.-IIerrings of about the eighth class visit the Asiatic coasts of the Black Sea, and are eaught in considerable quantities from the middle of October to the end of March. They are of superior quality, and slightly differ from the herrings of the north in the teeth ani form of the head.

Caspian Sea.-This sea is plentifully supplied with very fine herrings, and an extensive fishery is carried on at Bakoe, on that coast; and the quality is so highly prized, that the herring is called by the Persians the royal fish; the fishery is generally most abundant in July. (IIon. G. Keppel's Persian Narrative, vol. ii. p. 204.)

Okolsk.-In July and August shoals of herrings annually appear in the Gulf of Okotsk in Russian Tartary.

Kamtschallac.-On the east coast of Kamtschatka they arrive in April, and remain till June and July. (Tuckey's Maritime Geography, pp. 276, 286.)

Bay of Avatska.-They appear in great shoals in the Bay of Avatska towards the latter end of April, and remain till the beginning of June. They seem to come in shoals in botli spring and autumn, there being a considerable difference in the size, the spring fish being largest. (Billing's Expectition to the Northern Regions, pp. 75, 89, 298, 299.)

Kovema.-In lat. $69^{\circ} 28^{\prime}$, long. $168^{\circ} 28^{\prime}$, in the Icy S'ea, 300 herrings were caught by the seine on the 16th July; the water was fresh enough to dress victuals. They ascend the Kovema in great shoals in September; they are split and dried by the natives. 
15. BEHRING'S STRAITS.

Kotzebue Sound--Herrings are caught in Kotzebue Sound, above Behring's Straits, by the American Esquimaux, in July, and in Graintley Harbour, long. 174, lat. $65^{\circ}$, in September. (Beechey's Voyages.)

\section{BATHURST INLET.}

Captain Franklin states that several herrings were caught in the nets set by his people in Bathurst Inlet, on the 5th August, in lat. $66^{\circ} 30^{\prime} \mathrm{N}$., long. $107^{\circ} 53^{\prime} \mathrm{W}$. A pretty extended description of these herrings was compared with the herrings brought to the London market in January, and found to agree exactly; they appeared to be mätjes, the roe or milt having been small. (Franklin's Journey to the Polar Seas, p. 377, and App. p. 717).

Sandy Bay.-At Sandy Bay they are caught in October; these herrings slightly differ in the teeth and form from those of Europe.

\section{AMIERICA. - UNITED STATES.}

Carolina.-In the month of January they come upon the coasts of Carolina, and are said to proceed northward.

Virginia.-They visit the coast of Virginia in February, and all the bays and rivers as far north as the Bay of Fundy; and they continue spawning till the month of May, and in soure places may be caught till July. (American Trans., vol. ii. p. 237). 


\section{NOVA SCOTIA.}

A small and very fat variety of herring approach the shores of Nova Scotia from the Bay of Fundy in the month of May, and about the end of May enter Aunapolis Basin, and on the shore of Clements are caught in cunsiderable quantities. These are generally smoked and packed in boxes containing about 200; so many as 100,000 boxes have been exported of this kind in one season.

South Coast.-Another herring of a large size, and full of spawn, arrive on the south coast of Nova Scotia in May; but they are lean and not much esteemed, although taken in considerable quantities.

West Coast. - In Chedebucto Bay, and particularly in Crow Harbour and near Fox Island, a considerable fishery takes place in the months of autumn; these herrings are caught both by the usual herring-nets and by the seine. These are of good size and of excellent quality, and, with the mackerel fishing, give employment to a great number of the inhabitants. (M'Gregor's British America, vol. ii. pp. 171, 172.)

It ought to be here remarlied, that the quautity of herrings visiting any locality is generally thought to be indicated by the number caught; this is by no means always a just mode of judging. The fishermen, as before mentioned, trust too much to the appearance of water-fowl, the larger fishes, \&c.; and although there may be great abundance of herrings in one place, they may be misled by these appearances, and go to another place, where the 
sole circumstance of a few sickly herrings swimming near the surface takes them from the proper fishing-ground; but much depends upon the nets and activity of the individual fishermen.

From the preceding account it will be observed that there are two kinds of herrings,- - one that visits the coasts in summer and the other in winter,-but we cannot find that marked difference which entitles us to give the characteristics of a new species to the herrings of either season; we therefore venture to doubt the propriety of that able author, Yarrell, giving the name of Clupea Leachii to the herring described by him; and since writing this remark we find that Professor Valenciennes agrees with us on this point. (Baron Cuvier's Hist. Nat. des Poissons, edited by Valenciennes, vol. xx. p. 175.) 


\section{CHAPTER VIII.}

\section{MIGRATION.*}

Various accounts have been given of the visits of the herring upon our coasts. Many writers have stated, and some scientific works still state, that the herring comes from the Arctic Circle, in large shoals of some leagues' extent, dividing into lesser shoals on coming towards the north of Scotland-one body proceeding to the west coast of Scotland and to Ireland, and another to the east coast, each directing its course southward. Others state, that although the herrings do not come from the Arctic Circle, they at least come from a considerable distance northward of Scotland. But we consider that the herrings inhabit the seas adjacent to the coasts, bays, or rivers where they resort for the purpose of spawning; and that after sparwning they return to sea in the neighbourhood, where they continue, and where they feed until the spawning season again approaches, while the fry, on being vivified, continues near the spawning-ground until it is of sufficient size. This is the most rational conclusion, and the following are our reasons for this opinion :-

1. We find every ycar, at a certain period of the year, a particular size of herring always resorting to the same

* Read at the Zoological Section of the British Association meeting for the Promotion of Science held at Manchester in 1861. 
place; for example, the size of the herrings caught off the projecting coast of Stadtland in Norway is much larger than the size of those caught on the west coast of Shetland; which kind, again, is nearly twice as large as the first-caught Thurso herrings; and these are smaller than the Isle of Man, Minch, and Loch Fyne herrings, smaller than the Caithness and Banff herrings, and much smaller than the herrings caught off Aberdeenshire, Fifeshire, and Berwickshire. Again, the Yarmouth herrings are smaller than those of Aberdeenshire and Berwickshire, and in the West Highland lochs the size of the herrings in such loch is distinctly seen and known; for instance, in some of the Highland lochs, for years, large quantities have been caught, uniformly of the size of the tenth class, while in other lochs the size is uniformly of the seventh or eighth class.

A size of herrings similar to those of Yarmouth till lately visited Lümfiord in Denmark, and still visits the coasts of that country. Now, on the Mecklenburg coast in the Baltic, the size of the herrings is larger than those of Denmark; and proceeding up the Baltic coast above Mecklenburg, namely, on the Pomeranian and part of the Prussian coasts, the herrings are fully one-third smaller; and again, still farther up, they are larger, and about the size of the Moray Frith herrings. Thus those who argue that the herrings come from the north must furnish two kinds of herrings, -namely, one kind which, in its progress, grows smaller on its journey, and another which grows larger. Even in the English Channel the varicties may be easily distinguished in the neighbouring localities; for instance, Professor Valenciennes in his edition of Cuvior's "Natural History of Fishes," says, "It is not difficult, with a little practice, to discover the dif- 
ference which exists between the herrings fished near Calais and those fished near Dieppe; those fished near Calais have the body longer and more flat and compressed on the sides than those of Dieppe, which are rounder and shorter" (vol. xx. p. 47).

2. As to quality, nothing so much proclaims the error of the tale of their all coming from the north as the general state of the herring. For instance, as already mentioned, those caught off Shetland are not nearly so fat as those caught about the same time on the coast from Thurso to Lach Broom. In the first of the seasun those caught in Loch Fyne are not so extremely fat as the Thurso herrings; and the herrings of Loch Fyne are superior in quality to those of the east coast. Again, there is a marked difference in appearance and ruality (and this is easily distinguisher loy those accustomed to see them) between those caught near Caithness and Morayshire, and those caught off Aberdeenshire and Berwickshire. The quality of the Danish and Baltic herrings is inferior to the Moray Frith and West Highland herrings; and those caught on the coast of Holland are so inferior as not to be pickled at all by the Dutch. The Yarmouth herrings are inferior in some respects to those of the north of Scotland; and the herrings got on the French coasts are also of inferior quality.

3. As to the time of appearance, we find much to prove that the herrings are natives of the seas adjoining the coasts on which they spawn. As a few instances, it may be stated as well knowu, that herrings are caught in Loch Fyne before any are caught near Cape Wrath; and off Derwichshire and Aberdeenshire by the Dutch before any are canght off Caithness; and even off Yarmouth herrines have been caught in May. We find they are not generally 
caught on the Atlantic side so early as on the east coast of Scotland; and the various times of their approaching the coasts in the Baltic prove the fixity of their places of resort.

4. No well-authenticated instance has been given of the herrings having been seen approaching the south in a high northern latitude. Indeed, although we have conversed with intelligent masters of the Dutch herring: busses, we could not find any one who ever saw any considerable shoal on the northern part of their fishing: grounds; and none of the seamen of our Greenland whale ships ever saw any of those shoals of the magnitude so fabulously described proceeding southwards ; and Scoresby made the same statement to ourselves,-namely, that he had not, in his many voyages, ever seen any shoals of herrings proceeding southwards.

5. No shoals of herrings have ever been ascertained to exist in the Greenland seas, and no herrings have ever been found in the stomachs of the whales caught there. The food of the Balcena mysticetus, or common whale, consists of Actiniæ, Sepiæ, Medusæ, Cancri, and Helices. The Narwal inhabits the seas near Spitzbergen, but remains of Sepir only were found in the stomachs of several examined by Scoresby. The Trichecus rosmarus (Walrus or Sea-horse) inhabits the icy seas adjacent to Spitzbergen; in the stomachs of those examined only shrimps (Crangon vulgaris), craw-fish (Palinu'us vulgaris), and young seals (Phocce) were found. Of other marine animals examined by him, Scoresby says the Alca arctica (Auk or Puffin) feeds principally on shrimps and a small species of helix; of the Alca alva (Little Auk), that it also feeds on shrimps; of the Colymbus Gylte (Guillimot), it feeds on shrimps and small fishes; of the 
Squalus boreales (Greenland Shark), he says, "A fish resembling a whiting was found in the stomach of one that I killed." Captain Phipps only caught the Sucker (Cyclopteris viperus), and the Coal fish (Gadus carbonarius), and no herrings, when fishing near Spitzbergen. Moreover, Scoresby, in his list of "Fishes found in the Aretic Regions," does not include herrings (Arctic Regions, vol. i. p. 540). Egede, who resided fifteen years in Greenland, after enumerating various kinds of fish caught there, says, "No herrings are to be seen" (Natural History of Greenland).

6. We find that those species of whales which feed principally on herrings frequent our own shores and those of Norway. Scoresby says of the Batona musculus, "This species of whale frequents the coasts of Scotland, Ireland, Norway, \&c., and is said principally to feed on herrings" (Voyage, vol. i. p. 482) ; and the Batcena rostrata inhabits principally the Norwegian seas.

7. Bloch, the celebrated naturalist (with whom Lacepede in this particular statement coincides), has established that fishes of a similar size, even in fresh water, could not make, from spring till autumn, the long voyage attributed to the herring.

8. The same naturalist further states, that "herrings may be found in certain localities all the year through," and this coincides with the opinion of the experienced fishermen at Loch Fyne and other places; and it is well ascertained that herrings, either young or old, may be caught in the Forth any month in the year.

9. The herrings mentioned as coming from the north are never known to return, or even to proceed southward, but when proceeding to some coast for the purpose of spawning. 
10. And we also may ask, "Why the smallest herrings proceed to certain places in the Baltic, and the larger to the North Sea?" and as it is asserted that the whales are the cause of their flying south, why do we not see the whale on every coast every year? Mr Yarrell, in his valuable work on fishes, truly says: "There can be no doubt that the herring inhabits the deep water all round our coast, and only approaches the shore for the purpose of depositing its spawn within the immediate influence of the two principal agents in vivification, increased temperature and oxygen; and as soon as that essential operation is effected, the shoals that haunt our coast disappear, but individuals are to be found, and many are caught throughout the year" (vol. ii. p. 112).

11. Various other fishes have similar habits in spawning. The salmon ascends rivers from the sea at particular periods for the purpose of spawning. The sprat appears in shoals, in various localities of the coasts of the British islands, from November to March. The shad or alosa is found in shoals in some of our rivers from May to July: in the Severn generally in May, and it continues there about two months; in the Mediterranean, nearSmyrna and Rosetta; and it ascends the Nile as ligh as Cairo in December and January. The pilchard appears in shoals on the coast of Cornwall, from June to the end of the year; and the tunny comes in-shore on the coasts of the Mediterranean in summer. All these fishes appear to have the same habits of gregariously visiting various coasts and rivers at particular seasons, for a similar purpose; but no one would on this account pronounce them natives or inhabitants of a distant quarter of the globe.

In short, from all the circumstances known of the natural history of the herring, in regard to its visits on 
our own coasts and the coasts of other countries, it is reasonable to conclude that it inhabits the seas in the neighbourhood of the coasts on which it sparwns, and that it arrives at particular scasons near the coasts for the purpose of spawning, the shoals leaving the coasts immediately thereafter; and the early or late, and distant and near, approach to the coasts in different years, perhaps depends, as before remarked, on the clear and warm, and dark and cold, weather of the season, as well as upon the depth of water at the feeding and spawning grounds. 


\section{B O O K II.}

\section{ON FISHING AND CURING.}

\section{CHAPTER I.}

OF THE DIFFERENT MIODES OF FISHING THE HERRING.

\section{THE SCOTCH METHOD.}

Boats.-In fishing herrings on the east coast of Scotland, the fishermen generally use open boats, the largest being about 38 feet in length and 14 feet in breadth, having two masts and four sails; but on the west coast, boats, with half decks, are used, which are superior to those generally in use on the east coast, as far as comfort is concerned.

Nets.-The strongest and most durable nets are made of hempen twine, and were formerly principally made by the family of the fisherman; but of late they have been manufactured by patent machinery. Nets of cotton have been lately used, and although not so durable as those of hemp, they are cheaper, and are found, when not dyed, to take a larger quantity of herrings. Each net has generally from 12 to 15 score of meshes or squares, and is 50 yards in length; and each boat has from 12 to 50 nets on board. The meshes of the net are in some cases 1 inch, and in others, $1 \frac{1}{1}$ inch square; therefore, a. twelve-score net of 1 inch square is 20 fect in depth; 
of $1 \frac{1}{4}$ incli square, 25 feet; and a fifteen-score net, 25 feet, or 31 feet in depth. The law requires that each mesh shall not be under 1 inch square. In preparing the net for the fishing, the upper part is fastened to a rope made of several cords joined in one, frequently as many as twelve; this is called the rope or cork baulk. The ends of each net are strengthened by being attached to a rope (or cords of two or three plies joined together), which ends are termed in certain coasts lugs. The lower part of the net is joined to another rope of two or three plies of cord, which of course, in ordinary cases, must strengthen the whole; but when fishermen fear that the nets may come in contact with foul or rocky ground, the cords or rope of the lower part of the net are left off, which prevents the net being tom so much as it otherwise might be. At the lower part of the net are loops, to which sinkers (of stone or other substances) can be attached when considered necessary.

Buoys. - When about to be used all the nets are united together at the top, and between each net is fastened a buoy to a rope of four to eight fathoms in depth; the buoy attached being in some places an inflated sheep or dog skin; and in other places, four inflated ox-bladdersthe buoys being tarred, and the initials of the owner of the net painted on the outside, this being the only distinctive mark by which fishermen in case of storms, or entanglements of nets (and the latter circumstance, from want of proper management, often occurs), can know their own nets.

Fleets or drifts of nels. - The whole of the nets united are termed a fleet of nets, and in some places (where the nets are not anchored, and the boat attached to one end 
of the whole, when they drive along with the wind or tide) they are termed a drift.

Before proceeding to the fishing ground, the whole of the nets are carefully stowed into the boat in regular order, the oldest being generally piled on the top, and, of course, first thrown out.

Fishing-ground.-On arriving at the fishing ground, and after sunset, while some of the men are rowing, or steering the boat under sail, across the current or stream, the others are carefully "shooting" or shaking out the nets into the sea; the whole fleet of nets, when thus thrown out, is (if not anchored) attached at the stem or bow of the boat to a two-and-a-half inch rope, of about forty fathoms in length; but in cases where the water is not too deep, the fleet of nets is attached at each end to a rope and anchor thrown into the sea, which retain the whole in a proper position, notwithstanding the winds or currents; but in many cases the depth of the fishing ground preveuts anchoring, and there is, besides, another objection to it, namely, the tide or current may be so rapid as to elevate towards the surface the lower part of the net thus opposed to the stream.

Anchor or drift.-In either case, where there are many boats confined to a small extent of fishing ground, it is absolutely necessary that all the fishermen previously agree whether the nets shall be anchored, or whether they shall drift; as otherwise, the boats and nets drifting may come in contact with those anchored. At most of the fishing stations it is therefore previously arranged among the fishermen which of the plans is to be adopted.

Hauling the Nets. - When the fishermen consider that the nets lave remained a sufficient length of time in the water, or when they see the buoys sinking with the weight of 
herrings in the net, or when, by pulling in part of the net, they see that a sufficiency of herrings is caught, or generally (in ordinary occasions) at daybreak, they haul their nets by bringing the end of the fleet of nets to the side of the boat, and spreading them as they take them in, shake the herrings into the boat, at the same time laying the nets regularly above eaeh other.

The herrings are thereafter, sometimes at the fishing ground, and sometimes at the shore, delivered to the purchasers, being in most cases measured by a wooden measure of the size of a herring barrel, called a cran, or into baskets of a regulated size, into which the herrings are lifted by shovels; in some cases, particularly on the west coast when scarce, they are sold by the number.

Seining.-Seining or taking the fish at sea, or on shore in nets, after performing a circle or semicircle, is sometimes practised, particularly in the Clyde, but it is considered objectionable.

Yairs.-There is a very simple and primitive mode of taking herrings without nets, namely, by means of yairs. These are formed by driving stakes into the ground, at the low water of spring-tide; the stakes are crossed with twigs or brush wood, which together form a kind of wickerwork, and sometimes enclose large quantities of herrings. There are also yairs of stone at Lochbroom, Scalpa, Portrec, and other places. Yairs are generally in the form of a semicircle from the land, and are lower than high water, and the herrings which enter them are left by the receding tide. As many as 2000 barrels of herrings have been taken off the glebe of the parish at Lochbroom in a yair (built there by the clergyman of the parish) in a single night; lut these yairs are considered injurious to the fishermen, as their nets are damaged 
when they come in contact with them, and the boats are prevented fishing when the shoal is largest. The fishermen of Lochbroom and adjacent districts were so impressed with the injury done to the fishery, that on one occasion they proceeded in a body, and in two days removed them; but Dr Ross, the clergyman, laid the case before the Lord Advocate, and six of the fishermen were tried and sentenced each to two mouths' imprisonment, for using force in the demolition of the yairs; it may, however, be questioned how far it is right to allow such impediments to the fishermen in their lawful avocation in an arm of the sea.

Cruives.-The cruives or wicker baskets, sunk in the tideway of the arms of the sea and rivers, as may be seen at the present day in the Forth near Kincardine, is another primitive method of fishing; although not exclusively used for fishing herrings, they often take considerable quantities, as well as sprats, young herrings, and other fishes.

\section{YARHOUTH FISHERY.}

Fishing-vcssels. - This fishing is principally carried on in three-masted decked vessels, or luggers, of from 20 to 50 tons, having three lug sails, top-sails, mizen, fore-sail, and jib, and they are so strongly coustructed as to be able to remain out in any kind of weather. The largest vessels have twelve men and a boy. The crew are paid according to the quantity of herrings caught.

Nets.-Every vessel of an ordinary size shoots 100 nets, each 48 feet in length, and 30 feet in depth, and each net is attached by two seizings of one-and-in-halfinch rope, having a deptl of 18 feet, to a four-stranded (gencrally four inch) warp of 3600 feet in length, or, more properly speaking, there are five warps of 120 
fathoms each, joined together, making the length of 600 fathoms, or 3600 feet. This warp, with the nets, is made fast to a rope from the bow of the vessel, which rope, in stormy weather, can be let out, to ease the strain, to the extent of 100 fathoms; but in ordinary weather there is only about 40 fathoms out, that is, the distance from the vessel to the nearest end of the nets is 40 fathoms, or 240 feet.

Spare Nets.-Besides the 100 nets in the water, each boat has generally 100 spare nets on board, to be used in case of injury, or loss of the others.

Buoys.-For each net there are two buoys, being barrels of about the size of a half anker, of about four gallons measure, attached to the warp; and there are, besides, four buoys to mark the distance, one at half the length of the whole of the nets, painted half red and half white, and other two at the quarter distances, quartered red and white; and at the extreme end is a smaller cask painted white. All these buoys have the names of the ship, master, port, and owner, painted on them; each net is, besides, furnished with pieces of cork to give the upper side the necessary buoyancy.

Time of Fishing.-The vessels proceed to sea about the beginning of October, and the fishing lasts two months or more. They fish about half seas-over in about fifteen fathoms water, guided generally by the birds or thickish water. They shoot their nets at sunset; the nets are taken in once or twice in the night, and at daylight. With such a length of nets, a considerable quantity may be caught at one time, and as many as ten lasts (about 100 barrels of herrings) have been fished at one haul. The nets are taken in by means of the capstan; when brought to midships, they are shaken into the main hold, 
where the herrings fall upon a platform, and are immediately roosed (strongly sprinkled with salt), and put into boxed apartments of the hold on a level with the platform, but sufficiently elevated to permit the pickle, or liquid from the herrings, to run off. The vessels return to port as early as possible in the beginning of the season, on account of the value of the first herrings, say with one and a half or two lasts (fifteen to twenty barrels). We may form some idea of the extent of this fishery from the circumstance of there being sometimes 500 decked vessels engaged in it. The utmost precaution is necessary to prevent entanglement of the nets; consequently, no fishing vessel anchors, excepting during the day, when the nets are not out, or unless the weather is so calm at night as to prevent the possibility of shooting the nets; and during night each vessel has a lantern at the bow upon a pole sufficiently elevated to be seen at the distance of five miles. It is evident a unity of purpose and a unanimity in execution are necessary; for if some were to persist in anchoring and others to drive or drift, serious injury would occur. A very good understanding exists among the fishermen as to finding stray or lost nets, namely, that if seen they shall be immediately taken in and delivered to the vessel they belong to, upon payment of one shilling for each net. During the two months the boats are at the fishing, they gradually proceed as far east as Aldbro', a distance of about thirty-five miles from the spot where they commence.

As it is the fishermen's opinion that the herrings are smallest near both coasts, they generally go half-sea over, to get the largest horrings, which are preferred for smoking. The fishermen here have frequently observed that, during a storm or gale of wind the herrings sink and dis- 
appear, but after a storm they generally expect an abundant fishing. This fishery has been long frequented by the Dutch and French. The Dutch generally cure them for immediate use, or for the purpose of being smoked, but the French generally cure them as white herrings. The Dutch have their usual fishing-busses suited for that fishery, being flat-bottomed; and the French have sometimes vessels as large as 70 tons measurement.

\section{HASTINGS FISHERY.}

Hastings Method.-They commence fishing herrings off Hastings in November: each boat has from forty-six to sixty nets, 30 yards in length, and 27 feet in depth; and here the fishermen are careful to shoot their nets north and south, or across the tide, which runs east and west, so that they may drift with the ebbing and flowing of the tide. When there is little or no wind, the nets are allowed to sink within a yard or less of the bottom, but they generally place them near the surface when there is a good breeze. It is observed here by the fishermen, that if the wind prevails for some time from the north-west, this being off the land, and the water of course smooth, the fishing is generally successful; but if a south or south-east wind prevails for some time, the fishermen are often unsuccessful, and they consider that the herrings in that case proceed to the opposite coast.

\section{IRISH COAST FISHING.}

Irish Methods.-The modes of fishing on the coasts of Ireland are various, and some of them remarkable; the 
nets and boats are of various dimensions, and their size and number depend on the means of the fishermen.

Nets.-The nets are generally made of flaxen twine, while they ought to be of hemp, this substance being more durable; and they are most frequently tarred, instead of being barked. The tar must give a disagreeable flavour to the horrings; besides, tarred nets are not so durable. The fishermen in some localities, at Killyluegs for instance, generally anchor their nets, leave them in the water, and proceed on shore, and return to take them in the following morning.

Scine or Haul Nets.-At Valentia they have a mode of fishing with deep-sea "seines" which is generally very productive. These seines or hauling-nets are composed of fifteen nets joined together, five nets in length and three nets in depth, each single net being 20 fathoms in length, and 170 meshes, or 5 fathoms in depth, so that the whole net, when joined, is 100 fathoms in length and 15 fathoms in depth, with a cork-rope at the top, and leaden sinkers at the foot-rope. In attaching them to the rope, seven yards of net are put on to four yards of rope in the centre, and at the breasts and wings onethird is taken in, or six yards of net go to four yards of rope ; the centre part of the net, for about 20 fathoms, is stouter than at the breast and wings, three threads being in all the twine, but that for the centre is spun thicker. There are two warps requisite, each about 60 fathoms in length; and there are small half-inch ropes called braits, fixed to the foot-rope, that are hauled up to purse the net, and bring in the foot-rope quickly, so as to prevent the fish escaping at the bottom, the top-rope always floating on the surface. These nets are gencrally supplied by fifteen men, each bringing a drift-net, or pieco of netting of the 
requisite size. In some cases one individual supplies the whole, who, for the use of his nets and boats, gets $\frac{14}{30}$ ths of the fish-the master seaman getting $\frac{2}{30}$ ths, and the other fourteen men getting $\frac{1}{30}$ th each. They pull their boats so as to surround the shoal of herrings; and when they haul in about 10 fathoms, they pull upon the foot-rope, and tuck the fish into the largest of the two boats which always accompany each seine-net. The size of the mesh is from 1 to $1 \frac{1}{8}$ inch square; from 80,000 to 100,000 herrings are sometimes taken by such a seine in one haul. These nets are in general use on the coast between Dingle Bay and Kenmare. The whole seine may, if necessary, be separated, and converted into drift-nets by addition of ropes, corks, and leads to each.

Curragh Fishing.--The Curragh, or boat made of hoops, and covered with canvas, is much employed in fishing herrings in various parts of the coast, and even this peculiar antique boat is sometimes not to be had where it could be of use.

Fishing with Horses.-Horses are employed instead of boats where the latter cannot be had, but it appears that the fishermen complain of this opposition. In the first Report of the Irish Commissioners, page 11, it is stated that the "fishermen complain a good deal of the practice which the farmers have, of shooting their nets off their horses instead of boats."

Blanket and Sheet Fishing.-An equally striking and unusual mode of fishing is, or has been, practised in Downing Bay. Here it appears that "the poor people, for want of other means, sew their blankets and sheets together, often to the number of sixty, for the purpose of forming an equivalent to a net, each getting a share of herrings in proportion, the people having nothing to 
cover them when their bed-clothes are used in this way." (Commissioners' Report-Lieutenant M'Gladdery, p. 55).

\section{DUTCH FISHERY.}

Dutch "Great Fishery."-The Dutch "great," or "pickled herring-fishery," formerly began on St John's Day, 24th of June, but the fishermen are now allowed to begin earlier. It is that which is carried on in summer and harvest in the latitudes of Shetland and Edinburgh, and on the coast of Britain, with decked vessels, having keels, which can stow twenty lasts of herrings, at the rate of fourteen barrels per last, in the hold, besides the nets; having not less than a full fleet of forty nets on board. The object of this fishery is "to fish herrings of the best quality, and to gut, salt, and barrel them at sea, for foreign sale and home consumption." (Dutch Fishery Laws, Arts. 13 and 14, Art. 3, p. 17.)

Dutch "Small Fishery."-The small or " fresh herringfishery," is that which is carried on between the coast of Holland and Britain, and off Yarmouth, in deep water, with flat-bottomed vessels without keels, which do not usually come into harbour, but upon the beach. It was forbidden to gut such herrings, either at sea or on shore, under pain of imprisonment for one month, and the penalty of five guilders for every hundred herrings, as well as the confiscation of the herrings, unless special permission was olitained (Dutch Fishery Laws, Arts. 15 and 16); but this law is now not insisted on.

"Pan Fishery."-The pan herring-fishery is that which is carried on in the mouths of the rivers and bays, and on the coast of Holland, not farther than three miles from 
the shore. It was also forbidden to gut, or barrel as pickled, such herrings, under the penalty of one month's imprisonment, and of five guilders for each hundred herrings, besides confiscation; but this law is relaxed.

Busses or Fishing Vessels.-Their superior mode of curing long gave the Dutch the command of the various markets where good herrings were preferred, and 600 to 1000 busses used to proceed in former times to this fishery; but for some years back the number of busses has been annually diminishing, and the whole number of herring busses fitted out in Holland did not exceed 90 in 1857. These busses are strongly built vessels, resembling the Dutch galliots or merchant vessels, as sometimes seen in our ports, and are abundantly supplied with every material necessary for prosecuting the herringfishery. They have a sufficient number of oak casks, full hooped at both ends, and a due quantity of St Ubes salt, or of the excellent salt manufactured in Holland; such buss has generally a crew of fourteen or fifteen men. Each buss has generally fifty, and must not have less than forty nets of 32 fathoms each in length, 8 fathoms in depth, and a buoy rope of 8 fathoms; an empty barrel, not quite so large as a herring barrel, is attached to each buoy rope. This fleet of nets is again divided into four parts, for the purpose of noticing the position of the nets, and facilitating the taking them in ; and at the extreme end a white painted buoy is attached, having the name of the vessel and master painted on it. The yarn of the nets must be of good unmixed Dutch or Baltic hemp, which, before being used, must be inspected by sworn surveyors. The yarn must be well spun, and each full net must be 740 meshes in length and 68 in depth, and the nets must be insjected and marked be- 


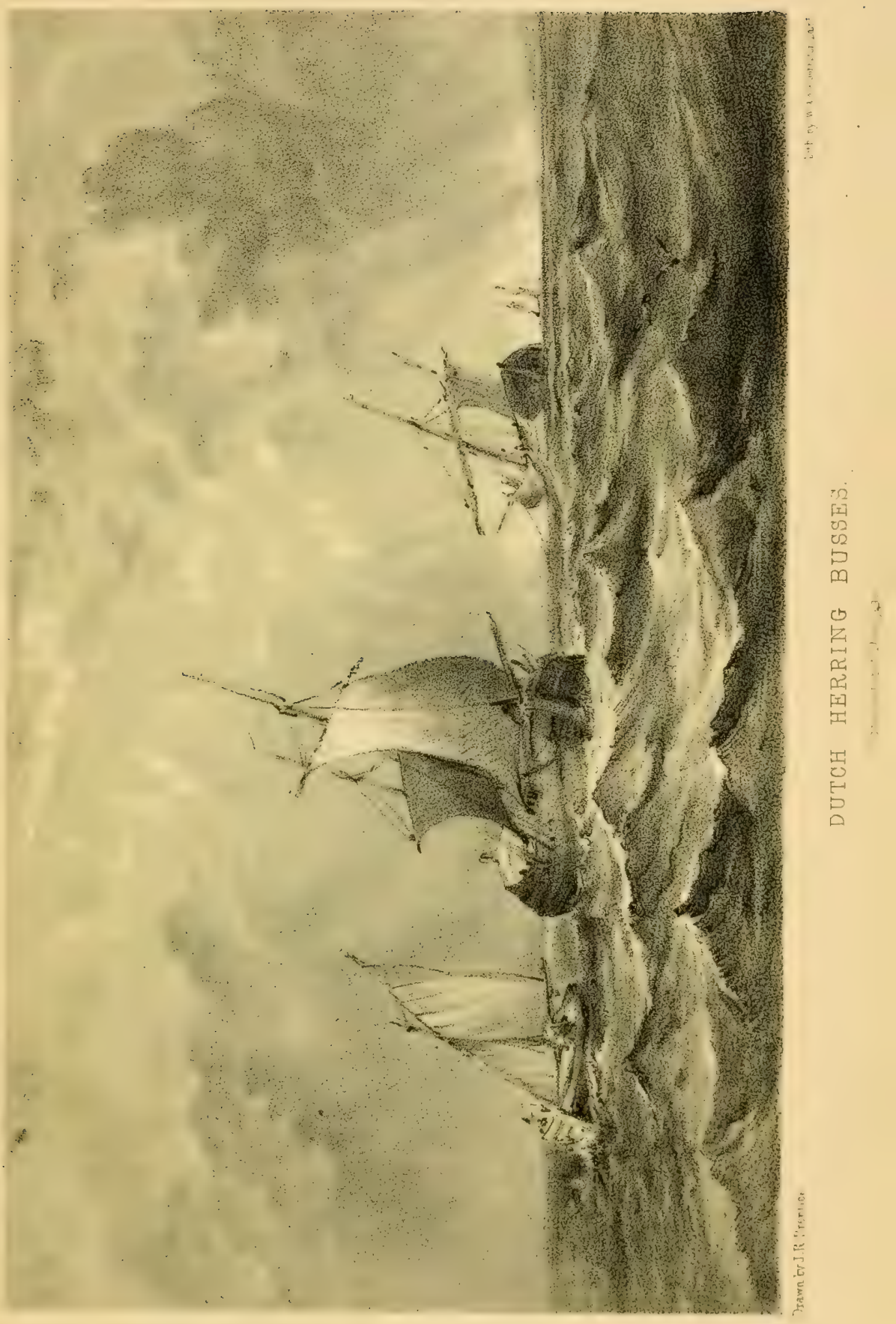



fore they can be used. (Dutch Fishery Laws, Art. 83-98.) The Dutch always shoot their nets at sunset, throwing them to the windward, or in such a way as the wind may prevent the vessel coming upon them. The whole of the nets are attached to four strong ropes joined to each other, and are taken in before sumise by a capstan worked by four or five men, and are shaken out by other four men. The herrings are immediately thereafter gutted and assorted into distinctive qualities,-such as "voll" (full of milt or roe), "matjes" (milt and roe small), "ylen" (shotten or empty), besides other subordinate descriptions connected with the quality, as may be seen where the Dutch mode of curing is described. Eight men are employed in gutting and four in packing. "Jagers" (pronounced yagers), fast-sailing vessels, attend to carry the first herrings to the Dutch and Hamburg markets.

The following are the rules to be observed by the Dutch fishing vessels and jagers during the jager season :-

"(1.) The signals pointing out to what ports the jagers are destined are,- to Vlaardingen and Hamburg, a blue flag; to Maassluys, a Dutch flag; and to Amsterdam, a white flag; - - each having a lierring buss painted on it.

"(2.) When a sufficient quantity of herriugs are caught by the busses, a flag is hoisted at the top-mast, and the jager hoists a flag under the signal to show that the signal has been observed.

"(3.) The busses are to remain as near as convenient to each other and to tho jagers; and the jagers must be in the latitude of Shetland at the time fixerl by law.

"(4.) The busses are not to deliver lierrings to any other than the jagers appointed.

"(5.) The jagers shall sail from the flect in the order 
and with such quantities of herrings as shall be fixed by the Dutch Commissioners.

"(6.) A jager commodore is appointed to regulate the proceedings of the jagers; and he may order them to proceed with such quantities and qualities as he may see fit.

"(7.) No herrings are to be delivered to the jagers without exchanging signed jager-lists, with the date of delivery, stating the quantity and quality, and whether packed or unpacked; and the unpacked can only be given to the two first jagers, and to those going to Hamburg.

"(8.) No herrings to be considered as packed unless the barrels have lain a night in the hold, and the day after (or later) repacked. Besides their wonted mark on the side of the barrel, there must also be the first letters of the master's Christian and surname, and these under a $\mathrm{V}$ for full, and an $\mathrm{M}$ for matjes, before being delivered to the jagers.

"(9.) Those captains of busses who have not delivered herrings to the jagers must, on their return, if required, prove that it was not in their power to do so, or they may be fined.

"(10.) Each master of the busses must deliver the herrings he has on board to the homeward-bound jager if required, which must take the herrings offered by the master of each buss indiscriminately.

"(11.) The masters of the jagers must take note of the busses they meet, and of those that do not deliver herrings, and give or send a list of them to the Commissioners on their return.

"(12.) Any contravention of these rules renders the masters liable to be dismissed without wages, and not to 
be again employed." (Orders voor Jager's en Stuirliecten behoudene tot de Haaring Vischery van Zuid en Noord Holland.)

The Dutch herring-fishery laws have lately been considerably modified; and the advantages of a Fishery Board and inspecting officers having been fully ascertained from the great success of the British system, the Dutch Government has created a Board of Commissioners, with similar powers to those possessed by the Commissioners of the British Herring-Fishery.

\section{NORWEGIAN FISHERY.}

Nomegian Method.-The herring-fishery of Norway is vory considerable, and gives employment to a great number of the inhabitants on the sea coast. The modes of fishing are various, and there is great variety as to the size of boats and number of nets. The general practice is, that when the lerrings are caught near the shore, the boats carry the herrings to the curing stations, or, if at a distance from the shore, there are large vessels lying, with barrels and salt, prepared to buy and cure. The nets and mode of fishing are similar to ours; but there is one mode of fishing which has not yet been practised on our coasts,-namely, with a long range of strong nets, having small meshes to prevent the herrings being fixed in the meshes, which would cause the nets to sink, and defeat the purpose for which they are intended, they often drive into the narrow bays or creeks among the rocks, where the herrings abound, an cnormous body of herrings, where, the nets being made fast, the herrings cannot escape, but are taken out and cured at leisure. A friend lias sent us the following interesting description of 
a scene witnessed in the beginning of the year on the coast of Norway :-

"Being desirous of seeing the bustle and details of the herring-fishery on the coast of Norway, I proceeded in a boat, on Tuesday the 24th January, to the coast near Hitteroe. The morning was beautiful beyond description; there was not a cloud, scarcely one degree of cold, and not a breath of wind, although the sea rose in lofty undulations. The first appearance in proceeding out of the bay was innumerable masses, like floating houses, which turned out to be boats filled with empty barrels piled high on deck. The nearer I came to the Sound, the more numerous were the fishing vessels; and the Sound, or Narrows, which is about two miles in length and some hundred fathoms in breadth, was almost covered with a great variety of vessels,-namely, of that description which were full of empty casks, large pilot boats from the east coast of Norway, and sloops and other decked vessels. On arriving in the Sound, I observerl, along the coast of Hitteroe, a lengthened range of boats and nets projecting from the shore. Having sailed out to the Qualsbjerg or Hualsbierg (the whale's rock), which lies at the outer end of the Sound, I was surprised and delighted at the sublime sight. Boats and nets appeared in hundreds upon the beautifully transparent ocean; the busy voices of the men mingled with the shrill pipe of the sea-gull, countless myriads of which rere waging war against the herrings along with the fisherman and the whale. The birds, in rapid evolutions, were whirling in the air, or dipping in the wave, their snow-white watery plumage sparkling like diamonds in the sunshine; and in the distance, at various intervals, watery columns appeared as if rising from the ocean, caused by the blowing 
of the numerous whales following the herrings. Having proceeded a little farther on, and while looking at the birds, whose eager appetite and rapid motion attracted the eye, suddenly a rushing sound aroused me, and a large wave elevated the boat to an unusual height. Turning my head towards the point from whence the noise came, I cried out, 'Keep back, there is a rock a-head.' The people in the boat turning round, smiled, and said, 'It is a whale.' Part of its body was raised about eight feet above the water, and as it lay near the bows, it seemed at least thirty or forty feet in length; the head and tail were not visible; but it was black, and in some respects like a rock, and on its back the upraised herrings brightly shone and leaped. My boatmen rowed silently backward, and after the lapse of thirty or forty seconds, the monster sunk slowly about two feet, and in a moment sent up a waterspout, of the thickness of about a couple of feet, with great force, to the height of several fathoms, and with a noise that resounded among the neighbouring cliffs. As it did not again appear, we rowed in among the small islands, where the nets were now being taken in, the fishermen having long rollers along the sides of the boat, to facilitate their hauling in the nets, the threads of which were not visible from the quantity of herrings. At a distance the net appeared like a white cascade falling into the boat, and shining brilliantly in the sun. The boats were soon loaded, and they were then rowed either to the shore or to the larger vessels which cure or bring the herrings to remote salting-places. The herrings are all sold by the number, twenty-four score being considered equal to a barrel of fresh herrings of ordinary size. The seller counts them out by fours, calling out the number, while on the deck of the buyer's vessel two 
men stand to see that the counting is correct. At every salting station may be seen piles of thousands of empty barrels, and two persons can prepare twenty-four barrels of herrings per day in gutting, salting, and packing. A barrel will hold about twenty score; but after remaining in salt eight or ten days they subside, and the barrel then requires three or four score more to fill it, after which it is headed up for sale. On the other side of the Sound we saw what is termed a 'lock, - - that is, several nets joined together, forming a bar before a small bay, into which the herrings were crowded. In this place there were several thousand barrels of herrings, so compactly confined together that an oar could stand in the mass. There were in the neighbourhood of Hitterve altogether about 4000 or 5000 nets, and about 2000 boats and vessels; and there were caught, according to the opinion of several intelligent persous, this day not less than 10,000 barrels."

\section{PRUSSIAN METHOD.}

On the Prussian shores there are two modes of fishing, which are as follows: After the ice departs in the spring, and from February until June, they fish herrings principally by means of seine-nets; and the seining is always carried on at night. The shores being generally a fine sandy beach, are well fitted for this operation. There are eight men attached to each net, which is of a very large size, being from 150 to 200 fathoms in length, and from 2 to 4 fathoms in depth, with a deep bay in the centre, the whole buoyed by corks; the sinkers are generally of stone. The men make signals by means of lights, while the boat is pro- 
ceeding round the semicircle shooting the net. When the rope is fully out, or extended from the shore, the man on land shows a light; and when the bag or centre of the net is thrown overboard, a light is shown in the boat. The boat then proceeds round to the shore, when the rope in the boat, on its coming to land, is taken on shore, and the net is drawn to land by four men at each rope; indeed, the operation is similar to the common mode of seining salmon in this country. Upwards of 300 barrels of herrings have been taken in this way by one draught of the net. These spring herrings being always of an inferior quality, are smoked or used fresh. The other method is practised from September till the winter sets in, and is similar to the common mode of fishing herrings in this country in open boats; these herrings being better than the spring-caught herrings, are salted and barrelled.

\section{GULF OF BOTHNIA.}

The inhabitants of Russian Finland fish the small herring called strömling in spring and harvest, generally with seine-nets. In winter, however, one method used by them deserves notice from its novelty and ingenuity. When the guif is frozen over, and no other mode of fishing can be adopted, they break a circle of holes at the distance of eight or ten feet from each other, and by means of a boat-hook, or small spar, they carry round ropes attached to the ends of the net, and thus form a circle with the net in the water under the ice, and drag it out at a large hole at one side. By this mode they frequently take considerable quantities of herrings as well as other fishes. 


\section{Behring's stratts, \&c.}

The natives on both sides of Behring's Straits are accustomed to fish herrings in summer with the seine-net, but a novel method is practised on the River Kovima in winter. The natives place branches or osiers nearly across that river in such a manner as to prevent the herrings passing, but openings are left for weirs and nets to encircle and take the herrings. 
CHAPTER II.

DIFFERENT MODES OF OURING.

1. SCOTTISH MODE.

1. Measuning, \&c.-The herrings being brought in the boats near the quay, or curing-place, as already stated, are lifted with wooden shovels into a wooden measure without a bottom, called a cran (which measure is branded by the fishery officer, and must contain thirty-six gallons). The cran is previously placed on the cart, or place where the herrings are to be delivered, and upon lifting up the measure, the same having no bottom, the herrings are thereby emptied out of it, without the trouble of tumbling them out; or they are measured in wickerbaskets of a legal size. The herrings are then conveyed to the curing-yard or shed, and are placed in square pits or in heaps.

Salted or White Herrings.-They are gutted (generally now in Scotland) with a knife, by taking out the gills and stomach; and those who cure in imitation of the Dutch, leave the appendices cœei, or crown gut, as it is considered to impart a richer flavour to the herring; they are then roosed (sprinkled with salt), and thereafter those employed in packing put a quantity of salt in the bottom of the barrel, and a layer of herrings is then closcly laid together on their sides (if in imitation of the Dutch, nearly on their backs); and alternately a portion of salt and a layer of herrings, until the barrel is properly packed. 
After remaining three or four days, the barrel is again opened, when the herrings are found floating in pickle; the superabundant pickle is taken out or poured off, and an additional quantity of herrings of the same day's fishing, to fill up the cask, is packed in ; a quantity of salt is then laid on the top of all, and the barrel is headed up, and it is then ready for branding. According to the existing British fishery laws, such barrels must be marked in the proper manner, to show the month and day the herrings were taken, cured, and packed, and the mode of gutting, and the year, as well as the name and residence of the curer. The following letters denote the different months:-JN for June, JL for July, AV for August, $\mathrm{S}$ for September, $\mathrm{O}$ for October, $\mathrm{N}$ for November, $\mathrm{D}$ for December, JY for January, $\mathrm{F}$ for February, MR for March, AP for April, MY for May. They must be Roman letters, and scratched on the sides of the barrels with a marking iron, as also the day of the month; all which must be done in a distinct, legible, and permanent manner, and every letter or figure shall not be less than two inches in length; if not scratched, the same may be painted black, but this is never done. The mark to denote that the herrings contained in any barrel were gutted with a knife, and packed within twenty-four hours after being taken, must be three Roman letters, viz., G B K ; if gutted with the finger, G B F; and the mark to denote that the herrings contained in any barrel were gutted and packed, not within twenty-four hours after being taken, shall be G.; and the mark of cured ungutted shall be U.; - which marks shall also be scratched on the sides of the barrels with a marking-iron, or painted black, and not less than two inches in length. The name and residence of the curer, and the year when the herrings were cured, must 
be brancled with a branding-iron in legible and permanent characters on one or more side-staves of each barrel ( 48 Geo. III. cap. 110 ; 55 Geo. IV. cap. 94).

Barrels.-Each herring-barrel must not be smaller than 32 gallons old wine measure, or 27 imperial gallons, and half-barrels may be used, if of legal size. The cask may be of any kind of wood, fir excepted.

Heads.-The heads or ends must be in pieces, not exceeding 8 inches in breadth, and when the herrings are barrelled up, the head must be supplied with a flag or bulrush round the ears or edges; but tow or flax is not objected to as a substitute.

Hoops.-If the herrings are intended for home sonsumption, or exportation to any place in Europe, the casks are full bound at one end, and there are generally three at the bilge and four at the tops. If the herrings are intended for exportation to places out of Europe, the casks must be full bound at both ends, and have, besides, two iron hoops, one at each end.

Dunting. - A dunt or dant is a round solid piece of wood of nearly the size of the head. Dunting is the placing of this on the top of the herrings in the barrel after being repacked, and by jumping, or standing on it the herrings are pressed down.

Blowing.-After the barrel is packed and headed up, there must be a hole bored in the head of sufficient size to enable the cooper to ascertain by blowing into it, whether the cask is air-tight or not; this is ascertainer by observing if any air escapes, and the crevices or openings, if any, must be filled up or tightened.

Branding.-There ought to be $235 \mathrm{lb}$. of herrings washed free of salt and pickle, if intended for home consumption, in each cask ; 224 lb. for the European markets. 
and 212 lb. for places out of Europe. Before any cask of herrings can be branded with the crown brand, they must lie ten free days in the cask; the dlay of their having been packed and barrelled, and the day they are presented for the brand, not being counted. Herrings for places out of Europe, or for the West Indies, must be repacked; they must not be packed with the original pickle and salt, but must be washed and then repacked with fresh pickle and salt. The Appendices caci, or crown-gut, although always recommended by the officers to be allowed to remain for the home and European markets, is taken off if intended for the West Indies or places out of Europe. If the herrings are assorted, namely, the full herrings (herrings full of milt and roe) separated from matjes (herrings with the milt and roe of a small size), and these separated from "ylen," empty or shotten herrings, the fishery officer has authority to apply a brand with the word "FULL" to the first, and the word "Maties" to the second description (the last rord ought to be spelled, being a Dutch word, "matjes") in addition to the crown brand.

Salt.-The fishery officer does not insist upon any particular quantity or quality of salt heing used, but he is entitled to see that there is a sufficient quantity applied for the preservation of the fish.

Brands. - There is a crown-brand of a particular form which must be applied to all crans (the measure for fresh fish) before they can be used. There is the regular crown brand for properly cured herrings; there are two brands, FULL and sraties, as before mentioned. There is a diamond-shaped brand for surplus herrings repacked for the West Indies, or places out of Europe, having the letters $\mathrm{P} P$, and there is a brand in the form of a star, 
which is applied along with the crown brand when the letter has been put on contrary to the opinion of the officer, but allowed because decided in favour of the cures by arbiters mutually chosen.

The officers recommend the curers to lay the herrings, when packed in the barrel, on their backs, when intended for the home or European markets, and those intended for Ireland to be laid upon their sides.

From the judicious regulations of the Fishery Board, and the careful superintendence of the officers, who are practical men, the Scottish herrings furnished with the official brands, which are a guarantee of their quality, have, as already stated, attiined a high cliaracter in the continental markets, and successfully compete with the Dutch; $£ 20$ to $£ 50$ per barrel being sometimes obtained for the first supplies in the continental ports.

2. DUTCH MODE.

Shating out.-The herrings are shaken from the nets immediately when taken out of the sea, and put into tubs or baskets.

Gutting.-The Dutch use a kuife for gutting with a longer handle and sharper pointed blade than ours; they insert the knife into the neck between the gills and bone, and then, by turning the knife, bring away the gills and stomach, leaving the crown-gut or Appendices cceci.

Assorting.-They throw the herrings, when gutted, according to the different descriptions of "full," "matjes," and "ylen," into different tubs or baskets.

Packing. - They are then sprinkled or roosed with salt, and the packers immediately commence packing them into 
barrels, taking care to keep the different descriptions mentioned separate.

Salt.-First, a due proportion of salt is laid in the bottom of the barrel, then a layer of herrings on their backs, the head of the one to the tail of the other; this layer is sprinkled with salt, the subsequent layer is laid across the first, and so on alternately, sprinkling each layer with salt, and a larger proportion of salt on the top; the barrel being thus filled, is then headed up. Due attention is paid as to the quantity of salt necessary, which is regulated by the size and quality of the fish; hut not less than four barrels of salt must be used in pickling "the last" or fourteen barrels of herrings. (Dutch Fishery Lavs, Art. 16.) The herrings cured before St James' or St Jacobi's day, the 25th of July, must only be cured with Spanish or Portuguese salt, and these are named herrings of the large salt; and the full herrings, after that date, must be cured with Dutch-made small salt, and these are named herrings of the fine salt.

Blowing. - Into the ends of the casks holes are bored after they are headed up, the cooper ascertaining by blowing into the hole whether the cask is air-tight, and remedies with rushes or tow any defect in the heads or staves.

Marking. - The master or packer must mark the date when the herrings were taken between the neck and belly hoops, under a penalty; and if unable to pay the penalty, he is liable to imprisonment.

Cured in Time.-Each day's fishing shall be cured and kept separately, and those herrings not gutted and packed. the day they are taken must be thrown overboard, or packed as inferior or wrack herrings, under the penalty of twentyfive guilders for each barrel. In opening the casks and 
filling up, particular care is taken of the surplus li.juid or pickle. It is carefully poured off and barrelled, and the pickle of each day's take is only applied, when necessary, to the herrings originally packed on such day.

Oil.-When the oil appears on the top, on opening the barrels, it is immediately skimmed off, as the herrings would be injured if it were retained in the barrels for any length of time. When exporting, the herrings are examined by the inspectors, who have the power of seizing the barrels and herrings, or fining the owners, masters, or coopers, if not properly assorted.

Inspection.-No barrelled herrings can be offered for sale until examined by the inspector, and branded with the name and arms of the place at which they were imported. The provincial states are authorised to fix the nature of the marks, to distinguish the year and the quality.

The inspector may inspect each barrel twice, and inust take out, and examine to the bottom, at least two barrels in each lot of fourteen barrels.

The penalty on the master of the buss for not properly curing and assorting the herrings is 300 guilders, and his licence to fish may be withheld; and if not properly packed or placed in the barrels, the penalty is six guilders per barrel; and if any inferior herrings are found in the barrels, the purchaser shall not be bound to pay for any other than the inferior quality.

Barrels.-The barrel contains about thirty-six O. W. gallons, or about one-eighth part more than ours. It must be made of new good oak only, and have not less than thirteen staves, and the proper kind and number of hoops; the ends must not have more than three pieces. The cooper is liable to a peualty if he present defective barrels 
to the inspector for branding; and if any herrings are packed in old or insufficient casks, or if the barrels have not been examined and branded by the inspector, the herring's shall be seized, and a penalty exacted for each stave defective. Moreover, the barrel-inspector is liable to punishment if he willingly passes any defective barrels.

Hoops. - The hoops must be whole barel hoops, of the proper quality of red hoops, being of a particular kind of willow grown in Holland, called the Dutch willow, a variety of Salix alba, with a brownish bark. No barrel shall be exported having fower than fourteen hoops, and the herrings caught after St Jacobi's day must have sixteen hoops. Each barrel of herrings, as they are cured, must be marked by the coopers or packers, and on the inside with their private mark, under the inspection of the master.

Marks and Brands. - When the herrings are produced to the inspector (bracker or keurmester), he compares the marks of the quality with the stock, and upon the end of the barrel sees cut with a marking-iron the distinctive marks of the quality.

The fine salt herrings, before they can be repacked or branded, must be two days in pickle after they are taken, under a penalty. The small salt-wrack herrings, being full herrings of inferior quality, must be also branded with distinct marks, indicative of the quality and time of cure, besides the provincial or local brands.

Merchants must not send herrings away, either for home consumption or exportation, without applying their customary mark to the barrels, which mark they must previously communicate to the secretary at the place of their residence, so that the same may be registered.

No herrings can be branded with the large or Rouen 
brand, excepting good cured cross herrings. The her. rings sent to the Elbe and Weser must be well cured, and repacked from fourteen barrels into twelve barrels; provided, that in so repacking them into this quautity, the herrings are not injured; otherwise no such herrings can be sent to the above places. Herrings repacked from fourteen or twelve barrels, shall be branded with the large branding-iron, but those repacked from fourteen to thirteen barrels, with only the date-iron.

IIaving carefully observed the system of curing practised by the Dutch, both on our own coasts and elsewhere, I have here endeavoured, as minutely as possible, to describe their whole process; and it may be stated, that the curing the herrings, as soon as caught, with superior salt, in oal castis, may be the cause of the Dutch herrings having obtained such a high character. 


\section{CHAPTER III.}

CURING OR PREPARING SMOKED OR RED HERRINGS.

Herrings intended to be cured red or smoked, as soon as possible after having been taken out of the nets, and measured, are salted into barrels with a due proportion of Liverpool fishery salt, or Lisbon salt. The latter salt is preferable.

If the herrings are to be made into "keeping reds," they remain in the barrels in the salt and pickle two or three days; then put on the spits, round pieces of wood prepared for the purpose, capable of supporting about twenty herrings on each, the spits being put through the mouth and gills; then, in large square tubs or water-tight boxes, the spitted herrings are washed by being repeatedly plunged in the cold water. These tubs or boxes are of the requisite width to admit of the two ends of the spits to rest on each side. Before being spitted, if the herrings have been a long time in salt, they are laid loose in the cold water, which is repeatedly emptied, and renewed with fresh water. They are then taken out of the steeping tubs, and hung up on the spits to dry in the open air, if the weather is favourable, or in the herring--house, before the fire is applied, for a whole day.

When sufficiently dried, the herrings on the spits are suspended in rows in the smoking-house, which is properly fitted up with beams, so that the whole may receive a due and equal proportion of the smoking process. 
The smoking process is best effected by fires of oak billets placed at intervals on the floor of the herringhouse.

Those herrings which are prepared for home consumption are subjected to the smoking process ten or twelve days.

Those herrings which are intended for exportation undergo slower processes. The extent of the heat is regulated with a view to the colour of the fish most suitable for the different markets, the time occupied in smoking the herrings intended for exportation being from fourteen to twenty-one days. When it is wished to give the herrings a bright yellow colour, the smoke of burning oak sawdust is applied after the first smoking process.

After this the fires are taken off, and the herrings allowed to receive a sufficient time to cool before being: packed into barrels.

Bloaters are those herrings which are cured and smoked for immediate use by a rapid process, which consists of putting the herrings, immediately after being landed, into a very strong pickle of salt six or eight hours. They are then spitted and washed, and put up in the smoking house with slight fires, which haü been previously burning for some time, and consequently yielding only a small portion of smoke. The time they are thus suspended varies from six to ten hours, and they are thereafter cooled, packed, and ready for sale.

Kippered herrings, after undergoing the process of being partially salted in pickle, are also cut open and slightly smoked, and in this way afford a very pleasant change of food. The superior description of leerrings fished at Loch Fyne and other localities on the west coast are much esteerned when prepared in this manner. 
The trade in smoked or red herrings was formerly much more considerable than it now is. At almost all the principal fishing stations large buildings were erected for the purpose; but, excepting at Yarmouth, the trade has diminished considerably. This may be attributed to there being no legislative enactments applied to the curing and preparation of red herrings, in the same manner as applied to the curing of British white herrings. The consequence has been, that the purchaser can have no confidence in the quality of the herrings nor in the size of the barrels, and therefore merchants at home and abroad do not purchase cargoes as merchandise, and the curers, as is the practice at Yarmouth, must send the red herrings not used in this country to foreign countries for sale on their own account.

In explanation of the preceding remarks, we have to quote an extract of a letter from a house which had ventured to purchase a cargo of herrings, to prove that neither respectable names, nor even a judicious selecter can guarantee the merchant who buys that the article intended to be bought has been purchased:-

"We think it fair to admit that we are thoroughly persuaded, although we are strong advocates for free trade when it can be properly carried out, that the curing and preparing of herrings is of such a complicated nature, that, without the superintendence and care of the fishery officer, mercantile transactions could not be carried on safely to any considerable extent, and we shall give you an exact account of our dear-bought experience to prove this.

"We sent one of our fast-sailing coppered schooners to one of the principal places for red herrings, to load a cargo purchased by us. One of ourselves went and examined the different kinds of red herrings for sale in the 
hands of the most respectable curers. He saw several, many casks opened, and thought he had bought the quality necessary; but, 'to make assurance doubly sure,' we engaged two of the leading agents at two neighbouring ports to examine the parcels purchased at shipment, so that error or fraud might be prevented.

"The captain, a most intelligent man, was also acquainted with the qualities of red herrings, and to him we confided the shipment for sale. He went to sell his herrings, and when he began to deliver them to the buyers, it was found that the barrels generally contained a better kind on the top; that refuse qualities were in the middle; and although we bought the whole cargo as well-packed barrels of full herrings, the barrels, when emptied out by the buyers, were found to be very inferior, to our serious loss,-namely, part of the leerrings were not properly cured, and part of them were empty or 'shotten' herrings. From that time we resolved neither to buy red herrings for ourselves, nor to take the responsibility to buy them for our correspondents abroad, and we do not now know any one who would do so who knows the trade. We attribute the inferiority of the quality partly to the reckless conduct of the servants of these curers, who were considered honest men, and partly to the dishonesty of some of the curers, who really sold a fraudulent article; and until the fishery laws are extended to the curing of red herrings, we do not think this trade will flourish."

We think it right to quote this letter, and to remark, that if such difficulties arise as to making red herrings a staple article, which can be, comparatively speaking; easily examined in the casks, how much more difficult it would be, if our British white herring trade (the barrels with the herrings lying in salt and pickle), were left to 
the frauds, blunders, aud ignorance of curers. We admit that the name of the honest curer might go far to secure quality in some cases, but there are so many circumstances connected with curing herrings, that we do not know any security sufficiently strong in the most honest curer that would guarantee to the buyer that perfection of quality that is obtainable by our fishery laws.

\section{MODE OF CURING SARDINES IN FRANCE.}

Although we have proved that the sprat or garvie is a distinct fish from the young herring, still, as some consider it is the young of the herring, and as some young: herrings may be used in making sardines, we do not lesitate to give an account of the mode of curing it on the Frencl coast, under the name of sardine, as it becomes, under the judicious and careful management of the industrious inhabitants of the French sea coasts, one of the most useful and wholesome of the productions of the sea.

Many of the inhabitants of this country are ignorant that at the principal locality where the sprat is fished on the coasts of Brittany, 2500 bcats of 9500 tons, manned by 11,000 mariners, are employed in this fishery; that each boat expends on an average fifteen barrels of the roe of the cod and mackerel, thrown into the sea for the purpose of attracting the fish to the nets, at an expense of about $£ 2$ per barrel of $2 \frac{1}{2}$ ewt.; and that the roes, cured in salt, are principally imported from Norway, at an expense of about $£ 80,000$ annually. This roe is considered indispensable; as various substitutes have been used to attract the fish to the nets, but unsuccessfully.

We could have given many interestiug statistical de- 
tails of this interesting French national fishery, but our object is to point out to the British public an example which might be successfully followed, as to the furnishing an additional supply of wholesome food both for home consumption and exportation. Large quantities are, of course, sold fresh, and transmitted by rail and road to the interior in this country, but the mode of curing has been entirely neglected, excepting small quantities that are smoked, and which are by no means very palatable.

There are two methods of curing the sprat or sardine in France. The first is that of packing them into barrels.

Barrelled loose. - The sprats are first washed and cleaned in the sea, they are then roosed and mixed with a due proportion of salt, and are packed into barrels with a proportion of salt between each layer; in this state they may be sent out for sale.

Pressed barrels. - The system of pressure is by some adopted, in this case, after the sprats have sufficiently imbibed the salt in the barrel, they are taken out and again washed in their pickle, and repacked in a circular manner in the barrel; and, the barrel being filled, on the top is placed strong paper or fig leaves, and above all, a dunt or dant, a piece of round wood nearly the size of the top of the barrel, in which are pieces of wood to secure the beam or bar which is applied for pressing the fish close down into the casks, when the pickle and oil run out into a machine called a tineau; when the pressure has reauced the space occupied by the fish, the barrel is again filled up to the top with more fish, and the cask headed up. Brittany cured in $1853,218,076,400$ sprats, which required 3800 toms of salt, and calculating each barrel as containing 3000 sprats, the number of barrels cured must have been 72,992 , and the fish cured yieliled, from the pressure, 
about six pounds weight of oil per barrel, worth 1 s. $8 \mathrm{~d}$. per $1 b$, or oil to the value of $£ 35,000,3$ s.

FRENCII MODE OF CURING SARDINES (OR SPRATS) IN OIL.

We now come to the second and more delicate mode of preparation, the curing the sprats in tin boxes with oil,a mode which furnishes a delicious and wholesome foud, suitable for transportation to any climate. The sprats are carefully washed in the sea and then carried to the curing place, where they are slightly sprinkled with pure fine white salt; after remaining thus a few hours, women are employed to take off the head, which brings away the gills, \&c., and after again well washing, they are laid out either on willow branches or wire work, and exposed to the sun and wind, or to a current of air, under cover, if the weather is damp or rainy. This drying gives clearness and pureness to the skin. They are then put into boiling oil; after being the requisite time in this oil, they are drained as much as possible, and then put into tin boxes. When the boxes are filled they are carried to tables prepared for the purpose and covered with oil; the tinsmith then takes the boxes and solders on the cover; the boxes are then placed in the boiler, or exposed to hot steam, to undergo the process of ebullition for such time as the curer considers necessary.

After being taken out, the boxes are examined, and those rejected which have leaked, or not resisted the pressure of boiling.

Generally speaking, all the boxes that are not convex on the two sides, when taken out of the heating process, are bad, but the reverse is the case if the swelling in convexity continues after the boxes have become cold. 
The heads and debris are much valued, and sold for agricultural purposes.

There are about forty establishments which prepare the sardines with oil in tin boxes, and the quantity prepared is about ten million boxes anmually. We have been thus particular as to the mode of preparation, because the advantage of preparing the boxes for home consumption and exportation must be obvious. Large quantities are prepared for Australia and California, and in 1853 the quantity exported from France amounted to about $4,000,000$ pounds weight.

In Nomvay as Anchovies.-In Norway considerable quantities of the sprat (brisling) and young herrings are salted and preserved with spices in little kegs. They are first steeped in a strong pickle of Spanish or Lisbon salt, and thereafter packed into the kegs, which are carefully made tight, and thus prepared form a very agreeable food, and are generally eaten in this state raw without any other preparation.

Smoked Sprats.-Considerable quantities of the sprats or garvies are sometimes smoked in this country, but as the labour is considerable in smoking such a small fish, it is only when they are very cheap that the using this process can be made to be profitable. The mode of curing or preparing the sprats is by steeping them in strong salt pickle for ten or twelve hours, and thereafter spitting them and smoking them with fires of oak for eight or ten days, and when cool they are packed into small kits or barrels.

Of course, there are various other modes of curing herrings which may occur to the reader-such as preserving them in tin boxes for exportation, either with or without oil ; and there are other methods of smoking, which have not been entered into; but it is hoped that sufficient has 
been stated to exluibit to the non-practical reader some of the various preparations employed.

One mode of curing has not been referred to-namely, that of curing herrings without the application of either salt or smoke. It may be difficult to do this in hot weather, unless, perhaps, by repeatedly dipping the fish in sea water; but in winter we have tried the experiment, and find that fresh herrings cut open and exposed to the air acquire a firmness which renders them fit for keeping for a considerable length of time, a practice which was probably in use among our ancestors before the process of manufacturing salt was discovered. 


\section{B OOK III.}

\section{CHRONOLOGICAL HISTORY OF THE HERRING FISHERY.}

\section{CHAPTER 1.}

Among the savage nations of the present time we find that fish generally forms part of their ordinary food, and this even where the fruits of the earth are abundant; we may therefore conclude that, in the northern countries, the natives on the sea-shores, in ancient times, must have lived, to a great extent, on fish. Solinus, who wrote about the year 240, says of the inhabitants of the Hebrides, "They do not know the cultivating of grain, and live much on fish and milk."*

The deep bays surrounded by lofty rocks, the numerous arms of the sea, and the rivers sheltered from the storms, must have afforded our savage ancestors their natural food, and enabled them to supply themselves in comparative safety. That, in the most ancient times, our forefathers were accustomed to navigate at least their own rivers, is proved from the circumstance of many boats or canoes having been dug up in various parts of this island, and some such have been dug up on the banks of the Clyde. Pinkerton tells us of a boat, 36 feet in length and $4 \frac{1}{2}$ feet in breadth, having been found near the Carron in

* "Hebrides quinque numero, quarum incolø nesciunt fruges, piscibus tantum et lacte vivunt."-Solin. Polyb., c. 25. Paris, 1503. 
1726, "under several strata of earth and fossils, made up of one entire piece of oak, and well polished."* But, had the ancient inhabitants even been without boats, we have at the present day two curious proofs that they might have supplied themselves without their aid with fishes from the sea,-namely, in the cruives, $\dagger$ or osicr baskets, sunk in the rivers or arms of the sea, as at present practised near Culross, in the Forth, and at Menai Bridge, and the twisted branches or osiers and stone yairs as used at Lochbroom, and other localities to secure the herrings.

How long herrings were used merely by the inhabitants adjoining the lochs and scas where they were caught, and when they became an article of commerce, it is difficult to determine, although it is quite possible that, in ancient times, herrings may have been exported in a dried or smoked state without being salted, yet it is most probable that, until salt was used, the commerce in herrings was inconsiderable; it is worthy of remark, lowever, that herrings are easily preserved without salt by exposure to the air after being opened, and that the practice is still prevalent in some parts of the North Highlands. Anderson, in his "History of Commerce," says that the Netherlanders came to Scotland to buy fish in the ninth century; his words are- "Some writers speak of the Netherlanders resorting to Scotland as early as about the year $\$ 36$, for the buying of salted fish, of the Scottish fishermen, which they then carried home merely for the sustenance of their people, whereby the Scotch were greatly enriched." \$ It is to be regretted that this author does not give his authorities for this statement; and although he does not even mention herrings, yet several

\footnotetext{
* Pinkerton's History of Scotland.

† German Korb, basket.
}

$\ddagger$ Anderson's History of Commerce, p. 41. 
writers on the herring-fishery assume this statement as proving the early period of the herring-fishery.

In the absence of any immediate authority of so early a date as to Scotland, we have analogous data as to the herring-fishery in England,-namely, at Great Yarmouth. Swinden, in his "History and Antiquities of Great Yarmouth,"* supposes that the herring-fishery commenced there soon after the landing of Cedric the Saxon, in 495; and states that the Church of St Bennet was built upon the Greenhill, "and a godly man placed in it, to pray for the health and success of the fishermen that came to fish at Yarmouth in the herring scason," and that it was supposed to lave been built by Felix I., Bishop of the East Angles, in 647, and that afterwards a church, dedicated to St Nicholas, the patron of fishermen, was built upon the Greenhill; and that valuable antiquarian work "Doomsday Book " (a survey of England made in the twentieth year of the reign of William the Conqueror, in 10S6) mentious Yarmouth as containing seventy burgesses, and notices Garteston, an adjacent place, as having "three salt pans," and twenty-four fishermen in Yarmouth belonging to this village.

And Laing, in his valuable book on Norway, quoting: from the "Saga of St Olav," written about the tenth century, says that Sigurd Sir enabler his "trolle" (slaves, thralls, or bondsmen) to purchase their freedom by lending them what was necessary for the fishing of herrings. $\dagger$

The following extract from Olaf Trygrgvesön's "Saga" also proves that, previous to his time, the Norwegians were engaged in the herring fishery,-namely, near the end of Hakon Adelsteensfostre's reign, about the year 952 :- 
"When they came to the coast they gave themselves out to be poor children, and as they went forward they came to a herring-boat, which had come up from Vaagar, and was going to the south, they engaged themselves with it, and by that means had an opportunity of getting southward. When they came to Sogusa they said that they were going into the Frith, as they had friends there," \&c.

In the reign of Harold Graveld (960 to 975) the Norwegians fisherl herrings with large nets from Bohusland, a district near Christiania, to Finmark; and in the reign of Hacon Jarl (988 to 993) there was such an abuudance that all the maritime districts of Norway "were filler with them."*

If we thus find the English and Norsemen so early engaged in the herring-fishery, the date mentioned by Anderson is perhaps near the time when the herringfishery began to be an object of importance to the natives of Scotland.

But that herrings were an article of commerce and of food very early in Scotland is proved by King David the

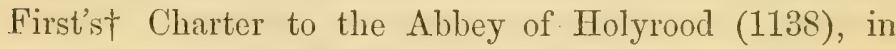
which there is, among the other endowments grauted, the right to fish herrings at Renfrew, the rords being, "Et ibi Renfry (or Renfrew), piscari ad allechtia libere"

The earliest mention made of herrings by the Parliamentary Records of Scotland is in 1240, the following being the words: "Burghe tallys of a last of Herring" IIIID, dry herring at ye further passing 1D, of a thousande herring an thai be lade on a hors. 1D, for ilk birding for ye stalling of the marcat. $1 \mathrm{D} \frac{1}{2} \mathrm{D}$ : Item for a last of fresche lering IIIID, and gif thai be lade throu ye byar yat byis

* Heims Kringla, $186 . \quad †$ Maitland's History of Edinburgh, p. 145. 
thame, bot gif yai be lede to ye havyne with ye fischar, he sall gif naithing for ye hering bot for his set."*

The word "dry" almost implies that the herrings were dried for sale, and not smoked; if the herrings had been salted, the packages or barrels would likely have been mentioned, or subjected to a toll or tax.

We have sufficient evidence to show that herrings were early an article of commerce in various other parts of Europe, some of which we shall now specify.

In Lümfiord (or Limphjor, in ancient acts) in Denmark, a constant fishing of herrings existed twice a year for many centuries; $\uparrow$ and mention is made of the inhabitants carrying on commerce with Bremen for salt in 1054.

A glowing description is given of the prosperity of Denmark, in consequence of the herring-fishery, by an ancient writer. He says: "The Danes, formerly clad like simple seamen, are now clad in scarlet and purple, and every nation carries them abundance of gold and silver in exchange for their herrings." $\$$

The Danish Sound, and upwards as far as Falsterbo, seems to have been long, in ancient times, a place greatly resorted to by fishermen of various mations. $\S$ The earliest notice known of the fishery at the Sound appears in the "Knytlinga Saga;" $\mid$ by it we are told that great quantities were caught there in the fall of the year 1080 . We have also an account of the fishery in that quarter, from a work in 1382, by a French traveller, who addressed his book to Charles VI., and who states that, on the sea "between the kingdoms of Denmark and Norway,

* Parliamentary Records of Scotland, Burghe Tallys, 1240.

† Gheymser Comp. Hist, Dan, apud Langebeck, ii. 288.

† Arnoldus de Lubeck, Chron. Slav, i. cap. iii. v. 121.

? Dan. Rig. Chron., 165.

|| Page 57. 
during two months of the year,-namely, September aud October,-there are 40,000 vessels, each having at least six persons to fish, besides 500 vessels for gutting and packing, and that there are more than 300,000 men who do nothing but fish herrings."*

In 1124 we read that herrings were so abundant on the coasts of Pomerania that a horse load was given for one ore, a coin of about the value of three farthings. $\dagger$

In the years 1242 and 1348 the herring-fishery on the coast of Denmark occasioned two long and bloody wars between Denmark and the Hanse towns, - the latter, with Lubeck at their head, generally obtaining the superiority.

The Hollanders commenced fishing herrings in the Meuse in the year 1163.

Some writers $\$$ state that William Beukelz or Beukelsen, born at Biervliet, in Brabant, was the first person who invented the art of salting or picliling herrings. The historians differ as to the time and place of his birth; some say that he was born at Biervliet, others at Enchuysen; some that he was born in 1347, others in 1397.

It is not difficult to prove, however, that herrings were salted long before that period; for besides the instances already given, we find that a law was made at NiewPort exempting salt herrings from paying duty on account of the salt and barrels used in pickling, long previous to Beukelsen's pretended invention. \|

Professor Valenciennes, in his edition of Cuvier's "Hist. Nat. du Poissous," vol. xx. p. 112, says, "that the earliest notice discovered in France regarding the her-

* Philip de Mazieres, Vecil Pelerin. † †ita Sancta Ottonis, p. 73.

‡ Kronik. van Holland, i. 184.

$\S$ Schoockins, Belg. fad. lib. viii. chap. ii. 221, and Pontanus Discuss. Hist., 74.

|| Placaat ron Flaud, vi. 429. 
ring is in 1030, in the Charter of the Abbey of St Catherine, situated near Rouen, where it is stated that certain saltworks near Dieppe were to pay to that abbey five milliers of herrings; and in 10s8, Robert, Duke of Normandy, by charter to the Abbey of La Sante Trinite at Fecamp, gave permission to hold a fair one day during the continuation of the herring-fishery; and Louis VII. of France, in 1155, prolibited his subjects from buying any. thing in the town of Estampes but mackarel and salted herrings."*

Philip II., King of the Romans, expressly mentions, in a charter granted to the town of Liege, dated 1187, the privilege of buying and selling fresh and salted herrings. $\dagger$

It is clear, therefore, that if Beukelsen had any merit as an inventor, it must have been in the introduction of the practice of gutting them; in corroboration of this supposition, the "Kronikel van Holland" says, "This year (1163) they commenced fishing herring in the Meuse, and the first fishery was established at the Brielle. The fishermen of Zurick Zee were the first to fish them and pack them in barrels; and those of Biervliet were the first who invented the better method of preserving them salted, by gutting and taking out those parts of the herring which before caused them to spoil much sooner.末

On the coasts of Lower Germany, in the Baltic, it is stated, that in the year 1236, the people caught such great quantities that they theu extracted oil from herrings by boiling them.

* Ord. des liois de France.

† Louvrex Recueil des edits et privileges du pays de Liege, ii. 234.

† Kronik, van. Holland, i. 184. §Peringskiold Monum. Uller, 89. 
By information obtaiued from different authorities we learn that the Prussians had commenced fishing herrings on their coast in 1259.*

In 1108 Henry I. erected Yarmouth into a burgh, the annual payment for this privilege being "ten milliers of herrings ; $†$ and in 1199, King John erected Dunwick in Norfolk into a free burgh on payment of L.120, one mark of silver, and 2400 herrings annually.

The Book of Meaux states, that in the year 1240, William de Fortibus, Earl of Albemarle, granted to the monks of Meaux lialf-an-acre of land in the borough of Odd (in burgode Odde juxta Bavenser) for the erection of storehouses for their herrings and other fish.§

So early as the time of Edward the First, 1270 (Longshanks), the herring fair at Yarmouth was held forty days, at which the Barons of the Cinque Ports had deputies for the purpose of keeping the peace.

The following is an extract of the dite or edict by Edward I. for the government of the fair in 1277: "Et aussi voillouns que ceux de la vile de Gernemue voydent den et stronde, des voilles nyefs et de meryne, la ou ils deynont ariver et leur reitz seecher, ce ces n'est desnyefs que sonnt en fesaunt et mastes sur que on les peut secher,"-namely, "And also we will, that they of the city of Yarmouth void den and strand of old ships and timber, where they should arrive and dry their nets, so that it be not of ships which are in building, and masts for drying."

We learn from Blowit's "Fragmenta Antiquitatis," that herrings were early a royal dish in England, for in 1286

* Noel, de la Moriniere. † Thorkelin, Diplom. Adv. Magn. ii. 155.

‡ Anderson's Hist. of Commerce, vol. i. 98. § Lib. Melse, fol. 135.

II Swinden's History and Antiquities of Great Yarmouth, 184, 194. 
Edward I. granted a charter for land at Carleton, in Norfolk, by the service of twenty-four pasties of fresh herrings at their first coming in."*

In the inquest of $18 \mathrm{Ed}$. I. (Longshanks) (1291) the people of Grimsby complained to the king that the trade at Grimsby had fallen into decay in consequence of the inhabitants of Odde forestalling them in their supply of herrings, by representing to the fishermen that the herrings which were actually selling at Grimsby for forty shillings per last, were not selling for more than twenty shillings per last. $\dagger$

We are also informed that the foreigners who came to Yarmouth only came to buy herrings. In regard to fishing, special permission had to be obtained; and, accordingly, it is recorded that King Edward, on 28th September 1295, gave permission to the Dutch to come to Yarmouth to fish herrings; $\ddagger$ and we find that in the year 1294, only after special application, Eric, King of Norway, admitted the English to the same privileges in going to Norway for lierrings as were enjoyed by the natives of the Hanse towns; but this favour having been abused, was subsequently recalled, as we shall find stated.§

In the year 1302, by royal edict, the town of Yarmouth was ordered to furnish ten lasts of herrings for the use of the king, or "in usum principis." $\|$.

At a very early period the town of Yarmouth supplied many of the religious houses in England with herrings. The following are extracts of one of the charters,-viz. In the roll of $34 \mathrm{Ed}$. I. of "Essendi quietum de Tolonia,"

* Blowit's Fragmenta Antiquitatis.

† Frost's Notices of the Early Hist. of Hull ; Note, p. 55.

$\ddagger$ Yair's Account of the Scotch Trade in the Netherlands, p. 13.

3 Thorklin, Diplom. Adr. Magn. ii. 155.

औ $81 \mathrm{Ed}$. i. 1302 . Swinden, i. 84. 


\section{to the bailiffs of. Yarmouth in the year 1305, concerning the charters of Croyland.}

In the time of Yarmouth Fair, in the 34th year of the reign of King Edward, son of King Henry, William de Ketene, monk of Saint Faith, and Reginald de Burgh of St Peter, brought to the bailiffs of Yarmouth a writ of the lord the king in these words :-

Edward, by the grace of God, King of England, Lord of Ireland, to his bailiffs of Great Yarmouth, greeting, \&c.

Witness myself at Newburgh in Tyndale the 30th August in the 34 th year of our reign.

By authority of which writ, the aforesaid Reginald had eight lasts and one thousand herrings delivered free of customs,--viz, five lasts, ${ }^{*}$ and 1000 herrings for the year 34 , and three lasts for the year 33 ;which said eight lasts and 1000 herrings, the aforesaid Reginald swore upon the Holy Bible were the property of the Abbot and convent of Croyland, and for them were bought and provided, besides 12 pence half-penny, which the said Reginald pledged for the aforesaid three lasts of herrings for the custom of the year 33 , are delivered to the aforesaid Reginald at the request and in reverence of the said William de Ketene, monk. $†$
Tempore mundinarum Jern, anno regis, E. fil Regius Henri, xxxiiii., Will'us de Ketene monach 'de sc'a fide et Reginaldus de Burg sc'i Petretulerunt ball'is mag Jernsba'e d'ni regis in hæc verba :-

Edwardus dei gr'a rex Angl', d'nus Hibern' ball'is suis de Mag' Jeru' salutem, etc.

Tme ipso apud Newburgh in Tindal xxx die' Aug' anno re'm xxxiiii.

Anctoritate cujus brevis predict' Reginaldus viii last allic 'et 1 milliar' allic' quietas habuit de costuma deliberatus, videl' $\mathrm{v}$ l'et 1 milliar' de anno 34 et iii last' allec anno xxxiii. que quidem viii last' et 1 milliar allec' predict' Regin' cartis sacrae s'tis juravit esse proprias ablatis et convent' de Croy. land, et ad opus suorum eruptas et provisas; preterea xii denarii 1 obolus quos dictus Regin' posuit in vad'on pro produits iii last' allec pro costuma de anno xxxiii. deliverantur prefato Regin' ad instanciam et reverenciam dicti Will'i de Ketene monachi.

The port of Yarmouth scems to have had a very important and exclusive commerce in herrings, not only in

*A last, 10,000 herrings. † Swindon, pp. 33, 34. 
Englaud, but with foreigu states, for it appears by the Yarmouth murrage rolls, that sixty foreign vessels, ten of which were from Lombardy, entered that harbour for the purpose of procuring herrings, within the five days from the 28th September to 30th October 1344.*

In 1338 Edward III. demanded forty (leths) lasts of herrings from his subjects for the use of his army going to France.t This herring-fishery was about this time, 1357 , beginning to be of importance, for we find that in the 31 of Edward III. (1357) the ancient statute of herrings was made, which is worth recording as extremely interesting for its autiquity, and as describing to a certain extent the peculiar manner of selling and buying, and the privileges enjoyed by the resident merchants (hos" tellers), and the restrictions on the native boats' crews (" pykar"), who were not permitted to buy fresh herrings in the haven of Yarmouth between the feasts of St Michael and St Martin,-namely, the 29th September and 11th November.

The statute of herrings, made anno 31, of Edward III., stat. 2, A.D. 1357 :-

"Cap. 1. No herrings to be bought or sold at sea, nor until the cable of the ship be fixed on shore.

"Cap. 2. The fishers to sell to whom they please at the fair, and the sale to be from sum rise to setting, and no hosteler to pay more than 40 s. per last, and no fresh herrings to be bought by pykars, between the feasts of $\mathrm{St}$ Michael and St Martin, in the haven of Yarmouth.

"Two lasts of fresh shotted herring shall be of the value of one last fresh full herring, and two lasts shotted red shall be one mark dearer than one last full red." 
Large shoals are mentioned as having appeared off Whitby in 1394.

The Scotch seem at an early period to have asserted their claim to the exclusive right of fishing on their own coasts; for on the 14th June 1410, on the petition of the inhabitants of Brauershavn in Zealand, William, Earl of Holland, granted power of reprisals against the Scotch, for their having taken several Dutch vessels employed at the herring-fishery, and after a long continuation of hostilities at sea, a treaty of peace was entered into on 1st August 1416, in which no mention is made of the fishery, and consequently of no compromise having been made.*

In the ancient history of Norwich, there is an amusing account of the celebration of the Christmas festival held there on Fastings Tuesday, wherein part of the herring is made to aid in the decoration of one of the performers on that occasion in 1444. John Gladman was tricked out with tinsel and ribbons, and was crowned king of Christmas, and before him went a personification of the month of December, dressed as the season required, with an effigy of Lent, "clad in red and white herring skins," following him on horseback, the horses' harness at same time having been ornamented with shells, the symbol of those holy men called palmers. ${ }^{\dagger}$

In 1415, Henry V., on complaint of Eric, King of Norway, addressed a proclamation to the towns of "Yernemouth, Limu, Kingston-upon-Hull, Gippewick, Scardebourg, D’Orwel, Newcastle, Grimsby, Berwick, Cranmer, and Dersingham," prohibiting the inhabitants of those towns from fishing on the coasts of Norway, so

* Groot Charter Bock, van Holland, vol. 4, pp. 146, 378.

† Hogg's Instructor, 9th February 1850. 
that the permission given to the English in 1294 seems to have been abused.

We are told that the French caught herrings so early as 1030 ; and in the "Annals of Dieppe," mention is made of their fishing herrings on the coast between the Seine and the Somme about Christmas, in the year 1383.*

By the treaty of peace entered into between touis XI. and Charles Duke of Burgundy, dated 14th October 1468, we find that it was necessary to prevent the molestation of the fishermen, for a clause of this treaty runs thus: "It is agreed that the Fronch shall not molest the herring-fishery of Holland, Zealand, Brabant, Flanders, and Boulogne."†

About the year 1202 is the probable time when the Irish began fishing, as that year John Lackland confirms by charter a donation of herrings to the Abbey of Connal.

It is evident, from the facts we have stated, that the herring-fishery had already, in the twelfth and thirteenth centuries, become among foreign nations an important means of employment, food, and wealth ; that vast numbers of vessels and people were employed; that its importance occasioned bloody wars; and that it afforded food for invading armies. We therefore may expect it had become equally important in Scotland, and, accordingly, we find that in the year 1424 herrings were regularly salted and barrelled as well as smoked.

The Act of the 1st Parliament James I., 26th May 1424,§ says: "Alsua for thay that mony thinges passes out

* Pommerage, Hist. de l'Abbaye de St Catherine, 73. Noel, de la Moriniere Annales de la ville de Dieppe.

$\dagger$ Memoirs of Philip de Comines.

$\ddagger$ Bodl. MS., de Rehas Hib. Fgg. iv. 43.

\& Part of this read at a meeting of the "Society of Antiquaries of Scotland." 
of the realme withoutten custome, it is ordained and decreeted, \&c., that there be paid to the king for custome of ilke thousand of fresche herringe sauld, of the sellar, one penny, and of ilke last of herringe barrelled foure shillings; and of ilke thousand red herringe made in the realme, foure pennies."*

In 1429 the fishing was carried on to a large extent, and the Scottish fishermen caught great quantities at the mouths of the Dee, Tay, Forth, Tweed, \&c., which they principally sold to the Dutch and other forcigners." $\dagger$

The following quaint remarks occur in an ancient liistorian: Speaking of Scotland, "France, Flanders, Zealand, Holland, and mekill of Almany comis with sundry flotis, passand in the time of Lentrown throu the seis Mediterrane aye selland thair fische to thair grit proffit and winning." $\$$

And the same authority tells us that Lochfine had been anciently known as a fishing station: "In Lochfine is mair plenti of hering than is in ony seis of Albion."

The herrings had been equally changeable as they are now, for this author says as to Inverness: "Inverness where sumtym was grit plenti of tak of herring, howbeit, they be now evanist for offens that is maid against sum sanct." $\|$

In the reign of King James III. a law was made regarding the fitting out of "ships, busses, great pink boats, and nets and other abuilzements:" viz., "THAT Lordes, Barrones, and Burrowes, Gar matie sChippis, Busches, and Great pink Bonts with nettes. Item, The Lordis thinkis expidient for the common gude of

* Scots Acts, 1st Parliament James I., 26th May 1424.

† Noel, de la Moriniere, p. 319.

$\ddagger$ Bellenden'sBoece's Cosmographie of Albion, xxiii.

§ Ibid. xxxi.

|| Ibid. xxxiii. 
the Realme, and the great encris of Riches to be brocht within the Realme of other countries, that certain Lordes, spiritual and temporal, and Burrowes gar make greate schippes, Busches, and other great pinck boats with nettes, and all abuilzements ganand therefore for fischinge, and the execution of this matter, and the form and number of the seamen, to be had at the continuation of the Parliament."*

In the reign of King James IV. the Scottish nation saw the propriety of maintaining their own rights as to the fishery; for in 14SS the following Act was passed: "That the strangers buy na fish but salted and baralled, nor buy nane other merchandice, but at free burrowes, and there pay their deuties and customes, and take their cocquet as effeires, and that they make na merchandice at the Leuvis, nor other places, but at free burrowes." $\dagger$

The Act of 1471 was in 1491 extended and confirmed by James IV., Parl. 4, cap. 49 ; but at same time it was improperly enacted, that no ships should go to the herring-fishery under twenty tons, a restriction which must have done much injury, viz.:-

"ANENT THE MAKING OF SCHIPPES AND BUSCHES ON THE QUHILK ALL IDLE MEN SULD LABOUR.

"Item, anent the greate imnumerable riches that is tinte in fault of Schippes and Busches to be disponed for fishing sic like as etheris Realmes his, that are merchand with the sea, and for the Police and conquest, that may be had here intil, and to cause ille men and avengeours to labour for their living, for the escherving

* 6th Parl. King James III., 6th March 1471, sect. 48.

† 1st Parl. James IV., 6th October 1488, sect. 3. 
of vices and idleness, and for the commoun profite and universal weill of the Realme. It is thocht expedient be the Lordes of the articles, and als statute and ordained in this present Parliament, that there be Schippes and Busches maid in all Burrowes and Townes within the Realme, and that the leaste of the said Schippes and Busches be of twentie tun. And that the Twwnes and Burrowes have the Schippes and Busches according to the substance of ilk towne, and to the number as after followis, well abulzied with ilk necessarie graith for the said Schippes and Busches, and with mariners, nettes, and other graith convenient for their taking of great fish and small. And all the said Schippes and Busches to be reddie maid and furnished to pas to fishing be Fastrens even next to cum. And in ilk Burgh of the Royaltie, that the officiaris of the Burgh make all the starke idle men within their boundes to pass with the said Schippes for their wages, and gif the said idle men refusis to passe that they banish them the Burgh. And into Burghs of the schires quhilk ar neare upon the sea, that the Schireffe of the shire compell the idle men within his boundes to passe to the said Schippes for their wages. And gif they refuse in likewise to banish them his schires, and gif the officiaris of the Burrowes or Schireffes of the schires beis found in negligent on this, in putting forth of the said Schippes and Busches, or compelling the said idle men to passe in them for their wages, or banishing them of their burrowes or schires:-Gif they refuse as said is, they sall pay to the king an unlaw of twentie pound ilk ane of them, that is to say, officiaris of the Burgh for the time, and the schireffe of the shires. For the quhilk they sall be cliarged in the checker, and give compt thereupon."*

* 4th Parl. James IV., 26th June 1491, sect. 49. 
In 1532, a disagreement having taken place between Scotland and the Netherlands, the Scotch proceeded to interrupt the Dutch in their herring-fishery, and Robert Fogo, of Leith, with several ships of war under his command, cruised on the coasts of Holland, and took many of their herring busses, upon which all the property of the Scotch merchants in the Netherlands was seized, and Mary Queen Dowager of Hungary, then Governess of the Netherlands, wrote to James V. proposing a peace ; but King James insisted on excluding the Dutch entirely from fishing off the Scottish coasts, and after much depredation was committed on both sides, a treaty was ultimately concluded between Charles V. and King James, in 1541.*

Notwithstanding the protection and encouragement given by the Scottish sovereigns, it does not appear that herrings were as yet caught in superabundance, because the quantity exported prevented, or lessened, the supply required by the inlabitants, to such an extent, that an Act was passed in 1540, limiting the manner of sale so as the inhabitants might first be supplied. This Act is as follows :-

THE TIME OF SELLING OF FISH IN THE MERCAT; ANENT THE WAY CARRYING OF FISH ; OF THE PRICE OF FISH.

"Alsua it is statute and ordained that na maner of person to burgh nor to lande, bye ony maner of fische in mercat nor other places, to packe or peile, quhil elleven houres of the day, and fra elleven houres to twa houres afternoon, it sall be leasum to bye fish, and pack or peile the samin, as they think maist expedient. And not the lesse that all our Soveraine Lordis lieges, cargers, and others within that time of the day be served for their

* Yair's "Hist. of Scottish Trade in the Netherlands," p. 103. 
money, of fish to the furnishing of the cuntrie: And sic like fra twa houres after noone to sex houres at even, it sall not be leasum to bye, pack, or peile, the saidis fish, bot that all our Soveraine Lordis lieges at the saidis times of day may be served of all maner of fish, and bye the samin for their silver, for sustentation of their house, and serving of the cuntrie about: And that na maner of person in this realme, merchand, or uthers, send, or have ony maner of quhite fishe foorth of the samin, bot it sall be leasum to strangers to cum within the realme to bye the samin fra merchands and free men of burrowes with reddie gold or silver, or be bartouring of sufficient merchandice with the saidis merchandes, or with the owners thereof, for their sustentation, necessares of their houses allanerly: And quhair ony persones hes ony fishe packed or peiled, that they be rearly at all times to sell the samin to all our Soveraine Lordis lieges for furnishing and sustentation of their houses, and the countrie, under the paine of confiscation of the samin. It is statute and ordained that the provests, aldermen, and baillies of burrowes in everie mercat day passe and visit the mercattes, and set ane price on all maner of fishe according to the time, and that they diligenlie inquire gif ony maner of person gives arles, or money, on ony maner of fishe that cummis to the mercat, to the effect that the saimin may be sauld on ane higher price; that they take and punish the saidis persones as coropares, forestallers, and regratoures against the commoun weill."*

And in the same year another Act was passed fixing a uniform measure for the sale of herrings and other fish, which is as follows:-

* 7th Parl., James V., 14th March 1540, sect. 98. 
MEASURES OF FISHE SHUD BE MARKED.

"Item, It is statute and ordained that ane binde and measure be maid for salmounde, herring, and kieling; and that the saimin be kept through all the realme, and that the said measures be conforme to the Actes of Parliamente, and to that effect that ilk cowper have ane burning irone of his marke, to marke ilk barrel, and sic like the town to have ane searchour quhilk sall have the townes marke in keeping to burn ilk barrel swa that our Soveraine Lordis custome thereof be not defrauded. And gif ony fische, salmounde, herring, or keiling, beis founden in sic barrels unmarked, the samin to be escheit, and sic like the tume trees that are, halfe to our Soveraine Lorde, and the utlier to the towne."*

But the most injurious Act appears to be one passed in 1573, which ordains that all the herrings and white fish are to be first brought on shore, and sold in burghs only, namely:-

HERRINGS AND QUHITE FISCHE, SULD BE BROCHT TO FREE PORTES WITHIN THE REALME.

"Item, Forasmeikle as it is heavily complened how that the haill slayer of all kinds of fisches within this realme, not regarding the Actes maid be our Soveraine's -Lordis dearest predecessours of before quhilk is, that quhen herriug and quhite fische is slayne, they aucht to bring the samin to the neixt adjacent burrowes and townes quhair the persones slayers thereof dwellis, to the effect that our Soveraine Lordis lieges may be first served, and gif abundance occurred, that they might be salted and transported be free burgesses: Throw none doing of the quhilk our Soveraine

* 7th Parl., James V., 14th March 1540, sect. 109. 


\section{CHRONOLOGICAL HISTORY OF THE HERRING-FISHERY.}

Lord is greatlie defrauded of his custome, and his hienesse lieges wants the frut of the sea appoynted be God for their nurischment, and the burgesses and freemen of burrowes disappoynted of their trafficque and commorlitie.

" Therefore our Soveraine Lord, with advice and consent of his regent's grace, the three estaites, and haill body of this present parliament, ordains that all maner of fischeres that occupies the sea, and other persones quhat sumever that happenis to slay herring or quhite fische upon the coast, or within the isles, or out-with the samin, with the firthes bring them to free portes there to be saulde commounlie to all our Soveraine Lordis lieges, and the rest to freemen, quhairby his Majestie's customes be not defrauded, and his hicnesse lieges not frustrat of the commoditie appoynted to them be God under the paine of confiscation, and tinsell of the veschelles of them that cummis in the contrair heirof, and escheitting of all their movaluel gudes to our Soveraine Lordis use." *

In the same year another Act was passed fixing the measure of every barrel of herring to be nine gallons of the striveling measure, enacting, "that the coopers shall brand the barrels each with his ain proper marke," as the Act says, "Great sclander sustaines the haill nation throw the default of few number, in so farn as every traffiquer with sic merhandice causis the cowperis make his barrelles and trees of sic quantitie as he pleases."

Smoked or red herrings about this time seem to have been a common article of food, for Montgomery, a celebrated Scottish poet who flourished about 1575 , seemed to think little of the smoked or red herring. His words are :-

"This is no life that I leid up a land

On raw reid lerring reisted in the reik."

* 4th Parl., James VI., 30th April 1573, sect. 60. 
Red herrings seem to have been also in general use in England about the same time. We read that on Maunday Thursday, Cardinal Wolsey washed and kissed the feet of fifty poor people, gave each twelve pence, three ells of good canvass for shirts, a pair of shoes, and a cask of red herrings.*

In 1579 James VI. renews the Act as to the compelling the landing of herring and "quhite fishe," to this effect"That our Soveraine Lordis lieges may be first served, and gif abundance occurred, that they might be salted and transported be free burgesses." This ill considered law must have had a pernicious effect on the fishery at that time, by preventing unlimited sale to other countries. $\dagger$

In 1584 a new Act was passed by King James VI., of

* "Horvit's Visits, p. 260.

$\dagger$ "FOR STAPLING AND TRANSPORTING OF HERRINGS AND QUHITE FISCHE.

"Forasmeikle as divers Actes hes bene maid be our Soveraine Lordis maist nobil progenitoures in time bygane, ordaining that the slayers of lherrings and quhite fisch, suld bring the samin to the next adjacent burrowes and townes, quhair the persones slayeris theirof dwellis, to the effict that our Soveraine Lordis lieges may be first served, and gif abundance occurred, that they micht be salted and transporting be free burgesses. And that the said actes throw negligence and oversights hes nocht received execution.

"Quhair throw our Soveraine Lord hes been greatlie defrauded in his customes, and his hienes lieges wanted the fruit of the sea appointed be God for their nurishment, and the burgesses and free men of burrowes disappointed of their trafficque and commoditie. Therefoir, our Soveraine Lordis, and the three estaites of parliament, ratifies and approvis all the saidis actes and constitutiones, maid anent the saidis herring and quhite fische, and using thereof specialle the Actes maid in the times of umqulile, his hienes dearest Grandschir, King James the Fourth, of gude memory, and be his Majestie the time of the regiment of his richt trest cousing James, Erle of Mortoun, Lord of Dalkeith, Regent to his Hienes, his realme, and lieges for the time. And ordainis all and sundrie the saidis Actes to be observed and keiped in all poyntes after the forme and tenour theirof, and the contraveneris of the samin punisched according thereto. And that the Schireffes, Stewartes, Baillies, Lordes of Royalties, Provests, Aldermen, and Baillies of burrowes, and Judges ordinar, quhatsumever, put the saidis Actes to execution upon the contraveneris thereof. And to that 
a still more objectionable nature, which compelled all those who fished herrings and white fish, to bring what " is slayne be the inhabitants within the water of Forth to Leith, within the priviledge and freedom of the city of Edinburgh, and within the port and haven of Carail ; and what is slayne beneath Fifisness to the water of Dee, to Dundee and Perth; and at the west side to Dumbartane, dividand the bounds at the Clockstane, there to be gaged, marked, and sauld to the free burgesses of the realme," and the most objectionable part is, "that na fischers, or utheris, unfreemens, sell their said herring and quhite fisch to ony stranger, or unfreemen, or carrie the samin forth of the realme, to any uther cuntries to be sauld be themselves, under the paine of escheiting all their muvable gudes.*

effect grantis and givis to them power and commission of justiciare, every ane within the boundes of their ain liberties and jurisdictiones, and to uptake escheittes of the contraveneris being convict, the twa part to the Kingis Majesties use, and to make compt thereof yeirlie in his hienes' checker, and the third part of the samin to the saidis judges executions for their travelle and labours." (6th Parl., King James VI., 20th Oct. 1579, sect. 86.)

* "ANENT the gage AND STANDARD of SALMond, HERRING, AND QUHITE FISH, AND PRINCIPAL STAPLES THEREOF.

"Item, Our Soveraine Lord, with advice of the three estaites of Parliament, ratifies and appreivis all and sundrie Actes and Statutes maid be his hienes and predecessoures concerning the measure of salmond, herring, and quhite fishe, gageing, burning, and measuring theirof. And to the effect the saidis Actes may be the better keeped, and for eschewing of defraud of the saidis measures, and of false and unjust packing of salmond, herring, and quhite fishe, quhilk is meikle used be unfreemen, fischers, and utheris, slayeris of the saidis fish, to the great hurt of the free men, burgesses, and merchandes, and haill commoun weill of this realme. Therefoir, it is statute and ordained that there be ane just measure and standard for the salmond maid be the burrowes, conforme to the auld Actes of Parliament, and the samin to remain at the burgh of Aberdene. And sic like that there be ane just standard and measure for herring and quhite fish, quhilk sall be burnt, and remain in the keeping of the Provost and Baillies of Edinburgh, and that all salmond trees, herring trees, and quhite fishe trees, 


\section{CHRONOLOGICAL HISTORY OF THE HERRING-FISHERY. 151}

In the following year, however, it appears that this last mentioned Act had been found injurious, and was objected to, as to the restriction to certain burghs where only the herrings could be graithed or handled, for another Act was passed permitting the fish to be brought to any of the free burrowes:-

\section{FISH SLAIN ON UTHER SIDE OF THE WATER OF FORTH MAY}

\section{BE BROCHT TO ONY FREE BURGH.}

"Forasmeikle as in the Act of Parliament lately maid anent the packing and peiling of herring, and quhite fish,

universallie throw this realme, sall be of the gage and measure foresaid; and that ilk burgh sall receive ane patrone and measure of the gage foresaid, and sall cause the cooperes within their boundes make their trees conforme to the said measure, and the same to be burnt be the town iron, and couppers iron, on baith ends, and upon the steppe beside the bung. And in case ony salmond, herring, or quhite fish be packed in utheris trees, nor of the just gage foresaid, burnt and marked as said is, the samin sall be escheit to our Soveraine Lord. And ordainis the principal staple of salmond fra Dee north, to be at the burghes of Aberdeen and Elgine, and the principal staple of herring and quhite fish, slaine be the inhabitants within the water of Forth, to lie in Leith, within the priviledge and freedom of the city of Edinburgh, and within the port and haven of Carail. And the staple of salmond, herring, and quhito fish, slayne be north Fifisness, to the water of Dee, to be at Dundee, or Perth. And that the saidis Provest, and Baillies of Edinburgh, Aberdeen, Carail, Elgine, Perth, and Dundee, sall appoynte ane discreet man to be visitour, wracker, and gager, and burner of the saidis trees, and appoynte to him ane reasonable duty of ilke last thereof for his labours. That all unfreemen, fischers, and slayers of herring and quhite fish, dwelland within the boundes of the water of Forth, on baith the sides to the water mouth of Tay, bring the herring and quhite fish to be slayne by them in time cnmming to the portes of Leith, or Carail, and at west side to Aire and Dumbartane, dividand the boundes betwixt, at the Clockstane, there to be gaged and marked, and sauld to the free burgesses of this realme. And that na fischers, or others unfreemen, sell their said herring and quhite fish to ony strangers, and unfreemen, or carrie the samin forth of this realme, to ony uther cuntries, to be sauld be themselves, under the paine of escheiting of all their moveable gudes: the ane half to our Soveraine Lordis use, and the uther half to the burrowes qua sall convict them be vertue of their commissiones." (King James VI., 8th Parl., May 22d, 1584, sect. 141.) 
and uther fish slaine on uther sides of the water of Forth, it is expreslie provided that all the saidis fishes sall be brocht to the porte of Leith and Carrail allanerlie: There to be graithed and handled as in the said Act at mair length is contained. Quhilk sinsine lies bene very hurtful and prejudicial to the remanent free burrowes and sea ports on uther side of the said water of Forth. Therefore our said Soveraine Lord, with advice of his three estaites convened in this present Parliament, declaris, statutis, and ordainis, that it sall be leasum to the remanent of the said free burrowes to have the saidis fishes brocht to ilk ane of them in time cumming, alsweil, as to the saidis portes of Leith and Carrail. Notwithstanding ony restriction maid thereanent be the saide Acte or uther ways of befoir, dispensand therewith for ever. And ordainis letters of publication to pass hereupon in forme as effeiris."*

We have an amusing account of the excitement occasioned among the superstitious of all ranks in 1587, in consequence of marks on two herrings fished on the 10th November of that year off the coast of Norway, which seemed to exhibit words in Gothic letters. They wero brought to Copenhagen, and seven days after their capture presented to King Frederick the Second, who was terrified at their appearance, and thought they predicted his own death. He consulted the wise men of the age, who read the letters, and said that they were the following very innocent, and at present true prophecy, "You will not fish herrings in future so well as other nations." But this interpretation did not satisfy the king, and he applied to the learned men of Rostock; but neither the professors there, nor at several of the universities of Germany who were consulted, could give a satisfactory

* 10th Parl., King James VI., 10th Dec. 1585, sec. 114. 
interpretation of the prophetic budget carved out on the backs of the two ominous fishes; but a learned French mathematician, then at Copenhagen, published a large volume in elucidation of the supposed words. This work would be a curiosity if it were found, as we are not informed what his interpretation was. Another author published his opinions, to the effect that the supposed letters announced the subversion of all Europe.*

In 1587 the fishery of herrings in the North Highlands had been extensive, for a law was passed in that year, ordering that the "customares and searchers sall take inquisition, and note quhat quantity victual every schip or vessel takis in at her passing to Loch Broom and utheris the North Isles and loches in the harvest season in fishing, and take souerty that they shall returne the third part of their lading of hering or quhite fish, to be sold to our Soveraine Lordis' lieges for their sustentation and furnishing of the cuntrie, under the paine of one hundred pounds." The act is as follows :-

ANENT VICTUALLING OF SCHIPPES PASSING TO THE NORTH FISHINGS, AND CAUTION TO BE FOUND FOR THEIR RETURNING.

"Item, Our Soveraine Lord and lis three estaites, convened in this present parliament, statutis and ordainis that the customares and searchers sall take inquisition, and note quhat quantity victual every schip or vessel takis in at her passing to Loch Broome and utheris the North Isles and loches in the harvest season in fishing; and take souerty that they shall returue the third part of their lading of hering or quhite fish within this firth or other free burrowes, to be sold to our Soveraine Lordis

* Cuvier et Valenciennes, Nat. Hist. des Poissons, vol. xx. p. 71. 
lieges for their sustentation and furnishing of the cuntrie, under the paine of ane hundred poundes." *

In 1600 another objectionable Act was passed, prohibiting the exporting of herrings before Michaelmas (Old Michaelmas, 11th October), and ordering that the herrings be brocht to public marcets, and their sauld to all his hienes' lieges upon reasonable pryces." $\dagger$

About this time King James VI, before he went to England, endeavoured to establish a fishing colony at the Lewis Islands, and an expedition proceerled thither for this purpose commanded by William Murray, Learmonth of Balcomy, James Spence of Wormwood, Sir James Anstruther, and James Forrest of Fingask. The copartners had agreed to get possession of the Lewis for 140 chaldrons of barley, and took 600 men with them and several geutlemen as volunteers. They had, however, to contend with Mardoc M'Leod, who then commanded there, but who was ultimately compelled to enter into a

* 11th Parl., King James VI., 29th July 1587, sect. 57.

† ACT ANENT THE SALTING AND TRANSPORTING OF HERRING.

"The Kingr's Majesty, with advyse of the estaites of this present parliament, statutis and ordainis that na person or persones, als well strangers as native borne subjects of this realme, take upon hand to buy, pack, peill, salt, barrel, or yet transport foorth of this realme any herring, in small or great quantity, at any time before Michaelmas yearly, but to suffer the samine to be brought to public marcets, and there sauld to all his hieness' lieges upon reasonable pryces, without attempting anything in the contraire thereof, under paine of confiscation of the samine to the apprehender, and the rest to his Majestie's use, to be intromitted with by his hienes' comptroller, and sik as he shall give power and commission to for that effect; and statutis and ordainis that no licences be granted hereafter for packing, peiling, salting, and transporting of herring before the time foresaid, except the samine liecences be granted with consent of the counsell sitting in the counsell. And after granting of the said licences, ordaines the saimine to pass the signet and haill seals, otherwise declares the samine licenses to be null and of no avail." (King James VI., 16th parliament, 15th November 1600 .) 
treaty. M'Leod afterwards left the district, and when Learmontlı of Balcomy was on his return to report the success of the expedition, he was attacked by $\mathrm{II}^{\prime} \mathrm{Leod}$, his men killed, and he himself made prisoner and detained, M'Leod demanding a ransom. Learmonth died in the Orkneys; and ultimately, M'Leod and twelve of his followers were taken and executed at St Andrews.

In 1602 the commissioners of England and Scotland agreed that the fishing within fourteen miles of the shore of Scotland, "where neither English nor other strangers used to fish," should be reserved to the Scotch.*

In the year 1605 the attempt to establish a colony of fishermen at the Lewis Island was repeated. The company before named transferred their right to Lumsdale of Airdrie and $M r$ Hay, who, getting aid from $M$ 'Kenzie and Donald Gorm, compelled the M'Leod of that time and his followers to leave the island, and got people from the south to erect houses and an establishment; but as the funds became exhausted, they sold their right to M'Kenzie, and the enterprise was then given up.

In October 1609, King James VI. issued a proclamation prohibiting foreigners from fishing on the coasts of Great Britain, and, accordingly, the following year, the Dutch made a treaty with him, agreeing to pay for liberty to fish in the British seas.t

In 1613 a composition was made for the usual supply of fish to the king's household by Great Yarmouth, namely, annually to supply 1500 cods and 60 barrels of white herrings, of the lest brand, at the price of $13 \mathrm{~s} .4 \mathrm{~d}$. per barrel, and 10 casks of full red herrings, of one night's

\footnotetext{
* Spottiswoode's History of Scotland, p. 483.

† Salmon's Chronology, vol. i. p. 96; Anderson's Commerce, vol. i. p. 478.
} 


\section{CHRONOLOGICAL HISTORY OF THE HERRING-FISHERY.}

death, at the price of $6 \mathrm{~s} .8 \mathrm{~d}$. per cask; the supply of cod to begin in August, and of herrings in December.*

Charles I. seems to have been anxious to encourage the fishery, and under his auspices the Earl of Pembroke fitted out several busses, but unfortunately they were principally taken by the Spaniards, and the crews imprisoned, who had to be ransomed at high rates, and the earl, in this spirited enterprise, it is said, lost about L.50,000.

There appears to liave been "past memory of man" a tax or duty paid by foreign ships coming to Orkney and Shetland, or to the coasts of the different islands, for a remonstrance having been made by the republic of Bremen against Sir James Stewart of Kilsyth, then farmer of the Isles of Orkney and Shetland, as if he had imposed higher duties than usual upon the ships and goods of the inhabitants of that town, the same was remitted by the king to the Privy Council, and their decision was as follows:- "The Lords of Council having heard and considered all that was proposed and alleged by both the said parties in this matter, and understanding that the foresaid toll-duty of six angels and a dollart of every stranger ship arriving within the said bounds of Orkney and Shetland, has been thankfully and willingly paid, past memory of man, to the Earls of Orkney of the time; and that count has been made to his Majesty's Exchequer, as being a part of the proper rent and patrimony of the earldom of Orkney and Shetland. Therefore the said Lords ordain the said toll and duty of six angels and a dollar, of every stranger ship arriving within the suid bounds, in their lawful trade to stand, and be paid to his

* Swinden, p. 117.

† The angel was a gold coin equal to the half mark, or $6 \mathrm{~s} .8 \mathrm{~d}$., and the dollar, 4s. 6d. 
Majesty, and his successors, their comptrollers, chamberlains, and factors, in their name, in all time coming; aud touching the custom craved from the said strangers for the commodities exported and imported by them, the said Lords understand that the said customs properly belong to his Majesty, and that all foreign princes, within their dominions, have the freedom and privilege of customs as a royal prerogative, and that no person, stranger, or native subjects, can, with reason, crave an immunity and freedom from payment of customs: Therefore, the said Lords ordain the customs to stand, and to be paid, in all time coming, to his Majesty, his comptrollers, and officers, and touching all other tolls and duties craved of the said strangers, the Lords discharge the same simpliciter; discharging the said Sir James Stewart of all asking and uplifting the same."*

That the Scottish ration, in former times, fully understood and asserted their right to the fishery on their coasts is evinced by the Records of the Privy-Council of Scotland. Thus, in 1619, a commission was passed under the Great Seal of Scotland, appointing Mr John Fenton to repair to the North Seas of his Majesty's kingdom, and there, in his Majesty's name, to ask and receive from those of Holland, Zealand, Hamburgh, Sweden, and Rostock, and from all other strangers haunting the trade of fishing in his Majesty's said seas, this present year, his Majesty's rent of assize and teind of the hail fishes taken, or to be taken, by them, in his Majesty's said seas and waters, of this present year, counting his Majesty's assize duty to 10,000 herrings for every buss of herrings, and a last of white fish for every buss of white fish, or else to receive from them the sum of $13 \mathrm{~s} .4 \mathrm{~d} .,+$ usual money of this king-

\footnotetext{
* Priry-Coun. Reg., June 30, 1614. † L.1 Scots is 1s. 8d. English.
} 
dom, for every thousand of the said assize herrings, and L.50 money of this kingdom for every last of the said assize white fish, and accordingly for every thousand teind herring, and for every last of the teind white fish.*

Instead, however, of the Scottish fleet having been permanently engaged in getting "teinds and assize," it seems tohave been othorwise employed, for it was not even occupied in protecting "the poor fishers in Scotland" in 1625, for, on the 25th of September of that year, a letter from the Lords of the Council was sent to his Majesty, relating to "the great abuses done by the busses of the low countries" in fishing along the north and east coasts of Scotland, to the utter ruin of all the poor fishers in Scotland, and "prejudicing the hail kingdom of the benefit of herrings." $\dagger$

In 1630 King Charles issued a commission to inquire into the fishery of the British coasts, and how the same might be rendered more beneficial by forming a general fishing company, and at the same time sent "a missive letter" and "instructions" to Sir William Alexander, Sccretary of State for Scotland, at Edinburgh, dated Westminster, 12th July 1630, which are of sufficient importance to be given at length. The records state as follows:-

"1630, July 30.-The which day Sir William Alexander, knight, his Majesty's Principal Secretary of State in this country, exhibited and gave notice, and he states his Majesty's missive-letter underwritten, together with the instructions given by his Majesty to the said Sir William, to be treated by him with the said estates about the erection of a general fishing, of which missive-letter and instructions the tenor follows:-

\footnotetext{
* Privy-Council Records of Scotland, 29th June 1619. $\dagger$ Privy-Council Records, Book 26.
} 
CHRONOLOGICAL HISTORY OF THE HERRING-FISHERY, 159

"Charles R.

"Right trusty and well-beloved cousin and councillor, and right trusty and well-beloved councillors, We greet you well. Having, with the advice of our council here in England, materially considered that, as well in thankfulness to Almighty God, as for the benefit of our loving subjects, we ought no longer to neglect that great blessing offered to us, in the great abundance of fish upon the coasts of our islands; to the end we may at length enjoy, with mare honour, those riches which properly belong to our imperial crown, and are usurped by strangers, we have considered of a way which in time, by God's favour, may produce this effect, and also increase our navigation and trade; and because this work concerus equally our three kingdoms, and must therefore be undertaken and ordered by common councils' assistance, we have taken this opportunity of our convention, at Edinburgh, to send our instructions to Sir William Alexander, Secretary for Scotland, to acquaint you with certain proportions for the advancement of this service; and we require you both to give him hearing at large, and freely to treat with him, in every point of his instructions, and in whatever may be found expedient for the furtherance of so good and great a work, concerning both our honour and the public good; and withal we expect that you proceed not only to a resolution upon such articles as shall be agreed upon, but that you also put them in execution, so as, by him, we may specially understand how you take it to heart, and how far you concur for the accomplishment of the work; wherein you may expect from us such privileges and powers as shall be convenient, and as reasonable as you can desire; and also be assured we shall graciously accept your extraordinary care and forwardness 
in a business which, with extraordinary earnestness, we recommend to you.

"Given at our Palace of Westminster, the 12th day of July 1630.

"By his Majesty's commands.

(Signed) "Joнn CoкE."

"Instructions for Sir William Alexander, our Secretary of State for our kingdom of Scotland, employed by us to treat with the Lords of our Privy Council there, about the erection of a general fishery :-

"First, You are to signify to the said Lords, and others of our Council in Scotland, that having duly considered how great a blessing God hath given our kingdoms, in the abundance of sea fish upon all our coasts, and how the benefit thereof is reaped only by strangers, to the great disparagement and prejudice of our loving suljects, we have now taken a royal and firm resolution to set up a common fishery, to be a nursery of seamen, and to increase the fishery and trade of all parts of our dominions, and this being a common benefit to all our three kingdoms, so as they cannot be dividedly enjoyed by any.

"Our royal and gracious pleasure is to have it undertaken and ordered by common council and adventurers, and to that end (among other things, we have sent you to this meeting of the Lords of our Council at Edinburgh, there to make this intimation), and to represent to them the propositions which have been offered and approved of here, tending to the advancement of this great work, that they may be taken there into the like serious consideration; and as well to ratify, and confirm what they shall agree upon, and advise what other ways and means may conduce to the perfecting thereof; and because a great 
stock must be raised in contribution of adventurers, who cannot otherwise be drawn into it, but by hope of great and present gain, you are to show to the said lords the estimate of the charge and profit, which being too long to insert here, and the profits of the fish less than they were in these days, shall only take notice that the charge of one hundred vessels was computed at L.72,000, and the fish taken in one season is rather computed at too much, in my opinion, as they are reckoned to come to L.100,000, so that there is L.28,000 got clear in one season, besides the vessels."

The king began to be aware of the propriety of protecting the coasts, for he sent a message to the Earl of Stratherne, to be communicated to the Privy Council of Scotland, "that they give orders for the removing of all strangers repairing to our coasts for fishing, and others trading without license;" this was on the 13th August, 1632.

In June 1633, Mr Smith was sent by the Earl of Pembroke to Shetland, to inquire as to the herring-fishery carried on in that neighbourhood; and this gentleman says in his report: "I was an eye witness of the Hollandes busses fishing for herrings on the coasts of Shetland, not far from Unst, one of the northernmost islands. I was informed that the fleet consisted of fifteen hundred sail, and that there were twenty waffters, as they called them, which were ships carrying about twenty guns each, being the convoys of the fleet of busses, which said busses were of the burthen of about eighty tons." *

In the same year Charles I. granted a charter, with many privileges, to a new company, for the purpose of cstablishing a fishery at the Hebrides; the undertaking

* Smith's England's Improvement, revised, 257. 
was supported by the Duke of Richmond, the Earl of Pembroke, Lord Southampton, Sir William Monro, and others of distinction, and aided by the Privy purse. King Charles enjoined Lent to be more strictly observed, and agreed to purchase the fish for the navy from this company. Several magazines for storing casks and salt were built in the Hebrides, onc in Harris, and another at Lochmaddy, in North Uist, but the civil wars ensuing, the Danes and Dutch attacked the new colonies, and the undertaking was thus prevented; the sufferers afterwards petitioned Charles II. for redress, and stated that they had sustained losses to the extent of L. 300,000**

In the year 1633, Mr Dick, merchant in Edinburgh, farmer of the Isles of Orkney and Shetland, received from his sub-collector at Stronza, a small port of the Orkneys, the sum of L.858, Scottish money, as the teind duty of thirty-two Dutch doggers, thirty paying L.27 each, and two L.24 each.

In 1636 King Charles issued a proclamation prohibiting all persons, not his natural born subjects, from fishing on the coasts and seas of Great Britain and Ireland, without a special license first obtained from his Majesty, and accordingly the Dutch agreed to pay L.30,000 for liberty to fish that summer. $\dagger$

In the year $1642 \mathrm{Mr}$ Dick again accounted for teinds from the same port of Stronza, L.507 for eighteen Dutch doggers, and two busses, proceeding to the fishing.

In 1654, a new company in London endeavoured to renew the fishery at the Hebrides, but Cromwell destroyed their forts at Stornoway, and built new ones to restrain

* Rymer's Foodera, vol. xx. p. 20.

+ Rusheworth Collection, 322 . 
the inhabitants; but his garrison was also destroyed, and the fishery was again abandoned.*

Some four months after Charles II.'s restoration, and in 1661, he wrote a letter to the Lord Mayor of London, recommending the city of London to fit out busses for fishing herring; and on the 23d of August, a commission was issued under the Great Seal, by King Charles II., appointing his Royal Highness James Duke of York, Lord Clarendon, and several others, to be a Council of the Royal Fishery of Eugland, Scotland, and Ireland, which society, thus encouraged by the sovereign, endeavoured to renew the herring-fishery in the north of Scotland, and raised funds by way of lottery, and by public collections; and Dutch families were invited to Stornoway as settlers.

In this year also King Charles II. renewed the prohibition as to foreigners fishing in the British seas, and it is stated that the Dutch agreed to pay L.10,000 per annum for this privilege.

On the 1st January, in the year 1661, the Scottish Parliament, on the suggestion of Charles II., passed an Act for the purpose of encouraging the establishment of fishery companies; it is entitled, "Act for fishing, and erecting of companies, for promoting of the same." The preamble proves the high anticipations of the promoters of it. The Act begins thus: "Our Sovereign Lord, considering the best and readiest means for improving the benefit and advantages which properly belong unto him by the fishes which are, or may be, taken within the seas, channels, firths, and lochs adjacent, and surrounding this his ancient kingdom, and perceiving the same may be of great advantage many ways, especially in that the said trade will not only be a nursery for seafaring men, and a

* Knox's Observations on the Northern Fisheries, p. 18. 
164 CHRONOLOGICAL HISTORY OF THE HERRING-FISHERY.

speedy occasion of building ships for his Majesty's and his subjects' use, both in peace and war, but likewise will set many poor and idle persons awork, and furnish the materials of a great native export, for the continual enriching of his Majesty's kingdom, by a sure foundation of trade and commerce." And it accordingly authorises the erection of corporations, each member admitted to which shall pay not less than one hundred merks into the funds; that the company, or companies, "shall have full powers to fish" herring, or white fish, "build houses and little cottages," to make laws and regulations, and to constitute councils and courts to decide in all matters regarding the fishery, and none was to be of the council who did not subscribe at least one thousand merks; that his Majesty, "out of his innate beneficence, and royal bounty, ordained that salt, cordage, hemp, cork, pitch, tar, clapboard, knaple, skewlioops, and Holland nets, imported by said companies, should be free of duty;" that such herrings should be "free of any manner of taxation or burden" on exportation; that "strange fishers," who came to reside in Scotland, should be, on the application of said companies, naturalised, and free of any taxation for the space of seven years; released and discharged the said company of the teind herring, and the excise herring, due to his Majesty (except the herring of Dunbar), for the space of nine years; "freed" the beer, strong waters, and other provisions, for outfitting of any vessel, of all duty; charging all proprietors of lands to protect said companies and their people, and discharging them from exacting more than twelve shillings Scots (1s. English), per last of twelve barrels in full of all dues; and declares the ships, boats, vessels, and people, free of detention, arrestment, or caption, during the time of fishing. 
The objectionable parts of this otherwise liberal enactment are, that no herrings taken by Scotsmen, not belonging to the companies, were to be sold to any but natives; that the return from foreign places was to be sold only " in free burghs to free burgesses, provided they do not retail by selling less quantites nor five tun of wine, or the equivalent in value;" but the only great error in this Act was the erecting of companies and placing the funds at the disposal of managers and council. The following is the Act in question :-

' $A$ CT FOR FISHING AND ERECTING OF COMPANIES FOR PROMOVING OF THE SAME.

' Our Sovereign Lord, considering the best and readiest ' means for improving the benefit and advantages which 'properly belong unto him, by the fishes which are or ' may be taken within the seas, channels, firths, and 'lochs adjacent and surrounding this his ancient king' dom; and perceiving the same may be of great ad'vantage many wayes, especially in that the said trade ' will not only be a nursery for seafaring men, and a 'speedy occasion of building ships for his Majestie's ' and his subjects' use, both in peace and war, but, like' wise, will set many poor and idle persons awork, and ' furnish the materials of a great native export for the ' continual enriching of his Majestie's kingdoms by a sure ' foundation of trade and commerce; for which ends, and ' that the said trade of fishing may be the more effectually ' advanced and promoved within this his Majestie's ancient ' kingdom; his sacred Majesty, with consent of his estates ' now conveened in this present Parliament, hath erected, ' and by the tenour hereof erects, and creates, and estab' lishes particular societies and companies of his Majestie's 
" free-born naturalised inhabitants of Scotland, and of all ' others who shall be taken and enrolled in any of the 'said companies and societies, and admitted to the privi' leges thereof, and shall enter themselves in the said so' cieties within any shire or burgh of this said kingdom, 'one or moe betwixt and the

' day of ; as the first modern societies or ' companies to the effect after specified, constituting and 'creating such persons who shall enter themselves and ' their successors in a body and incorporation politick to ' exercise the trade under-written: And ordains that none ' be accepted therein, except he who shall enter the sum ' of five hundred merks Scots, at least, of stock in the said 'society: And wills and grants that whosoever are of the ' forsaid societies or companies to be constitut, their heirs ' and assignees, shall enjoy the yearly benefit of the stock " to be given by them in all time after the ingiving there' of, but to have no power to uplift the stock, except by ' consent of the companie or council thereof after-specified, ' granting and committing like as his Majestie by the "tenour hereof gives, grants, and commits to the said ' companies and societies so to be constitut, and to all ' such whom they or their successors shall admit or re' ceive therein, full power to take and fish herring and 'white fish in all sundry seas, channels, firths, rivers, 'floods, lakes, and lochs of this his Majestie's said ancient ' kingdom of Scotland and isles thereuntobelonging, where-

'soever herring and white fish are or may be taken, and 'to bring' in and disburden the said herring and other ' white fishes to all and sundry ports, harbours, shores, ' and to lay the same on the land, and pickle them with ' salt, and to dry and load the same in barrels and pun' cheons, and for conservation of the said herrings and 
' fishes; to build houses and little cottages, and other ' things necessary for the use of the said fishery trade in ' whatsoever places shall be convenient, upon the pay' ment of the allowance under-written, unto the lord or ' master of the ground or otherwise ; to sell, use, and dis' pose upon the said herrings and other fishes to the in' habitants, or to keep and conserve the same in their 'ships and boats, and so make and prepare them therein; ' and to carry and transport the same to foreign parts be' yond seas in ships and other vessels belonging to them 'or his Majestie's other subjects, and to sell, use, and

' dispose thereupon to such who shall be in friendship ' and amity with his Majesty and his suecessors; with ' powver also to the said companies and societies respec' tive to elect and make choice of such of their own num'ber as they shall think fit for making and framing of ' laws, statutes, and rules, for the right regulating, manag' ing, and carrying on of the same trade of fishing, the ' said laws being always aproven and allowed by the

' Council of Trade, and to punish transgressors accordingly,

' and that they be Scotsmen or naturalised strangers, and 'residents within the said kingdom, and to the which ' Council so to be nominated, constitute the said companies ' respective shall submit, and to all their acts, statutes, ' and rules especially, but prejudice of the generality ' foresaid, to the particular rules under-written. To wit, ' First, That none after the erecting and setling of the ' said companie or society may enter or come in but by ' consent of the company or council thereof, after the said ' day of next, except they be ' appointed or enrolled and taken by the Council of Trade, ' to whom any person, in case of exclusion, may make his 'address. Secondly, That the return from foreign places 
' upon the stock may be all sold in free burghs and to free ' burgesses within this kingdom by the said companies, 'or any of them or their factors, without any previous ' offer to the burgh, provided they do not retail by selling ' quantities, under five tun of wine, or the equivalentin value ' in other commodities which shall only be sold in whole' sale, without any retail whatsoever. Thirdly, That no ' herring or white fish taken by Scotsmen in the said ' kingdom or isles thereto belonging, be sold fresh or salt ' to any, but to natives, except by the companies respect' ive, and that no strangers unnaturalised shall have liberty ' to make or prepare herrings or white fish upon the land, ' or to make boths for that effect, under the pain of con' fiscation of what seized upon, and the double thereof to ' be exacted off the seller, except they be free of one of ' the companies forsaid; with power also to the said coun' cil to use and have a seal or gage for ilk company re'spective, wherewith all their barrels or puncheons may 'be marked; and that ilk barrel of green fish contain 'twelve gallons, which is to be the ordinar gage betwixt ' buyer and seller; and also to make use of and employ all ' and sundry tolbooths and warding-houses where neces' sity requires, for holding of courts, warding, or punish' ing of transgressors, the burghs being always free of the ' charges of the prisoners; and, further, to depute such of ' their number as they think fit concerning all businesses ' and affairs, and to cognosce and determine in all ques'tions and debates relating to the said trade of fishing, ' and to cause execute such decrees and sentences as shall 'be pronounced thereupon; and for that effect to make ' choice of officers and servants, and to administer oaths 'to them, and amongst themselves, for the good of the 'trade, and, if need be, with power to the said council to 
' design certain judges under them in convenient places to 'administer justice in the matter of the trade fishing. ' allenarly: And our sovereign Lord being willing to ' cherish and encourage the forsaid societies and com'panies in the said trade, hath, out of his innate benefi' cence and royal bounty, ordained, and by the tenour ' hereof discerns and ordains that salt, cordage, hemp, ' cork, pitch, tar, clapboard, knaple, skewhoops, and Hol' land nets, imported for the trade of fishing foresaid, by ' the foresaid companies respective, are and shall be ' free of any custome or other imposition whatever; ' and that the herring and white fish taken, made, ' or prepared therewith, are and shall be free of any ' manner of taxation or burden in the exportation of 'the same. And also, that all strangers fishers, who ' shall repair to this, his Majestie's ancient kingdom, and ' will come and make their residence within the same, ' shall be naturalised by his Majestie upon the desire and ' application of any of the said councils, and shall be ' entered burgesses in any city where they shall reside, and ' shall be freed of all manner of taxation, for the space ' of seven years next after their arrival. And further, his - Majesty hath releaserd and discharged, and by the tenour ' hereof impliciter releases and discharges the teind 'herring, and teind fish, of all such horring and fish "which shall be taken by the boats and fishers of 'the said companies respective, or such who shall be ' hired by them in all time hereafter; and also exoners ' and discharges the excise herring due to his Majestie ' (except the herring of Dunbar) for all the days, space, 'years, and terms, of nine years next after the date ' hereof; and in like manner his Majestie declares that all ' ale, beer, strong' waters, and other provisions for the out 


\section{CHRONOLOGICAL HISTORY OF THE HERRING-FISHERY.}

' reeking of any vessel for the said fishings of the said ' companies, is and shall be free of all manner of imposi'tions whatever; commanding hereby the lords and ' masters of the ground, in all places through the said ' kingdom where there is loch or other fishings, not only 'to protect, maintain and defend the said company and 'society, and all masters of ships, fishers, and others ' whatsoever, going about the said trade, and belonging 'to the respective companies of fishing, from all harm, ' trouble, or damage whatsoever, or else to satisfy and re' fund their loss and damage which they shall sustain ' upon their land, but also that they nor none of them ' presume nor take upon hand to exact or levy any more

'from the said fishers, merchants, or their servants be' longing to said companies for ground leave, but ' only twelve shillings Scots for every last, and that in ' full satisfaction of the Saturdayes fishing, or any manner 'of dues whatsoever; and for the greater encouragement 'of merchants, fishers, masters of ships, and other vessels ' and their servants, to attend the said trade of fishing, ' his Majestic by his sovereign authority and prerogative 'royal, not only by these presents declares the ships, ' boats, and other vessels with their furniture provided ' for, and in exercise of the said trade of fisling, no 'ways to be arrestable by any creditor, but that the ' same and those that shall serve them shall be free from ' all actions, and no ways conveenable before any judge ' judicatory whatsoever, for any cause or causes civil, ' which may be intended against them, but also by the 'tenour hereof, declares the said fishers, masters, and " their servants above written, shall be free of captions, ' arrestments, or other attachments, on their persons or ' against their materials and instruments of fishery dur- 
' ing the time and season of fishing, they being actually ' serving therein allenarly. And further, that none who "shall be upon council or any of the sureties of trade ' foresaid, shall be liable to less stents or taxation, for ' what stock they have entered, or shall enter in the said ' companies or societies respective, or for the benefit or " profit arising thereby in time coming. And it is hereby ' declared, that it shall be licent to any of the council or ' societies of said trade of fishing respective, for the good 'thereof, to dwell and reside in any part or place of his ' said kingdom, albeit they be burgesses in any burgh ' royal, and not thereby loss their freedom, notwithstand' ing of any act or acts in the contrare. And in like ' manner it is hereby declared, that no person nor persons ' shall have liberty to export herrings or fish, nor shall ' use and have priviledges, liberties, immunities, above ' written, but those that shall enter themselves and be ' free in one or other of the said companies and societies. 'And finally, it is hereby statute and ordained, that those ' in the several shires and burghs of this kingdom, who ' shall enter in the said companies and societies, conform ' to the tenour of this present Act, shall give an account 'thereof to the parliament, or his Majesties council of 'trade for the time within after the erection 'thereof, that the same may be recorded, ad futurum Rei

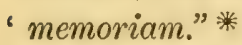

On the 17th November 1663, at a meeting of the privy council, the Duke of York being present, Sir Richard Chaterton, Sir William Batten, and Sir William Ryder, were appointed by his Royal Highness as the council to meet and draw up proposals for the formation of the 
Royal Herring-Fishery; and they accordingly met, attended by three gentlemen well acquainted with the subject ( $\mathrm{Mr}$ Simon Smith, Mr John King, and Mr Thomas King), and measures were arranged for prosecuting the undertaking with vigour, and it was then proposed to adopt the Dutch herring-fishery laws; and the Royal Fishery Company was ultimately established. The stock of the company amounted to L.11,000, and they fitted out seven busses in Holland; but unfortunately the French, in 1677, took six out of their seven busses, with their cargoes, and in July 1680 the company sold their remaining ship and stores; but in 1681 the subject was again revised, and a capital of L.60,000 was subscribed for the purpose of renewing the fishery, but without much success.*

About this time however, the herring-fishery seems to have been prosecuted with vigour on the coast of Scotland; II'Ure in his "View of Glasgow" (page 206), says "Walter Gibson one year made, packed, and cured, 300 lasts of herrings, (1) L.6 stg. 79 last, containing 12 barrels each last; and having freighted a Dutch ship called the "St Agati," burdened 450 tons, the ship with the great cargo arrived safely at St Martins, in France, where he got for each barrel of herrings a barrel of brandy and a crown; and the ship at her return was loaded with salt and brandy, and the product came to a prodigious sum, so that he bought this great ship and other two large ships." And from a MIS. of Sir Robert Sibbald's, in the Advocate's Library, quoted by Dr Walker, it appears that 600 boats, with above 4000 men, had been seen at one time employed in the herring-fishery of the Clyde, which afforded about 3750 tons for exportation; and it is also stated that one

* John Collins on Salt and Fishery, 1681, pp. 2 and 57. 
or two towns on the coast of Fife fitted out 168 boats, manned by 1120 men, and generally exported 12,000 barrels.* And an author who wrote a work on "Salt and Fishery," says the Scotch boats every year carry away from Dublin L,60,000 sterling for salt and herrings. $\dagger$

The undertakings which had been begun in London seem to have been unsuccessful, for on the 25th September 1684, letters patent under the great seal were granted by King Charles II., incorporating a company for carrying on the fishery, to be called the "Royal Fishery of England," but the sum subscribed amounted only to $£ 11,980$; and in consequence of the death of Charles II., the new company which had been formed was dissolved, and it is alleged King William did not sufficiently encourage the fishery, from a desire to protect his countrymen the Dutch. In what way King William did so it does not appear, unless, in his well-known penurious disposition, refusing to furnish funds for another undertaking. An Act of Parliament was, however, passed in 1690, having the following preamble, which proves the necessity of legislative interference, for although the company had discontinued fishing, they still continued to exact 10s. per last on all herrings exported. This preamble says, "Considering that the late Royal Company erected for fishing is now dissolved, by returning their stocks and quitting the prosecution of that trade in company as was designed in its institution, and yet they continue to exact six pounds Scots per last of all herrings exported forth of the kingdom, to the hurt of their Majesties' lieges," it then goes on to annul the former Act, allows a drawback on the salt used of ten pounds four shillings Scots on all herrings exported; but while it

* Transactions of Highland Society, vol, ii. p. 295.

$\dagger$ John Collins on Salt and Fishery, p. 67. 


\section{CHRONOLOGICAL HISTORY OF THE HERRING-FISHERY,}

allows all the lieges to fish, it prohibits exportation except by the merchants of the Royal Burrows.* This act is as follows:-

\section{'ACT ANENT THE FISHERY.}

'OurSovereign Lord and Lady, with consent of the estates ' convened in Parliament, considering that the late Royal ' Company erected for fishing, is now dissolved by retir" ing their stocks and quitting the prosecution of that ' trade in company, as was designed in its institution, and ' yet they continue to exact six pounds Scots per last of ' all herrings exported forth of the kingdom, to the hurt ' and prejudice of their Majesties lieges: Therefore their 'Majesties, with the advice and consent of the estates of ' parliament, do rescind, reduce, and annul, the foresaid ' gift of erection of the company, called the Royal Com'pany of Fishing, with the whole priveledges and im' munities belonging thereto, together with all acts, con' firmations, and ratifications thereof, and declares the ' foresaid company to be dissolved; discharging hereby, ' and strictly prohibiting the exacting of the six pounds 'Scots for the last of herrings, or any other imposition, ' or exaction upon herrings, or any other fishings what"somever, on the account of the foresaid company, or ' any having their right, from the takers or importers of ' herring, salmon, and white fishes, or any other fishes in ' all time coming. And for the further encouragement of ' the trade of fishing, their Majesties, with advice and ' consent foresaid, do allow, invite, and encourage, the ' merchants of the royal burghs, and others of their good ' subjects, to employ their stocks andindustry in the trade of ' fishing and curing of herring, in which they shall enjoyall * William and Mary, 25th April 1690, 1st Parl. 2 d sect. cap. 34. 
' the freedoms and advantages competent to them, before

' the erection of the foresaid company, and particularly ' the foreign salt, imported and employed upon the curing ' of fish, shall be free of excise or other duty. And to ' prevent all questions that may arise anent the quantities " of salt to be employed, their Majesties, with advice ' and consent foresaid, do ordain the merchants exporters 'to have allowance, or to be repayed, by the customers for 'behoof of first seller and curer of the fish, who bought ' the salt for that use, of ten pounds four shillings Scots, ' for the salt of each exported last of herrings, conform to ' the twelth act of the first session, of the second Parliament ' of King Charles the second, anent excise and customs, ' and the proclamation of the Privy Council, dated the ' eleventh day April, one thousand six hundred and ' thirty-one, instead of the exemption of customs of all 'fishes exported, provided by the first Act of the fourtl 'session of that same Parliament, anent the pre-exemp'tion of salt. It is hereby expressly provided and de'clared, that albeit the taking of fishes be allowed to all ' the lieges without prejudice of men's particular proper'ties, yet the exportation of fishes doth only belong to 'the merchants of the royal burghs, conform to the Act ' of this present parliament, which priviledges are hereby ' no ways infringed. And their Majesties, with consent 'foresaid, do recommend to the Lords of their Majesties ' Privy Council, to receive such overtures from the royal 'burrows or others, and to interpone their authority to ' such of these overtures as they shall find to be most ' convenient, and to conduce most for the better curing of ' fishes, and for the profit and honour of the trade.'

Another act was passed in the same reign, 1693, which 


\section{CHRONOLOGICAL HISTORY OF THE HERRING-FISHERY.}

orders that all herrings exported shall be packed in wellseasoned barrels of knaple, or oak; that each barrel shall contain eight gallons and two pints (Scots); that the staves and heading shall be of a certain quality and thickness, and "free of all white wood and worm holes;" that the barrels be properly branded and examined, and if found insufficient, condemned; and that the herring for export be made, pined, and cured with French, Bay, or Spanish salt, or with salt upon salt, made out of foreign salt; "and that all herrings for export (excepting such herrings as are exported to the Sound before the tenth day of September yearly) be repacked, well filled and washed;" and that proper inspectors be appointed to inspect all herrings exported, giving redress to the buyers in case of defects.

'ACT ANENT THE LOYAL CURING AND PACKING OF HERRINGS AND SALMON FISH.

' Our Sovereign Lord and Lady, the King and Queen ' Majesties, considering how much the true and loyal curing ' and packing of herring and salmon fish, to be exported ' forth of this kingdom, contribute to the advancement of 'trade and general good of the nation, do, therefore, with ' advice and consent of the estates of Parliament, statute, 'ordain, and enact, that all casks to be made hereafter ' for exporting herring or salmon fish be made of well' seasoned knaple or oak timber, free from all white wood ' or worm holes, the heads of the casks dowled, the step ' or stave of the third part of an inch at least in thick' ness, and that none of the staves be rift or clift, and 'that ilk barrel for exporting of herring contain eight ' gallons and two pints. And ilk barrel for exporting 
'salmon ten gallons, and be full hooped, at least, in the 'one end, and have eight hoops on the other end, ' and siklike; that these be kept in each royal burgh ' where casks for export are made, a burning seal for ' marking of such casks ; and that the magistrates or dean " of guild of the respective burghs appoint an honest ' cooper, for whom they will be answerable, for visiting ' and trying all barrels made for export; and that the ' maker of the casks put his own mark on them before he 'sell them, and call a cooper appointed by a royal 'burgh to try them, and if they be found sufficient, that ' he put the publick seal of the burgh upon them, for ' which the said cooper is to have four shillings Scots for 'ilk last from the maker of them; and that ilk barrel "which after such trial shall be found insufficient be con' fiscated and disposed upon for the use of the poor within ' the parish where they are made, excepting such parts "thereof as the respective magistrates shall think fit to ' give to the cooper visitor within the burgh for his en' couragement; and if the said casks shall be found in'sufficient after the publick mark of the burgh is affixed 'thereon, the cooper who visited the same is to pay ' therefore six pounds Scots for ilk last, and proportionally 'for ilk barrel; and whatever cask shall be put aboard 'before they be visited and marked, as said is, the same ' are to be seized and confiscated as insufficient, and ap' plied for the uses above mentioned, and suchlike; that ' all herring and salmon for export be made, pined, and ' cured with French Bay or Spanish salt, or with salt upon 'salt, made of foreign salt; and that all herrings for ex'port (excepting such herrings as are exported to the 'Sound before the tenth day of September yearly) be re'packed, well-filled and fished; and, in like manner, that 
' the magistrates in ilk royal burgh appoint an honest ' man of judgment and skill in curing and packing of 'herring, for whom they shall he answerable, to visit all 'herrings exported out of their precinct, who is to have 'a public burning mark, and to affix the name upon all 'casks which are found sufficiently cured and packed; ' and if any shall be found insufficiently cured and packed, 'after visiting and trying thercof, they are to be scized ' and confiscated for the uses aforesaid, and the first buyer ' is in that case to have recourse against the curer and ' marker of the said herring. But if the insufficiency 'thereof be discovered at the port of discharge, and be ' made appear, cither by legal probation from that place, ' taken from the dean of guild or merchant judge, or by the 'testation upon oath of the master of the ship who ex' ported the same, and two merchants of good fame de'claring the said insufficiency, and that the same hap' pened through the not riglit curing, marking, or packing ' of the herring at first, then the merchant exporter is to ' have recourse for the whole damage sustained by the ' insufficiency thereof against the first markcr or curer of ' the said herrings. And for rendering the said recourse ' effectual, all owners and markers shall put their own ' mark upon their casks by a burning iron; and whatever ' herring are exported without the marker's mark upon the ' cask, the merchant shall have no recourse for damages ' through the insufficiency thereof. And in case any cask ' with herrings be shipped for export without the said ' mark, the respective visitors who shall make discovery ' thereof are hereby authorised and empowered to seize ' and confiscate the same for the uses aforesaid, like as ' their Majesties, with consent aforesaid, ordain and ap'point the said visitors for the several burghs to be ad- 
'mitted to that trust, upon their taking an oath de fictele 'administratione, and finding sufficient caution for that " effect; and that for their pains therein they shall have ' six shillings Scots from the merchant or owner for ilk ' last to be marked by them in manner aforesaid. And fur-

'ther, it is appointerl, for preventing all clebate that may 'arise betwixt the visitor, merchants, and curers of her' rings and salmon that are sufficiently cured, upon "pretext that they are not sufficiently cured, in that ' case, upon any such difference in burghs royal, the 'magistrates are to call five honest men, well skilled in ' curing of herring and salmon, to decide any such differ' ence ; and in burghs of royalty and barony, or landward, 'the bailie of regality, or his deputies, and the baron, or ' his bailie respectively, is to chuse the like number of 'honest men for that end, and these five honest men are ' first to be sworn upon oath before they proceed to cog' nosce or decide in any such matter, and the visitors ' shall be obliged to affix their marks if these honest men ' shall declare them legally cured, and that under the 'penalty of ten pounds Scots toties quoties, and that there 'be an act of court, in presence of the respective magis'trates, made thereupon. But in regard of the great ' distance of some places on the northern and western ' coasts and isles, where herrings are in use to be cured ' and packed, from any burghs royal, wherethrough the 'visitors cannot mark the said herrings as well and ' loyally cured and packed, therefore it is statute and 'ordained, that the exporter of such herrings, who shall 'buy the same from those who cured them, shall be ' liable for the insufficiency of the cask,and the bad and "disloyal curing of the herrings, conform to this present 'Act, in the sum of forty pounds Scots money of penalty 
180 CHRONOLOGICAL HISTORY OF THE HERRING-FISHERY.

' for ilk last of the said exported herrings which shall be

' found unduly cured as said is, and that by legal probation, ' or by attestation and declaration in manner above men'tioned, to be applied to the behoof of the discoverer alle' narly. And for the betteradvancing of the trade of export' ing salmon fish, their Majesties and estates aforesaid, 'do authorise and empower the magistrates or dean ' of guild of ilk royal burgh to put this Act, and other - Acts of Parliament made thereanent, to all due execu'tion; declaring, nevertheless, as it is hereby expressly ' provided and declared, that neither this present Act nor ' anything therein contained, shall prejudice the particular ' rights of any burgh royal within this kingdom, but that ' the same be reserved to them as accords of the law: and 'siklike, declaring that this Act is and shall be but pre' judice to the power and privileges, rights and jurisdic'tions, of the Court of Admiralty.'*

It appears that the drawback of $£ 10,4$ s. Scots had not been regularly paid to the mercliants in the exportation of the herrings, for in 1698 another Act was passed, ordering the officers of customs to pay the drawback, and authorising the exporters to prosecute " the officers of customers" for the drawback, if not regularly paid; but it might have been more reasonable that the Treasury had paid it.

'ACT FOR THE ENCOURAGENENT OF WHITE FISHING AND HERRING FISHING.

'Our Sovereign Lord, considering that merchants and ' others who employ their stock upon the trade of fishing, ' have not received the encouragement granted them by * William and Mary, 1st Parl., 4 sec., 18th April 1693. 
' the 34th Act, 2 d session, of this Parliament, in getting' ' due payment of ten pounds four shillings Scots, from the

' customers of his MIajestie's customs, by way of drawback, ' for each last of herrings and white fish exported out of ' this kingdom: Therefore his Majesty, with advice and "consent of the estates of Parliament, does statute and ' ordain, that in all time coming the tacksmen or collec'tors of his Majestie's customs and foreign excise shall ' pay to the merchants, exporters of all herrings and white ' fish that they shall export out of this kingdom, or to ' take at sea, by busches, or other vessels, and export im'mediately, without being put on shore, the sum of ten ' pounds four shillings, for each last of herrings or white 'fish so exported; and that immediately, upon the ' merchant exporter thus producing' (at the custom-house ' where they reside) a bill of loading for the quantity they ' have exported, together with a certificate of the deposi'tions, duly taken before any inferior judge, of two of 'those that cured the said herrings or white fish, that ' they were all true and loyally cured with foreign great 'salt; and in case of the collector's refusal of payment ' upon production of the said bill of loading and certificate 'of depositions, then it shall be leisume to the merchant ' exporters to pursue them before any inferior judge for ' the said ten pounds four shillings per last, and that no ' advocation be given of any such process, or suspension of ' decreets thereon shall pass, except on payment, and a ' discharge produced. And his Majesty, with advice and ' consent foresaid, statutes and declares that all materials 'proper, and imported for the busch fishing, shall be free "of all custom and excise at their import, and that the ' said busch fishers exporting from sea, as said is, shall be ' allowed to prove the quautity exported, and the loyal 
' curing, after their return from abroad, before any judge 'competent, to the effect they may have the benefit of "the said allowance, as the same shall be found due."*

In the year 1702-3, the Dutch herring-fishery sustained a severe loss, in consequence of being attacked by six sail of French men-of-war; the Dutch fleet of fishing vessels was guarded by four ships of war, and the French having attacked them, sunk the admiral's ship, and the three others fled; the French then burned four hundred Dutch busses in Brussa Sound, and from this blow it is said the Dutch herring-fishery has never recovered. $\dagger$

The previous enactments having fallen into desuetude, in 170t, in the reign of Queen Anne, a very liberal enactment was made, showing that the proper knowledge of what was necessary was beginning to be acquired. This allows all the subjects of the kingdom to fish herrings, and gives free use of all the harbours and shores for landing, on payment of the ordinary rates; prohibits all other exactions, such as " a night's fishing" in the week, commonly called "Saturday's fishing;" top-money, stallage, and the like; enacts that all the herrings shall be cured with foreign salt; that the maker's name of the place shall be branded on all barrels of herrings exported, under penalties and seizure; that they should be liable to examination, and if defective, seized, and the curers or exporters fined; allows a bounty on exportation of $£ 10$, 4s. Scots per last of herrings fished by the busses, and $£ 24$ Scots per last of red herrings; and foreign fishers employed by the inhabitants or societies were to be cntitled to the privilege of British subjects while so employed; it exempted from

* Will. I., Parl, 7, c. 24, 19th July 1698, † Edmonstone, p. 268. 
duty, "cordage, hemp, pitch, tar, cork, plank board, knaples, skows, hoops, Dutch netts," and all other materials imported for the use of the fishers; and that herrings exported should be free of duty on exportation; it prohibits the curing of fish with Scotch salt, and the importation of English or Irish salt, and ratifies all privileges and immunities granted by former Acts. The following is the Act in question :-

\section{' ACT FOR ADVANCING AND ESTABLTSHING THE FISHING}

TRADE IN AND ABOUT THIS KINGDOM.

' Our Sovereign Lady and the estates of Parliament, ' taking into consideration the great and many advantages ' that may arise to this nation by encouraging the salmon, "white, and herring fishings, they being' not only a natu' ral and certain fund to advance the trade, and increase ' the wealth thereof, but also a true and ready way to ' breed seamen, and set many poor and idle people to "work, and albeit there be several good Acts already ' made to encourage and carry on that trade, yet they ' are either in desuetude, defective, or do not answer the 'present circumstances: Therefore, that so great and ' general a concerm may take effect in time coming, her 'Majesty, with advice and consent of the estates of Par' liament, authorises and empowers her goodsubjects of this ' kingdom to take, buy, and cure herring and white fish in ' all and sundry seas, channels, bays, and firths, lochs, 'rivers, \&c., of this her Majestie's ancient kingilom, and ' islands thereto belonging, wheresoever herring or white ' fish are or may be tilken, and, for their greater couveni' ency, to have the free use of all ports, harbours, shores, 'foreland, and others, for bringing in, packing, drying, un- 
' loading, and loading the same, upon payment of the ordi" nary dues, where harbours are built, that is, such as are ' paid for ships, boats, and other goods, and discharges all 'other exactions, as a night's fishing in the week, com'monly called Saturday's fishing, top-money, stallage, and 'the like; and for the better advancing and carrying on ' the same trade, her Majesty, with cousent aforesaid, or'dains and enacts, that all the barrels made use of by ' the said fishers shall be of the largeness, goodness, and 'quality, and marked as is prescribed by the fifth Act of ' the fourth session of the first Parliament of William and " Mary, and that all the herring and white fish put into ' them shall be pined, cured, and packed, from the bottom "to the top with foreign salt allenarly; and further it is "ordained, in manner foresaid, that no salmon, herring, ' or white fish, be shipped or transferred from this king'dom to foreign countries but such as are made by the ' subjects of this kingdom, and marked by the seal of the ' marker and merchant, exporter thereof, to the effect it ' may be known who has made the same; and the collec' tors and other officers of the customs are hereby com' manded to take and seize all salmon, herring, or white ' fish, that shall be shipped in their several precincts of ' exportation, unless made and marked, as aforesaid; and, 'to prevent the counterfeiting of the foresaid marks, ' her Majesty, with consent foresaid, does allow any 'company, society, or single person, to use and appro' priate to themselves any particular mark to be used by "them upon salmon, herring, or white fish, by and attour ' the commun mark and burn of the port from whence they ' are exported, and to registrate their taking and using 'such a mark in the Publick Register in Edinburgh; and ' her Majesty, with advice and consent of the said estates, 
'strictly prohibits and discharges all other companies, 'societies, or persons, to assume or use the mark of any ' company, society, or person so registrate, certifying such ' as do in the contrary they shall be liable to the com"pany, society, or person, to whom the mark belongeth, ' in the sum of five hundred merlss totics quoties. And ' it is hereby declared, that it shall be lawful to the 'sheriffs, bailies of regalities, and magistrates of burghs, 'or any having commission from them, not only to visit, 'on all occasions, the curing and packing of herrings or ' white fish in their respective bounds, and also to pitch ' upou any barrel after it is made up and marked up, and ' cause break open the same, and raise the herrings, if 'they think fit, from the very bottom, and in case they 'be not cured or packed as above ordained, or that they 'be broken, bruised, spilt, or not gutted herring or fish 'among them, the said sheriffs, bailies, magistrates, or 'others commissioned by them, after the same is clearly 'proven by experienced and famous witnesses, are hereby " ordained to secure the whole casks where the said insuffi' cient herring or white fish shall be found; the persons to ' whom they belong shall pay for each last one hundred ' merks Scots, the half to be given to the discoverer, and ' the rest to the poor of the parish, and proportion' ally for smaller quantities of such insufficient herrings 'or white fish, and the said insufficient herring' or fish 'shall be discharged to be exported at any time there' after. And her Majesty, out of her royal bounty, hath ' allowed, and liereby allows, to the exporter of each ' last of white fish and herring taken any manner of way, ' and exported out of this kingdom, a reward of ten " pounds four shilling's Scots money, in the term of the ' former Acts of Parliament-and for each last of herrings 


\section{CHRONOLOGICAL HISTORY OF THE HERRING-FISHERY.}

' taken in bushes, and exported out of this kingdom, a ' reward of eighteen pounds - and for each last of red her' rings exported as said is, a reward of twenty-four pounds, ' - either to be paid to the exporter, his heirs, executors,

'or assigns, by the next collector of her Majesty's cus'toms to the port from which the said herring or white ' fish are exported, or, in the opinion of the merchant ' exporter, that he have retention of the foresaid allow' ance or drawback in the first end of the custom, and ' excise of the first foreign goods imported by him, either ' in the ship that exported the herring or white fish, or ' in any other ship, the export being instructed in the 'terms of the 24th Act of the Parliament 1698, certifying ' all contraveners that they shail be liable to the penal' ties contained in that Act, attour to loss of their offices, ' and that their being incapable to be employed in any 'office about the customs thereafter; and further it is ' statute and ordained, that the exccution provided by " this Act for recovery of the drawback of herring, shall ' be extended to the proprietors and exporters of salmon, 'cured in manner above mentioned, for the drawback 'appointed to he given on that account by the former ' Act thereanent. Moreover, her Majesty, for further ' encouragement to any who shall undertake the im'provement of the herring and white fishing, hereby, "with advice and consent foresaid, statutes and declares "that all foreigners, or strangers, fishers, who shall be ' employed by any of the foresaid particular persons or 'societies, and reside in this nation, shall enjoy all the " privileges of free-born subjects during the said resi'dence; and also statutes and ordains, that cordage, 'hemp, cork, pitch, tar, plank board, kuaples, skows, 'hoops Dutch netts, and all other materials to be im- 
' ported for the trade of fishing, shall be free of custom, or ' any other imposition whatsoever; and that the herring 'or white fish, taken, cured, and packed as foresaid, are ' and shall be free of any manner of duty or taxation to ' her Majesty in the exportation of the same. And fur'ther, her Majesty, with consent, ratifies and approves ' all former Laws and Acts of Parliament, made anent 'the slaying and destroying of red fish, smolts, and sal'mon, and hereby requires and commands the judges 'therein mentioned to put these laws to due execution, ' and to that effect to hold courts twice a year, Pasch and ' Michaelmass yearly, at the ordinary place of such court ' rvithin the jurisdiction, and to punish the delinquents per'sonally if insolvent; certifying such judges as shall fail ' to hold courts, and uplift the fines, or punish delinquents ' as said is, after these being required thereto personally ' under form of instrument by any house, or other per' sons concerned, they shall be liable in the sum of five ' hundred merks, toties quoties, to belong to the person 'who shall pursue the judge, so failing or refusing to do ' justice in manner above expressed. Aud it is hereby 'declared, that such processes as shall be commenced 'before the Lords of Session for that effect shall be dis' cussed summarily, abiding the courso of roll, impower' ing the said lords to modify the expense of plea by ' and attour the penalty. And siklike the officers of the ' independant company, and otlier officers of lier MIajesty's 'customs, are hereby required to apprehend the per'sons of delinquents, that may be either found guilty or ' declared fugitive, and that upon tlıe warrant or orders ' of the judges ordinary, for their serving' as recruits, con'form to the 33d Act of the 6th Session of King Wil'liam's Parliament; and also strictly prohibits and dis- 
' charges all fishing of salmon from Saturday at twelve of ' the clock at night, till Sunday at twelve of the clock at ' night; and because all manner of sorting fish for export " with Scots salt is hereby discharged, therefore her 'Majesty, with advice and consent foresaid, strictly pro' hibits and discharges the importation of all English or ' Irish salt from and after the first day of October next to ' come, under the penalty of one thousand merks Scots ' money, to be exacted from and paid by the seller, im' porter, and buyer, toties quoties, confiscation of the ship, 'bark, and boat wherein it is imported, and in case of the ' importing the same by horses, confiscation both of the ' horse and salt, and the carrier to be fined in twenty 'pounds Scots, and punished in his person by twenty 'days' imprisonment, and any person having commission 'from the salt master, or any of them, is empowered to 'seize the said salt, ships, barks, boats, or horses, and to 'pursue the contravener hereof, before any magistrate or 'justice of peace whatsoever, who are hereby empowered ' and required to put the same to due execution, declaring. ' that the one-half of the said fines and seizures shall 'belong to the apprehenders and pursuers, and the 'other half to the poor of the parish where the trans'gression is committed. Lastly, her Majesty, with ad'vice and consent aforesaid, ratifies and approves all 'benefits, priviledges, and immunities already granted ' by any Acts of Parliament in favour of the white her' ring, and salmon fishings, and all persons concerned 'therein.'*

The union of the two kingdoms in 1707 lad a very injurious effect on the herring fishery, on account of the high duties on salt then introduced, the unsettled state of * Queen Anne, 1st Parliament, 3d Session, 6th July 1704. 
the country, and the want of legislative protection and encouragement. The fishery seems to have, however, recovered some years afterwards, for we learn that, in 1710 Anstruther sent thirty boats to the fishery at Lewis Island, and Crail had eighty boats, which went to the coast fishing at the mouth of the Forth, and about two hundred boats came to this fishing from other parts. In 1720 an association was formed in Scotland for the purpose of encouraging the fishery, and for carrying it on in busses. This association consisted of upwards of two thousand of the principal inhabitants of Scotland, and a considerable sum was subscribed in $£ 100$ shares; but a great part of the funds was expended in building large vessels in imitation of the Dutch busses; and the people employed being quite unaccustomed to, and ignorant of, this mode of fishing, the attempt was, of course, unsuccessful, and in a short time relinquished.*

In 1727 an Act (1 Geo. I. cap. 26, 30) was passed for the encouragement of the manufactures and fisheries in Scotland ; and his Majesty, under this Act, by patent dated 12th July 1727, created "the Board of Trustees for MLanufactures and Fisheries," consisting of twenty-one noblemen and gentlemen of rank in Scotland, for the purpose of promoting these national objects. They were empowered to appoint "proper and qualified persons to be wrack (a 'German word implying selecters) and cure-masters of 'the herring-fishery, and riding officers to oversee and 'superintend the same.' And the Board was also empowered to offer small premiums to be paid out to the several fishermen, who, upon different parts of the coasts, made the first discovery of herrings for the coast

* Copartnery for carrying on the Fishing Trade ; Edinburgh, 1720. Letter on the Fishing Company; Edinburgh, 1723. 
190 CHIONOLOGICAL HISTORY OF THE HERRING- FISHERY.

fishing in each season, not exceeding $£ 100$ per annum; and the following sums were allotted:-

L.2 sterling per last for so many vessels fitted out as bush fishing vessels, . $\quad \begin{array}{llll}\text { L.1839 } & 0 & 0\end{array}$

L.2 per ton for 4 vessels above 20 and not exceeding 50 tons, for fishing 3 months, and L.1 per ton for fishing 3 months longer, . $\quad 360 \quad 0 \quad 0$

For 5 boats, from 12 to 20 tons, to fish on the east coast and the mouths of the Moray and Forth Firths,

$\begin{array}{lll}150 & 0 & 0\end{array}$

For premiums to fishermen who shall discover shoals on the east of the Forth, $\begin{array}{lll}36 & 0 & 0\end{array}$

Salaries to 10 wrack and cure-masters, at L.10 each, . .

Salaries to 3 riding officers, L.55 per annum each,

$\begin{array}{lll}360 & 0 & 0\end{array}$

$\begin{array}{lll}100 & 0 & 0\end{array}$

$\begin{array}{lll}165 & 0 & 0\end{array}$

L. $2650 \quad 0 \quad 0$

The herring-fishery, however, seems to have been rather neglected for several years, notwithstanding the numerous efforts of the Board and of private individuals; and one gentleman having, in 1734, written to the celebrated Dean Swift on the subject of the fisheries, elicited a most characteristic reply, of which I have fortunately a copy, and which is as follows:-

“ Dubuin, 23rd Ararch 1784.

"Sir,-I return you my hearty thanks for your letter and discourse upon the fishery; you discover in both a true love of your country, and (except your civilities to 
me) a very good judgment, good wishes to the United Kingtom, and a perfect knowledge of the subject you treat; but as you are more temperate thian I, and, consequently, much wiser (for corruptions are apt to make me impotent to give offence, which you prudently avoid), ever since I began to think I was enraged at the folly of England in suffering the Dutch to have almost the whole advantage of our fishery just under our noses. I love them for the love they have to their country, which, however, is no virtue in them, because it is their private interest, which is directly contrary to England. In the Queen's time I did often press the Lord Treasurer Oxford, and others of the ministry, upon the very subject. I laughed to sce the zeal that ministry had about the fishing of Newfoundland, I think, while no care was taken against the Dutch. As to my native country (as you call it), I happened, indeed, by a perfect accident, to be born here, my mother being left here from returning to her house at Leicester, and I was a year old before I was sent to England-thus I am a Teague, and an Irishman, or what people please, although the best part of my life was in England. What I did for this country was from perfect hatred of tyranny and oppression, for which I had a proclamation against me of L.300, which my old friend, my Lord Carteret, was forced to consent to, the very first or second night of his arrival hither. The crime was that of writing against the project of one Wood, an ironmonger, to coin L.108,000 in half pence, not worth the fourth part of the money, which was laid before the people in so plain a manner that they all refused it, and so the nation was preserved from immediate ruin. I have done some small service to this kingdom, but I can do no more. I have too many years upon me and too much sick- 
ness. I am out of favour at court, where I was well received during two summers six and seven years ago. The governing people do not love me, for, as corrupt as England is, it is a habitation of saints in comparison of Ireland. We are all slaves, and knaves, and fools, and all, but bishops and people in employments, beggars. The cash of Treland does not amount to L.200,000. The ferw honest men amongst us are dead-hearted, poor, and out of favour and power. I talked to two or three gentlemen of this IIouse of Commons, now sitting here, mentioned your scheme, showed liow very advantageous it would be to Ireland; they agreed with me, but said that if such a thing was proposed, the members would all go out, as a thing they had no concern in. I believe the people of Lapland, or the Ilttentots, are not so miscrable a people as wo, for oppression supported by power will infallibly introduce slavish principles. I am afraid that even in England your proposal will come to nothing; there is not virtue cnough left among mankind. If your scheme should pass into a law, it will become a job; your sanguine temper will cool, rogues will be the gainers, party and faction will intermingle and defeat the most essential part of the whole design; standing armies in the time of peace, projects of Excise, and bribing elections, are all you are like to be employed in,-not forgetting septennial parliaments, directly against the old Whig principles, which always have been mine. A gentleman of this kingdom, about three years ago, joined with some others in a fishery here in the northern parts; they advanced only L.200 by way of trial; they got men from Orkney to cure the fish, who understood it well; but the vulgar folks of Ireland are so lazy and so knavish, that it turned to no account, nor would anybody join with them, and so the 
matter fell, and they lost two-thirds of their money. Oppressed beggars are always knaves, and I believe thero are hardly any other among us; they had rather gain a shilling by knavery than five pounds by honest dealing. They lost L.500 a-year for ever in the time of the plague at Marseilles, when the Spaniards would have bought all their linen from Ireland, but the merchants and the weavers sent over such abominable linen that it was all returned back, and sold for a fourtlı part of its value. This is our condition, which you may please to pity, but never can mend. I wish you good success with all my heart. I have always loved good projects, but have always found them to miscarry.-I am, Sir, with true esteem for your good intentions," \&c.

About this time, as connected with the herring-fishery, there occurred a circumstance worth recording of two eminent Scotsmen of their day; in the year 1738, tho colcbrated Lord President Duncan Forbes, of Culloden, having accompanied the great John Duke of Argyle, to Tyree, in the month of June, he, to prove to his Grace what great riches his coasts possessed, privately persuaded, against their will, but by means of a bribe, one of the fishermen to cast his nets one night for herrings, and to the wonder of the fishermen they got 2000 fine fat herrings. Next morning early, the Lord President, being informed of the result, he, unknown to the Duke, got some of the herrings in the manner of tho. district "nicked" and boiled in salt-water, and another dish of herrings splitted and dressed with pepper and salt, and broiled on the gridiron; and both these dishes were offured by the Lord President to his Grace at breakfast. "Duncan," says the Duke, "I havo often caten herrings at dimner, 


\section{CHRONOLOGICAL HISTORY OF THE HERRING-FISHERY.}

and sometimes at supper, but never at breakfast; but since you have taken so much trouble to procure them, I must try the Tyree herrings." His Grace was so much pleased with their nice flavour, that he ate two of the boiled ones; upon this Forbes produced the other dish, saying, "I hope your Grace will taste the broiled ones," who answered, "Duncan, you are a most extraordinary man, there is no resisting your entreaties." And having partaken of them also, he declared they were " the most delicious fish he had ever tasted," praised the Lord President for his public spirit and ingenuity, in having allured the fishermen to a sense of their interest, it being evident that before this they had been ignorant of the herrings being on the coast so early; and it is said that the Duke resolved to cause the fisheries to be pushed forward with vigour; but other affairs seem to have prevented him, and for many years the fishery on that coast was neglected.*

In the year 1749, King George II., at the opening of the Session of the British Parliament at the close of the year, pointed out in his address the advantages of encouraging the herring-fishery, upon which a committee was appointed by the House of Commons to examine and report as to the best means of improving the white herring, and other fisheries. This committee was appointed, after a resolution of the House of Commons had been passed, in the following terms: "That the carrying on, and improvement, of the British white herring and cod fisheries are of great importance to these Kingdoms, as they may be of evident advantage to the trade and navigation thereof, and may be a means of employing and providing for great numbers of industrious poor; provided the said fisheries be carried on by a large joint stock com-

* Loch on the Trade and Fisheries of Scotland, vol. ii. p. 167. 
pany, under proper regulations, and reasonable encouragement be given thereto ;" and this truly wise and patriotic suggestion was warmly taken up by all classes. For centuries the rich treasures of the deep on the Scottish coasts were neglected, from the want of that guiding and directing superintendence which has since so admirably brought the treasures forth. Consequent on this royal message, and the appointment of the committee of the House of Commons, numerous books and pamphlets were written, suggesting various plans, some of which it may be worth while here to glance at. The first we shall notice is, "Plans and Proposals by a Gentleman conversant in the Fishery, Presented by E. Vernon, Esq., 1750." This gentleman states, that in 1738 he joined with others, and sent " three vessels and two 'jaggers' to fish with the Dutch, and experienced that they could cure the fish as well as the Dutch, and the 'jaggers' got first to market at Hamburgh and Bremen, and that the herrings sold at as good a price as the Dutch, but that the success was destroyed by the salt regulations ; for," he says, "he could not have cleared without the Chancellor of the Exchequer's (then Sir Robert Walpole) recommendation to the Salt Commissioners, to accept of such account as he could give, and he, soon going out of power, and they despairing of having the same altered, as they depended on his friendship, they proceeded no further in it." He objects, in his paper, to the compelling the landing of the fish from the busses, and suggests rules as to the salt and bounty on the ships and herrings. He recommends the people to eat them, and says, "The Dutch have much the advantage in their sanction for their selling them, besides their natural relish of them, sparing no cost for the purchasing the first fish, and he is esteemed very unpolite who does not 
eat of them. I wish we had as good a liking to them in these kingdoms." He also speaks from experience when he says, "I am very strongly persuaded the keeping the Dutch and French in proper limits at sea would be a great point towards the establishing our own fishery, and without which, I very much fear, we shall never be able to make any great progress, as they will be everlastingly teazing and plaguing our fishermen. I must think that 110 one can dispute our right, so far as our Admiralty jurisiliction extends." He points out some of the causes of the superiority of the Dutch herrings, and otherwise scems to have understood the subject. Another is"Scheme for Promoting the British Fisheries," by George Walker, who recommends the formation of a company called the Free British Fishers' Society, without excluding private companies or parties from fishing on equal terms. We are here informed that at that period (1750) "there were 1100 British sailors in the Dutch fisheries; and to avoid giving our allies, the Dutch, umbrage, application should be made to his Majesty to call home all British sailors in general" (page 20). Ile also wisely remarks, "As all men are, by nature, alike, so we would all beg, steal, and be idle, if our nature were not improved by education;" and he says, "it would be wise to employ the parochial pauper boys as apprentices in such a fishery, on certain conditions," and points out the propriety of modifying the regulations as to salt, the high duties on which caused much annoyance. The next pamphlet we shall notice is entitled, "To the Committee upon the British Fishery, King's Arms Tavern. By ML. N." This author says, "The promotion of the herring and cod fishery upon our coasts will increase our naval force, civilise the Highlands, employ the poor over the whole 
kingdom, and promote trade in general, as well as augment the revenue;" and he recommends the payment of tonnage bounty under certain regulations. We liave next some very useful remarks in "Proposals for the White, Herring, and Cod Fishery, lumbly submitted by Mr Grant." He points out the profit to the nation by the building of busses, and suggests that the equivalent money appropriated by the Act 1727, amounting to L.4000, shall be applied to improve "the boat fishing:" Arotlier is, "Reasons Supporting the Proposals for carrying on the British Herring-Fishery, \&c.," by E. Vernon, Esq. This writer says, "That the Dutch herring-fishery, besides vessels and tenders, formerly employed 3000 busses and 40,000 seamen, and that the United Provinces thereby gained, according to the Pensioner De Witts' calculation, five millions sterling per annum, and he said it was the navy of Holland that crabled it to dispute with Spain." He also says, "The foreigners broke the attempts of the Scots some years ago, and also that which Sir John Eyles and others wore concerned in, by underselling for a time at all markets they can carry them to, and that, therefore, a joint stock company is necessary successfully to stand such competition." The next is "A Proposal on the Fishery. By Friendly." He recommends "the formation of a jointstock company," to be encouraged by Parliamentary authority, and bounties on the fishing vessels, and remarks, that "from such a glorious undertaking the nation instantly will receive blessings, for it will certainly bring into these kingdoms large sums yearly from foreign nations, or elso in merchandise, and increase the public revenue."

The author of the address "To the Committee upon 
the British Fishery at the King's Arms Tavern," says, "It is with great pleasure I observed the motion in the House of Commons to promote the fishery on the coast of Scotland;" and also, "it is very desirable that every discouragement should be removed in the first place;" and says "that the fishery was formerly a royalty, and every fishing-boat was taxed according to the number of men it employed and of the nets used, and the tax was for every net L.10 Scots money, or 16s. Sd. sterling; and on the accession of James VI. to the crown of England, he granted the tax to certain of his nobles, whose descendants levy it to this day ;" and advises its abolition. He recommends the employment of the seamen of the ships of war discharged in consequence of the peace, and says "that to carry on this beneficial trade, at least 400 vessels from 50 to 100 tons will be necessary, each vessel to be navigated by ten men ;" and suggests a bounty of $3 \mathrm{~s}$. per barrel on each barrel exported, and that the produce of the fishery be divided thus. "That (the provisions being defrayed out of the fish taken) the residue be divided-one-third for the use of the vessel, nets, \&c., and two-thirds to the hands employed therein, then the fishermen's proportion to be twenty-four shares, to be divided among them in certain rates;" but he does not suggest how the money for the undertaking is to be obtained.

The author of "A Proposal for Encouraging and Promoting the Fisheries of Great Britain, and for the Raising and Increasing of Mariners for the Service of the Royal Navy. By N. W.", says "that the fisheries have always been esteemed one of the best nurseries for the training and bringing up of hardy and industrious seamen and that 10,000 such men, with the usual complement of mariners and landsmen, will always be sufficient 
to man (of different rates) near a hundred sail of his Majesty's ships of war ;" and suggests a registry to be kept of volunteers, to be paid certain rates; and recommends the abolition of impressment.

The next to be noticed is the address "To the Committee appointed to receive Proposals and prepare a Plan to be laid before Parliament for Extending and Improving the Fishery; by A. B. C., Sword Blade Coffeehouse," who properly enough considers "that all fishers and curers ought to be henceforth exempted from the grievous tax of excise or teind, as well as from all vassalage dues and service whatever;" he recommends a bounty of $30 \mathrm{~s}$. per ton on all vessels fitted out for the fishery; and the formation of a joint-stock company, which should be guaranteed and paid by the nation L.3 per cent. on all money expended; and the building of towns and settlements on the coasts."

Another is "A Scheme for Retrieving and Supporting a Decayed Branch or Two of the British Fisheries," by Joseph Cockburn. He proposed "that all strangers fishing be kept off our coasts, not suffering any to come nearer than in former times, or they should be obliged to take licences from us for fishing in our district, or be liable to seizure;" and the granting of a bounty to encourage our own fisheries; and the building of shallops of forty-five tons each, which, with nets and provisions, he reckons will cost each L.750.

We have "Some Observations on the Present State of the British Fisheries, and Means of Improving them." This work describes the mode of fishing and curing then practised by the Dutch, and says, "We rvant only encouragement to carry this trade entirely from the Dutch, and one of the greatest would be to make early herrings fashion- 
able; indeed, all lovers of their country ought to have them at their tables in the month of July, if possible. He recommends that strange ships should be kept off the coasts, as he says "THEIR LARGE SHIPS PREVENT OUR SUIALLER ONES AND BOATS, AND DESTROY OUR NETS;" that foreign salt should be allowed free of duty for the fisheries; and that a bounty should be paid on all cured fish; and the building of stores and warehouses on the coasts where the herrings are obtained. He urges the encouraging the Highlanders to fish, and says of them, "As to this people's genius for manufactures, observe their tartan and plaid, the whole of which, from first to last, is performed ly one family; and for their mechanical genius, I appeal to the curious arms they make." He advises the formamation of a joint-stock company to advance money to purchase lands and build towns in the north, and to build and furnish boats, and also to procure nets for the people. He says, the people on the cast coast take shares in boats, and " the shares are, to a man half a share, to the net half a share, and to the boat one whole share; so that if you fit out the boat with eight nets, which may cost in all about L. 28 or L.30, you will have the five-ninths of the produce of eight men's labour for the season, and the other fourninths you may purchase at a very low price." He concludes by saying, "It only remains, therefore, that this glorious design be pursued with constancy, spirit, and prudence."

The author of "Considerations upon the White Horring, and Cod Fisheries," endeavours to prove that the plan of a joint-stock company, supported liy premiums, bounties, and guaranteed interest from the nation, is free from all objections, and that such a measure is necessary to give cmployment and profit to the people who were 
then out of employment; and that the encouraging the commencement and improvement of the herring and cod fisheries would add great wealth to the nation, and be an admirable nursery for seamen. It appears that there had been no fisheries of importance in 1749 when he wrote, for he says, "It is very plain that our not succeeding hitherto in any degree proportionable to what might be expected from the possession of such advantages, has been owing either to want of care, to want of diligence, to the want of due regulations, to the want of a sufficient capital, or joint stock, and finally, то THE WANT OF A PROPER AUTHORITY TO GUIDE, INSTRUCT, AND INSPECT THE CONDUCT of such fisheries. These, and these alone, are, and must be, the cause of former miscarriages."

This author gives us important information as to the obstacles the Dutch had to contend with, and of the means they took to defend themselves, and which furnish curious statistics as to the value of the herring-fishery between the end of the sixteenth and beginning of the seventeenth century. He says:-

"Towards the end of the preceding and begimning of the last century the Dutch herring-fishery was so distressed by the Dunkirkers, then subjects of the crown of Spain, that a tax was imposed of a florin per last, in order to fit out and maintain a squadron sufficient to protect the herring busses, and to block up the port of Dunkirk. This tax produced annually 300,000 florins;" and as the herrings then sold from L.10 to L.20 sterling per last, but generally about L.12, the amount of their herring-fishery might be well computed at three millions and a half of our money. It was at that time looked upon as certain that the French, Emdeners, Bremencrs, and Hamburgers, took altogether about the same quantity of fish with the 
Dutch, so that our seas produced to foreigners, one year with another, between six and seven millions sterling."

This publication evinces great talent and a masterly command of language and argument; the following, for instance, is a very just remark :-

"It is impossible to devise a more natural or more efficient defence for an island than to have the coasts covered and guarded by towns well inhabited, and that, too, by persons of considerable property, and, consequently, equally capable and inclined to exert their utmost force for their own preservation against foreign invaders. We may add to these, other apparent and sensible advantages, such as the breeding of a numerous race of hardy, active, and able seamen and fishermen in all these ports, who, by their labour in time of peace, will be able to maintain and support themselves and their families, and be always at hand to man the Royal Navy in time of war, without difficulty or trouble. We conclude by saying, that this noble undertaking, so long wished for, and at this juncture so much wanted, may be at length gloriously accomplished, for the universal advantage of the British people ought to be the sincere endeavour and the indefatigable study, as well as the zealous and ardent prayer, of every good citizen, who has a due concern for the interest, safety, and welfare of his native country."

Out of the great number of able pamphlets and books written in favour of promoting or beginning the herringfishery, the last we shall notice is "A Letter to a member of Parliament, 1750." The motto on the title page is an appropriate one, from " Thomson's Seasons," namely,-

"With adventurous oar

How to dash wide the billow; nor look on, Shamefully passive, while Batavia's fleet 
Defrauds us of the glittering finny swarms,

That heave our firths, and crowd upon our shores;

How all enlivening trade to rouse, and wing The prosperous sail, from every growing port, Unchallenged, round the sea-encircled globe;

And thus, in soul united as in name,

Bid Britain reign the mistress of the deep."

He quotes a letter from "Loch Rogun," stating that, in June 1749, that loch, a bay of the sea, was full of herrings, and that the people had not salt, casks, or materials remaining. He hints at the probability of getting herrings in the Murray Firth, seeing that the salmon caught there in August had often herrings in their stomachs; and from his remarking that five or six hundred barrels were cured off Austruther in August 1749, we learn that the periodical visits of herrings in both firths were unknown, and had been subsequently discovered from the encouragement given by the Trustees or Fishery Board of subsequent years. He states that there "was great plenty of herrings last year" (1749) at Ayr; " they filled all the barrels and casks they could get, cured all their salt, and still the herrings continued." He states, also, that in 1749 the French had several herring busses in the North Sea, and that there were also several Swedish busses similarly employed. And he speaks of the various attempts made by the British nation to promote the fisheries, "but for what reason none have been effectual I am at a loss," he says, "to determine."

He informs us that the merchants of London petitioned the House of Commons, in 1749, for a fishery, which petition, he says, mentions " the benefit that would accrue to the United Kingdom from the establishment of a fisheryviz., the increasing the vent of our staple manufactures; the multiplying of our seamen; the employment of a vast 
number of industrious and otherways helpless poor; the lessening the parochial and public taxes; and improving the national wealth."

He then points out various localities for erecting villages and stores for the fisheries on the Scottish coasts, and gives a statement of the Custom-house duties on the various materials required in building busses or fishing-vessels, by which it appears that these duties, in the building and fitting out one such vessel, amounted at that time to upwards of L.150,-thus proving the wisdom of our forefathers in granting bounties or premiums on such vessels, to enable them to compete with vessels built ahroad free of duty; and he recommends that the nation should pay four per cent. on the capital of a joint stock company, as payment or return for the customs duties on raw materials used, but that no premium be paid if the profits exceed three per cent.; but he suggests that, to prevent a monopoly by such company, private adventurers under certain regulations should be placed on a similar footing, and, to effect this, that the bounty should be 40 s. per ton on the busses fitted out.

He concludes by saying, "Upon the whole, you may see how necessary it is to apply proper remedies, which we are the more sanguine to hope, as his Majesty, in his most gracious specch at the opening of this session of Parliament, so strongly recommended the maintaining of our navy, and improvement of trade in all its branches."

All those favourable to the undertaking were truly without experience, and the difficulties great, in consequence of the crroneous laws and exactions; but a society soon subscribed a capital of L.500,000, and an Act of Parliament was passed in the same year (Act 23, Geo. II. Cap. 24, 1750), incorporating a cumpany for twenty- 
one years, and embodying regulations for the management of the fishery. It enacted that three per cent. per annum should be paid out of the customs to the company for every L.100 actually expended, for fourteen years, and a bounty of 30 s. per ton on all decked vessels built or fitted out for the fishery of from twenty to eighty tons, said vessels to be on the east coast at the rendezvous of Brassa Sound, in Shetland, on or before the 11th June each year, but not to shoot their nets before the 13th June, and continue fishing till the 1st October; the vessels on the West Coast to rendezvous at Campbelton on or before the 1st September each year, and continue fishing to the 31st December, unless the loadings were sooner completed. Each vessel was to have a journal of proccedings, of the quantity of fish sent to foreign markets, of the quantity brought into port, to carry twelve Winchester bushels of salt for each last of herrings the vessel stowed, the herrings to be barrelled in new barrels; each vessel of seventy tons and upwards to have two fleets of tanned nets-namely, one fleet of fifty nets, each net to be thirty yards full upon the rope and seven fathoms deep, and in proportion for a vessel of greater or lesser tonuage on board, and be provided with one other fleet of fifty like nets on board a jagger or tender sent to attend the said fishery, or left on shore in a proper place for the use of such buss or vessel; each vessel of twenty tons to have six men, and larger vessels to have one man for every additional five tons. This Act did not exclude others from fishing as before; other companies, subscribing L.10,000, or more, were also permitted to carry on the fishing separately with the same advantages, but were not to have any share of the profits in the society. 
Agreeably to this Act, his Majesty's Charter of Incorporation was granted, 11th October $1750 *$

Great expectations were raised as to the result of the undertaking; fishermen were brought from Holland by the society in 1750 , and the curers learned the art of preparing the herrings in the best manner; and the herrings thus cured, when sent to the continental markets, were found to be of similar quality to the Dutch. But this enterprise seems not to have succeeded, and the want of success may be attributed to the want of practical experience in the directors, the distance of head-quarters from the fishery, and to the death of the Prince of Wales in 1751, who had zealously patronised and promoted this great national undertaking. It appears, besides, that although the L.500,000 had been subscribed, only a small part of the capital had been paid up. $f$

From the only facilities afforded by the vagueness of the Act, frauds had been attempted by some parties endeavouring to get more bounty than was legally allowed; for in 1753 it was enacted, that vessels returning from the fishery with fewer hands than the law of 1750 required, should not be entitled to the bounty, unless death, sickness, or desertion, was satisfactorily proved, and that the quantity of herrings sent to foreign markets should be proved by the oath of the society's superintendent.

In 1752, Dr James Silvis Dodd, President of the Robin Hood Society, published an essay on the herring, pointing out the propricty and advantage of prosecuting the fishery, and dedicating the brochure "to Slingsly Bethel, President; and Stephen Janssen, Vice-President;

* Act 23, Geo. II. cap. 24.-Anderson's History of Commerce, vol. ii. p. 391.

† Fraser's Domestic Fisheries, p. 79. 
and the Council of the Free British White Herring Fishery." He describes the herring as highly nutritious and medicinal, and "good for food in the plagues." He gives several recipes for cataplasms of herrings as being in use at the time; and he recommends the oil of herrings as "of excellent service in cramps and convulsions." He recommends the elixir "ossium halecum" as "excellent in febrific cases." His recipe for making this elixir of herring bones is a curiosity, and as such worth quoting; he says, "Take $10 \mathrm{lbs}$. of herring bones, dryed and grossly powdered, put them in a retort, lute it, and place it in an open furnace; give it a degree of fire every two hours till no fumes are seen in the receiver. Then let all cool, and there will be an oil, a volatile salt, and a pungent volatile spirit, which put in a clean retort, and by fire unite together. Then take 8 ounces of this united spirit and put into cucurbit with 2 pounds of rectified spirits of nitre, $1 \mathrm{lb}$. of diaphoretic antimony, and 4 ounces of volatile salt of tartar; distil and cohobate so often till it is perfectly united; then add an ounce of oil of nutmeg, and half an ounce of oil of cinnamon, digest in a matrass ten days, and pour off for use, which keep in a well stopt bottle; the dose of this is from 4 to 10 drops whenever a high volatile cordial is necessary.,**

The fishery was still found to be less successful than expected; and the Act 26, Geo. II. cap. 9, 1753, therefore, permitted the busses toreturn to port, during the fishing, to refit and prepare for the Yarmouth fishery. The depth of the nets for this fishery were not to be under five fathoms, and the busses for the east coast of Scotland were permitted to rendezvous at Kirkwall on or before

* Dodd on the Herring, p. 105. 


\section{CHRONOLOGICAL HISTORY OF THE HERRING-FISHERY.}

the 12th September, and continue fishing to the 1st January, unless the loading was sooner completed; and they were not obliged to carry to the fishing more than one fleet of nets.*

In 1755 an Act was passed continuing the payment of three per cent. interest on the capital subscribed by the society, and the tonnage bounty for three years longer than allowed in the Act of 1750 , and permitting the society to hire out their busses to others, and giving more freedom as to places of rendezvous, and permitting the fishery to be carried on in any part of the British seas. $\dagger$

Another Act was passed in 1756, the preamble of which states, "That the extension of the British fishery is of great importance to this kingdom, as it not only adds considerably to the national wealth, but is moreover a fruitful nursery of able seamen for the public service." It gives more liberty to our fishermen as to fishing on the coasts of Scotland, and in using harbours, and occupying uncultivated grounds for landing nets and material; and permits any one, from and after the 25 th June 1756 , "to take or buy from fishermen, and cure any herrings or other fish $; " \ddagger$ and it enacts that the barrels shall not be

* Anderson's History of Commerce, vol. ii., p. 401.

† Ibid., vol. ii. p. 408.

† This Act is of extreme importance, both to fishermen and curers; for clause first gives free permission to British subjects to take and cure herrings and white fish in all and sundry the seas, channels, bays, firths, lochs, rivers, and so forth, and for their greater conrenience to have the free use of all ports, harbours, shores, forelands, and others, for bringing in, packing, drying, unloading, and loading the same, upon payment of the ordinary dues where harbours are built,- - that is, such as are paid for ships, boats, and other goods; and discharges all other exactions, such as one night's fishing in the week, commonly called Saturday's fishing, under a penalty of L.100, any law, usage, or custom to the contrary notwithstanding. Clause second enacts, that all and every person cmployed in the said 
less than half an inch in thickness, or, if they are, that they shall be liable to seizure; and that, although by the Treaty of the Union certain clauses implied restrictions in the use of British salt for curing herrings and other fish, "full liberty was to be given to use such salt, or British salt, mixed with foreign salt;" but this Act most absurdly imposed the following duties on herrings used in this country : first, a duty of 1 s. per barrel of herrings consumed in Scotland; then, 3s. 4d. per barrel of Scottish herrings consumed in England; and imposed various restrictions and penalties as to the mode of using salt, which duties, restrictions, and penalties, must have been vexatious and oppressive, and tending to impede the progress of the fishery.

In 1757, the Free British Fishery Society applied by petition to Parliament, stating that they had expended L. $136,305,8$ s. 6 d., besides the produce of the fish caught and the amount of the bounties obtained, and requesting assistance from Parliament in the form of higher bounties, and the permission to use such nets as might be deemed most expedient. Parliament, accordingly, allowed the use of such nets as might be thought most advantageous by the company, and increased the bounty to $50 \mathrm{~s}$. per ton.

fishery on the coasts of that part of Great Britain called Scotland, or on the coasts of Shetland and Orkney, or any of the said islands, shall have and exercise the free use of all ports, harbours, shores, and forelands, below the highest water-mark, and for the space of 100 yards on any waste or uncultivated land beyond such mark, within the land, for landing their nets, casks, and other materials, utensils, and stores, and for erecting tents, huts, and stages, and for the landing, packing, curing, drying, and reloading their fish, without paying any feu-land or other dues, or any other sum or sums of money, or other consideration whatever, any law, statute, or custom whatsoever notwithstanding; and if any person or persons shall presume to demand or receive any dues, sums of money, or other consideration, or obstruct the fishermen or other persons employed in the taking, buying, or curing of fish, he or they shall forfeit L.100. 
These Acts, although necessarily authorising the expending of considerable sums of the public money, had a beneficial effect in directing the attention and the capital of the inhabitants of the kingdom to the herring-fishery. But although so much encouragement had been given or offered, in this year (1757) only L.8867 was paid in bounties, and in 1758 only 10,942 barrels of herrings were exported.*

It required some time to initiate those employed in the proper mode of fishing and curing; and, although the bounties were considerable (without reference to the impetus given), the number of people employed and the various materials used fully warranted the propriety of the application of the money. Such, however, was the mismanagement of the public revenues in Scotland in 1766 , that many of those who embarked in the fisheries were ruined in consequence of the neglect or inability of the public officers in Scotland to pay the bounties, while at the same time the bounties in England were regularly paid.

The bounties were truly looked on as hardly equivalent to the heavy duties on the raw materials required in the fishery, and in fitting out the busses, and to compensate for the heavy fees paid the custom-house and other officers; but the non-payment of the bounty was of most ruinous consequences to all those engaged in the fishery, and in consequence of this dishonouring of the bounty debentures, the number of the busses annually decreased. For instance, there were fitted out in-

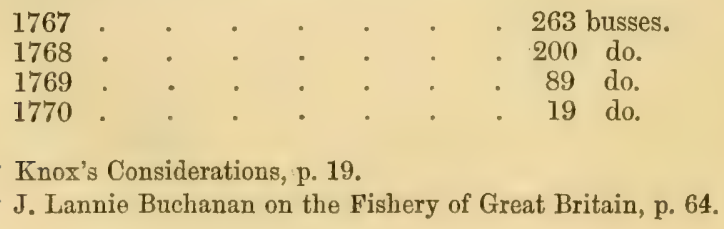


And, as is remarked by an able writer, "the patience and abilities of most of the adventurers being now completely exhausted, and the old bounties for a number of years still unpaid, the distress which existed amongst all classes so employed exceeded that of any former period."*

However, the bounties seem to have been subsequently more regularly paid in Scotland, for in one year the sum of L.31,396 was paid for bounties to the herring busses; but in the year 1771 the bounty was again reduced to 30 s. per ton.

Nuch information as to the herring-fishery in 1778 is given by Mr David Loch, General Inspector of the Fisheries, in a work in three volumes, on the "Trade MIanufactories and Fisheries of Scotlarid." In that year he made a tour to the west and south-east coasts of Scotland, and from him we learn that the herring-fishery was at this time, in some of the districts, of considerable extent and importance, and which had been brought into this state from the wise encouragement given by the nation to this important fishery. The following were the numbers of busses fitted out from the different ports on the west coast of Scotland in $1777:-$

\begin{tabular}{|c|c|c|c|}
\hline From & Port-Glasgow & 21 busses & $873 \mathrm{t}$ \\
\hline$"$ & Rothesay & 20, & 880 \\
\hline " & Campbelton & 62 & 2,780 \\
\hline " & other ports & 138 & 5,520 \\
\hline & & 241 busses & 10,053 \\
\hline
\end{tabular}

carrying about 3000 mariners, and bringing back considerable cargoes of herrings; and its importance may be seen from the fact, that from the west coast alone the following numbers of barrels of herrings

* Knox's Observations, p. 46. 
(each barrel measuring $31 \frac{1}{2}$ gallons, and containing from 700 to 900 herrings) were exported, used for home consumption, and sent coastwise, in the year from 1st April 1777 to 1st April 1778 :-

From Greenock.

Exported principally to the West Indies, . . 23,058 barrels.

Sold for home consumption, . . . 4 4,458 "

Sent coastwise, - . . . . . 919 ,"

From Greenock, total quantity, . . . . $\overline{28,435}$,

Prom Port-Glasgow, exported, . . . . 5,752 ", and here a considerable quantity was also sold for home consumption.

At Campbetton, in the same year, were exported, . . . . . 8377

Sent coastwise, . . . . . . 2204

Sold for home consumption, . . . 245

From Stornoway, exported, . . . . $\overline{2197}$

Sent coastwise, . . . . . 3964

From Isle Martin, red herrings, 500 and 800 per barrel, cured as at Yarmouth and Dunbar, - 12,000 , Total quantity, . . $\overline{63,234}$ barrels.

This large quantity of superior herrings, cured in only a few of the ports on the west coast, proves the beneficial effect of the bounty system in calling a latent benefit into actual and permanent existence.

The herrings were this year, 1777, abundant off Eyemouth and Dunbar, and were principally prepared smoked or red. Messrs Fall had this year at Dunbar nine red herring or smoking-houses, in which $1,200,000$ could be smoked at a time; and William Knox had three smokinghouses to prepare 300,000 ; Walter Simpson had two smoking-houses to prepare 200,000; Geo. Wilson \& Co., of Liverpool, had two smoking-houses to prepare 200,000; but the largest of all was at Eyemouth, belonging to Richard 
Turnbull \& Co., in which could be smoked 1,300,000. And this same year there were the following numbers of boats on the Fife coast in the herring-fishery,-viz., from Crail, 11 boats; Cellardyke, 15; Pittenweem, 4; St Monance, 15. But it is worthy of remark, that at this time none of the curers prepared red herrings in that part of the Firtl.

The Scottish herring-fishery had, however, no small difficulty to contend with in the fisheries which were carried on by other nations. At Gothenburg, and other parts in Sweden, a successful fishery had been carried on for several years, and the exports were considerably more than from this country; and it may be useful to give a comparative statement of the quantities exported from the two countries in the following six years, ending with 1781 :-

$\begin{array}{ccccc}\text { Herrings exported, } & & \text { From Sweden, } & & \text { This Country. } \\ \text { In } 1775, & \ldots & 94,594 & \ldots & 33,082 \\ " 1776, & \ldots & 128,467 & \ldots & 50,165 \\ " 1777, & \ldots & 132,046 & \ldots & 41,217 \\ " 1779, & \ldots & 135,085 & \ldots & 32,810 \\ " 1780, & \ldots & 106,664 & \ldots & 25,122 \\ " 1781, & \ldots & 136,649 & \ldots & 14,082\end{array}$

And besides the quantity sold fresh and smoked in Sweden, it was calculated that in one year 1,066,000 barrels of herrings had been boiled down in Sweden for the purpose of producing oil; the number of barrels of oil obtained from that quantity having been 44,000 , which were prepared at 429 oil-boiling houses, having in all 1812 boilers or kettles.

Although the fishery was flourishing in Sweden, Holland seems to have had fewer busses than before, for in 1784 there were only 270 busses sent from the ports of that country to the deep sea herring-fishery. 


\section{CHRONOLOGICAL HISTORY OF THE HERRING-FISHERY.}

When the bounty was diminished, the busses again annually decreased in number in this country, for in the year 1781 only L. 9674 were paid in Scotland for bounty, and in the years 1779 and 1782 no bounty was claimed for busses fitted out in England.*

And in the five years from 1779 to 1785 , notwithstanding all the expenditure of public money and the enterprise of private individuals, the herring-fishery, for want of sound legislation and judicious superintendence, had nearly ceased to be of any importance. We can account for this failure of the fishery to a considerable extent by the injudicious laws as to the times enacted for rendezvousing, and fishing, and the oaths required to be made; for the licenses to fish (which by statute were to be issued by the Commissioners of Customs) bore that the fishermen on the west coast were to proceed to the north-west Highlands, and the oaths were required to prove that the herrings were caught on the coasts of Scotland. These restrictions prevented the fishermen following the herrings to other quarters, and, as an intelligent writer of the time says, "filled the inhabitants of the coast with indignation against these self made legislators, after having in vain pleaded upon the obvious words of the statutes of their country." But that highly useful body the "Convention of Royal Burghs," in 1783 took the matter into consideration, and in a spirited memorial addressed to the Lords of the Treasury, brought them to a right conception of the statutes, and to issue a circular to the inhabitants, pretending to have misunderstood the law, and releasing them from such restrictions, - but only after serious injury had been done.

From the irregular manner of curing herrings on the

* Highland Society's 'Transactions, vol, ii. Dr Walker's Essay. 
Scottish coasts, no progress of any importance had hitherto been made. Although abundance of herrings might have been caught, the ignorance or dishonesty of the fish-curers in preparing inferior fish, packed in unfit or inferior packages, with inferior salt, prevented herrings from being received with favour either at home or abroad; and at this time it is extremely gratifying to find one of the most scientific and patriotic of our Scottish nobles suggesting the adoption of measures, which, having been adopted about a quarter of a century afterwards, have raised the herring-fishery to the highest state of prosperity. After fully discussing the different modes of making salt, and comparing the Dutch herring-fishery laws with our then existing laws, the Earl of Dundonald, in his able pamphlet "On the Manufacture of Salt and on the Herring-Fisheries," published 1784, says, "The Dutch, in supplying the diffe' rent markets, seem to pay attention to the condition the ' fish are in, to the purity and size of the salt, and to the " season of the year. No such attention is paid in Britain; "the season of the year, condition that the fish are in, "purity of the salt, all are disregarded, and, as the say"ing is, "all is fish with us that comes to the net;" and "this will always be the case until proper regulations be ' made and strictly enforced, and until by an alteration ' in the mode of granting, and by a diminution of the 'present extravagant and absurd, bounties, adventurers ' shall be obliged to catch and cure fish in earnest, and not ' to go fishing for the bounties.'

The wisdom of these remarks has been fully proved and established, the abolition of all bounties and duties having taken place, both wise and salutary laws and regulations having been made, and "strictly enforced," under the directions of a board of gentlemen acting gratuitously, 


\section{CHRONOLOGICAL HISTORY OF THE HERRING-FISHERY.}

with practical men as inspectors on the spot, watching that the abundant supply of wholesome food shall be properly cured and packed in sufficient barrels; and thus the ignorant or dishonest curer is prevented from destroying his own trade and profit, and made to prepare the herrings in the best and most scientific manner.

The encouragement offered by the bounties again brought a number of adventurers to fit out busses, the following being the numbers sent from Scotland in the eight years previous to 1784 :-

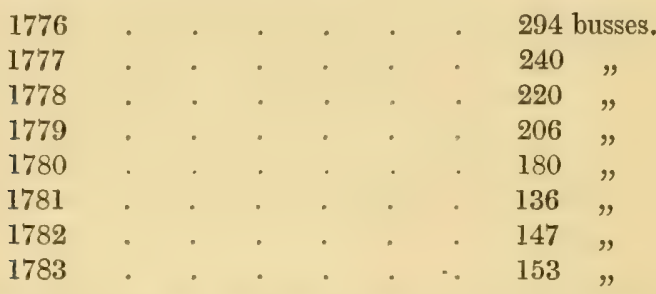

But again we see the number of busses gradually reduced, which we find to be owing to the many obstacles continuing in the restrictive laws and the large duties and fees imposed on the trade.

The system of high bounties having been found inadequate to promote the fisheries to the full extent, the important subject of endeavouring to establish a great patriotic undertaking became a national question. The desire was universal at this period to bring into full operation such a system as would give employment and food to a great portion of the population. For an average of some years not above 26,000 barrels of herrings had been exported. A committee was therefore appointed by the House of Commons in 1785, who examined many witnesses, and invited the opinions of those conversant with the subject. 
One of the most able works written at this time on the subject is by one of the leading merchants and curers in Scotland, of the celebrated name of Fall,-viz., Robert Fall of Dunbar,-and his shrewd and severe remarks on the Report of the Committee of the Commons, appeared in a pamphlet published in 1786 . He suggested the renewal of the bounty for buss fishing at the rate of 50 s. per ton, but proposed that $10 \mathrm{~s}$. per ton of this bounty should be divided among the captain and crew. He points out the causes of the failure of the bounty system, and objected to the compelling by statute each British buss of eighty tons to carry eighteen men, while the Dutch busses of a similar size had only twelve men.

He calculated that the Government had expended from the year 1751 to the year 1782, a period of thirty-two years, L.316,365 sterling, and recommends that the authorities should grant small sums to encourage boat fishing on the west and east coasts; and there is no doubt that he was correct in asserting that all those large sums given by way of bounty or premiums were repaid to the Exchequer in customs and excise duties, from the employment of the different materials liable to duty, and the consumption of articles liable to excise, consequent on the beneficial employment of the working-classes; and he gives an account to prove this, which was produced to the Committee of the House of Commons, by which it is shown that, notwithstanding all the bounties paid, the Government gained annually L.839s additional revenue.

As this account gives the rates and amount of money paid for bounties, and the duties paid, it is proper to insert it here. 
A State of Accounts between Government and the White Herring Fishery, by Mr Maxwell.

By duty paid on materials for buss repairs annually, - L.416

By do. do, hemp for repairing nets, . . . 320

By do. do. rum imported, in exchange for herrings, 12,236

By do. do. sugar do. do. do. 9,248

By do. do. salt used in curing herrings, . . . 162

By do. do. herrings consumed in Britain, . . 296

To bounty paid on 160 busses, at 30 s. per ton, L.12,280

L. 22,678

To debentures on 11,680 barrels exported, at 2 s. 6 d., . . . . . . . 1,460

To balance, being revenue arising annually from this fishery, . $\quad$. $\quad$. 8,938

$\longrightarrow \quad$ L. 22,678

Besides this yearly profit, he stated that the herringfishery gave employment to eighteen different kinds of tradesmen (which he enumerates), "affords freight for shipping, prevents emigration, and raises hardy seamen for the service of the state."

In the year 1786 the bounties on tonnage had been reduced to $20 \mathrm{~s}$. per ton; but the bounty of $4 \mathrm{~s}$. per barrel of cured herrings was continued with the understanding, that both the tonmage and barrel bounty should not together exceed 30s. per ton to each ship, unless the herrings taken exceeded three barrels per ton, in which case 1s. per barrel was to be allowed on the additional quantity caught. Encouraged by these bounties several vessels were fitted out by various enterprising individuals from Yarmouth; and eight vessels were also fitted out there, as far as possible in imitation of the Dutch busses. They were from fifty to eighty tons, and the value of each buss and its nets was about L.600; but, from some imaginary error or misconstruction of the Act, the payment of the boun- 
ties was the first year withheld by the officers of government. This was to be regretted, for the herrings caught by these ships were considered equal to the Dutch herrings, and arrived sooner at Hamburgh, and brought as high prices in that market as the early caught Dutch herrings.

The Custom-house fees were at this time (1786) oppressively high, and acted in a prohibitory way on the buss fishery. For instance, every buss paid Custom-house and other fees, -

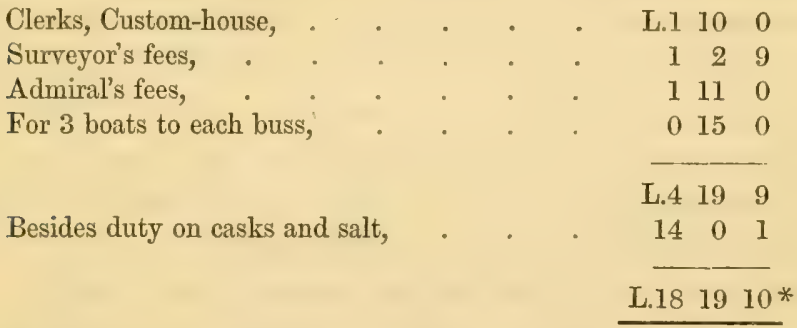

A Society was formed and incorporated by Act of Parliament in 1786, named, "the Society to extend the Fisheries, and improve the Sea Coasts of the Kingdom," which has been of essential service in affording facilities for the prosecution of the herring-fishery. $t$ The preamble of the Act 26 Geo. III. states, that ' the building of 'free towns, villages, harbours, quays, piers, and fishing 'stations in the Highlands and Islands of North Britain, ' will greatly contribute to the improvement of fisheries, 'agriculture, manufactures, and other useful objects of ' industry in that part of the kingdom in which the dis- persed situation of the inhabitants had hitherto proved

* Knox's Observations, p. 136.

† At the head of this Society was the Duke of Argyle, the grandfather of the present duke, and several of the nobility and gentry of Scotland were members. 
' a great impediment to their active exertions; and their ' being collected into fishing towns and villages would ' be the means of forming a nursery of hardy seamen for ' his Majesty's navy, and the defence of the kingdom.'

A capital of L.150,000 was subscribed, and a committee of this Society visited personally the coasts of Scotland, and resolved, after full deliberation, to purchase ground and build villages at Ullapool in Ross-shire, on the northern coast of Scotland; at Tobermory, in the Island of Mull, Hebrides; and at Lochbuy, on the western side of the Isle of Skye. At these places they soon afterwards not only built dwellings for the inhabitants, but also quays and harbours, as well as storehouses, where materials necessary for the fisheries might be deposited and sold to the people; and sums of money to the extent of L.100 to L.200 were lent to enterprising individuals to enable them to prosecute the fishery.

At Tobermory 2000 acres of land were obtained for the payment of L.500 for part, and L.78, 17s. of annual quit rent, and the sum of L.4032, 15s. 7 d. was expended in houses and quays. At Lochbuy 1474 acres of land were obtained for the small quit rent of L.49, 0s. 11d. per annum, and the Society expended L.1080 on schoolhouse, storehouses, and quays. At Ullapool 1031 acres were purchased for a quit rent of L.50, 9s. 11d., and the Society expended about L.5000 on a harbour; the total expenditure for it, the dwelling-houses, church, storehouses, \&c., amounted to L.7778, 4s. Sd.

The Society had subscribed or raised L.41,081, 5s. 8d., and expended L. $22,015,12 \mathrm{~s} .10 \mathrm{~d}$; and to induce the inhabitants of the neighbourhood to settle at these localities, building lots were given at the rate of $6 \mathrm{~d}$., $2 \mathrm{~d}$., $1 \mathrm{~d}$., per foot frontage of annual rent-garden ground from one- 
sixth to half an acre each on a lease of nineteen years, at an average rate of $12 \mathrm{~s}$. per acre-and ground to cultivate, to the extent of from four to ten acres, for thirty years' lease, at an average rate of $3 \mathrm{s.} 6 \mathrm{~d}$. per acre-and preachers and teachers were encouraged to settle at the different localities. It was afterwards found objectionable to let so much land at so cheap a rate, as it drew the attention of the fishermen too much from the fishery; and the Society, in certain cases, reduced the quantity of land given for cultivation, and raised the rate per acre.

The Society also encouraged the introduction of articles necessary for the fishery, by lending small sums to respectable settlers to purchase fishing materials, such as casks, nets, hooks, \&c., on condition that no higher profit was to be charged the purchaser than ten per cent.; and there is no doubt that the benevolent intentions of the Society has had a powerful influence in encouraging the prosecution of the herring-fishery.

At this time there was serious injury done to the herring-fishery by the illicit importation into Ireland of Swedish lerrings, and the British Society having applied to the proper authorities the trade was put a stop to.* The same Society interfered for the protection of the

* The fishery was so abundant, indeed, in Sweden in 1787 , that there were salted on the coasts there about 400,000 barrels, 4000 barrels smoked, and 4000 barrels pressed (into small compass); and calculating the quantities of herrings which were carried to Norway, Denmark, Holland, and Britain, as well as what was consumed by the inhabitants of Sweden, we shall not err in estimating that in that year there must have been fished about 1,500,000 barrels of herrings; and reckoning 1000 herrings to each barrel, the herrings having been of a small size, the total number of fish would be at least $1,500,000,000$ of herrings; and so much had the trade increased in oil-boiling, or boiling the herrings down into oil, that we are told by Von Wright, in his "Handlingar Rörande, Sillfisket," 1848, that at one oil-boiling establishment at Burgebosholm, there were produced 2000 barrels of oil. 
fish-curers in regard to the use of salt, the vexatious regulations regarding which much impeded the process of curing, and, accordingly, greater facilities were afforded the industrious curer.*

The bounties having been after this regularly paid, there were cleared out, preceding 1797, in the annual average of ten years, 300 vessels for the herring-fishery, the total tonnage being 14,736, and navigated by 3436 men. The average annual quantity of herrings cured was 54,394 barrels, and the tomnage bounty amounted to L.14,760, and the barrel bounty to L.6162,-together L.20,922, being about the rate of $7 \mathrm{~s}$. 6d. per barrel of bounty on the quantity cured; there was, besides, paid for barrel bounty on 70,428 barrels, the average annual quantity caught in the ten years, the sum of L.4792, making the total annual average quantity caught 124,822 barrels.

By the Act 35 Geo. III., the barrel bounty was increased to $2 \mathrm{~s}$. per barrel on such herrings as were caught by vessels, or boats not fitted out for the tonnage bounty.

The year 1793 was remarkable for the circumstance of the discovery of herrings in the Forth, proving satisfactorily that vast shoals may be visiting our coasts which are not yet discovered, and holding out every encouragement to active and persevering endeavours to find out localities periodically visited by the herrings.

In that year a considerable quantity was taken; and in the following year (1794) boats and vessels came from many of the ports on the coasts of Scotland; but the most successful fishermen and curers were from Campbelton, Rothesay, and Greenock. The advantages obtained by this great additional supply of food were found to be very

* General Account of the British Society for extending the Fisheries, by the Earl of Kinnoul. "Fraser's Domestic Fisheries," p. 95. 
great, and the inhabitants of London and all the large towns participated in the addition of a cheap supply of wholesome food, and a great accession of wealth and prosperity flowed into the torwns and villages on the shores of the Firth. The fishing commenced in October, and the fish were sold then to be used fresh; and the curers only began to salt or cure in November. The shoals formed an oblong square, from Burntisland to several miles westward on the north side of the Firth; and the herring's were caught in considerable quantities, the fishermen fishing day and night. The herrings returned in sufficient quantity to afford an abundant fishing for some years, until the middle of March; and several boats continued to fish until the middle of April, encouraged by the prices obtained for the herrings in a fresh state, which were sent by fast sailing vessels in boxes packed with ice to London. They were then of the size of from the eighth to the tenth class until January; after that month they became smaller and inferior, and the curer ceased curing about the end of that month in consequence of their inferiority. There were fishery officers attending to the efficiently curing of the herrings.

At this time the law enforced the packing of white herrings in oak barrels, which were then considered the best material, and by many it is still considered so,-but a heavy duty was then paid on foreign oak, which impeded its use ; and as to salt, so ignorant were the legislators of those days that, notwithstanding repeated applications and remonstrances, although English rock salt was found necessary for the purpose of being used to cure the herrings, it was then not allowed to be imported into Scotland; and the exactions in the form of fees to officers of customs and excise were exceedingly heavy, amount- 


\section{CHRONOLOGICAL HISTORY OF THE HERRING-FISHERY.}

ing on an average to upwards of twopence per barrel; and there were, besides, duties of $4 \mathrm{~s} .6 \mathrm{~d}$. per 100 bushels of salt, 1s. per barrel on herrings consumed in Scotland, and $3 \mathrm{~s} .4 \mathrm{~d}$. on herrings consumed in England, and $2 \mathrm{~s} .4 \mathrm{~d}$. per barrel on herrings brought into England from Scotland-so that while there was a bounty paid on buss fishing, which gave an apparent advantage to those who fitted out busses, there where heavy duties on salt and fish, besides the duties on raw materials, which were thus retarding the progress of the fisheries, and counteracting the ideal encouragement conferred on the fishing in the shape of bounties.

Nothing could exceed the lively and interesting sight of the herring-fishery in the various sea-ports and villages on the shores of the Firth at the time of the fishing during the few years the shoals returned. The little harbours filled with boats loaded with the silvery spoil, vast numbers of men and women conveying the herrings, gutting and packing, or putting them in the smokinghouses, gave a most interesting appearance to the busy scene; and in one small town, Burntisland, there were no less than twenty-two smoking-houses erected for smoking or making red herrings. But the want of judicious superintendence was the cause of the shoal being driven away; herrings, like other gregarious animals, are easily disturbed, and the fishing during the day fairly drove the shoals off in the course of time from their haunts.

In 1801 a Committee of the House of Commons was appointed to inquire into the state of the herring-fishery, which committee recommended, as the principal remedial measure, the total abolition of the duty on salt; but this recommendation was not adopted,-on the contrary, the duties on salt were raised. 


\section{CHAPTER II.}

FROM THE APPOINTMENT OF THE COMMISSIONERS OF THE BRITISH FISHERIES IN 1808 TO THE PRESENT TIME.

For some years previously the commissioners for manufactures and fisheries in Scotland, who had been appointed in 1726, had endeavoured to promote order in the fisheries, and had appointed officers, called fishing bailies, at different localities, who were of some use in this capacity; but until the passing of the Act 48 Geo. III. c. 110 , which took effect from 23d June 1808, little had been done to ensure success. The substance of said Act is as follows :-

1. Every vesssel employed in the British white herringfishery, from 60 to 100 tons, to be entitled to a bounty of L.3 per ton, and L.1 per ton additional to be allowed for the first thirty vessels fitted out the first year.

2. Bounties to the amount of L.3000 to be allowed by the commissioners for the herring-fishery to persons who shall employ boats of not less than 15 tons, and cure and pack the herrings according to the regulations of the commissioners. 
3. The larger vessels were to rendezvous at Bressa Sound on or before the $22 \mathrm{~d}$ of June, on which day they were to be inspected; but no nets were to be set before the 26 th of Jume, and the fishing to cease on the 15th of September.

4. A vessel of 60 tons was to have ten men; above 60 and under 70 tons, eleven men; and in proportion for every additional 10 tons; and of the crew two might be experienced foreigners. Each vessel to have on board, in new barrels, sixteen bushels of salt for every last of lierrings the vessel was capable of containing, and 300 square yards of netting for every ton of admeasurement; every mesh of the net to be one inch from knot to knot, under a penalty of L.40 and forfeiture of the net. The master had to state what port of Great Britain he intended to returm to and discharge, which was to be a port where a fishery officer was stationed, and the master was to keep a regular journal of his proceedings.

5. The nets to be shot and hauled from the vessel without the use of a small boat, the vessel not being at anchor while the crew were shooting or hauling the said nets, which were to be attached to the vessel when they were set, and the herrings to be cured on board the vessel in barrels, and not in bulk.

6. No custom-house cocket or sufferance was to be necessary if an officer of customs resided at the port.

7. A bounty of $2 \mathrm{~s}$. per barrel was granted on white herrings, gutted and barrelled the day they were caught, which date was to be marked on the barrel, each barrel to contain 224 lbs. of fish, exclusive of salt and brime. If for exportation they were to be repacked with great salt, the barrel containing $200 \mathrm{lhs}$. wet fish; and the in- 
specting officer was to certify that the herrings were not repacked till fiftcen days expired after they were first packed.

Any person convicted of making a false oath, or fraudulently marking any of the barrels, incurred a penalty of L.50, or six months' imprisonment.

8. The crew to receive from the owner of the buss a bounty of $2 \mathrm{~s}$. for every full packed barrel of herrings, of which $\frac{9}{8}$ ths was paid to the master, and $\frac{1}{8}$ th to the mate, and the remaining $\frac{5}{8}$ ths divided equally among the rest of the crew.

9. The number of trustees for manufactures and fisheries increased from twenty-one to twenty-eight, out of which his Majesty to appoint seven commissioners for the managernent of the fisheries, who appoint the fishery officers, subject to the approval of the Treasury, but they shall have been coopers and acquainted with the business.

The Admiralty was authorised to appoint a naval commissioned-officer to superintend, with such a force as should enable him to preserve order among the persons employed, and protect them from their enemies, to oversee the executive part of the whole fishery, at any time inspect storehouses or vessels, examine the certificates and journals of the masters, and the manner in which the herrings were cured; any person opposing this to forfeit L.100; and the juristiction of sheriffs, and stewarts'deputes, and their substitutes, is extended over all persons engaged in catching, curing, and dealing in fish, within their respective counties and stewartries, and also within ten miles of the coasts of their said counties and stewartries, in as full and ample a manner as the same is exercised over the inhabitants of these counties and stewartries.

Notwithstanding the high tonnage-buunties offered by P 2 
this Act, the many restrictions as to the time and place of fishing, the manning of the busses, \&c., seem to have entirely prevented the prosecution of the buss-fishery from Scotland; and from Eugland only five vessels, averaging 50 tons, were fitted out in 1814, and manned by fifty-nine men, which caught and cured 924 barrels of herrings ; and in 1815 only three vessels were fitted out in England, which caught and cured 624 barrels of herrings ; and only one from Scotland, of 84 tons and ten men, which caught and cured 153 barrels.

By the Act 55 Geo. III. 694, 14th June 1815, the Act of 1808 was altered, and so far continued and made perpetual, and a new and separate Board of Commissioners was appointed, and the Board of Manufactures, which had been erected in 1727, was made a distinct or separate Board for the encouragement and promotion of manufactures.

By this Act the barrel bounty previously referred to was repealed; and the bounty on herrings, if gutted with a knife, and cured and assorted in a sufficient mauner, to the satisfaction of the inspecting officers, was increased from 2s. per barrel to 4s. per barrel. Any herring-nets used in fishing on Sunday to be seized and forfeited. The barrels not to be made in whole or part of fir, to be half an inch thick, and to contain thirty-two gallons English wine measure.

The commissioners were authorised to fix the proper modes of measuring the fresh herrings sold,-viz., by the measure called the cran, by which the fishermen were paid.

Herrings not to be deemed gutted under the statute, unless gutted, cured, and packed within twenty-four hours after being taken, and to lie fifteen days in salt before being entitled to brand. 
Account of herrings cured on shore to be made out by the curer and given to the fishery officer, under a penalty of L.5.

Part of the bounty might be withheld on any barrels of herrings not gutted with a knife.

Herring's in barrels cured with fine salt, if under the weight of $235 \mathrm{lbs}$, free of pickle and salt, or if under 212 lbs., cured with large salt, not allowed to be exported, and if offered or entered for exportation, to be subject to forfeiture.

In case of dispute between officers and curers, arbiters may be chosen.

The bounties extended to ressels fitted ont to the fishing on the coasts of Great Britain, Ireland, and Isle of Man.

In terms of those two Acts before mentioned, the Cornmissioners of the Fishery Board issued, for the use and instruction of the curers, the owners, and masters of the busses, and of the fishermen, a distinct set of rules and regulations, directing in what form every journal, declaration, or account required to be kept or made, and fixing the different marks that were to be placed on the barrels when the horrings were packed. Nothing conld exceed the minute and accurate manner in which these rules were stated; and the Board was fortunate in having the services for such work of a gentleman of great experience and intelligence as secretary, namely, Mr Dunsmure.

While the British herring-fishery was encouraged, an attempt was also made to promote the fisheries in Ireland, and, in the year 1819, an Act was passed for the establishing of the Irish fishery, ${ }^{*}$ and a bounty of 50 s. per ton offered to all vessels fitted out in Ireland from 15 to * Irish Fisheries, 59 Geo. III. c. 109, 12th July 1819. 
60 tons for the herring or white fishery, and which should continue to fish for three months, or until a complete cargo of fish had been caught, with various proportional rates to be allowed for cured herrings and white fish.

And a further bounty was offered of L.3 per ton of oil extracted from white or other fish, and L.4 for every ton of whalebone taken on the coast of Ireland.

And also a bounty of 3s. per barrel on all herrings fished and cured on the coast of Ireland, and 4s. per cwt. on cured cod, ling, or other white fish, to be payable to all parties curing such, but not to those who receive the $50 \mathrm{~s}$. tonnage bounties; and the following clauses are very proper ones:-

Clause 15.- "And whereas shoals of herrings are frequently frightened from the entrance of the bays and creeks by vessels mooring, and shooting the nets at improper places, and by shooting long lines at the entrance of the bays and creeks, no vessel on the coast of Ireland shall moor or shoot nets or lines in any place forbidden by the inspector, under the penalty of L.20."

Clause 16.- "No net shall be shot or wet on the coast of Ireland during the day-time, under a penalty of L.10, nor at any time at any place, if forbidden by the inspector, under a penalty of L.20."

The other regulations were similar to those for the British herring-fishery, but these two clauses ought to be made perpetual and applicable to all the British coasts.

This Act was to be in force five years.

By another subsequent Act, 1 Geo. IV. c. 82, purporting to be for "regulating the fishery in Ireland, dated 24th July 1820, the Act of the 12th July 1819, as to the Irish fisheries, was altered in the following respects, - the 
bounty was increased from 50s. to L.3 per ton on vessels titted out from Ireland to fish herrings in the open sea, the vessels not being under 15 tons, or if exceeding 60 tons, the bounty was not to be paid on a larger number of tons than 60 tons.

Each such vessel was to be supplied with 2 barrels, 3 bushels of salt, and 335 square yards of net, for each ton measurement, as well as a suitable rope "to ride by the nets," and all requisite materials.

The crew were bound "to fish in the open sea," "and not in any bay, river, or loch," and to fish direct from the ship without the intervention of any small boat. And the vessel was not to anchor while shooting the nets, or while they were in the water, without sufficient cause shown. And the crew were to fish diligently for sixty days, exclusive of the Saturdays and Sundays, a sufficient part of every twenty hours of each of the sixty days, and were not to obstruct the crews of other vessels fishing, and were not to leave the fishing during the six ty days without cause shown, to be stated in the journal; and the herrings were not to be landed except in presence of an officer, and only once aweek, unless otherwise compelled by stress of weather or other cause.

The master was to keep a journal, to be verified on oath before being entitled to the bounty, with full particulars; and if the nets were injured from stress of weather or other cause, they were to be made complete at the first port of arrival.

The bounty given by the former Act of 3s. per barrel of cured herrings to be increased to 4s. per barrel; and, to be entitled to this bounty, the herrings were to be cured and packed within twenty-four hours after being caught. And all casks of herrings not properly cured in proper casks, if 
offered for bounty, to be liable to seizure; and each barrel was to lie fifteen days before being repacked. The herrings to be entitled to bounty were to be gutted by a knife, or the whole or part of the bounty might be withlield. No net was to have the meshes smaller than one inch from knot to knot; nor were any false or clouble nets to be used, under a penalty of L.40. And no herrings were to be packed in casks made of fir. 'I'hose ofiering herrings a second time for bounty to be liable in a jenalty of L.500; and a bond was to be given that the salt for the fishery should not be relanded. The Act was to continue in force for four years.

The tonnage bounty on busses, with the peculiar and improper restrictions enacted, did not prove suitable or advautageous, and the number of vessels fitted out gradually decreased; and on the 21st July 1821, the Act 1 and 2 Geo. IV., c. 79, was passed, abolishing the bounty of L.3 per ton on such vessels; and in this $\Delta$ ct were other clauses in reference to the appointmont of the superintendent of the fisheries on the deep sea and otherways, and as to the proper standard of the measure of herrings, called a eran, admitting the herrings caught at the Tsle of Man, or by boats from the Isle of Minn, to the bounty of 4s. per barrel, as paid on herrings caught off the other coasts, and received under the same regulations.

In 1824 the increasing success of the herring-fishery at Wick or Pulteneytown, rendered it necessary that it should be enlarged and made more safe for the numerous boats and vessels that resorted thither at the fishing season; and the British Fishery Society, which had already expended a considerable sum, as already mentioned, on the improvement of the place, commenced building an outer harbour.

The Act, 17th June 1824, 5 Geo. IV., c. 64 , gradually 
reduced and ultimately abolished the severil bounties and allowances from and after the 5th July 1825, which were payable at the time of the passing of the Acts on British and Irish caught herrings, and under the prescribed rules; and it enacts that the bounties should be amnually reduced as follows: for the year ending 5th July 18:6, the bounties were fixed to be $4 \mathrm{~s}$. per barrel; 3s. per barrel for the year ending 5 th July 1827 ; $2 \mathrm{~s}$. per harrel for 1828 ; and 1s. per barrel for 1829 , and thereafter to cease. The bounties were also by this Act abolished on cod-fish, ling, skate, sc., in the same manner and in the same series of years; and also the bounties allowed by Act 43, Geo. III., c. 69, on salmon, full red herrings, clem shotten red herrings, red sprats, pilchards, and scads, as well as the export bounties on pilehards and scads, in the same proportions and in the same series of years; but, at the sime time, hy clause eighth, all export duty on fish exported was abolished. By clause ninth, it is enacted that the L.3000 per amnum granted by the Act $4 S$ Geo. III., c. 110, to the Commissioners of the British Fisheries, and the L.5000 per amnum granted under the Act 59 Geo. III., c. 109, to the Commisioners of the Irish Fisheries, for the encouragement of the Irish fisheries, shall be applicel "in the encouraging" and assisting the buildiug, making, or repairing of piers or quays," as "shall appear to the said commissioners of the fisheries respectively to be most fit and necessary," and "for the repairs of boats of poor fishermen," "notexceeding the amount of L.500 in any one year in Scotland and Ireland respectively," muder the sanction of the T'reasury; reports of such appropriations to be ammally laid before l'arliament.

Most useful was this appropriation of the money for fishing harbours, at least in Scotland. The commissioners prepared a circular which was issued by their then secre- 
tary, Sir T. D. Lauder, of the most efficient but stringent nature. The rules embodied in this order are,-

1. That the money was only to be applied for the building of piers and quays, "for the accommodation of fishing" boats and other fishing craft, and not for any other purpose, or to piers or quays intended merely for the accommodation of general trade."

2. That those wishing assistance shall send to the commissioners plans and specifications of the proposed piers and quays, and stating what proportion the applicants are willing to contribute toward the expense of the work.

3. The secretary of the commissioners shall then report as to the utility of the proposed works for the purposes of the fishery, and if his report is favourable, that the Board shall send their engineer to examine and report as to the exact spot where the harbour or pier ought to be placed, and furnishing specifications and estimates of the expense. That these reports shall be examined by the Board before any promise of assistance is given, and before any contract is entered into. That part of the expense agreed to be paid by the applicants must be lodged in the Royal Bank.

4. That where money is allowed for such piers or harbours, all fishing boats and other fishing craft shall have free access to them without being liable for any port or harbour dues; and that before commencing the work a bond shall be given by the applicants to this effect.

However small the amount placed at the disposal of the commissioners, the application of it has been of the greatest benefit to the fishermen on the exposed and dangerous coasts of Scotland; and piers, quays, and harbours, have been built which would never have been erected but for the active exertions of the fishery officers in obtaining the 
necessary funds from the neighbouring proprietors, and in some cases from the hard earned gains of the fishermen resident at such places.

As some doubts were raised whether the Act 5 Geo. IV., c. 64, passed on the 17th June 1824, affected the application of some parts of the Acts previously passed, a new Act was passed on the 16th July 1830, 1 Will. IV., c. 54, explaining in how far previous Acts were to be applied, and enacting that old barrels bearing an old official brand shall not be again used for holding "any herrings or other fish," under the penalty of forfeiture of the barrels and fish contained in them; but that the laws and regulations applicable to the branding of barrels containing herrings should continue in full force. And a truly Irish clause in the Act is worth referring to, to show why the Irish fisheries were retarled, or not promoted,-namely, clause sixth enacts that the powers conferred on the "Commissioners of the Irish Fisheries" should be transferred to the "Director or Directors of Inland (!) Navigation." The wisdom of this change, and the fitness of "a director or directors of inland navigation,"may be very well questioned.

The subject of the food of the herring was at this time brought under the notice of the scientific world by $\mathrm{Dr}$ Inox, who read a paper at the meeting of the Royal Society, Edinburgh, on the 21st January 1833 ; but although much ability was displayed,--as may be seen in the essay published in the "Transactions of the Royal Society," vol. xii. p. 503, 1833,- - his assertion, that "the lierring lives on minute entomostraca or testaceous nicroscopic insects," has been found to be erroneous. Considerable discussion arose, and the assertion was ably controverted in some of the serials about the time of the problication of the elaborate paper by Dr linox in the 
Society's Transactions. There was also a series of letters by Dr Knox and the author in April, May, and June, in the Scotsman, which it would be too tedious to give here; but from the formation of the herring, and the examination of the stomach of numerous specimens at various localities, it will be found that the herring, like most other fishes, does not confine itself to any particular kind of food, as stated in this present work under the article "Food" and, as there stated, the opinion and experience of the author of the work was confirmed by the much more valuable opinion of the celebrated Agassiz, who told the author, when he met him at the first meeting of the British Association at Eclinburgh, that from the formation of the mouth of the herring, he was of opinion that this fish did not confine itself to any particular kind of food; and the examination of the food of the herring and other fishes since go far to prove this statement.

The new harbour at Wick or Pulteneytown while erecting, was greatly injured by a storm in 1827 , but it was at last completed in 1834 .

The successful prosecution of the herring-fishery at various places on the east coast of Scotland, under the protection and encouragement of the Fishery Board, encouraged other places where no fishery had been attempted; and the enterprising and laudable spirit of industry of the inhabitants of Aberdeen, induced the authorities at that port to offer facilities and encouragement to the fishermen to make the attempt to fish herrings off that coast. The first attempt was made in the year 1836, and it succeeded beyond the expectation of the most sanguine of the promoters; and about the middle of July, of the thirty herring boats which commenced, several caught to the extent of ten crans at a short distance from the shore. The herrings 
were generally all full, and of an equality of size, and well adapted for curing. The appearances were in every way indicative of the advantage of making Aberdeen a herring-fishery station, and the proximity of the harbour to the sea gives better facility than at many other places. At Fowlsheugh, wear Aberdeen, the appearance of many whales, porpoises, and aquatic birds, which sometimes follow the shoals of herrings, and thus indicate in some localities the presence of herrings, was very remarkable; and the procuring herrings of such superior quality so early on this coast is of great importance, because on the north side of the Moray Firth for instance, herrings are not generally fished to any great extent before the middle of August. At the fishing stations of Fraserburgh, Peterhead, and Banff, the quantities cured early in 1836 were also very satisfactory; and the advantages of steamers and railways must, no doubt, add greatly to the larger demand for this wholesome and cheap species of food, by enabling the purchaser to supply the wants of the most distant inhabitants of the comntry in a state of perfection, not previously seen at such a distance from the fishing stations.

In the year 1836 the fishing was later than usual on the Caithness coast, but latterly the quantity daily caught for a short time was considerable. We were so fortunate as to receive from the late talented poet, $\mathrm{Mr}$ Robert Gilfillan, who happened to be on a pleasure tour in Wick Bay, on the first successful night of the season, the following graphic account of the animated appearance off this important fishing station:-

"A more animated, and perhaps spirit-stirring scene could not be witnessed than the herriug-fishing on the coast of Caithness. This we enjoyed to the full extent on 


\section{CHRONOLOGICAL HISTORY OF THE HERRING-FISHERY.}

the evening of the 22d and morning of the $23 \mathrm{~d}$ August 1836, off the thriving town of Wick. This town may be considered as the grand emporium of the Caithness herring-fishing, and on this occasion it presented a scene of anxiety, bustle, and activity, which a partial appearance of improvement in the season's fishing, that hitherto had been almost a failure, at this time created. The evening of the $22 d$ was just such a one as the most experienced fisher could wish; a stiff, but steady westerly breeze slightly ruffled the waters, and occasional showers of rain gave hopes that the fish would be plentiful in the bay. Imagine, then, as the twilight settled in, trains of boats silently leaving the harbour, and forming, as it were, into tine along the coast for the watchful toils of the uight, and the consequent hopes and fears of the 'coming morrow.' Frequent and numerous as these trains were, no adequate ideas of their numbers could be ascertained, owing to the distance and darkness that soon surrounded them; still we were sure that their appearance on the morrow would be striking when crowded together under the favourable auspices of a morning sun. But no language can express our astonishment, when beholding from the deck of our ship, now moored outside the bay, the far extent of waters literally darkened with fishing boats, now busy in drawing the net, or pressing coastwards under the tawny sail. The aspect was at once novel and grand; and by no great stretch of the imagination, here was a fleet, tiny in detail, but imposing in the mass, which by a little magnifying power might be supposed to be some vast armament assembled to sweep the seas, or hurl their thunder on the devoted shores. From authority which we afterwards found to be correct, the number of boats proceeding to the shore was between seven and eight 
hundred; these were manned by four or five individuals each, which gives a compliment of upwards of three thousand men engaged in this hazardous enterprise. Although several instances of loss of life could be given as occurring in bad weather, we use the term hazardous in the commercial sense; and certainly, when we state that up to this auspicious day all their toil and watching had been productive of no success, it will readily be allowed that it is not misapplied. The cheers of the respective crews, as they passed us for the harbour, told that on this occasion they had not toiled in vain. On landing, and examining the various boats, we learned that the take might be from thirty to seventy crans each boat; indeed, one boat was shown with one hundred crans on board."

\section{"R. Gilfillan."}

To record the progress of the fishery in each year at the different places, would occupy too much space in a work of this kind; but it is useful and interesting to obtain well-ascertained facts as to prices, and quantities, and places, in certain seasons. The trade has been gradually extending, and the quality having been established under a system, the herring becomes a useful article of commerce, and the demand comes from distant quarters; and I shall take one locality to illustrate these remarks. At Wick, and the neighbouring ports of Thurso and Helmsdale, by the 31st of August there were cured and shipped the following quantities to the named places, making in all 69,653 barrels; and the freights are also stated as having been paid for the transportation of the herrings,-the price paid for the herrings having been at the moderate rate of 21s. per barrel:- 
240 CHRONOLOGICAL HISTORY OF THE HERRING-FISHERY.

Baltic and Continental

Freights.

Barrels.

\begin{tabular}{|c|c|c|c|c|c|c|c|c|c|c|}
\hline Ports, & . & 。 & 2 & 6 & to & 3 & 6 & . & & 16,928 \\
\hline Belfast, & . & . & 2 & 4 & to & 2 & 6 & : & . & 11,009 \\
\hline Bristol, . & . & . & 2 & 10 & to & 3 & 0 & - & & 2,605 \\
\hline Burntisland, & & • & 1 & 3 & & 0 & 0 & • & ${ }^{\circ}$ & 4,000 \\
\hline ork, & . & . & 2 & 9 & & 0 & 0 & & & 1,900 \\
\hline undee, & • & • & 1 & 3 & & 0 & 0 & . & & 830 \\
\hline ublin, & . & - & 2 & 4 & to & 2 & 6 & & & 5,650 \\
\hline undalk, & • & . & 2 & 4 & to & 2 & 6 & . & • & 1,820 \\
\hline rogheda, & - & • & 2 & 8 & & 0 & 0 & & & 1,450 \\
\hline irkcaldy, . & . & . & 1 & 3 & & 0 & 0 & & . & 3,900 \\
\hline irkeudbrigh & ht, & • & 3 & 0 & & 0 & 0 & - & . & 200 \\
\hline eith, . & . & . & 1 & 3 & & 0 & 0 & . & . & 2,150 \\
\hline iverpool, & & . & 2 & 0 & to & 2 & 3 & . & . & 3,730 \\
\hline imerick, . & & & 2 & 10 & to & 3 & 0 & * & . & 1,450 \\
\hline ondonderry, & & - & 2 & 4 & to & 2 & 8 & - & . & 1,230 \\
\hline arne, . & • & . & 2 & 8 & & 0 & 0 & . & . & 440 \\
\hline ilfordhaven & & . & 3 & 0 & & 0 & 0 & • & . & 420 \\
\hline Tewry, . & . & . & 2 & 4 & to & 2 & 6 & . & - & 4,850 \\
\hline ew Ross, & . & . & 3 & 0 & & 0 & 0 & - & . & 400 \\
\hline ort Rush, & • & . & 2 & 6 & & 0 & 0 & - & . & 750 \\
\hline ligo, & • & . & 2 & 6 & to & 2 & 8 & . & . & 1,300 \\
\hline Swansea, . & & - & 3 & 0 & & 0 & 0 & - & & 500 \\
\hline$N$ aterford, & & . & 2 & 8 & & & 10 & . & & 1,990 \\
\hline Whitehaven, & & . & 2 & 8 & & 0 & 0 & • & • & 250 \\
\hline
\end{tabular}

In a previous part of this work we have stated that the herring shoals sometimes present a bright luminous effect in the water and in the atmosphere; but such appearances do not seem to be so frequent as to teach the fishermen that they are near the shoals. For instance, in a letter. from the keeper of the lighthouse on Sumburgh Head, Shetland, dated 19th September 1836, published in the "Edinburgh Philosophical Journal," January 1836, No. 43, p. 192, after describing a severe storm from N.E., which drove the fishermen from the fishing ground, to the great loss of their nets and endangering their lives, it is 
stated that "a light appeared to the fishermen which greatly annoyed them; it appeared like a furmace standing in the water, and the glare of the light stood to a great height; it vanished by daylight, and appeared two nights ; it stood so near some of the boats, that the men thought of cutting from their nets to get out of its way." There can be no doubt whatever that this brilliant appearance emanated from a large shoal of herrings near the surface. Indeed, old fishermen on the south-cast coast are quite accustomed to the sight, but perhaps not to such a great degree of intensity as arose from the peculiar state of the sea and the atmosphere on the occasion mentioned.

In $18 \pm 1$ the herrings were rather abundant in several of the bays or lochs on the West Coast of Scotland. At Loch Carron there was a considerable quantity fished of full-sized herrings, and at Loch Torridon the quantity caught in July was considerable, first at Garvelean Island, and then the shoal of herrings proceeded gradually higher up. Such was the abundance of the shoal at Garvelean Island that the nets of one boat took 120 crans in one night. At Loch Sunart the fishing was also very large, and the quality of the herrings was superior to that of some of the neighbouring lochs; but at several other of these lochs the fishery was also equally productive.

On the East Coast of Scotland the quantity taken was generally satisfactory, and at Cromarty, where the herrings are very uncertain, the fisliery was so abundant that the boats averaged 300 crans each.

MIr James Wilson, the naturalist, who accompanied Sir Thomas Dick Lauder in an excursion round the Scottish coasts in 1841, thus describes the fishery of Wick in that year:-

"In the gray of the morning we found ourselves in the 
very thickest of the fight. Many crews were making large captures, hauling in their long extended nets glittering with fish 'as the dew of the morning,', or, as one of our sailors expressed it, 'going over the gunnel like a white horse ;' the surface of the sea scemed at this time dotted all over with small dark spots. These were the boats with their sails pulled down. As the nets are hauled they are also shaken, so as to cause all those herrings that are loosely meshed to drop into the boat, the rest being disentangled when they reach the harbour. While the boats lay at anchor by their nets they looked like motionless specks upon the water; and the effect was singular and very striking when they suddenly hoisted their canvas, as if emerging from the bosom of the deep, and shot away towards the shore, covering the now brightened surface far and near with a multitudinous array of sombre coloured sails. The same law regulates the morning as the evening fishery, and they are not allowed to cast again after sumrise. We then retumed to Wick Bay, and for an hour we enjoyed the sight of the countless boats returning laden with their scaly treasures."

\section{FISHERY CONVENTION ACT, 22D AUGUST 1843, 6 \& 7 VICT.} CAP. 79.

Disputes having arisen in the English Channel as to the rights and boundaries of the oyster fisheries of the coasts of France and South Britain, it was resolved by the Governments of the two nations that a convention should be entered into, and the same was signed on the $2 \mathrm{~d}$ August 1839. And to regulate the same, as well as the cod and liug and other fisheries, a commission was appointed, in terms of said convention, "tn prepare a set of regulations 
for the guidance of the fishermen of the two countriès." These regulations were prepared and agreed to by the commission, consisting of Messrs Anthony Perrier and F. Lange, and ratified by the two Governments, and an Act of Parliament was passed on the 22d August 1843 embodying these regulations. How far it was a wise and reasonable act on the part of the British Govermment to transfer the right of fishing herrings on the Scottish coasts beyond the limits of only three miles from the said coasts, instead of three leagues, the boundary maintained to be the legal and just distance, for the purpose of obtaining some hypothetical or fancied advantage for the English oyster fishermen, we shall not discuss here; but that very great and peculiar advantages were gained by the French nation by this convention, no one can doubt. The principal heads of this Act and Schedule of Regulations are-

The exclusive right of fishing on the coasts of the two nations are fixed at three miles distance from low water mark.

British and French fishermen are forbidden to fish within such limits.

A series of numbers shall be affixed to the fishing vessels of each country, with letters denoting the districts to which they belong; of the sizes indicated by the Schedule of the Act.

All the fishing buoys, and principal floats, and all other implements of fishery, shall be marked with the same letters and numbers as on the said vessels or boats.

The fishermen of both countries shall, when required, exhibit their licences and muster-rolls to the commanders of the fishing cruisers, and to all other persons, of either country, appointed to superintend the fisheries.

'Trawl fishing may be carried on hetween the limil: of the Q 2 


\section{CHRONOLOGICAL HISTORY OF THE HERRING-FISHERY.}

two countries at all seasons, but is prohibited in all places where there are boats engaged in herring or mackerel drift net fishing; and trawl boats shall at all times keep at a clistance of at least three miles from all boats fishing for herrings or mackerel with drift nets.

Herring fishing to be free all the year round. Herring nets shall not be less than one inch ( 25 millimetres) square from knot to knot along the line.

When decked herring boats and undecked herring boats shall commence shooting their nets at the same time, the undecked boats shall shoot their nets to the windward of the decked boats, except they should prefer going to leeward to a distance of at least half a mile to shoot their nets; but where the herrings are, and the observance of the preceding regulations permits, the boats of the respective "countries taking part in the fishing" may fish on the inner side or nearer the coast, but shall be responsible for damages. All fishing vessels and boats shall remain with their nets when set.

No boats to anchor where drift fishing is going on.

No nets of different boats when entangled shall be cut but by mutual consent.

All fishing boats and materials picked up at sea to be delivered up to the proper authorities, to be restored to the owners, who shall pay compensation to the finders, if the authorities find that they are entitled to it.

Commanders of cruisers shall detain those who infringe the regulations, and shall decide on such if deemed right; but if the party refuses to comply with such decision, the commander shall carry the boat or vessel into the nearest port, but no boats shall be detained more than four days, and they shall, if necessary, be sent to their respective countries, where the case shall be adjudicated. 
The fishing vessels of the one country shall not use the harbours of the other country for the greater convenience of their fishing operations.

Herring fishermen shall comply with the laws and regulations of the country where they fish as to the observance of the Sabbath-day.

Signed at London, 24th May 1843.

The harbour which was constructed at WVick or Pulteneytown, was in $18 \pm 4$ still found to be defective and insuffcient, and the British Fishery Society applied for and obtained, in 1844, an Act of Parliament authorising the construction of a third harbour; and the Act authorised the appointment of commissioners, for the purpose of managing the affairs of the port. It was foumd that the proposed addition to the harbour would cost L.26,000, a sum which the limited nature of the funds of the Society scarcely justified in expending, particularly as tho patriotic and noble-spirited men who were the shareholders, had only been paid eleven dividends of two per cent. in seventysix years. The Society, however, resolved to direct all its efforts to procure the requisite sum, for the purpose of so improving the harbour, as might render it more commodious and safe for the vast numbers of fishermen who resorted to the fishery; and, to obtain additional funds, the Society sold their properties at Lochbuy at a loss of L.1241, at Ullapool at a loss of L.2870; but at Tobermory at a profit of L.2300.

One or two curers having been discovered in attempting to pass off their herrings as entitled to the Crown brand, which herrings were either inferior in quality or not assorted, or the casks not of full size, had their herrings seized by the officers of the Fishery; or, what was also 
severe punishment, on account of the exposure, the pur. chasers were informed of the errors or fraud, and rejected the purchases made. In consequence of this an attempt was inade by the guilty parties to get the Board and their officers into odium. Some of the English members of Parliament, ignorant of the impossibility of carrying on the wholesale trade in hemings, of a marketable quality, without a continued surveillance of experienced men, as the fishery officers are, were induced to ohject to the maintenance of the Fishery Board, and the inspectors or officers; and it was thought necessary, in the year 1848 , to make inquiry as to the utility or efficiency of the Fishery Board. Accordingly, the Right Hon. J. G. S. Lefevre was sent to Scotland to inquire and report; and although he came to Scotland with no favourable intentions regarding the system, he seems to have been fully convinced of the great advantages of the system carried on; and his report fully proves that he, after the most careful inquiry and examination, was convinced that the system was useful, necessary, and tended to promote the success of the fishery. This report is as follows :-

"REPORT ON THE EXPENDITURE UNDER THE SUPERINTENDENCE OF THE SCOTCH FISHERY BOARD.

"LondoN, January 24, 1849.

"Sir,-In obedience to the wishes of the Lords Commissioners of Her Majesty's Treasury, that I should carefully investigate the expenditure conducted under the superintendence of the Fishery Board at Edinburgh, in order to ascertain how far each part of it is productive of 
public advantage, and whether any, and if any, what alterations are called for by the change of circumstances since the present system was first established, I proceeded to Edinburgh in October last, and addressed myself to the inquiry which the Lords of the Treasury desired to be made.

"In carrying on this inquiry, in which Mr J. B. Hume was good enough, with the sanction of their Lordships, to afford me his useful and voluntary aid as secretary, I received every assistance from the Board of Fisheries and their officers which I could desire.

"They gave me the most unreserved access to their minutes and correspondence, and the entire use of their office and clerks; and their secretary, Mr Primrose, in a spirit of integrity and impartiality which demands my grateful notice, used his best exertions to collect information for me, whether favourable or unfavourable to the continuance of the functions of the Board.

"The expenditure under the superintendence of the Fishery Board for the year 1847, including the annual grants made under the Act 5 Geo. IV. c. 64, for harbours and piers, and for materials towards the repair of fishermen's boats, may be thus classified:-

1. Expenses in relation to the office in Edinburgh,-

$\begin{array}{lcccrrr}\text { Salaries, } & \text { L.965 } & 4 & 0 \\ \text { Travelling expenses, } & \text {. } & \text {. } & 92 & 15 & 1 \\ \text { Law expenses, } & \text {. } & \text {. } & \text {. } & 15 & 10 & 9 \\ \text { Taxes, } & \text {. } & \text {. } & \text {. } & 118 & 11 & 1 \\ \text { Postage, } & \text {. } & \text {. } & \text {. } & 19 & 17 & 4 \\ \text { Contingencies, } & \text {. } & \text {. } & \text {. } & 6 & 11 & 6\end{array}$

2. Salaries and incidental expenses of the fishery officers on the East Coast of Scotland, . . . . 31851511

3. Ditto, fishery officers on the West Coast of Scotlaud, $1786 \quad 13 \quad 3$

4. Ditto, fishery officers on the Isle of Man, . . $\quad 133142$ 
248 CHRONOLOGICAL HISTORY OF THE IERRING-FISHERY.

5. Salaries and incidental expenses of the fishery officers in Bristol,

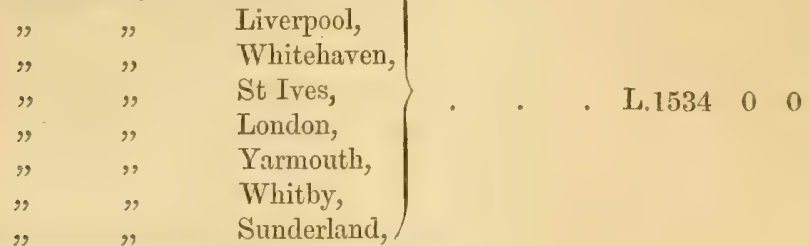

6. Travelling expenses of officers assisting at other stations during the branding season L.118 127

Allowances for extra duty, . . $\quad 62110$

Making and repairing branding irons, $\quad 4914 \quad 0$

7. "Princess Royal" cutter,-

Salary of commander, - . L.200 00

Wages of the crew, - . $593 \quad 57$

Victualling, \&e. . . $\quad$. $\quad 646 \quad 001$

Repairs and furnishing, . . $\quad \begin{array}{llll}445 & 7 & 5\end{array}$

8. Boat service at Wick and Loch Fyne,

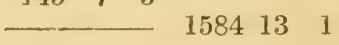

9. Remuneration to Naval Superintendents of Fisheries,-

Lieutenant Parks on East Coast, L.100 00

Lieutenant Morris on West Coast, $100 \quad 0 \quad 0$

10. Expenses in relation to the harbour grants,-

$\begin{array}{llrrr}\text { Salary of engineer, } & \cdot & \text { L.100 } & 0 & 0 \\ \text { Travelling expenses, } & \cdot & 77 & 10 & 11 \\ \text { Wages and travelling expenses of } \\ \text { local inspectors for superintend- } \\ \text { ing piers and harbours, }\end{array}$

11. Harbours,

12. Printing and stationery, . . . . .

13. Fee for new Fishery Bill, . . . . .

14. Retired allowances, . . . . . 117800

15. Materials for repair of fishermen's boats, . $\quad 500 \quad 0 \quad 0$

"I shall for the sake of convenience discuss, in the first place, the second of the above heads, $-i$. e., that which relates to the fishery officers on the East Coast of Scotland 
and the duties which they perform, and which are fully described in the annexed memoraudum prepared for me by the direction of the Board of Fisheries. That memorandum enables me to state that the principal duties performed by the East Coast officers consist of,-

"A. Those which relate to the branding of herrings.

" $B$. Those which relate to the branding and punching of cod.

"C. The prevention of illegal nets; illegal or improper fishing.

"D. A species of general superintendence over the persons engaged in fishing and curing, including the clearing out the fishing vessels when required, the enforcement of the law requiring the painting of the names on fishermen's boats, and more recently the enforcement of the provisions of the Act founded on the Fishery Convention between Britain and France.

" $\mathrm{E}$. The administration of the grants by the Commissioners towards repairs of fishermen's boats.

"F. The furnishing statistical and other information to the Board of Fisheries respecting the fisheries, and regarding piers, harbours, \&c.

"G. The enforcement of the law with respect to the size and materials of barrels.

"Of the above-mentioned duties, it appeared to me that those which relate to the branding of herrings first demanded my attention, inasmuch as if the continuance of that system were deemed expedient, the establishment by which it is conducted must of necessity continue, subject, of course, to any possible reductions. 
"At or previous to the commencement of my inquiries, various representations reached me, both from individuals and bodies of fish-curers, which led me to believe that the continuance of the system of branding was deemed to be objectionable by a considerable portion even of those who are in the habit of availing themselves of it; and some auxiety was expressed by the more distant fish-curers that I should personally visit Wick, and other places in the extreme north of Scotland, with a view to inform myself as to the opinions cntertained on this subject.

"The lateness of the season, and my other public engagements, prevented me from acceding to this suggestion; but in order to give all the fish-curers on the East Coast of Scotland, who alone used the brand, the opportunity of bringing their views before me, I addressed to them a circular letter which will be found in the Appendix hereto, containing certain queries, framed for the purpose of eliciting their opinions.

"From the answers to these queries, and from the oral replies of a considerable number of fish-curers and fishmerchants, whom I examined when in Edinburgh, I believe myself to have procured a body of information with respect to the effects of the branding system, sufficient to justify me in the statement and suggestions I am about to submit to their Lordships on that subject.

"I will first endeavour to give a brief account of the mode of curing herrings for the brand, and of the different kinds of brands applied.

"Mr Mitchell, the Belgian consul at Leith, in an essay published in the 'Quarterly Journal of Agriculture,' in Edinburgh, in June 1839, which was considered worthy of a medal, gives a succinct description of the mode of cure. I subjoin the following extracts:- 
" The herring's being brought in the boats alongside ' the quay, or near the curing place, are lifted with wooden

"shovels into a wooden measure without a bottom, called a ' cran (which measure is branded by the fishery officer, and 'must contain 36 gallons). The cran is previously placed ' on the cart or place where the herrings are to be de' livered, and upon lifting' up the measure, the same hav' ing no bottom, the herrings are thereby emptied out of 'it without the trouble of tumbling them out, as would ' have to be the case if it had a bottom. The herrings are ' then conveyed to the curing yard or shed, and are placed ' in square pits or in heaps; they are then gutted (almost " always now in Scotland with a knife), by taking out the 'gills and stomach, and those who cure in imitation of ' the Dutch leave the appendices coeci, or crown gut, as it ' is considered to impart a richer flavour to the herring; 'they are then roosed (sprinkled with salt), and, there' after, those employed in packing put a quantity of salt ' in the bottom of the barrel, and a layer of herrings is ' then closely laid together on their sides (if, in imitation ' of the Dutch, nearly on their backs); and, alternately, a 'portion of salt and a layer of herrings, until the barrel ' is properly packed. After remaining three or five days ' the barrel is again opened, when the herrings are found 'floating in pickle; the superabundant pickle is poured 'off, and an additional quantity of herring's to fill up the ' cask is packed in; a quantity of salt is then laid on the 'top of all, and the barrel is headed up, and it is then 'ready for branding. According to the existing British ' fishery laws, such barrels must be marked * * * to " show the month and day the herrings were taken, cured, ' and packed, and the mode of gutting' and the year, as 'well as the name and residence of the curer. 
CHRONOLOGICAL HISTORY OF THE HERRING-FISHERY.

* * * * * *

" " Each herring loarrel must not be smaller in capacity ' than 32 gallons, old wine measure, or 27 imperial gallons, ' and half-barrels may be used, if of proper size. The cask ' may be of any kind of wood (fir excepted).

* * * * * * *

"Before any cask of herrings can be branded with the

- Crown brand, they must lie fifteen free daysin the cask,' namely, the day of their being packed and barrelled, and ' the day they are presented for the brand, are not counted.

'Herrings for places out of Europe or the West Indies ' must be repacked; they must not be packed with the 'original pickle and salt, but must be washed, and then ' re-packed with fresh pickle and salt.'

"With regard to the different kinds of brands, the following description of them has been given to me by Mr Miller, the intelligent inspector of the East Coast Fishery.

"The Crown brand, No. 1, with the word 'Maties,' which is rarely used, is applied to barrels packed with the richest quality of well-cured gutted herrings, and from which fish full of milt or roe, and spent fish, are excluded.

"The 'Crown' ' full' brand, No. 2, is applied to barrels packed with well-cured, selected, gutted fish, full of milt or roe, and from which all tainted, spent fish, broken or broken-bellied fish, are excluded.

"The Crown brand, No. 3, is applied to barrels packed with well-cured, but unselected, gutted fish, free from all broken fish.

"The lozenge brand, No. 4, is applied to barrels containing herrings which were formerly Crown branded as 
above, but out of which the herrings have been removed, washed, and again packed into them, with a larger portion of great salt, preparatory to exportation out of Europe.

"The Crown brand, No. 5, with P. P., signifying twice packed, is applied to barrels re-packed with well-cured gutted herrings, prepared with great salt for exportation to places out of Europe.

"Of the several brands thus described by Mr Miller, the second, viz., the 'Crown' 'full' brand, is by far the most in use.

" Mr Miller gives the following statement of the brauding of 1846 :-

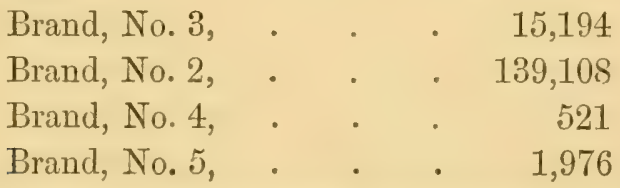

"He also states, that of the 139,108 Crown full branded barrels, 124,865 were exported; and, I may add, that this exportation almost wholly takes place to the northern parts of Europe south of the Baltic.

"The comparatively small quantity of re-packed branded herrings, No. 3 and No. 4, are for the most jurt exported to places out of Europe, and chiefly to the West Indies and Mauritius.

"The representations to which I have alluded as having been made against the continuance of the branding system adverted to the general objections to which such systems are liable. In reference to these objections, I may observe that the practice of stamping or branding articles of commerce by public officers, with a view to authenticate their genuineness or good quality, which existed in this country in respect of various kinds of goods, has, by degrees, been almost wholly discontinued. 
"It was found that, although it might secure to the purchaser that the article should not fall below a given standard, it tended to prevent its rising above that standard ; that it discouraged the improvements of private enterprise, inasmuch as it pronoted a uniform limit of price which it was very difficult to pass by any difference in quality.

"These, and other similar objections, have been stated in various forms by such of the fish-curers as have expressed themselves desirous that the system of branding herrings should be discontinued. These parties concur in the representation that it places upon the same level the careful and industrious curer, and the less careful and less industrious, inasmuch as the price of branded herrings at the same time and place is uniform, whoever may be the curer, and whatever may be the pains and care he bestows on the cure; and this important point is admitted by many of those who are favourable to the branding system.

"They further state, that the dealers who purchase at the fishery stations make their bargains, in the first instance, with those who cure their herrings not under cover, but in the open air, which is not so good a process, and who sell them at a cheap rate, and thus depress the price of the better article.

"They complain that whereas, in other kinds of business, industry, skill, and honesty have their reward in increased custom and better prices, this is not the case with respect to the exportation trade in cured herrings, owing to the levelling effect of the official brand.

"It is pointed out that, although the brand is by law nptional, and no one is compelled to obtain it, yet so long. as a considerahle number of the trarle use it, it camnot he 
safely dispensed with by the remainder; and that the delay and trouble necessarily occasioned by the conditions requisite to be fulfilled, produce some expense and inconvenience, and sometimes the loss of markets. They complain that the detention of the herrings during the fifteen clays required before they can be lawfully branded, leads to a large simultaneous export, which gluts the foreign market. Some of the witnesses, moreover, have stated that the export trade to Europe is over stimulated by the facilities to which I shall presently more particularly allude, and that exporters pay too little regard to the state of the demand in the continental markets, but export at all hazards; and as an illustration of this practice, they advert to the enhanced price of green, that is, uncured fish, and they assert that the curers are at the mercy of the fishermen. They refer to the increase of the redherring trade, and the improvements in that branch of cure to which the branding regulations do not extend, and which is conducted on the ordinary principles of competition, without the artificial aid of the Govermment officer, as a fair illustration of the result of placing the whiteherring trade on the like footing:

" On the other hand, I feel bound to state, that a very large majority of curers, measured both in number and in amount of herrings brauded by them, are decidedly favourable to the continuance of the brand, as compared with those who have expressed unfavourable opinions. Of those whom I orally examined, Measșrs MLethuen, Simpson, Robertson, and others, brand amongst them upwards of 50,000 barrels of herrings out of the total brand of 148,000; aud amongst the replies from the fish-curers to whom my printed queries were sent, those who irged the continuance of the brand (not including the parties 
orally examined) represented more than between 40,000 and 50,000 barrels.

"The facts and considerations adduced in the evidence favourable to the continuance of the brand appear to me to support the following propositions :-

"That of the branded herrings by far the greater portion go to Prussia, and the countries adjacent to the south of the Baltic.

"That (unless in the early part of the season) fer herrings are sent to these countries except under the sanction of the brand.

"That a high minimum of quality and cure is secured under the system of branding, not only by the refusal of the brand when the herrings are not duly prepared and cured, but because during the whole process of preparing and curing (a process so rapid in its operation, and carried on by such large bodies of persons, as to render it very difficult for each separate curer to watch over those whom he cmploys) the fishery officer circulates amongst those employed, examines from time to time the progress of their operations, points out defects in the cure or selection, and stimulates the negligent by warning them of the possible refusal of the brand. This service performed by the fishery officers many of the fish-curers notice as being particularly useful.

"That the brand has the full confidence of the merchants and consumers in these countries, a fact testified not only by the replies and evidence of the great majority of the fish-curers on the East Coast, and of the fish merchants whom I examined, but also by various representations from continental merchants, which will be found in the Appendix, No. 3.

"That branded herrings are accepted with little exami- 
nation, and pass from merchant to merchant and into the interior without the necessity of opening the barrel, except in comparatively few instances.

"That the brand prevents disputes as to quantity, quality, and cure, and especially those disputes which originate in a falling market, from a desire on the part of the purchaser to throw them back on the seller.

" That the currency (if such an expression be allowable) of the branded barrels facilitates dealings in them, and amongst other facilities it encourages advances on bills of lading, in which the articles being described as Crown fullbranded herrings are known to be of a definite quality, and readily saleable.

"That the brand being an authoritative declaration of the quantity, quality, selection, and cure, herrings can be and are ordered by foreign merchants more frecly than if such an authentication did not exist, and they can be, and are, purchased on the spot at the fishery station, without any previous knowledge of, or relation with, the fish-curer.

"That the discontinuance of the branding system might, at all events, temporarily alter the course of the export trade; that some time might elapse before confidence in the individual curers could take the place of the brand.

"That at first there might be distrust sufficient to occasion some diminution of the demand, which might be still further diminished, if (which is by no means improbable) any falling off in the cure by the inferior class of curers were to damage the reputation of British herrings in the continental market.

"That these results would be aggravated if an official Government brand for Norwegian herrings were estab- 


\section{CHRONOLOGICAL HISTORY OF THE HERRING-FISHERY.}

lished-a possibility which is arlverted to by one of the witnesses.

"That the existing state of the continent of Europe, and the diminution of the demand for white-herrings in Ireland, occasioned by the failure in the potato crop, render the present not a favourable conjuncture for making a change in the established system of the herring trade.

"The statistical information obtained from the annual tables presented by the Fishery Board to Parliament, which I here subjoin, bears strongly upon the policy of the branding system :-

"An Account of the Total Number of Barrels of White Herrings Exported to Ireland, to other places in Europe, and to places out of Europe, for the undermentioned Years :-

\begin{tabular}{|c|c|c|c|c|c|c|c|}
\hline \multirow{2}{*}{ Years. } & \multicolumn{2}{|c|}{ Exported to Ireland. } & \multicolumn{2}{|c|}{$\begin{array}{l}\text { To other places in } \\
\text { Europe. }\end{array}$} & \multicolumn{2}{|c|}{$\begin{array}{l}\text { To places out of } \\
\text { Europe. }\end{array}$} & \multirow{2}{*}{ Total. } \\
\hline & Gutted. & Ungutted. & Gutted. & Ungutted. & Gutted. & Ungutted. & \\
\hline 1831. & $\begin{array}{c}\text { Barrels. } \\
126,591\end{array}$ & $\begin{array}{l}\text { Barrels. } \\
1.866\end{array}$ & $\begin{array}{l}\text { Barrels. } \\
31,100\end{array}$ & $\begin{array}{c}\text { Barrels. } \\
\quad \ldots\end{array}$ & $\begin{array}{l}\text { Barrels, } \\
57,128\end{array}$ & $\begin{array}{l}\text { Barrels. } \\
813\end{array}$ & $\begin{array}{c}\text { Barrels. } \\
217,499\end{array}$ \\
\hline 1832 & 113,380 & 757 & 47,556 & $\ldots$ & 57,493 & 1,498 & 220,684 \\
\hline 1833 & 146,771 & 2,483 & 55,852 & ... & 66,510 & 477 & 272,093 \\
\hline 1834 & 72,682 & 1,278 & 34,050 & $\ldots$ & 49,493 & 1,302 & 158,808 \\
\hline 1835 & 167.252 & 1,708 & 48,451 & $\ldots$ & 58,143 & 839 & 273,393 \\
\hline $18: 36$ & 102,425 & 543 & 46,777 & $\ldots$ & 38,036 & 1,484 & 189,269 \\
\hline 1837 & 137,630 & 1,465 & 57,388 & $\ldots$ & 34,142 & 4,532 & 235,158 \\
\hline 1838 & 145,787 & 4,139 & 64,870 & $\ldots$ & 23,033 & 1,901 & 239,730 \\
\hline 1839 & 156,045 & 1,314 & 82,515 & $\ldots$ & 11,993 & 654 & 252,522 \\
\hline 1840 & 147,604 & 2,913 & 90,951 & ... & 8,295 & 372 & 250,137 \\
\hline 1841 & 186,747 & 1,206 & 91,069 & $\ldots$ & ... & $\ldots$ & \\
\hline 1842 & 161,340 & 3,907 & 119,366 & 770 & 6,336 & $\ldots$ & 291,800 \\
\hline 1843 & 125,521 & 2,249 & 181,853 & 100 & 3,793 & $\ldots$ & 313,516 \\
\hline $\begin{array}{c}1844 \\
3 \text { quarters }\end{array}$ & $\{113,747$ & 6,546 & 143,754 & $\ldots$ & 2,150 & 176 & 266,373 \\
\hline $\begin{array}{l}\text { of year. } \\
1845\end{array}$ & 124,086 & 2,941 & 113,648 & 30 & 2,273 & 215 & 243,194 \\
\hline 1846 & 98,346 & 4,238 & 148,339 & 24 & 4,171 & 594 & 255,714 \\
\hline 1847 & 99,610 & 3,080 & 142,532 & $\ldots$ & 3,700 & 1,259 & 250,181 \\
\hline
\end{tabular}


"Alstract of the Total Quantity of White-Herrings Brandul and Exported, in so far as the same have been brought under the cognisance of the Officers of the Fishery, from the 1st of June 1809, in the under-mentioned Years, when the System hitherto in force for the Encouragement and Improvement of the British Herring Fishery took place, distinguishing each Year, and the Herrings Cured Gutted from those Cured Ungutted:-

\begin{tabular}{|c|c|c|c|c|c|c|c|}
\hline \multirow[t]{2}{*}{ PERIODS. } & \multicolumn{3}{|c|}{$\begin{array}{l}\text { Total Quantity of Herrings } \\
\text { Cured. }\end{array}$} & \multirow{2}{*}{$\begin{array}{c}\text { Total } \\
\text { Quantity } \\
\text { of } \\
\text { Herrings } \\
\text { Branded. }\end{array}$} & \multicolumn{3}{|c|}{$\begin{array}{l}\text { Total Quantity of Herrings } \\
\text { Exported (incluãing Ex- } \\
\text { ports to Ireland, see } \\
\text { preceding Table). }\end{array}$} \\
\hline & Gutted. & Uugntted. & Total. & & Gutted. & Ungutted. & Total. \\
\hline & Barreis. & Barıels. & Barrels. & Barrels. & Barrels. & Barrels. & Barrels. \\
\hline 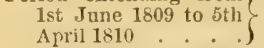 & 42,548 & $47,637 \frac{1}{2}$ & $90,185 \frac{1}{2}$ & 34,701 & $11,063 \frac{1}{2}$ & $24,784 \frac{1}{2}$ & 35,848 \\
\hline Year ended 5th April 1811 & 65,430 & $26,397 \frac{1}{2}$ & $91,827 \frac{1}{25}$ & $55,662 \frac{1}{2}$ & 18,880 & 19,253 & 38,133 \\
\hline " $\quad$ " 1812 & $72,515 \frac{1}{2}$ & $39,00 t$ & $111,019 \frac{1}{2}$ & 58,430 & 27,564 & 35,256 & 62.820 \\
\hline 1813 & $89,900 \frac{5}{4}$ & $63,587 \frac{1}{3}$ & $153,488 \frac{1}{4}$ & $70,027 \frac{1}{2}$ & $40,100 \frac{1}{2}$ & 69,625 & $109,725 \frac{1}{2}$ \\
\hline 1828 & 339,360 & 60,418 & 399,778 & $279,317 \frac{1}{2}$ & 210,766 & 893 & 211,659 \\
\hline $18: 9$ & $300,242 \frac{1}{2}$ & 55,737 & $3.5,5,979 \frac{1}{2}$ & 234,827 & $202,013 \frac{1}{2}$ & 3,062 & 205,875 \\
\hline 1830 & $280,933$. & 48,6231 & 329,557 & $218,418 \frac{1}{2}$ & $177,776^{\circ}$ & $3,878 \frac{1}{2}$ & 181,654 \\
\hline 1831 & $371,096^{-}$ & $68,274 \frac{1}{4}$ & $439,370 \frac{1}{4}$ & 237,085 & 260,976 & 3,927 & 264,903 \\
\hline 1832 & $313,113 \frac{3}{4}$ & $49,547^{2}$ & $362,660 \frac{3}{4}$ & $157,839 \frac{1}{2}$ & $214,820 \frac{1}{4}$ & $2,679 \frac{1}{2}$ & $217,499 \frac{3}{4}$ \\
\hline 1833 & $35: 3,68+\frac{1}{2}$ & $63,279 \frac{3}{4}$ & $416,964 \frac{1}{7}$ & $168,359 \frac{\frac{1}{2}}{2}$ & $218,429 \frac{1}{2}$ & 2,255 & $220,68+\frac{1}{2}$ \\
\hline 1842 & 489,6201 & $\mathbf{1 7 7}, 624 \frac{3}{4}$ & $667,245 \frac{1}{4}$ & $190,922 \frac{1}{2}$ & 283,530 & 1,206 & $2 \$ 4,736$ \\
\hline$" \quad$ " $\quad 1843$ & 442,290 & 181,129 & $623,419 \frac{3}{4}$ & 162,713 & $287,013 \frac{1}{2}$ & 4,757 & $291,800 \frac{1}{2}$ \\
\hline Period̈ extending from) & $473,556 \frac{3}{4}$ & 191,803 & $605,359 \frac{\pi}{4}$ & 182,988 & $311,167 \frac{1}{2}$ & 2,349 & $313,516 \frac{2}{2}$ \\
\hline $\begin{array}{l}\text { 5th April } 1844 \text { to } 5 \text { th } \\
\text { Jan. } 1845\end{array}$ & 393,312 & 132,7203 & $526,032 \frac{3}{4}$ & 140,632 & $259,651_{\frac{1}{2}}^{1}$ & 6,722 & $266,373 \frac{1}{2}$ \\
\hline Year ended 5th Jan. 1846 & 411,271 & 121,375 & 532,646 & $142,473 \frac{1}{3}$ & 240,008 & 3,186 & 243,194 \\
\hline " $\quad$ " 1847 & $414,915 \frac{1}{4}$ & $192,535 \frac{3}{4}$ & 607,451 & $156,278 \frac{1}{2}$ & $250,857 \frac{1}{2}$ & $4,856 \frac{1}{2}$ & 255,714 \\
\hline$" n$ & $372,989 \frac{1}{2}$ & 189,754 & $562,743 \frac{1}{2}$ & $146,500 \frac{1}{2}$ & 245,842 & 4,339 & 250,181 \\
\hline
\end{tabular}

"These tables appear to me to establish :-

"1. As to the foreign trade.-That the foreign trade in white-herrings, which, since the cessation of the West Indian demand in 1839-40, has been almost entirely confined, as before stated, to the North of Europe, south of the Baltic, and now almost wholly consists of Crown full branded herrings, has very largely increased since 1833 ; and I may here add, that several of the wituesses whom I examined were sanguine as to the further extension of the trade, and as to tho increasing reputation of Scotch branded herrings, and expressed their hope for the aid of 
her Majesty's Government in influencing other States to reduce their import duties on this article of commerce.

"2. As to the home herring trade, including Ireland. -That the unbranded trade, which includes the ungutted herrings, and consequently a large and increasing number of white herrings, subsequently made into red herrings, has increased very largely; whereas the branded trade in the home market has diminished, and is of little importance.

"After giving my best attention to the facts and considerations which I have above set forth on both sides of this question, I deem it my duty to state, that if the question of continuing the brand related only to the home trade in white herrings, there appears to me not to be adequate grounds for supporting it; but, as respects the foreign trade, which is sufficiently large to be an object of the highest importance to Scotland, the branding system forms so essential a part of its arrangements, its abandonment might cause such derangement and contraction of that trade, and consequent loss and inconvenience to those engaged in it, and to the large bodies of the working classes employed, not only in fishing, but in the various operations of curing for the European market, that I feel compelled, notwithstanding the objection in principle to which it is liable, to recommend that it should still be maintained, and, as a necessary consequence, that the establishment of the East Coast Fishery officers should be continued.

"I am disposed to think, however, that it may be worthy of consideration, whether it may not be advisable to charge a small fee or duty upon the branding of each barrel. This would throw a portion of the expense of the establishment upon those who immediately benefit by it, 
and would thus lessen what is, in effect, a bounty on the export white-herring trade, at the expense of the other classes of the community. It would likewise encourage the enterprising curer to rely on his own brand, as the saving of this fee or duty might counteract the disadvantage of his contending against the Government brand.

"I have confined myself hitherto to the discussion of the system of branding herrings only, because the punching and branding of cod, including in that term ling, tusk, and hake, which form another part of the duties of the fishery officers on the East Coast, is a system of comparatively small importance. Cod are punched by an instrument which cuts out a small defined portion of the tail of each fish which appears to the officer to be prepared according to the regulations and directions of the Fishery Board. The brand for cod is applied to barrels of cod properly pickled.

"The quantity of dried cod officially punched has, since 1843, beeu gradually diminishing; and in the year ending 1st January 1848 , only 8145 cwt. were officially punched out of $\$ 6,624$ cwt., being less than one tenth, aud only 955 barrels of pickled cod received the official brand.

"If these small amounts are compared with the total quantity of cod taken in the fisheries of Great Britain only, as ascertained by the fishery officers, and set forth in the account of the Fishery Report for 1847, the total caught will be found to amount to $413,730 \mathrm{cwt}$. ; the total branded or punched, 9100 cwt.

"Moreover, out of the 8145 cwt. officially punched, כ500 cwt. were from the Shetland Fisheries, and 1850 cwt. from the Orkney Fisheries; so that, of the remainder of the Scotch Cod Fisheries, only 1000 crt., out of 40,000 cwt. of dried cod, received the punch. 
"These statistical results show that the continuance of the system of punching or branding cod cannot, like the system of branding lerrings, be justified on grounds of national importance, or as involving the interests of large classes of persons.

"Entertaining a strong opinion, on the grounds before stated, with reference to the herring brand, that the system of authenticating the quality of goods by the agency of a Government officer is objectionable in principle, I think that it would be much to be regretted if any opportunity should be permitted for the growth and extension of a system of this mature, which is at present very limited, that is, the punching and branding of cod. Its discontinuance would now be easy; but if it were to come into general use the same difficulties would arise in terminating it which now exist in the case of the herring branding system. I must further state, that although on the East Coast of Scotland the extension of the punching: of cod might not create an increase of the Fishery officers, yet on the West Coast it would require more to be kept up than would otherwise be necessary. Accordingly, I venture to suggest that the system of punching and branding cod may be discontinued, subject to such precautions, in Orkney aud Shetlaud, as the interests and requirements of these islands, to which I shall more particularly allude on a subsequent occasion, may render advisable. (See Appendix.)

"Before quitting the subject of branding, it is proper that I should remark, that the extent to which the brand is used must not be regarded by any means as indicating the whole of the services or utility of the Fishery officers as to the preparation and cure of fish.

"A considerable number of barrels of herrings are cured 
as for the brand, although it is not applied for unless they are intended for exportation.

"Mroreover, the curer who uses the brand cures his fish together, whether intended to be branded or not; and the Fishery officer, from time to time, inspects the process, and endeavours to prevent defects and to promote improvements.

"In estimating the advantage or disadvantage of the branding system, this indirect effect of it must not be lost sight of.

"Having arrived at the conviction of the necessity of maintaining at present the system of brandiug herrings, it appears to me that this would of itself require the continuance of the Fishery Board, independently of the question of the general utility of that establishment. I conceive that the superintendence of that system, and of the officers conducting it, could not be better or more satisfactorily exercised than by that Board, which is thoroughly conversant with the subject as respects the Scotch fisheries, to which the branding system is practically limited, and far more conveniently situate than any central Board in London.

"Had I deemed it right to recommend the abolishing" of the system of branding herrings, it would have been my duty to have entered upon the task of weighing the value of the remaining functions of the Board against the expenses of its establishment. Although relieved from this question, yet having had the opportunity of inspecting the correspondence and proceedings of this Board, it would be unjust not to take this opportunity of adverting to the important services which the Commissioners, acting themselves gratuitousiy, and with a moderate establishment, have rendered to the puhlic, in assist- 
ing for a long period of years in the development of this branch of national industry, and of expressing my belief, that in the present condition of the poorer classes in Scotland, the question of the continuance of the Board of Fisheries is not merely to be regarded in reference to measures of economy, - that it is impossible to doubt the social and moral advantages which may and do result to this class of the population from the attention bestowed upon their welfare by a body of eminent persons distinguished by their rank, position, and knowledge, and who are constantly endeavouring to obtain and disseminate information useful to those employed in the fisheries, to cncourage their enterprise, to stimulate their industry, and to promote their physical and moral welfare.

"Although sensible of the value of the Fishery Board, and of the advisability of its continuance, I confess that I think considerable reduction and economy might be made in the expenditure under its control without impairing its efficiency. I allude especially to the possibility of considerably diminishing the number of the West Coast officers, and gradually discontinuing altogether the officers employed in England; and also to the making improved and economical arrangements for the naval superintendence of the fisheries, both with regard to the vessels of war and the fishery cutter. Upon these and other points involved in this subject, regarding some of which I desire further information, I shall offer suggestions in a separate Report, a course which I venture to adopt to avoid the inconvenience of delaying the expression of my views as to the principal matters in the case,-namely, the continuance of the branding system and the Fishery Board.-I have the honour to be," \&c.

(Signed) "John George Shaw Lefevre." 
4 th Dec. 1850.-The great abundance of young herrings coming among the sprats in certain seasons, afforded an easy supply to those indolent fishermen, at some localities, who did not follow the legitimate mode, and consequently these men prepared nets with small meshes, which encircled a great proportion of the young; or fry, of the herring, threatening the destruction of the proper sized herrings. The Board having had many complaints from different quarters, even from the fishermen who fished the herrings in a legal manner, wished to put a stop to such illegal fishing, and directed their several superintendents to apply the Act 48 Geo. III. cap. 110, which prohibits using such nets, under a penalty of L.20 and the seizure of the nets; and as fishermen were enabled the more easily to escape the penalties, in consequence of the boats or fishing vessels not having the name on them, the Board, of this date, directed a notice to be given to the fishermen, that if the boats had not the name printed on them in legal form the same would be seized.

By the Act of 24th July 1851, 14 and 15 Vict. cap. 26, the law which required the cured white herrings to lie in the casks for fifteen free days was repealed, and the commissioners empowered to fix any other period, and they accordingly reduced the time to ten days. In this Act a penalty is applied to the illegally branding empty herring barrels as well as full barrels; and, by this Act, the law is repealed which required that herrings exported to places out of Europe should be repacked with great salt. And it repeals the law prohibiting the exportation of herrings in barrels under size, if shipped before the expiry of the ten days after being packed, or in salt unbranded.

It is also enacted by sect. 6, "That wherever the herring fishery is commenced or carried on,' no other 


\section{CHRONOLOGICAL HISTORY OF THE HERRING-FISHEIY.}

nets shall be used than the usual drift nets; and if any others are used for trawling or otherwise, or found in the possession of any one on shore, or on board ship, the same shall be liable to forfeiture. And by this Act no baskets are permitted to be used in measuring and delivering fresh herrings, but such as are one fourth of the legal cran measure, or an integral portion of such measure, under the penalties applied to the using crans of illegal measure.

The early fishing of herrings at the Lewis Islands had become by this time of some importance, although the nature of the herring, from their peculiar richness and diffculty of cure, makes the business rather hazardous. Such herrings generally, however, if in good condition, obtain high prices when brought early to market; for instance, a cargo of new herrings arrived at Stettin on the 21st of May 1851, and sold for from 13 to 15 rix-dollars, or from 39s. to $45 \mathrm{~s}$. per barrel; but by the end of July 5700 barrels had arrived at Stettin, and the price had declined by that time to 8 rix-dullars, or $24 \mathrm{~s}$. per barrel. But so large is the demand for the interior of Germany, that 105,500 barrels of Scottish herrings were imported into Stettin in 1851, besides 26,500 barrels of Norwegian herrings.

We have already referred to the attempt to interfere with the system of superintendence and inspection under the Fishery Board; and in strong confirmation of $\mathrm{Mr}$ Leferre's Report, we are glad to refer to the accompanying letter addressed to George Traill, Esq., M.P., in 1851, from one of the principal merchants in Stettin, distinctly proving, that if the system is departed from, the demand for the article will decline, and the fishery be injured, and gradually destroyed:-

"Sir,-I would have fulfilled my promise much sooner, 
and have given you the desired information regarding the herring trade of our port, had I not been unwell since my arrival here; but, having recovered so far, I take this opportunity of stating that the official brand of Scotch Crown and Full branded herrings obtains the greatest confidence, not only in our market, but also in the interior of Germany, where the meaning of that brand is understood; and my firm belief, and also that of other people engaged in this branch of business is, that it would be injurious to the trade should the brand cease to exist, for Scotch herrings are only sold in small quantities in this market and the neighbourhood; they are chiefly sent great distances of from 100 to 800 miles English, into the interior of Germany and Poland, either by orders or offers, without the assistance of commission merchants, for the great expense of forwarding them does not permit any commission to a third party. The great distance prevents, likewise, dealers from inspecting the herrings on the spot here, who therefore make their purchases solely on their trust in the official brand, knowing that the fish must be selected well and properly cured-that the barrels be of the legal size-and that they require to be well and tightly made before the brand can be affixed.

"These herrings are generally forwarded by crafts, which are often six to eight weeks on their passage, and it frequently happens that a great fall in the market takes place during that time, and, should the official brand be removed, dealers in the interior might easily take advantage of such falls, for it would not be difficult to find complaints, - such, for instance, that the fish were not properly selected or well cured, that the fish had too much or too little salt, or that the barrels were of a smaller size (for no one can then say of what size the barrels require to 
be); and as most herrings are sold on credit, they would, consequently, be often stored at the risk and the expense of the shipper, and, perhaps, in markets where that person who purchased them is the only dealer.

"When a party purchases Crown and Full branded herrings at present, he is bound to receive them, if they bear that brand, independent of the quality; and our courts of justice have frequently given their decision in accordance with this statement, upon the ground that the British Fishery Board is a Government establishment, and, therefore, reliance can be placed in their impartial inspection and strict superintendence.

"Part of the present business consists of consignments by the curer in Scotland, who receives an advance when the herrings are shipped; and my opinion is, that this advance will cease to be given as soon as the official brand is removed, as our merchants here are then unable to judge what proceeds they will receive out of them when sent to the interior; and, consequently, the Scotch curer must feel it seriously whenever this brand is taken away, as he would not be able to embark so much capital, and from him it must show its influence upon the fishermen, and those people connected with the fishing.

"Norwegian herrings are not cured under the superintendence of the Norwegian Government, and as no reliance can be placed in their quality, they are seldom or never sent to the interior, but are chiefly consumed here and in the neighbouring provinces, from whence dealers are able to proceed for an inspection; and hence Norwegian fish are generally more diflicult to be sold than Scotch. At some places in Norway local Boards have been formed, and herrings shipped from these ports find quicker sales, and are also sent to the interior. 
"The sale of Norwegian herrings greatly depends upon the prices of Scotch fish, for when the price of the latter is low, the former is more difficult to be disposed of ; and even people of this place and those of the neighbouring provinces prefer Scotch herrings to those of the Norwegian cure, because the fish is of a superior quality, better cured, and the barrel contains more fish.

"Dutch herrings are in cure better than Scotch, but the difference between the two sorts is too great in price, and therefore Scotch herrings find the preference.

"The cheapness and the improved cure has increased the importation of Scotch herrings into our port to a great extent, for there is no port to which more Scotch herrings are shipped than Stettin, whilst the importation of Dutch and Norwegian fish has diminished, for we have imported in the year 1834, 4546 barrels of Dutch, and 53,891 barrels of Norwegian herrings; and have imported last year only 568 barrels of Dutch, and 12,507 barrels of Norwegian; whilst the importation of Scotch herrings has increased from 19,000 barrels in 1834, to 116,538 barrels in 1850 . In the year 1849 it even amounted to 147,103 barrels.

"Enclosed I beg to hand you the import list of herring"s into the port of Stettin, from the year 1824 to 1850 .

"According to my opinion, it will be injurious to the trade in Scotland if the British Government should insist upon the trade to pay for the Brand; for the cheaper herrings are, the greater distance they can be forwarded, and the larger the consumption will be, because herrings are a substitute for meat, and have therefore to stand a competition in price with that of provisions, as beef, bacon, $\& c$. , in the interior of the country.

"The first few shipments of Scotch umbranded herrings 
are only consumed by the richer class of people in Germany, whilst Croun and Full branded Scotch herrings are purchased by all classes; and hence it often happens that unbranded Scotch herrings are unable to be sold when the former are to be had; or, at any rate, a difference of from $3 \mathrm{~s}$. to $4 \mathrm{~s}$. sterling per barrel is made in the price, although the quality may be the same in every respect; and this is merely caused because the brand prevents disputes, and its quality can be relied on.

"Other articles in casks, such as oil, butter, \&c., can be sold according to sample, or their quality and contents can be stated; but such is not the case with herrings, for it is impossible to describe each fish in each barrel, or their number, and neither how the cure has been effected, nor whether they have been cured immediately after their capture, which is essential, because the fish may look well at first sight, but will not keep if not cured immediately after being caught.

" IIow could the trade in Germany be protected if the superintendence of the British Fishing Board ceased to look after this? As long as this Board keeps up its present character, there is no fear for a decline in the importation of Scotch herrings into Germany, but it is probable it may still increase, when charges, such as river dues and transit duty, are removed; and a larger trade might also be carried on with Poland, Prussia, and Austria, when the import duties into these countries are reduced.

"The import duty on all kinds of herrings into the Confecterated States of Germany (Zollverein), is at present one dollar per barrel, or equal to about 3s. sterling per barrel.

"Austria charges 2 gulden 30 kreutzers per cwt., 
making it about $15 \mathrm{~s}$. sterling per barrel, which is nearly the price of the fish in Scotland, and therefore a prohibition.

"Russia makes a difference in the tariff between Scotch and Norwegian Herrings; the former paying an import duty of 1 ruble 30 cops. silver, per barrel, or equal to about 4s. 6d. sterling per barrel, whilst Norwegian herrings are only charged 35 cops. silver, or equal to about 1s. 3d. sterling per barrel. The duty in Poland was formerly lower on Scotch herrings, but has been raised to that of Russia since the first of January 1851, and the Scotch trade has lost by that means a good market.

"For France, the duty is said to be 37 s. to 40 s. sterling per barrel, or more thian double the price of the fish in Scotland.

"The Belgian duty ranges from 12s. to 15s. sterling per barrel,* and in Naples it is almost as high.

"From Spain and Portugal Scotch herrings are altogether excluded, if I am rightly informed. The transit duty on herrings in Russia is 10 silver groschen, or equal to about 1s. sterling per barrel on the river Oder, as well as Vistula, and on the river Elbe it is only $2 \frac{1}{2} d$. per barrel.

"Holland charges about 3s. sterling per barrel for the transit of herrings on the Rhine.

"Denmar\% levies a duty of 3d. sterling per barrel on herrings for passing the Sound; and

"Hanover charges one-halfpenny per barrel for passing the Elbe at Stade. $\dagger$

"In conclusion, I beg to remark that I consider it would be a great benefit to the trade if the number of days which Scotch herrings must be in salt before the official brand can be affixed were reduced from fifteen to ten clear days, by which the shipments of branded fish would be facilitated, 
and a larger quantity could be disposed of to the interior of Germany before winter sets in.

"Should you require any further information, I shall be happy at all times to be able to serve you with it; and I remain respectfully, sir, your obedient servant,

\section{(Signed) Alexander Wellitann.}

"Stetrin, the 8th February 1851.

" George Traili, Esq., M.P., London."

Importation of Herrings into the Port of Stettin.

\begin{tabular}{|c|c|c|c|c|c|c|c|c|c|c|c|c|c|}
\hline \multirow{2}{*}{\multicolumn{2}{|c|}{ 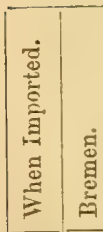 }} & \multirow{2}{*}{ 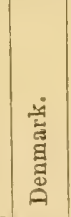 } & \multirow{2}{*}{ 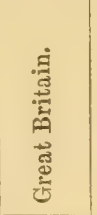 } & \multirow{2}{*}{ 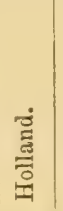 } & \multirow{2}{*}{ 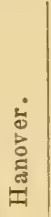 } & \multirow{2}{*}{ 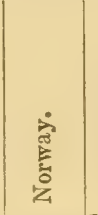 } & \multirow{2}{*}{ 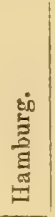 } & \multirow{2}{*}{ 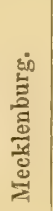 } & \multirow{2}{*}{$\begin{array}{l}\text { so } \\
\text { है } \\
\text { हूँ }\end{array}$} & \multirow{2}{*}{ 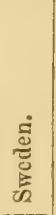 } & \multirow{2}{*}{ TOTAL. } & \multicolumn{2}{|c|}{ Imported. } \\
\hline & & & & & & & & & & & & More. & Less. \\
\hline \begin{tabular}{l|}
824 \\
825 \\
826 \\
827 \\
828 \\
829 \\
830 \\
831 \\
832 \\
833 \\
834 \\
835 \\
836 \\
837 \\
838 \\
8399 \\
840 \\
841 \\
842 \\
8433 \\
8444 \\
8845 \\
8846 \\
1847 \\
848 \\
8849
\end{tabular} & $\begin{array}{c}25 \\
\ldots \\
\ldots \\
\ldots \\
\ldots \\
\ldots \\
\ldots \\
\ldots \\
\ldots \\
\ldots \\
12 \\
30 \\
72 \\
36 \\
44 \\
12 \\
\ldots \\
18 \\
211 \\
\ldots \\
\ldots \\
\ldots \\
\ldots\end{array}$ & $\begin{array}{r}1300 \\
1960 \\
226 \\
3373 \\
6135 \\
1294 \\
779 \\
841 \\
199 \\
334 \\
599 \\
4111 \\
3837 \\
2163 \\
890 \\
994 \\
933 \\
\ldots 9 \\
103 \\
638 \\
2594 \\
307 \\
395 \\
1671 \\
402 \\
924 \\
470 \\
\end{array}$ & $\begin{array}{r}15,468 \\
18,160 \\
7,695 \\
15,082 \\
13,478 \\
14,449 \\
33,866 \\
13,077 \\
31,837 \\
31,711 \\
19,060 \\
26,875 \\
28,227 \\
36,309 \\
40,209 \\
49,456 \\
73,949 \\
50,732 \\
62,135 \\
143,659 \\
105,097 \\
81,189 \\
104,372 \\
112,260 \\
103,402 \\
147,103 \\
116,538\end{array}$ & $\begin{array}{r}4422 \\
4595 \\
3802 \\
4712 \\
2756 \\
4546 \\
1943 \\
2137 \\
6722 \\
4491 \\
1059 \\
2141 \\
850 \\
3397 \\
1119 \\
990 \\
2457 \\
179 \\
348 \\
196 \\
1313 \\
568\end{array}$ & $\begin{array}{c}\ldots . \\
\ldots . \\
\ldots . \\
\ldots \\
\ldots \\
16 \\
\ldots \\
138 \\
240 \\
288 \\
309 \\
134 \\
\ldots \\
144 \\
180 \\
\ldots \\
\ldots \\
\ldots \\
\ldots \\
\ldots \\
\ldots\end{array}$ & $\begin{array}{r}1,030 \\
6,758 \\
6,915 \\
9,948 \\
16,008 \\
28,485 \\
29,137 \\
21,924 \\
56,979 \\
77,758 \\
53,981 \\
39,730 \\
31,798 \\
77,851 \\
51,761 \\
46,282 \\
82,914 \\
43,433 \\
48,240 \\
44,092 \\
97,127 \\
44,264 \\
54,733 \\
42,828 \\
23,903 \\
26,962 \\
12,507\end{array}$ & $\begin{array}{c}\ldots . \\
\ldots \\
\ldots . \\
\ldots \\
\ldots \\
\ldots \\
\ldots \\
\ldots \\
\ldots \\
\ldots \\
\ldots \\
\ldots \\
\ldots \\
\ldots \\
\ldots . \\
\ldots \\
\ldots \\
\ldots \\
\ldots \\
580 \\
\ldots \\
\ldots\end{array}$ & $\begin{array}{c}\ldots . \\
\ldots . \\
174 \\
\ldots . \\
\ldots \\
\ldots . \\
\ldots \\
\ldots \\
\ldots \\
\ldots \\
20 \\
\ldots \\
\ldots \\
\ldots \\
408 \\
154\end{array}$ & $\begin{array}{c}\ldots \\
\ldots \\
\ldots \\
\ldots \\
\ldots \\
\ldots \\
\ldots \\
\ldots \\
\ldots \\
\ldots \\
\ldots \\
\ldots \\
\ldots \\
\ldots \\
547 \\
\ldots \\
\ldots \\
\ldots \\
\ldots \\
\ldots \\
\ldots \\
\ldots \\
\end{array}$ & $\begin{array}{c}\ldots . \\
\ldots . \\
\ldots . \\
\ldots . \\
\ldots \\
\ldots \\
\ldots \\
\ldots \\
\ldots \\
\ldots \\
\ldots \\
\ldots \\
\ldots \\
\ldots \\
\ldots \\
\ldots \\
\ldots \\
\ldots \\
101\end{array}$ & $\begin{array}{r}1,997 \\
31,133 \\
19,810 \\
33,587 \\
42,904 \\
48,650 \\
68,377 \\
39,644 \\
93,894 \\
112,559 \\
78,324 \\
72,899 \\
69,287 \\
123,280 \\
97,515 \\
97,863 \\
159,973 \\
95,203 \\
119,946 \\
189,662 \\
205,826 \\
125,845 \\
159,679 \\
157,107 \\
128,483 \\
176,512 \\
130,184\end{array}$ & 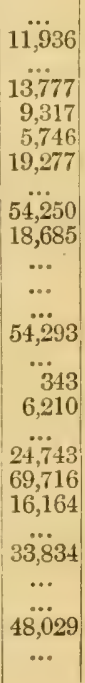 & 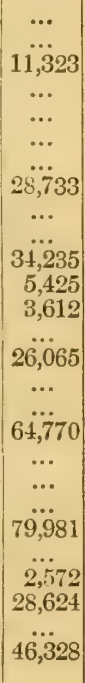 \\
\hline
\end{tabular}


1852, Crans and Barrels.-Before the establishment of the Fishery Board, the fishermen, when selling their herrings, were often liable to be defrauded by the measure not being of the proper size, and various orders and regulations were issued by the Board on the subject; and in consequence of the law fixing a standard measure of capacity, the Board found it necessary to issue, on 15 th May 1852, an order as to the changing the measure, or rather the denomination of its contents. The contents of the crans or barrel-measure of fresh herrings, before the measure of capacity was changed, was 32 gallons per barrel, and 16 gallous per half barrel, English Wine Measure ; and the order fixes the same measure to be continued as containing $37 \frac{1}{2}$ gallons, Imperial Standard Measure, in the cran or barrel, and so in proportion for the half. The Board, moreover, orders that the said cran or measure shall be made of oak staves completely seasoned, three-fourths of an inch in thickness, neither more nor less; the staves not to be under 2 inches, nor more than 4 inches in breadth, and no croze* to be allowed; that the cran shall be bound with six good iron hoops, of the following dimensions,-namely, the hoops at the extreme ends of the cran to be 2 inches in breadth, those on each end of the bilge to be $1 \frac{1}{2}$ inch in breadth, and those on each quarter thereof to be $1 \frac{1}{4}$ inch in breadth, all of proportional thickness; that the bilge hoops shall be so placed as to leave a space not exceeding 9 inches between the two; and the order further directs the placing of iron rivets to fix the hoops, and permits twelve holes to be bored to allow the water to escape, as well as the placing of handles for the convenience of the trade,- - such measure to be inspected by the fishery officer, and braurled, if found correct, and of the size and capacity described in the said order.

* Circular incision to receive the heads or ends required in bands. 
274 CHRONOLOGICAL HISTORY OF THE HERRING-FISHERY.

And the Commissioners further require that the barrel in which white herrings are packed shall be of the capacity or contents of $26 \frac{2}{3}$ gallons Imperial Standard Measure, and the half barrel $13 \frac{1}{3}$ gallons, both being the exact relative measure of the herring barrel and half barrel previously in use.

And parties using different crans or barrels are to be prosecuted.

Iredand. - Destruction of Herring-Spaun - BeamTrawting.-While every wish has been manifested by the Fishery Commissioners of Ireland to promote the herring and other fisheries on the coast of Ireland, it is to be regretted that the supply in the year 1852 had not improved, and that the system of beam-trawling was exciting serious disturbances in certain quarters of that country. The Report in 1852 by the Commissioners, dated 20th May 1853, says:-

"At Howth, and the East Coast generally, the harvest fishery for lerrings continued to a period later than usual. Several of the Cornish vessels remained up to the close of October; and among the extraordinary events which may be mentioned, was a large export of fresh herrings by train from Dublin to the Galway market. This circumstance has been attributed, in several announcements by the local press, to the indolence and indomitable prejudices of the Claddagh fishermen, and to the insufficiency of their means of capture. We have, however, good reason to believe that it was mainly owing to a deficiency of supply since autumn, and to the extreme severity of the weather. The Inspecting Commander of the Galway district states, 'that the condition of the fishery establish'ment is very much worse than the preceding year, and 
' that there are no signs of improvement whatsoever, but 'the contrary.' IIe adds, 'that the habits of the fisher' men are very disorderly and quarrelsome, unless allowed ' to do exactly as they please.' We regret to state, that having made several visits to Galway during the autumn, we are obliged to confirm this statement.

"The Board having been urged by some respectable persons, who wished to promote peace, to alter the limits for trawling in the Bay of Galway to a line drawn 'from 'Spiddal to Black Head,' determined, before they should hold any public meeting for the purpose of hearing evidence, to cause practical examination to be made, under the direction of an intelligent coast-guard officer, recommended by the late Inspecting Commander; and with the permission of one of the managing directors of the Royal Irish Fisheries Company, then trawling in the Bay, he accompanied one of the vessels in several trips, and closely examined the produce of each shot of the trawl, but could observe nothing resembling the spawn of fish.

"The Board having been desirous to obtain all possible information on this very embarrassing question before they should adopt further restrictions, determined that one of the Inspecting Commissioners should visit Torbay. It would have been quite uscless to make the proposed change, as nothing short of closing the whole Bay against trawling, \&c., from the Arran Islands inwards, would satisfy the unreasonable demands of the Claddagh fishermen; and a communication has recently been made by the Commissioners to the Government, expressing their conviction that nothing lut the constant rresence of a small armed steamer will secure the preservation of orler, as they fear that nothing else can break down the spirit 
of insubordination, the result of prejudices, which prevails. Happily it is the only part of Ireland in which there have been any disorderly proceedings; and out of forty district returus, there are but two in which the fishermen are not represented to be 'orderly, quiet, and 'peaceable, neither quarrelling among themselves, nor ' molesting strangers.'

"In the first case, it has been stated that the unfortunate and progressively declining community at the Claddagh can alone be charged with a habitual spirit of insubordination. The other case is more to be wondered at, because it is in the immediate vicinity of the metropolis. We greatly regret to state, that during the last season several aggressious have been committed upon the boats and nets of the Cornish fishermen, both at Howth and Kingstown. Active measures were adopted by the coast-guards and constabulary, and every aid was afforded by the local magistracy to discover the offenders. A large reward was offered by the gentry and by the Board of Public Works, as Commissioners of Kingstown Harbour, for the discovery of the offenders, and we are especially indebted to Captain Symonds, the late Inspecting Commander, for his active assistance; but all was in vain, the offences were committed at night, and no discovery has been made. But, though fruitless, we must say, every exertion towards the discovery of the offenders was made by the harbour-master of Howth, who has uniformly rendered great service to the fishery, in the regulation and preservation of order in that harbour, now become decidedly the most important fishery station on the coast of Ireland. That most exemplary body of men, the crews of the Cornish fleet, are very casily managed; but when upwards of 200 sail of vessels are assembled, and the 
whole of their fish is daily sold, it requires no ordinary exertion, great judgment, and local knowledge, to prevent frauds and to repress outrage. The markets of Dublin were abundantly supplied through the season; and to that circumstance, generating a spirit of jealousy and monopoly on the part of the trawlers and line fishers, may have been attributed the aggressions committed against the Cornishmen. The bye-law of the 14th February 1851, obliging the trawlers to keep off the shoal ground on the eastern coast, has been most gratefully received by the Cornish fleet; and to it, in a great measure, they attribute their extraordinary success last year. We have resolved upon using increased precautions this year, and confidently hope that we shall be able to prevent any recurrence of impropriety."

And as we consider the talented Inspecting Commissioner Barry's Report as to the fisheries on the Devonshire coast and regarding beam-trawling extremely valuable, as bearing upon the question of legislative interference, and as there is much interesting information besides, we do not hesitate to give large extracts of this Report.

\section{COAST OF DEVON INQUIRY.}

Fishery Office, 15th November 1852.

"Sir,-On the 18th of August last, it was resolved by the Board, on reading my Report of the 18 th June, that I 'should proceed to the coast of Devon, for the purpose ' of collecting information bearing upon the question of ' trawling, and the laws, usages, and regulations in force ' relating thereto, and that when the Commissioners were ' in possession of my Report, they would take into con'sideration the propriety of holding a meeting at Galway 
'to receive evidence as to altering the limit at present ' defining the trawling ground at Galway.'

"Having been prevented ly an unusual pressure of business in the office from immerliately undertaking this important mission, I determined to occupy the time in making such preliminary arrangements as should facilitate my inquiries; and I have to express my best thanks to the Collector of Customs in Dublin, and to the Inspecting Commander of Coast-guards of the district, for their kind co-operation in furuishing me with valuable introductions to Exeter, Torquay, Brixham, and Dartmouth.

"My next course was to communicate with some of the fishermen of Galway, and with some respectable persons there, interested in their behalf, informing them of my intended visit to the coast of Devon, and soliciting their aid in inducing the fishermen of the Claddagh to select some intelligent person of their own body to accompany me, and to be present at the several investigations which I proposed to make, so as to be able to authenticate any statements which I should be cnabled to make in reference to the practice and regulations observed by a community so prosperons as the fishermen on that coast. With this object, I visited Galway twice within the month of September, and finally obtained from one of the gentlemen who undertook to negociate the matter with the fishermen, a letter bearing date the $23 \mathrm{~d}$ September, conveying a direct negative to the proposition. I subjoin a copy of Mr Wade's communication :-

“GALWAY, September 23, 1852.

"MIy DEAr Sir,-According to your wish, I went into 'the Claddagh village, and spoke to two men of intelli'gence and substance, and, as I considered, men who 
' have some influence with their fellows. They declined

' my proposal to go to Torquay,-first, because they might ' lose the herring-fishing here, and, also, they did not " relish the idea of being implicated in the introduction "of trawling in this bay. This latter objection they ad' mitted freely to me. They have boats of their own ' suitable for the work, but they fear the vengeance of 'those who have nothing to lose. They say that in one ' week, after their return from England on such an errand, 'they would be without a boat. I did not go farther, as

'I well know the people, and feel convinced that no

'amount of eloquence would ever change their long'rooted prejudices. I was near catching it the other ' evening for allowing my dog to run on board a boat 'ready for sea; so that you have two powerful elements ' to contend with-superstition and prejudice. But with "all this, they are a hardy race, and there are some good " men among them. I have not much doubt that if there 'were sufficicnt constant protection given by the Govern' ment, you would see, before twelve months, many of ' themselves trawling in the bay. There are forty to fifty 'boats here, from twelve to fifteen tons, which would suit ' the purpose, and some only require to see the thing well ' established, when, I am convinced, they would quickly ' follow. What is required then, in my humble opinion, ' is a small war steamer in the roads, always ready for sea, ' with sufficient boats attached to go up the shallow bays ' and creeks, to protect those who will work and not idle. - When the herrings are in season, at present the custom ' is, first to ascertain whether the self-created lords of the 'bay intend to go out to fish. If they are in the mood to 'go, then all may take their chance; but if they say No, 'then, monstrous to say, the many industrious men who 
'would try their luck, must obey the mandate, and lose 'often the best fishing nights. This occurred a few ' nights since, when some country boats stole a march on 'them, and had a fair take, though they only made one 'shot. The rascals heard of it, and no doubt would have ' roughly handled them, but they could not find either 'them or the herrings. The same thing occurred with ' myself. This is a most deplorable state of things. The ' bay is literally alive with herrings and mackerel, but the ' take is so trifling, it is only sufficient to supply the town. 'They have never exceeded two nights in the week. As 'I mentioned the steamer, I had better suggest to the ' Board the necessity of establishing a small force in 'shore, right among them, who would very quickly mark 'down the most turbulent of them, and keep them in 'most effectual check-for at best they are cowards, and, ' like all cowards, soon overawed. It is my impression 'that such a proceeding would be warmly welcomed by "those who have anything in the shape of boats and ' tackle to lose; they would be glad to be protected from 'the lawless, beggarly rabble, who are the instigators of 'all the mischief. It is known that, long since, the ' latter class determined, when they caught Mr Synge's 'trawler at a disadvantage, to scuttle her and drown the 'crew; but, fortunately, the affair got wind, and no ' atternpt was made; but if they get opportunity, when "the autumn fishing is over, and poverty and starvation ' staring them in the face, then their vengeance will turn ' on those who, they do not hesitate to say, have de'stroyed their fishing. In almost all their acts with ' regard to Galway Bay fishing, they set the law at 'defiance; and until they are taught by force to obey the ' law, no good can be got from them. When they find 
'force won't do, and feel that others are reaping the ' harvest they ought to gather, then, perhaps, kindness, ' and, if possible, assistance to enable some of them to ' get the necessary tackle to go to sea, and provide them' selves with sufficient provisions for a week or ten days, ' you, my dear sir, may depend on it, that a very short ' period would elapse until you would see them once more ' comfortable and happy. If Government would only ' consider the subject, and extend a helping hand in time, ' the thing could be easily done, and a large class of men ' saved from the workhouse and jail. For after all that ' has been said of them and against them, with scarcely ' one redeeming trait, yet they are goor fishermen, and 'very many among them would jump at any employ that ' would put bread in their children's mouths.

" If I can be of any assistance or service in carrying 'out such a laudable work, I shall be most happy to 'render all in my power to save them from impending ' ruin; for there is not at this moment in the village one ' dozen spillets, or one dozen boats, able to take sufficient 'provisions to sea for a fortnight, and all this when the ' cod and round fish are just coming in.

" I was induced to write you thus fully on the subject ' from our conversation to-day. You know the people, ' and so do I; and I really hope the Commissioners, in ' recommending the Executive to send cannon balls, will ' also not forget to send the means of earning bread. 'Should this letter have any weight, then I have no ' apology to make for my suggestions; but I hope that ' you will not feel I have inflicted a long and useless ' letter on you. And am, my dear Sir, yours very truly, “'To J. R. Barry, Esq." (Signed) 'Thomas WADE.' 
"I left Dublin on the evening of Saturday the 9th of October, and reached Bristol the following evening. There I learned that the chief supply of fresh fish to that important market is received from the coast of Devon, by the Bristol and Exeter and the South Devon Railways. The trade is exclusively carried on by extensive fishmongers, who have their agents at Brixham and Dartmouth, and sell only in their own shops; none but the coarser description of fish being exposed in a public market. Bristol is, however, generally supplied most abundantly, and at prices, the moderation of which quite surprised me. Salmon may be said to be the only fish for which they depend on Ireland, with occasionally some baskets of soles and turbots from Waterford.

"The fishery regulations of this important district are chiefly embodied in those appended to the Convention with France, confirmed by the Act 6 and 7 Victoria, chap. 79, with this addition, that the $2 \mathrm{~d}$ section of that Act especially saves, and, to a certain degree, amends or explains an Act passed in the 13th and 14th Charles II., chap. 2S, for the especial regulatious of the pilchard fishery in the counties of Devon and Cornwall.

"This last recited Act establishes the principle of a close time, or fence months, from the 1st of June to the last day of November, during which time it is interdicted to take any fish of any kind with any drift-net, trammel, or stream-net, or any other nets of that sort or kind, unless it be at the distance of one league and a half at least from the respective shores. A former statute, 3 James I. chap. 12, and a subsequent one, 2 George 1. chap. 18, contained stringent regulations in reference to the size of meshes of nets, and even the dimensions of the fish which it should be lawful to bring on shore. 
"The more recent Act, 6 and 7 Victoria, sec. 2, confirming the terms of the convention with France, refers only to the Act of Charles II., for the purpose of more clearly defining the distances from shore, outside which trawlers should keep; and all the regulations as to the size of the meshes of nets, with still more minute restrictions as to the length of the poles, the weight of the trawl-irons and chains, \&c., are to be found in the articles of the Convention, from 16 to 26.

"The Convention with France was the result of two parliamentary inquiries : the first in 1817, before a Select Committee on South Devon Fisheries; the next in 1833, before the Select Committee on the Bristol Cliannel Fisheries.

"The Committee of 1817 was appointed at the especial instance of the fishermen of Brixham, and in the proceedings of the second Committee they also took an active part.

"The headlands which form Torbay are Berry Head and Hope's Nose; the distance across about five miles, the depth of the bay about three and a half miles; soundings vary from two to ten fathoms; the tide rises in springs seventeen, and ordinary tides thirteen feet. Captain Storey has found it extremely difficult to enforce the marking regulations. Complaints are sometimes made that the lines and nets of the inshore fishermen are carried away, but believes that trawling within the bay is very rare at any time, but especially during the fence months. There are a few very small boats belonging to Torquay, which sometimes use light beam trawls.

"Lieutenant Hoblyn, R.N., chicf officer of coast-guard, from whom I received every assistance, states, that there are now 221 trawling vessels marked and numbered out 


\section{CHRONOLOGICAL HISTORY OF THE HERRING-FISHERY.}

of the port, ranging from 25 to 45 tons, all cutter rigged. They are called sloops, carvel built, and all exclusively beam trawlers. He describes them as generally well appointed. Each vessel has four men and a boy, or three men and two boys. There are, besides, from 80 to 100 smaller class boats chiefly engaged in the hook and long-line fishing, and, when the herrings appear, in the drift-net fishing; they vary in size from 4 to 15 tous-the smaller class being called yawls. He observes no bad spirit between the two classes; indeed, they are sometimes greatly annoyed by a class of persons called pirates,-strangers who come from distant places and rob their nets at night. All the regulations of the French Convention are generally observed, and the fence months are seldom encroached upon. The trawlers finding that when the weather permits, their most productive ground is far outside the limits, they never trawl in the bay, unless it should be blowing a gale of wind outside, and very rarely during the fence months under any circumstances. They generally trawl in the offing between Start Point and Hope's Nose, about five miles from the entrance to the bay, sometimes in thirty fathoms; but they vary their ground according to the state of the weather. With a strong easterly wind the fish lie off in deep water. It is a mode of fishing particularly liable to casualties. A sloop will sometimes lose her whole gear, to the value of $\mathrm{L} .40$ and upwards. The laws relating to fence months are not well understood, but yet they seldom trawl in the bay; the ground is only fit in the centre, being all foul along shore on both sides. Knows of no instance of a breach of the 25th article of the Convention, requiring trawlers to keep three miles from herring boats. The French boats, from Dieppe and Bourdeaux, often come in during the winter in large numbers. They do not 
attempt to fish within the limits, but purchase skate, which is taken in very large quantities, but no other fish. They are always well received, as good customers for a kind of fish otherwise very unsaleable.

"They object to the regulations of the Convention reyuiring the sails to be marked with oil paint. It rots the canvas in a short time; and the regulation has been modified by the Inspecting Commander permitting the substitution of coal tar, which is quite harmless even in tarpaulins. It is ascertained, that when paid with coal tar, they will last double the time as when Stockholm tar is used.

" Mr Nicholas Smith, President of the Friendly Society of Fishermen, called on me, and stated trawling is the only mode resorted to for the capture of flat fish. They are never taken by spillards or long-lines, which are only used for taking cod and ling:

"There is scarcely ever any trawling in the bay from May to November,-these are what are called fence months; but trawling, even within that time, would not do lialf the mischief that is done by seines hauled on shore, by which thousands of the young of turbot and other fish are taken in places where the travlers could not work. From November they trawl within the bay productively, except when the herrings fall in, in which case they desist. Fish certainly spawn in the shoal water, and on sands protected by rough ground. About November it is usual for a large number of the boats, 30 or 40 , to proceed to Hull, to Ramsgate, or to Tenby. Only the owners of the new and well appointed boats venture on these voyages. When they go, they regularly break up their establishments at home, and take their moveables and families with them, shutting up their houses. The Mount's Bay herring fishers, and those from Worthing, Rye, and Ramsgate, 
come into the bay in spring. Most of the boats belong to wealthy owners on shore, but the crews and masters generally have shares of the vessels. The division of the fish is in the proportions of-

\begin{tabular}{|c|c|c|c|c|}
\hline Owner, & . & - & . & 1 share \\
\hline Vessel, & - & • & . & $1 \%$ \\
\hline Master & . & • & • & 1 \\
\hline Crew, & . & . & . & $\frac{2}{5}$ shares \\
\hline
\end{tabular}

"The vessel's share keeps up the equipment. The provisions are found by owners. The ordinary wear and tear of a boat and gear, without allowing for casualties, may be set down at a L.100 per year, or thereabouts.

"It is the custom for all the boats to come into harbour on Friday afternoon, and to remain till 11 o'clock on Sunday night,- - the Saturday being devoted to repairs and preparations for the following week. The number in on Friday the 15th October, was 120.

"Mr Samuel Saunders, harbour-master, was once a trawler himself.

"There are old laws and regulations about fence months and limits; but they are not much remembered. Lord Vernon, who lived at Churston, ras anxious some time ago, over thirty-five years since, to sce those regulations enforced; but the people did, for a short time, observe them, and have fallen since into the old ways, "governed " only by the common law of the land against doing injury ' one to another, and by the law of God and of conscience; ' Jut their conviction is, the more trawling the more fish. "They see no diminution in the supplies, though the ' number of takers is rlaily increasing. It is like plough' ing the ground,-the small worms are roused up, and 'then come the shoals of fish after them.' 
"On further inquiry I found that this interference of Lord Vernon's, referred to by the harbour-master, had, in 1817, produced the parliamentary inquiry, by a Select Committee on the South Devon Fisheries, at the instance of the great body of fishermen on that coast, by whom a document was signed to the following effect:-

\section{"Brixham-Quay, Torbay, 11th June 1817.}

"We, the undersigned, being persons concerned in 'the fisheries between Start and Exmouth Bay, do ' hereby declare our opinion, that it will materially pro' mote and benefit the said fisheries, if trawls and drag' nets are prohibited being used in Torbay, from 1st May 'to 1st November; in Start Bay, from 1st May to 1st 'October.'

"The recommendation of this Parliamentary Committee, after hearing evidence, was-

" That it will conduce to the benefit both of the public ' and the fishermen themselves, if Start Bay, Torbay, and 'Exmouth Bay, on the southern coast of Devonshire, " are kept free from trawl and shore drag-nets during the "spawning season; and they are the more induced to re" commend some regulations to that effect, as it has been "clearly shown that it will not throw any fishermen out "of employment during those months, and will be the ' means of increasing the quantity of cheap and nutritious 'food, on which all the lower ranks of society in that part ' of the country chiefly subsist.'

"By the evidence taken before that Committee, it appears that there were, at that time, employed in the trawl fishery-

" Four or five hundred men and boys, and about one ' liundred vessels.' 
"The returns of the coast-guard officer, given to me, show the number more than doubled.

"The whole of the Report from which the above extracts have been made, with the evidence upon which it was founded, is deserving of attention, as expressing the unanimous opinion of that day.

"It was ordered to be printed, 20th June 1817.

"The next parliamentary inquiry was in the summer of 1833 , by a 'Committee on the British Channel Fisheries.'

"Thirty witnesses were examined before this Committee.

"The inquiry embraced several very important subjects.

"Before I close, it may be proper to mention, that in addition to the statutes to which I have before referred, as exclusively affecting the fisheries of the coasts of Devon and Cornwall, the whole coast of England and Scotland is included in the statutes for the regulation of the British white herring-fishery, now thirteen in number, commencing with the 4Sth George III. cap. 110, passed into law 1808, and ending with the 14th and 15th Victoria, clapter 26, passed in 1851. I have carefully examined all these Acts, and I find that up to the passing of the 6th and 7th Victoria, chapter 79, passed in 1843 , known by the name of the Convention Act, only one of the statutes passed for the encouragement of the British herring-fisheries contained any restrictive regulation as to engines,-namely, the 48 th George III. cap. 110, section 12 , regulating the sizes of meshes of herring nets; so that the Convention Act, a comparatively recent cnactment, and to the provisions of which Scotland is subject, was the first measure of legislation restraining trawling on the 
English and Scotch coast generally. But after nine years' experience of this Act, the guardians of the British herring-fisheries have, in a special statute, 14th and 15th Victoria, chapter 26, section 6, repeated the restrictions upon trawlers in the vicinity of herring-fisheries when the regular herring-fishery is commenced.

"Although I am desirous to abstain from the expression of any opinion which I may have former on the result of this inquiry, reserving myself for the general discussion of the question before the special Board fixed for Monday next, the 15th inst., I feel bound to wind up with a general summary of conclusions which seem to me fully deducible from the facts which lave been stated in this report:-

"1st, The east coast of Devon, from the mouth of the Exe to Start Point, is remarkable for a productive and most valuable fishing of a mixed kind, as to engines, the trawl net being that most used.

" $2 d$, That the bay or inshore fishing has, for the last 190 years, been, by law, under restraints prescribed by the 13th and 14th Charles II. cap. 28, rendered more stringent by the Convention Act 6th and 7th Victoria, cap. 79 and still further confirmed by the 14 th and 15 th Victoria, cap. 26, section 6 .

" $3 d$, That the restraint prescribed by the Convention Act was the result of, and strongly urged by, the two successive Parliamentary Committees in 1817 and 1833.

" $4 t h$, That a strict observance of these restraints and regulations generally prevails, though there may have been occasional breaches.

" 5 th, That notwithstanding the progressive increase in the numbers of vessels, the supplies of all sorts of fish keep pace with the increased means of capture. 
" $6 t h$, That the last measure of legislation, 14 th and 15 th Victoria, chap. 26, section 6, extending to the whole coasts of Scotland and England, has been enacted at the instance of the Commissioners of British Fisheries, having a large and well-trained staff of officers, watching closely the interests of the most important and most prosperous fishing community in the empire, and that it may be considered an unqualified affirmation of a similar regulation in the French Convention Act, but in more stringent terms, and after nine years' experience of its effects."

We find in the same document a strong attestation as to the injury of such trawling, by the extensive fishmonger, Mr Thomas Anderson, Glasgow, which we think worth reproducing here:-

"Having been extensively engaged in the fish trade in Scotland for the last fifteen years, I have observed, with very much regret, the great injury done to the white fishings by the use of trawl nets. Nearly about ten years ago the trawl net was introduced into the Firth of Forth, and in accordance with the increase of the use of it, the gradual decrease in the take of white fish has been the result. Also on the west coast of Scotland (particularly the Ayrshire coast), it is a well-known fact, that ever since the introduction of the trawl net, there has also been a gradual decrease in the take of white fish; and I am fully convinced in my opinion, that the use of trawl must either destroy the spawn of the fish or the young fry.

"I may also mention, that from one station I had from 700 to 800 young turbot in one day lately, and scarcely a marketable fish amongst the whole, the most of them not weighing more than 1 to $1 \frac{1}{2}$ lbs. These were some of the produce of the trawl; and my objection principally 
applies to inlets, bays, or near the shore. My object being to get as many prime marketable fish as possible, I am of course in no way interested in the prevention of any particular mode of taking fish, which shall not be injurious to the fisheries in general.

"I speak from great experience, I being the owner of large stations in the Island of the Lewis, in the Firth of Forth, the west coast of Scotland, my principal headquarters being in Glasgow; and one way and another employing from 800 to 900 hands."

It will be seen that, apparently in consequence of prohibiting beam-trawling on the Devonshire and Cornwall coast from 1st May to 1st November, the trawlers liave been very successful in the other months.

Beam-Tiazoling, Galway.-The fishermen here having also complained of the destruction of spawn by the boats trawling for flat fish, the Irish Commissioners also prohibited trawling in Galway Bay, when large shoals of herrings or mackerel shall have set in to said bay; and the fishermen are engaged fishing for such fish with drift nets ; and such trawl boats shall, in such cases, keep at least three miles from the boats fishing herring or mackerel.9 th January 1854.

In Belfast Lough trawl nets were also prohibited in 1854 by the Commissioners of Irish Fisheries at all times in that part of the Lough of Belfast comprised within a straight line down from Goay Point in the county of Down, to Kelroot Point in the county of Antrim.

No nets (excepting for taking herrings) are to be used in the said part of the Longh of Belfast under $1 \frac{3}{4}$ inch in the mesh, from knot to knot, under a penalty of 50 s. for each offence, by order of the Commissioners. 
1856.-The fecundity of the herring may generally be supposed to make up for the great quantities fished and destroyed by birds and the finny tribes, yet it is unquestionably a subject of national importance to consider how far the Legislature should farther protect the growth of the herring, and prevent all unnecessary disturbance or destruction of the shoals of herrings, and their fry and spawn. We have stated different causes which may tend to diminish the supply; and it will be seen by the letter, of which we subjoin a copy, from Mr Cleghorn of Wick, a gentleman who has paid particular attention to the subject,* that there may be reasonable grounds for all due care being taken that legislation shall be applied when necessary. We see almost every session of Parliament new Acts as to the salmon-fisheries, which are comparatively of much smaller value than the herring-fishery.

The following is the letter referred to :-

“W Wck, October 7, 1856.

"Sir,-Since you have taken the herrings in hand, allow me to give you some facts that may be of use to you. There is no subject that more requires elucidation.

"In the 'Quarterly Journal of Agriculture' and 'Highland and Agricultural Society's Transactions' for Jume 1839, you will find a good paper on the herring by $\mathrm{Mr}$ Mitchell of Leith. Please turn it up and read it. The herring is much more local than you fancy. The reason why they are found apparently suddenly making their appearance on the shores is, that they just then have matured their milt and roe, and self-preservation is then lost in their anxiety to preserve the race. Then milters

* Addressed to the "Times," and reprinted in the "Scotsman," 14th October 1856. 
and spawners come together. Till now they were bent on individual preservation-each was on his own hook; they aroided nets and other dangers; now all sense of danger is lost,-their only aim is now the preservation of the race; and when in this state sudden destruction comes upon them in a cloud of nets.

"We have on our shores races of herrings that we know come to maturity in July, August, and September. Up to 1851 we took yearly, on an average, 20,000 barrels, but in July 1851 we took 30,000 barrels. This seems to have been their culminating point, for in July 1852 we took only 7618 barrels ; in July 1853, 7829 ; in July $185 \pm$, 2396 ; in July 1855, 2664; and in July 1856, 2977 barrels.

"Our July races, then, are done; we have fished them up; we have all but extinguished them. We are now doing for the August and September races what we have already done for the July ones. Of these, in 1850, we were only able to take 90,000 barrels, although we brought to bear on them $19,000,000$ square yards of netting; the greatest extent of netting ever used here. In 1855 they afforded us 135,000 barrels.

"If the herrings belong to the waters in which they are fished, my conclusion that we are extinguishing the races, or reducing them so low that the produce of the fishery will be less than the outfit, is not so absurd as some would insinuate; but it may be made more apparent when I tell you, that the space over which our boats here fish is from the Pentland Skerries to Clythness, about thirty miles, and seaward about five miles, or 150 square miles. On this portion of sea our 1051 boats every night during the fishing spread $19,000,000$ square yards of netting; or nets 500 miles long. The wonder is, not that we are extinguishing the races, but that they should have lasted so 


\section{CHRONOLOGICAL HISTORY OF THE HERRING-FISHERY.}

long. The netting has been every year expanding; in consequence of the shoals contracting. The poorest districts use. the finest and most extended netting. In 1818, the netting in all Scotland did not exceed 10,000,000 square yards, and with that we took 340,894 barrels, while it appears by the Fishery Report of last year that we employed $80,031,507$ square yards, and caught 766,703 barrels, showing that with eight times the extent of netting we were able only to double the herrings caught.

"The late Mr. Wilson of the Board of Fisheries has settled the character of ground on which the herring spawns,- - see 'Blackwood's Magazine' for April or May last. Were the Government anxious to aid the fisheries, they ought to survey the ocean bottom, and map it out, and let us see at least the portions on which the herring cannot spawn. They never spawn on sand; I believe it must be rough ground. At all events, something must be done. Our summer shoals are now so reduced that we must change our time and the place for fishing; new ground must be sought, longer voyages made, or we must take to winter in place of summer fishing. We must get deep and safe harbours.

"I believe, till the matter be viewed in the light I have done, this fishery is lost. My view is most unpalatable to all engaged in the trade; and they have so long looked on the herrings as being as enduring as the ocean, that my doctrines have been spit upon by them.-I am, your obedient servant, JOHN CLEGHORN."

Were any additional evidence requisite to prove the great advantages of the system of inspection and superintendence by the fishery officers, we would suggest the perusal of a very able pampliet, written at this time hy 
a gentleman of high standing and of great practical experience, who for many years was largely engaged in exporting herrings to the continent of Europe, Walter Biggar, Esq., and who is now retired from business, and has no connection with the Board or the fishery. In this pamphlet Mr Biggar says, "I maintain that it is next to impossible for a man to buy a cargo of herrings entirely upon his own skill and judgment, unless he has been present at the curing and packing of the fish from the commencement. There are rogues in all trades; and it was only the other day that a butcher was fined L.10 by the sitting magistrate in Edinburgh for offering unwholesome meat for sale. If a man will attempt this on a stall in open market, how much easier to escape detection when the unwholesome article is packed in the middle of a cask, and covered with brine and pickle." . . . .

"Though I was upwards of thirty years engaged in the herring trade, and understand it as well as most men, I confess myself unable to buy a cargo of herrings with safety to myself, if the seller be a rogue and determined to cheat me. I should feel myself quite as incapable to do so, as I should be to buy a silver spoon on my orwn judgment, which had not first passed through the Assay Office." *

The early fishing at the Lewis Islands having gradually increased, and as the mode of curing had been also improved, they were eagerly bought at those places on the Continent to which they were sent; and at Stettin, the first arrival in the end of May 1856 sold for L.3, 3s. and L.3, 9s. per barrel; and the arrivals amounting subsequently to 11,883 barrels, the prices declined to L.2 for good qualities, and $24 \mathrm{~s}$. to $30 \mathrm{~s}$. for inferior.

* "A Short Account of the Herring-Fishery in Scotland, by Walter Biggar," page 18. 
The fishing of the herrings on the East Coast was much less than usual ; and while there were 154,962 barrels of herrings imported at Stettin in 1855, the quantity imported there was in 1856 only 99,366 barrels. The prices, however, were high, and ranged from $30 \mathrm{~s}$. to $39 \mathrm{~s}$. per barrel.

In the year 1856, the British Fishery Society, resolving to take immediate steps to improve the harbour of Wick, in consequence of the numerous lives which had been lost at various times from the fishermen being unable to get into the harbour, applied for and obtained an Act of Parliament, authorising them to extend the harbour, and employed Messrs Stevenson, the eminent engineers, to furnish a plan, which was approved of by the Society; but for some reason it was objected to by the Lords of the Admiralty, and the work was not proceeded with, although it was obvious that such a harbour is of great national importance.

In the same year 1856 , one of the inspecting commissioners of the Irish Fisheries, J. Redmond Barry, Esq., before referred to, made a tour on the Scottish coasts, between the 22d August and 13th September, and his evidence as to the system on the said coasts is so extremely interesting, as to justify us in extracting what follows as more immediately connected with the herring-fishery :-

"Having learned at the Office of Fisheries (at Edinburgh) that communications had been received from Dunbar, near the entrance of the Forth, announcing that a prosperous herring-fishery was then going on, and that some complaints had been made of outrages committed on the nets and persons of some Irish fishers, I lost no time in going there, on the 30th August; and to my great surprise and gratification, I found that not less 



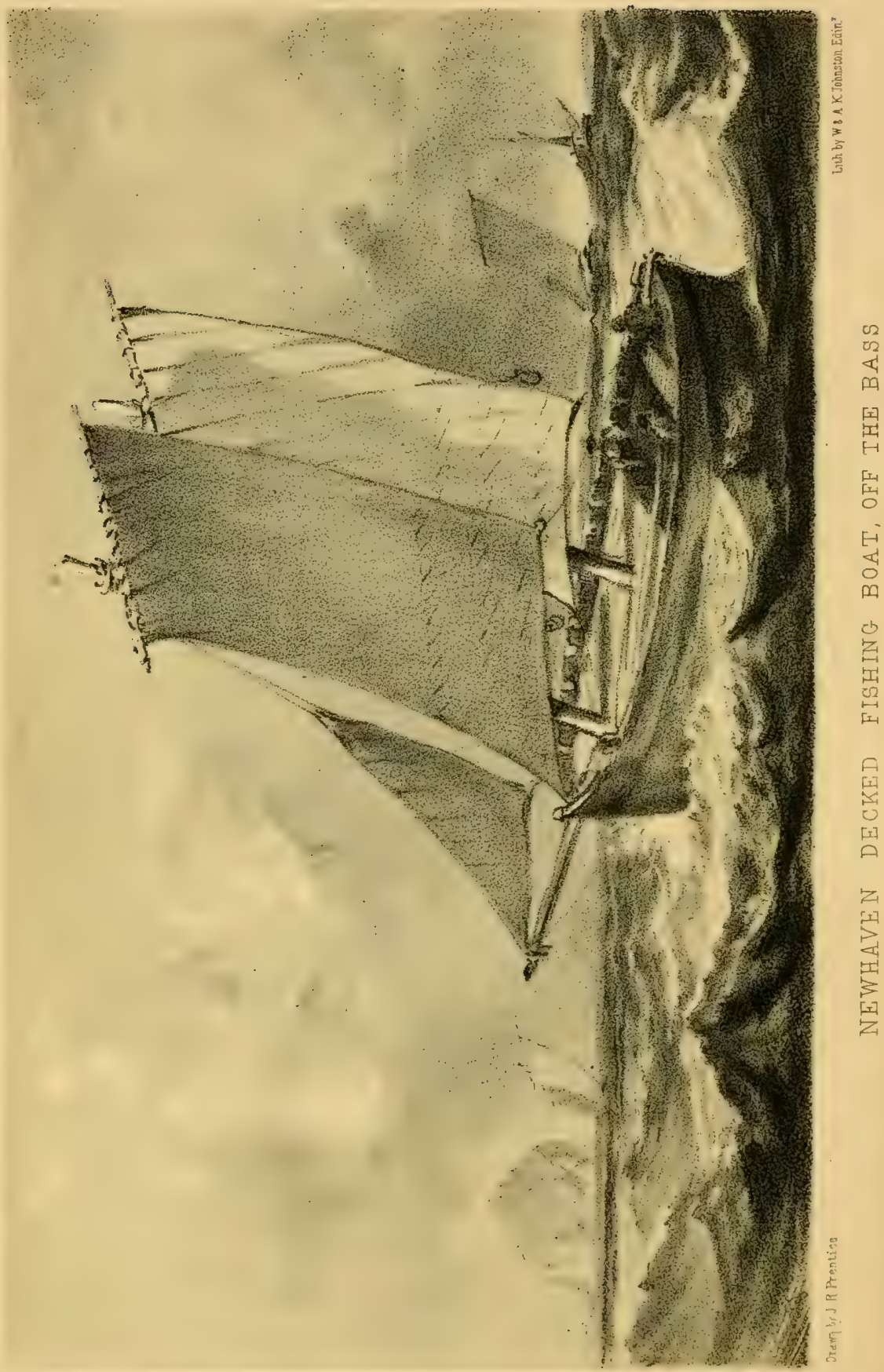


than thirty-two Arklow vessels-viz., twenty-six fishing boats, and six trading purchasing vessels-had exhibited that spirit of enterprise so desirable, by following the herrings to the east coast of Scotland, nothing daunted by the failure of the East of Ireland herring-fishery in the preceding summer. There were also ten Skerries vessels buying and curing in bulk. Some of the Arklow boats had returned home, in consequence of injuries sustained in their nets and buoys, which they attributed chiefly to the fishers from the Fife Coast. They admitted that the Dunbar people were most friendly, and that the authorities of the place had done everything that was possible to afford them protection and redress.

"I could not help deploring the great difference in appearance between the Scotch boats and those of our poor countrymen; the great superiority both in construction and outfit is quite obvious. The best that I saw were the Newhaven boats; and with a view to obtaining information on that very important point, I visited the place. There I saw them of all sizes, completed and at work, as well as in progress in the shipwright's yard. The boats vary in size from 19 to 21 feet keel, about 25 feet aloft, 9 to 10 feet beam, and 4 to 5 feet deep; they are all what is termed clinker-built, and sharp both at stem and stern ; they are light, and plauked with $\frac{1}{2}$-inch larch; the cost of the hull is from L.1S to L.20 ; if copper-fastened, about L.2 more; with materials, they are under L.30. They have two masts and lug sails.

"At Newhaven, where there are about 200 such boats, they are generally hauled up on the beach, when not at sea. It takes ten men to move them up or down. The crews generally consist of four men. The herring-fishery is their great harvest, but they also fish with spilliards 


\section{'298 CHRONOLOGICAL HISTORY OF THE HERRING-FISHERY.}

and long lines; and it is quite cheering to see the Newlaven fishwives at their doors either baiting the hooks or mending nets. The only fixed engines which they use are turbot nets of fine twine, 7 inches from knot to knot, or 14-inch mesh. They are generally seven meshes deep, about 60 fathoms long, with corks at top, and heavy stones fixed by loops about two fathoms asunder.

"Such a thing as a trawling vessel is scarcely known in the Firth. This seems to me to be about the most prosperous fishing corrmunity I have ever seen. In their contiguity to Edinburgh, their orderly habits, great persevering industry, and the indefatigable co-operation of their women, all combined, one can easily find the causes of their success.

"I saw quite enough to impress me with the vast importance, the great maguitude of the herring-fishery on the East Coast of Scotland. It is quite evident that a great deal of excitement and anxiety prevails among persons interested in the trade, on the subject of the proposed abolition of the branding system, and consequent reduction of the Fishery Establishment. The subject being at present under the consideration of a Commission appointer by the Goverument, it would not be becoming in me to venture any opinion upon the expediency of relinquishing altogether the practice of branding; but I should not only fear that the absence of all superintendence would be highly prejudicial to the British fisheries, but would tend to diminish materially the hopes which I have formed of seeing the growing germ of an enterprising spirit on the part of our orvn East Coast fishermen not checked in its bud. Notwithstanding the high standard of moral conduet which I am willing to recognise in our North British neighbours, I should be very unwilling to advise Irish 
fishermen to resort to many parts of the coast of Scotland if the present establishment be extinguished.

"The steady periodical resort of the great shoals of" herrings to the East Coast of Scotland for the last fifteen years, goes far to contradict the general belief in the capricious migratory habits of that fish; but although they keep their ground upon the shores of the North Sea, they frequently vary their position, sometimes abounding on the shores of Caithness, and as far morth as the Orkneys, and sometimes on the shores of Aberdeen, Kincardine, Forfar, Fife, and IIaddington, and as far south as the Tweed. It is an object of great importance to the fishers to be made acquainted speedily with the most favourable localities. Aloug the whole East Coast there are stationed intelligent officers, whose duty it is to communicate constantly with the head quarters at Edinburgh ; and the facilities afforded by telegraph would enable the authorities there to inform us of the movements of the fish. That there is a cordial disposition to afford us every possible aid, I entertain no doubt; and I am sanguine in the hope that the example of last season would, under such circumstances, and with confidence in due protection, induce many adventurers from our shores, notwithstanding the charge of 'indomitable indolence,' to participate in the great harvest of the Scotch herring-fishery, and finally teach them habits which nothing but example and success can produce. Since my return from Scotland, I have learued that the Arklow men having brought home, clear of all expenses, not less than L.8 a man, had resolved upon inaking a similar trial next season, and were already making preparations for improving their boats and gear; but even our poor fishermen can appreciate the alvantages of the existence of a well-organised 
department, whose officers are instructed to do equal justice, and afford to them assistance, arvice, and protection."

On the 16th February 1857, an order was issued prohibiting the use of trawl nets in Belfast Lough, comprised within a straight line drawn from the Castle of Carrickfergus, in the county thereof, to Rockput in the county of Down, and directing that the taking of fish with trawl nets shall not commence in any part of the Lough of Belfast before the 1st April in each year, and shall cease on the 1st December, and the rest of the year no trawl nets to be used.

The herring-fishery of Norway, in 1857, was considerable; and it may be worth while describing the nature of that fishery for the year, it being different, in many respects, from that on our own shores; and we shall take the year 1857, of which we have particulars.

The greatest fishing is in the winter, and the fishermen are suhjected to great dangers and privations; the water is remarkably clear, and the shoals are casily perceived, but generally every season these herrings are pursued or followed by numbers of whales and birds, which, when seen, are a sure indication of the approach of the herrings.

That year the fishery began, 24th January, on the south coast at Skŭdesnæs, and for about eight days there was a very large drift net fishing: There were about 3000 small boats present (manned by three or four fishermen), which each took 15 to 30 barrels daily. Besides this mode of fishing, there is another, which the abrupt nature of the coast, and the absence of tides, give the facility of practising; which does not exist on our coasts,-uamely, "lock fishing." The nets employed in this mode are of great strength and size, and are sometimes 120 to 160 
fathoms in length; they are fastened to the shore, and made to surround a large body of herrings as previously described. This year, one fisherman, with a net of about 150 fathoms in length, surrounded such a large quantity that he sold the whole for 25,000 dollars, about L.5000; but the net was so weak that he was obliged to get a neighbour to place another net outside, to whom he had to give a moiety of the quantity, and had to pay for several vessels or boats to take in the herrings; this took place at Aggerhavn.

The herrings this year were not so large as those of the five previous years. The herrings then fished were about 12 to 13 inches in length, and about the size of Class 4, whereas, in 1857, they were only of the size of Class 5; but the shoals frequently alternate. Sometimes the size is about No. 4, but these are succeeded for a short time by a smaller variety, which are in a short time succeeded again by a larger. The fishery having ended about the fourteenth day off Skŭdesnæs, the boats proceeded farther north to Horegesund, where there was rather an abundant fishing; and thereafter to Espærær, a small island off the coast; and the fishing termiuated at Brandasund, so far as the south fishing goes. Brandasund is about four miles south of Bergen; and this fishery ends about the 20th or 25th February, when the herring shoals on this coast disappear. About 200,000 barrels were taken in this fishery.

The north winter fishery begins about the end of January at Kinœr, which includes a number of islands twentyeight miles north of Bergen, and the fishery lasts to the end of February. The herrings caught are about 13 inches in length, and about Class 4 ; about 1000 boats are engaged in this fishery, and the quantity taken about 180,000 barrels. 
The summer herring-fishery is less considerable; the herrings are about Class 6 to 8 , of superior quality to the winter herrings, and are caught in July and August.

The Norwegian Government has passed important laws lately for the regulation of the fishery; and several vessels belonging to the Royal Navy, each commanded by a naval officer, are appointed to remain on the coast to maintain order, and see that the laws are obeyed, and there are also officers appointed to see that the size of the barrels are of a legal dimension, and that the quality of the herrings are such as they ought to be; and at some of the principal fishing harbours there are stationed several open row boats, under the command of an officer of the Norwegian Royal Navy, constantly moving among the fishing boats to prevent injury to boats or nets by disorderly fishermen.

The dangerous state of the harbour of Wick or Pulteneytown has long excited the attention of all those interested in the safety of the fishermen and the preservation of the herring-fishery; and we fully believe the following remarks on the state of that harbour, which is in near proximity to that which is much more valuable to this nation than all the gold mines in the British dominions:-

Wick Harbour.- "During the approaching herringfishery season we shall have from 1120 to 1150 boats engaged in this perilous enterprise. They will be collected from various districts. Each lawful night 6000 men will leave the shores of Wick on board of these boats, which, with the materials, may be estimated at L.120,000. Spending the night at sea, rowing, and casting and hauling their nets, at distances varying from three to thirty miles, they return in the morning to their respective stations; and when the tide is out, it is no uncommon thing to see 800 boats lying at anchor within an area of 240 acres, with 
their precious freights, all at the mercy of the elements, having not even a narrow sheltered creek to which fifty of them could fly in the event of a storm at low water, or even a couple of hours thereafter."**

In the year 1857, by direction of the Board of Trade, first one set of queries, and then a second set of queries were issued through the British Herring Fishery Board to their officers, as to the appearance of the herring at the various localities, and which we insert:-

QUESTIONS FOR A SERIES OF OBSERVATIONS TO SOLVE TIIE NATURAL HISTORY OF THE HERRING, ORDERED BY THE LORDS OF THE COMMITTEE OF PRIVY COUNCIL FOR TRADE.

It is desirable to ascertain :-

A. Whether the shoals of herrings appear at different localities on the North Atlantic seaboard successively or simultaneously. In the former case, in what order? - whether this order is constant or variable? Whether, in the latter case, the variation can be traced to meteorological conditions? \&c. \&c.

B. Whether there are or are not races of herrings peculiar to special regions of the "herring area" (and there is much reason for believing this to be the case), which merely shift their position from the deep to the shallow part of each region, and vice versa.

C. Whether there are or are not, besides these indigenous races, others which are migratory, either as a regular habit, or in consequence of variations in the food, climate, \&c. of their proper region.

* Northern Ensign, June 1857. 
You are therefore requested to furnish accurate answers to the following questions:-

1. What was the precise date of the first appearance of herring during the present year, and in any other years of which you have accurate record?

2. If there are distinct spring, summer, and winter herring fisheries, state the date of the commencement and ending of each.

3. Do the fishermen distinguish different kinds among the herrings?

4. Do they regard some sorts as native herrings and others as visitors?

5. Are full-grown herrings ever taken in the hauling of nets that may be used in fishing, at times not included in the herring season?

6. Are young herrings taken in this or other modes (as in sprat nets, for instance), throughout the year, or in any part of it besides the herring season?

7. What is the average length of the herring taken on this station? and what is the size of mesh in the nets used?

8. If there are distinct spring, summer, and winter fisheries, is there any marked difference of size and condition between the herrings of each?

9. Send three specimens-ungutted and preserved in strong spirits-of what is considered to be the average herring at your station, stating the precise time at which they were taken.

10. If there are spring, summer, and winter fisheries, send specimens of each fishery, stating the precise time at which they were taken.

11. If any distinction is made between native herrings 
and visitors, send specimens of each, stating the precise time at which they were taken.

Note--It is particularly important to have specimens of the large herring said to be taken in the Shetland and Orkney Isles and also in Loch Fyne.

Board of Fisheries, Edingurgh, January 1857.

ADDITIONAL QUESTIONS IN AID OF THE OBSERVATIONS TO SOLVE THE NATURAL IISTORS OF THE HERRING, ORDERED BY THE LORDS OF THE COMMITTEE OF PRIVY COUNOIL FOR TRADE.

1. Give the date, day, and hour of casting the nets.

2. State where-the distance from the shore, and the direction from the nearest headland.

3. State-The depth of water by sounding fathoms. Length of buoy-rope, _ fathoms. Depth of net, - fathoms. Whether the upper or the lower part of the net was best fished. The nature of the ground where caught-whether gravelly; rocky, sandy, \&c.

4. Give-the direction and force of the wind and the state of the atmosphere; the temperature of the air by thermometer; the temperature of the water at the surface by thermometer; the temperature of the water below by deep-sea thermometer, and at what depth. Any other similar remarks, as for instance-the colour of the water, the clearness of the sea, thunder-clouds, \&c.

5. State the quantity caught; what sort of herrings; the average size.

Board of Fisheries, Fininburgh, January 1857.

These queries illustrate the truth that hitherto very little has been known as to the herring and its habits, 
and we believe that it was found impossible to get such queries answered by fishermen, who had other duties.

1857-8.-In the latter part of the year 1857 and beginning of 1858, the herring-fishery was very successful at Lochbroom; it began alout the middle of October, at Isle Martin, about ten miles above the entrance to the loch, and continued, with tolerable success, until the 17 th November, when the fishing became so abundant that every boat was filled; and there were about 300 boats employed, besides a number of larger boats having small boats employed in fishing and bringing the herrings on board. The shoal of herrings on the 24th November moved higher up to Letters, at the top of the loch, which is about twelve miles above Isle MIartin, and the fishing continued to be successful there until the 16th December. After the 16th December, large shoals appeared again at Isle Martin, which continued until the 29th December. In that neighbourhood the herrings were on this occasion so abundant that some boats got 60 crans in their drift or set of nets by three or four o'clock A.sI. ; and the boats being generally small at this fishing, some of them had to return four or five times to empty their nets left in the water. The size of the herrings was about Class 10, but on the 10th of January 1858, and for a few nights thereafter, some boats caught considerable quantities of the small or native herrings, but this shoal had also a considerable portion of large full herrings, of a size equal to Class 6, or 600 to a barrel. The small herrings disappeared this year, as they generally do, about the begin.. ning of the year, and were succeeded by the large herriugs, which were fished in considerable quantities, until the begimning of February; and on the 6th February, each boat fished about 20 crans. 
At Lochinver and Glendhu the herrings have been also abundant, and fished in considerable quantities about the same time, of a similar size to the kind fished at Lochbroom.

REPORT, 1858, OF DUTCH HERRING-FISHERY 1857.

The herring-fishery in Holland, once so successful, having gradually declined, partly in consequence of the improved quality of the Scottish cured herrings supplanting the Dutch herrings in the continental markets, the Government of Holland wished to take active measures to resuscitate or improve the system in that country, and, in 1857, adopted and copied to a considerable extent the regulations which have been so successfully followed out hy the Fishery Board in Scotland, and which have brought the Scottish IIerring-Fishery to be one of unexampled prosperity. For the first time a Herring-Fishery Board was appointed this year in Holland, and several important laws and regulations were enacted, and, among others, the Crown brand has been introduced, together with various brands or marks expressive of the different qualities, so that everything proves that great efforts will be used to increase a fishery which at one time brought so much wealth into Holland, and laid the foundation of its great industrious prosperity. For the first time also the Commissioners of the Dutch Fishery Board, nine in number, are required, in imitation also of our Fishery Board, to give an annual report of the fishery, and from this document we learn that the Board was installed on the 15 th December 1857.

It appears that the greatest difficulty which attends the Dutch herring-fishery is one which long impeded the Scottish fishery, namely, the salt duties, which now no longer 
exist in Britain. Several rules have been issued by the Dutch authorities on this head, which seem very judicious, as well as those as to the assorting of the herrings, the quality and size of the casks, and the orders to the inspectors, several new ones having been appointed; but everything we see in this Report proves that we owe the great increase of the fishery on our coast to the system of management under a well-regulated Board, and to the care and attention of the fishery-oficers, who have become thoroughly instructed and acquainted with their useful, responsible duties, from the great number of years the various laws and rules have been elaborated by the test of experience.

That some such step was necessary in Holland, is proved from the Report now before us. Not many years since (in 1833) upwards of 300 busses were fitted out from Holland; but now, in 1857, the number employed in the herringfishery was only 90 , namely :-

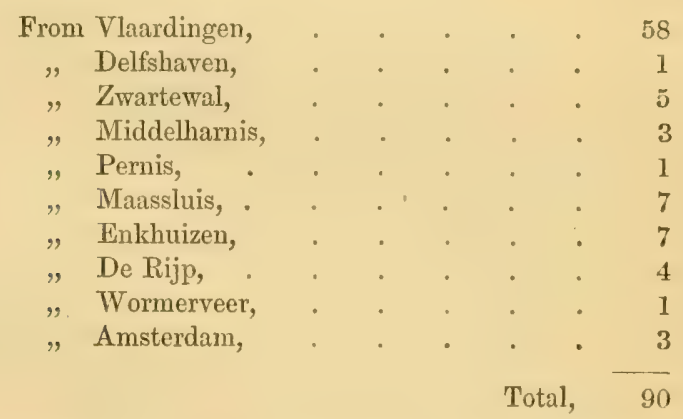

Each manued with 15 men, the total number of the crevs being 1350 ; and even this number of 90 exceeds by 8 the busses fitted out the preceding year ; and, notwithstanding that this number was so small, the result of the fishery was not satisfactory, for the Commissioners report :- 
"Unfortunately, the result of this year's fishery has not come up to the expectations which were formed. The take was less than an average; and it fell, particularly during the yacht time, much lower than in the preceding year. Although three more yachts (jaugers) were fitted out, the quantity brought by them was fully less than half the quantity brought in by the jaugers (yachts) in 1856 . Indeed, the last jauger had to return empty."

The entire quantity caught by the busses was as follows, in the three successive years of-

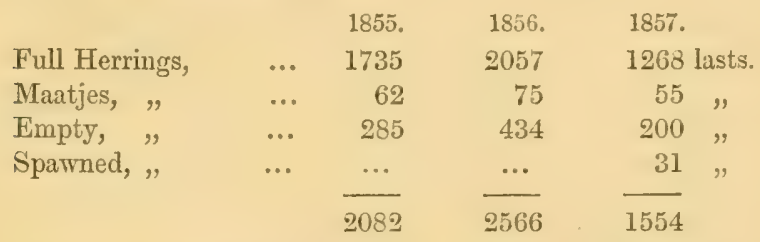

At 14 barrels per last, $29,148 \quad 35,924 \quad 21,756$ barrels.

The loss to the owners from the small take in 1857 was to a great extent made up by the high prices obtained on account of the short supply; the thirty-two lasts of yacht herrings were sold for 46,000 guilders (about L.S per barrel of herrings), while the seventy lasts of 1856 only sold for 59,200 guilders, about L.5 per barrel on an average.

The exportation from Holland during the six fcllowing years was in

$\begin{array}{rrrrrr} & & & \text { Lasts. } & & \text { Barrels. } \\ 1852, & \ldots & \ldots & 975 & \ldots & 13,650 \\ 1853, & \ldots & \ldots & 1111 & \ldots & 15,554 \\ 1854, & \ldots & \ldots & 1254 & \ldots & 16,556 \\ 1855, & \ldots & \ldots & 1173 & \ldots & 16,442 \\ 1856, & \ldots & \ldots & 1447 & \ldots & 20,258 \\ 1857, & \ldots & \ldots & 996 & \ldots & 13,994\end{array}$

The subjoined is a list of the busses fitted out during the ten years from 1848 inclusive, and the number of 
barrels fished and cured, and number of barrels caught on the average by each buss:-

\begin{tabular}{|c|c|c|c|c|c|c|c|}
\hline & & & Dutses. & & $\begin{array}{l}\text { Lants of } \\
\text { 1t burrels. }\end{array}$ & & $\begin{array}{c}\text { Per Buss, } \\
\text { Lants of } \\
\text { 14 Lawerels. }\end{array}$ \\
\hline 1848 & $\ldots$ & $\ldots$ & 107 & .. & 2900 & ... & 17 \\
\hline $1 \leftrightharpoons \pm 5$ & $\ldots$ & ... & 111 & ... & 2260 & ... & 20 \\
\hline 1850 & $\ldots$ & ... & 102 & ... & 1515 & ... & 24 \\
\hline 185̃1, & $\ldots$ & $\ldots$ & 97 & $\ldots$ & 2454 & ... & 25 \\
\hline 1852 , & $\ldots$ & $\ldots$ & 93 & $\ldots$ & 1499 & ... & 1.6 \\
\hline 1853 & $\ldots$ & $\ldots$ & 92 & $\ldots$ & $22=4$ & .. & 25 \\
\hline 1854 & $\ldots$ & $\ldots$ & $: 1$ & $\ldots$ & 2115 & $\ldots$ & 26 \\
\hline 1855 & $\ldots$ & $\ldots$ & 79 & ... & 2082 & $\ldots$ & 26 \\
\hline 1856 & ... & $\ldots$ & 82 & $\ldots$ & 2566 & $\ldots$ & 31 \\
\hline 1857, & $\ldots$ & $\ldots$ & 90 & $\ldots$ & 1556 & $\ldots$ & 17 \\
\hline
\end{tabular}

There are also sereral parts of the coast of Holland where the fishermen take herrings of a small or inferior quality, and also sprats, for the purpose of smoking and pickling. It is remarkable, that in the Zuyder-Zee, in the rear 1857, the fishery of the peculiar quality caught there was much diminislied, and the fishermen sustained great loss to their nets, in consequence of the unnsual number of dog-fish; and the same destructive fish was very abundant and injurious to the fishermen, both on the West Coast and the East Coast of Scotland in the same year.

The fishery in the Zuyder-Zee is called the "pan-fishery," the herriugs are caught late in the year, and in the beginuing of the year: and the report says, that it has been observed that the pan leerings have for some years appeared later than in former jears, which has had some influence on the prices, because the demand is geuerally greatest during the fast weeks of the Poman Catholics.

The quantity brought in of this description of herring to Monnikendam, the head-quarters of this fishery, consisted of only 1198 lasts, of abont 10,000 herrings to the last, against 1539 lasts in the preceding year. The 
quantity brought into Wollenhove consisted of 5835 lasts, and to Enkhuizen, of 3807 lasts.

From Harderwyk were sent out the following quantities in Nethorlands pounds ( 2 lbs. British each) in each of the following years :-

$\begin{array}{cccccc} & & & \begin{array}{c}\text { Inland } \\ \text { Consumption. }\end{array} & & \\ 1855, & \ldots & \ldots & 200,410 & \ldots & \begin{array}{c}\text { Foreign } \\ \text { Consumption. }\end{array} \\ 1856, & \ldots & \ldots & 250,564 & \ldots & 1100 \\ 1857, & \ldots & \ldots & 223,355 & \ldots & 1069\end{array}$

From this quarter forty-one vessels were fitted out, in 1857, to this fishery in the Zuyder-Zee, and there are eight smoking-houses to prepare the red herrings.

The boats fitted out for the fresh-herring fishery, and the quantity and values, are as follows:-

\begin{tabular}{|c|c|c|c|c|}
\hline & Boats. & Herrings. & $\begin{array}{l}\text { Value in } \\
\text { Guilders. }\end{array}$ & $\begin{array}{c}\text { British } \\
\text { Value. }\end{array}$ \\
\hline Scheveningen, & 116 & $22,320,700$ & 350,560 & L. 29,213 \\
\hline Katwyk, . . & 35 & $6,559,850$ & 94,580 & 7,875 \\
\hline Noordwyk, & 6 & 923,000 & 10,973 & 914 \\
\hline & 157 & $29,803,550$ & 456,113 & L. 38,002 \\
\hline
\end{tabular}

Which fishery, although producing $6,400,000$ fewer herrings than in 1856 , yielded about 3000 guilders more money.

In the Report of the Results of the Journals kept lyy forty-five Busses, published by the Meteorological Society of IIolland, 1848, we are told that in June and July the herrings left the east side of the Shetland Islands, and proceeded by two different ways towards the south. They remained in the end of July principally between $56^{\circ}$ and $57^{\circ}$ morth latitude, and proceeded towards the Scottish coasts between $55^{\circ}$ and $56^{\circ} \mathrm{N}$. Lat. in August. In September they began to proceed in a contrary direction 
towards the north, in two wide-spread shoals. In October the herrings had proceeded so far northwards, that they could be taken in greatest abundance between $58^{\circ}$ and $60^{\circ} \mathrm{N}$. Lat.; and in November the herrings were not to be found south of $59^{\circ} \mathrm{N}$. Lat.*

It is impossible in this work to give the particulars of the fishery of each year at the various localities, but it is extremely interesting and very instructive to notice the progress of the fishery at any given locality during a season. For instance, by a tabular view of the fishery at Wick in 1858, we see in the beginning of the fishery the gradual approach of the herrings to the coast, and the gradual increase of the shoal or shoals off Wick,namely, it will be found by the following table that the boats began to try on 10 th July, that no quantity of importance was caught until the 11th and 12th of August, when each boat averaged on the first day 11 crans or barrels, and on the other 22 barrels; that on the succeeding days, until the 28 th of the same month, few were caught, and that the boats only averaged 12 crans on that day; and that thereafter, until the 23d September, no shoals had been discovered, but that on that day only one boat which had gone out fished 17 crans, and the whole average at the conclusion of the fishing was only 85 crans to each boat, whereas in 1855 the average was 142 barrels to each boat.

* Uitkomsten Verkregen uit de Journalen der Harengschepen uitgegeren doer het Kouinklyk Nederlandsch Meteorologisch Institut, p. 8. 
CHRONOLOGICAL HISTORY OF THE HERRING-FISHERY. 313

Daily Take at Wick-Season 1858.

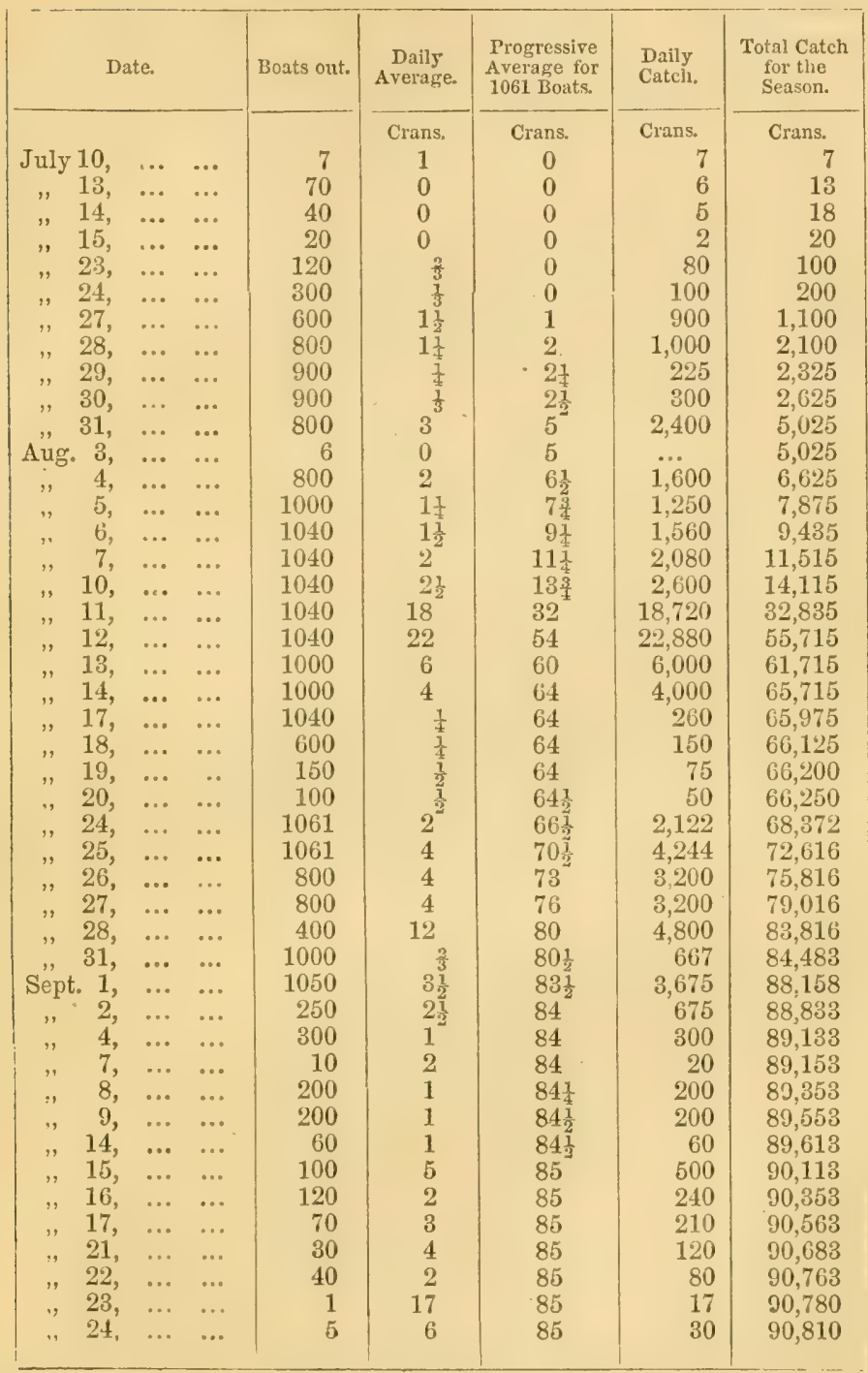

Average for the season-85 crans. 


\section{CHRONOLOGICAL HISTORY OF THE HERRING-FISHERY.}

The short fishing, or the small quantity caught as compared with the fishing of 1855 , does not prove that there were fewer herrings on the coast, but that the shoals may not have been discovered. At Fraserburgh, the same year, the average fishing of each boat was 151 crans, while it was only 90 crans the previous year.

In the year 1856, in consequence of objections by some nembers of the House of Commons to the expenditure in supporting the Fishery Board and the system of superintendence and brauding, and notwithstanding the elaborate and carefully prepared report of the Right Hon. J. G. $\mathrm{S}$. Lefevre on the subject, which went fully into the question, and proved the advantage and propriety of continuing the system, and which we give in a preceding part of this work, a second Commission of Inquiry was appointed, consisting of two English gentlemen, Bonamy Price and Frederick St John, Esq., and an Irish gentleman, Capt. Sullivan, R.N., whose opinions, although expected to be otherwise, did not agree, and the members of the Commission therefore gave in separate reports, the majority in number having reported in favom of the continuance of the brand and of the system. To exhibit the opinions of the different members, we give the following extracts of the report of Messrs Price and St John, a remarkably well written and elaborate report, going over all the arguments for and against the inspection of the officers and the system of branding, which is too extensive to give at length, but the most striking remarks furnished by them are the following:-

"The first argument pleaded by the defenders of the brand, states, we conceive, the real issue to be tried. We have to deal with an established and flourishing trade. It cmploys an immense capital, draws out of the sca a 
large proportion of the revenue of Scotland, and is the chief means of subsistence of a considerable part of the population of that kingdom. Still more, it exhibits those signs of healthy life for which the invigorating impulses of competition are sought and valued. It is progressive. It grapples with formidable rivals, and conquers them. Since 1848, the quantity of herrings imported from Great Britain into the ports of Stettin, Konigsberg, Hamburg and Dantzic, has increased from 100,297 to 318,263 barrels in 1855 ; whilst the Dutch imports into the same places have declined from 5019 to 1300 barrels, and the Norwegian from 194,862 to 122,423 barrels. Is it politic to disturb such an organization? Can an adequate motive be alleged strong enough to call for and justify interference? Is it desirable to destroy, in exchange for another, a machinery which is certainly the concomitant, but which is also represented by a majority of those who carry on the trade to be an efficient instrument of its prosperity? Such we consider to be the practical question to which we are required to give an answer. 1. Now it is essential to observe, that the services performed by the branding are necessary for the herring trade, and must, under any system, be accomplished by some machinery or other. Every part of the work done by the fishery-officers is not only useful but indispensable. Gutters and picklers must he watched, for a few broken or ill-assorted fish would greatly impair the mercantile value of a barrel of herrings. There must be inspection before purchase. That the fishery-officers discharge their duties with admirable judgment, is cheerfully, and even gratefully acknowledged by all parties. ..... Amidst the many attacks made on the brand, there was no accusation that the vast export which it covered ever deceived the confidence of buyers. 
"It cannot be said that the abolition of the brand is demanded by public opinion in Scotland. It encounters the active hostility of some portion of the press; but the opinion of the great majority of the traders is loud in its favour. On the West Coast, which supplies the home markets, and does not use the brand, there is no marked demand for its removal. ..... We are at a loss for a principle on which we could urge the Government to take away from a great trade a convenience which we have shown to be harmless, which will cost the nation nothing, and whose value will be attested by the surest of proofs-the free demand of the traders to purchase it.

"On all these grounds, we have come to the opinion that the abolition of the brand is inexpedient; and we beg to recommend to my Lords its continuance, on condition that it shall be self-supporting:"

Other remarks are made in this report as to ineasures, conventions with foreign powers, police, and trawling, which do not require to be particularly noticed here.

Captain Sullivan, in his separate report, says:-

"1st, As to the effect of the brand on the cure.

"Its advocates assert that it is owing to the brand alone that the present cure has been reached, and that without it the cure will fall off, as it is the iufluence of the officers over all persons employed that keeps up the cure, and not the personal interest of the curer.

"Its opponents, on the contrary, insist that it prevents a still better cure, as it brings down the price of all branded fish to the level of the lowest quality - that is, just good enough for the brand; and they assert that the interest of the curer, and his desire to establish a character for his own brand, must at least have as mucl effect in 
preserving a good cure as any inspection by a gorernment officer.

" $2 d$, The importance of the brand to the curer and buyer.

"Its advocates assert that it gives great facility for carrying on the tracle, and that without it the difficulty of getting the fish into the German market rould be so great, that a serious injury would be done to all connected with the catch, cure, or sale of herrings.

"On the other hand, its opponents allow that it has helped to establish the trade; but they assert that the time has arrived when all Gorernment interference should cease, and the trade allowed to stand on its own merits alone. They also speak with confidence of being able to carry it on without experiencing the difficulties and injuries the other party fears. . . . . The chief value of the brand to the purchaser is, that even without knowing anything of the article he is dealing in, he can, without any trouble or expense, buy parcels of cured herrings, which have been inspected by a government officer, and a certain quality guaranteed by a government brand. Without the brand, he would either have to inspect every parcel he buys, in the same way the officer now inspects them, or, if incompetent to decide on the quality of cure, he would have to employ an agent to do that portion of the work for him."

After various other remarks of a similar kind, he says :-

"Having' given the whole subject, which was entirely new to me, my most serious consideration, I have no hesitation in advising strongly, that instead of attempting to continue the Government interference in this objectionable manner, it should be entirely withdrawn, after sufficient 
notice being given, and the trade left to depend on its own merits alone. I cannot conclude this subject without bearing my estimony to the merits of the officers of the British Fishery as a body. It is lighly creditalle to them, that out of the large number of witnesses examined privately, many of course opposed to the officers, and some ferw annoyed, because at one time or other their fish had been rejected for the brand on what they considered too slight grounds, not one failed to do justice to the strictly honourable conduct of every officer they had met with."

Captain Sullivan also gives his opinions on measures, size of barrels, and the other heads of inquiry.

Considering that these gentlemen had no previous knowledge of this important national fishery, it must be admitted that they seem to have endeavoured to make themselves masters of the important interests involved; but while examining as to facts connected with the brand, they seem to have forgotten-Captain Sullivan particularly-that besides the quality of the fish, the fishery ufficers attend to THE SIZE AND STRENGTH OF THE BARIiELS, ThE EFFICIENCY OF THE SALT AND PICKLE, SIZES OF NETS, the MEASURES FOR FRESH FISH, SEES THAT THEY ARE PROPERLY PACKED, PACKED WITHIN THE PROPER TIME, and VARIOUS other Duties, amounting to at least seventeen branches.

In 1858, the Fishery Commissioners of Ireland seeing the advantage of restricting river trawling, ordered that the following localities on the Irish Coast be subjected to the fence law, pointing out to us the propriety of following such a wise example:-

"Dublin Bay.-Prohibiting trawling inside lines drawn from the Bailey Lighthouse at Mowth to the easternmost point of the rocks called the 'Mugglins;' thence by a 
straight line to the southern point of Dalkey Island; thence by a straight line across Dalkey Sound, in the direction of the signal station on Killiney Hill.

"East Coast.-Prohibiting trawling within a line drawn from the Nose of Howth to the eastern point of St Patrick's Islaud (Skerries); thence to Clogher Head; thence to Dunany Point; thence to Cranfield Point, in the County Down.

"Dundinem Bay, \&ec.-Prohibiting trawling from Hellyhunter Rock, off Cranfield Point, to St Joln's Point, both in the County Down.

"Belfast Lough.—Prohibiting trawling within a straight line drawn from the Castle of Carrickfergus to Rockport, in the County Antrim, and from 1st December to 1st April, and the use of nets of less mesh than one and three-quarter inches from knot to knot (except draft nets for herrings).

"Lough Swilly.-Prohibiting trawling within a line from Knockalla Battery on the west side, to Linsfort Church on the east side of the Lough.

"Donegal Bay.-Prohibiting trawling within a straight line from the Biau Rock to a place called Doorin Point; and from a place called the Blind Rock to the northern point of the Townland of Rossnowlagh, Lower; and from thence to Killdoney Point; and from thence to a place called Pointinchose.

"Galway Bay.-Prohibiting trawling within a line from Barna Pier to Gleninagh Castle. Also when large shoals of herrings shall have set in in the Bay, and while boats are engaged in drifting for herrings or mackerel, and when boats shall commence fishing for herrings or mackerel, that trawl-boats shall keep at a distance of three miles from them.

"Dingle Bay.-Prohibiting trawling within a straight 
line from Bull's Head, near Dingle, to Cununna, near Valentia.

"Bantry Bay.-Prolibiting trawling within a straight line from Cromdy Point to Carrigskye Rock; and from thence to Reeuavanny Point, on the north shore of Whiddy Island.

"Waterford Harbour.-Prohibiting trawling within a line drawn from Creden Head to Temple Church.

"Wexford Coast.-Prohibiting trawling in all places where there are boats engaged in herring or mackerel driftnet fishing; and that trawl boats shall keep at a distance of at least three miles from all boats fishing for herrings or mackerel with drift nets. And whenever herring or mackerel boats shall commence drift-net fishing in any place on or off the coast of Wexford, the trawl boats shall depart therefrom, and keep at least three miles distant from the drift-net herring or mackerel boats."

With the view of lessening the expense to the nation of maintaining the Fishery Board and the officers of inspection, an Act was passed on the 2 d August 1858, the 21 and 22 Vict. cap. 69, requiring that a fee of $4 d$. per barrel and $2 d$. per half-barrel should be paid by the applicants for the brand, when the officers apply it on finding the persons entitled to this test of quality ; the fee to be collected for, and paid over to, the Consolidated Fund.

We find the following account of the state of the fishery at Wick published in the Northern Ensign of 16th December 1858, which exhibits in a striking manner the great progress of the fishery since the year mentioned (1800), at that port:-

\section{"OUR FISHING IN 1800.}

"Through the kindness of a local gentleman, we are 
enabled to lay before our readers a view of the herring fishing in 1800, on which year the total catch was less than 6000 barrels, or about one-fourth of what was caught in one day during the past season. Of the sixteen curers named in the following list only one survives- Mr Donald Bremner. It is also worthy of notice that not a barrel went foreign, and that upwards of a third of the whole catch went off in the shape of red herrings. What a change is now, when 100,000 barrels are an average catch, when the curers number about 120, when red herrings are almost unknown, whon the greater part of our shipments go to the Continent, and when scarcely a barrel is sent to London:"-

- Report to the Honourable the Trustees for Fisheries, \&c., by Willian Macleay, Curemaster of Herrings at Wick, for the year from 1st April 1800 to 1st April 1801.

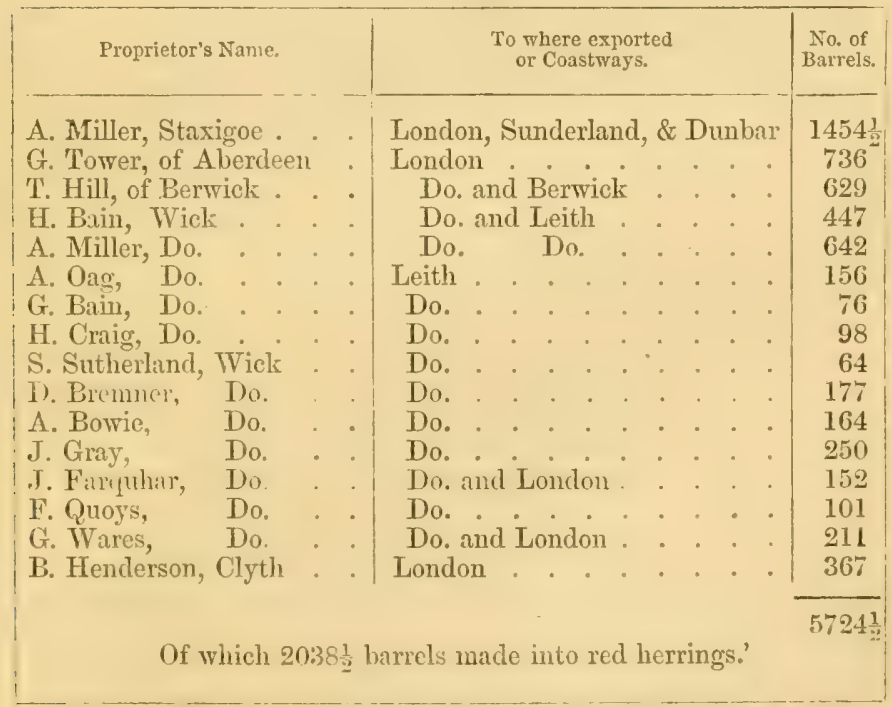


In 1859 a correspondence commenced as to the reduction of the duties in this country and France between the authorities of the two countries, which movement had been promoted by the exertions of Mr Cobden; and in 1860 a treaty was concluded, giving encouragement to the commercial relations of both countries. Seeing that this was a favourable opportunity to obtain an additional market for herrings and other fish in France, we submitted to the Chamber of Commerce and Manufactures of our Scottish Metropolis the propriety of taking advantage of this favourahle opportunity, by cndeavouring to obtain a reduction of the then prohibitory duties in France on herrings and other fish ; and the motion proposed having been unanimously agreed to, a petition was forwarded to the Lords of the Privy Council for Trade, which was favourably entertained; and the following report, presented by us to the Chamber of Commerce, will prove that the exertions we used met with favourable results, considering the strong obstacles raised by some of the influential interests in France:-

liepont on that part of the Tariff under the Commercial Treaty with France applicable to Fish, the produce of this country, in connection with the Memorial from the Chamber of Commerce and Manufactures, addressed to the Lords of the Privy Council for Trade, praying that influence might be used to obtain a Reduction of the Duty on Fish imported into France.

"The Reporter having moved the Chamber to adopt and forward the Memorial on this subject,-which was much strengthened by a petition from the principal merchants and those interested to a similar purport; by the Commis- 
sioners of the British Fisheries, whu sent representations to the proper quarter; and by the inhabitants of Great Yarmouth, \&c., who applied through their representatives to the Govermment,- - he now has respectfully to state that the propriety of using every exertion is the more obvious and urgent, because fish is not specially mentioned in the original treaty, and the necessity for moving to obtain a reduction of the duty on fish is very evident. Scotland produces anumally a large amount in value of herrings (which are now admitted as being equal to the Dutch), cod, ling, tusk, and saith, and are consumed largely in various foreign countries where the duty is not prohibitive The coasts of England also produce large quantities of herrings, cod, ling and mackerel, particularly on the coasts of Norfolk, Cornwall, \&c., all at moderate prices, and in great abundance; but the French duty on importation of fish, the produce of our coasts, has been hitherto quite prohibitory, - the rate exacted is: Fish of the sca, if foreign fishery, dry, salted, or smoked, per 100 kilogrammes, gross weight, 48 francs, which is equal to about 20s. per 112 lb., or on a barrel of herrings about L.3, 10s., and cod fish, per cwt., L.1, which, taking the value of the staple articles of herring and cod, the former at $30 \mathrm{~s}$. per barrel, and the latter at 20s. per cwt., are about 230 per cent. on herrings, and 100 per cent. additional value on cod. These high and prohibitory rates arise from the lesire on the part of the French Government to encourage the fisheries for the purpose of increasing the number of seamen for the navy, and this encouragement has been the means no doubt of greatly increasing the fisheries. I may mention, for instance, that every year there proceed to the cod fishery near Iceland about 350 French large decked vessels; and a great many of smaller 
sized ships fish herrings under a special treaty on our coasts; and about 300 or 400 large ships proceed annually to the cod fisheries of Newfoundland, while the French local fisheries in the Mieditorranean and in the Channel employ a great number of fishermen.

"What may be considered the most important coast or local fisheries of France are those of the-tunny, the herring, and the anchovy. The tunny is taken in considerable quantities by nets in the Mediterranean, on the coasts of Provence, and weighing sometimes as much as $120 \mathrm{lb}$. each. At the fish-market of Marseilles, in September, I found that the tunny was the principal fish consumed. On the coast of Bayonne there is also a considerable fishery of this fish by the line from April to October, one boat taking as many as 150 at a time. It is used fresh, or in oil, and sent to considerable distances for sale. The herring is caught sometimes in large quantities off the French coast in the Channel, in the end of the year. Off the coast of Brittany, the sardine employs about 1200 boats from June to October, and, when it is preserved in oil, is exported in vast quantities from France, and is well known and much esteemed in this country. It will therefore be seen that France is much better supplied with sea fish than is generally supposed. In addition to the supply of fish from the sca, the fishmarkets of France are generally well supplied with freshwater fish; and one of the finest sights in Paris is the admirably constructed and extensive fish-market in that city, where several of the different kinds of fresh-water fish are kept at every stall alive, such as tench, dace, pike, eels, \&c., in pure water, without the slightest offensive odour. The march of civilisation as to fish-markets in Paris is certainly much supcrior to ours in this country. Our 


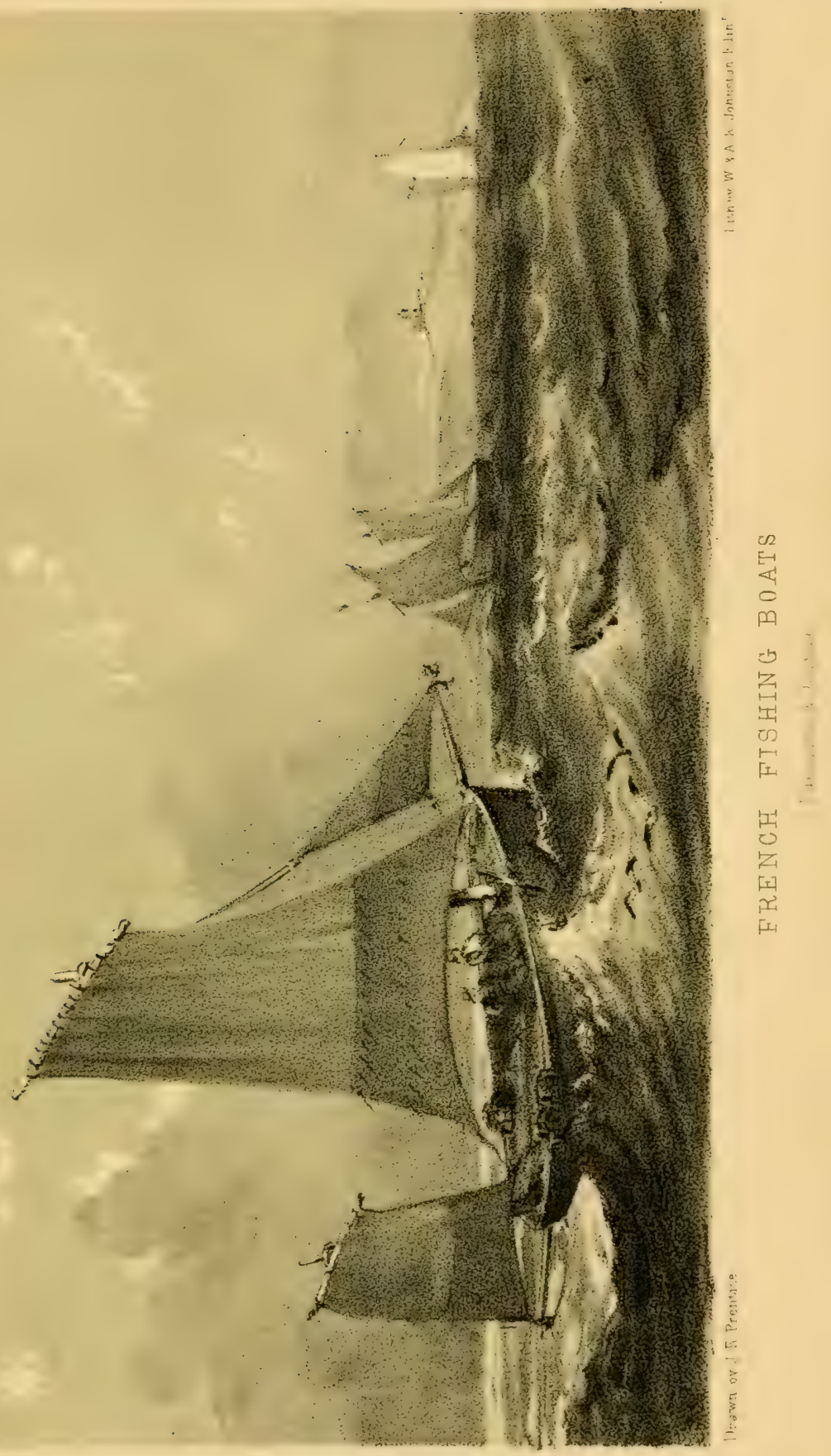



Inarkets often exlibit slovenliness and ignorance on the part of the authorities, and particularly in those of the capitals-Edinburgh, London, and Dublin.

"When at Paris, I represented to Her Majesty's Plenipotentiary, Mr Cobden, and the other two commissioners verbally, the advantages to be gained not only by this country, but by the French, who, particularly the manufacturing population in the large towns in France, would gain by being able, generally at all times, when butchermeat is scarce, to obtain such fish of superior quality as this country can furnish, were the duties of importation reduced.

"As already said, although fish is not specified in the Commercial Treaty, I am favoured with a letter, of which the following is a copy, from Her Miajesty's Plenipotentiary, Mr Colden, by which we are now informed that the duty on the importation of all sea fish has been greatly reduced, with the exception of the duty on cod fish :-

\section{"Paris, 14th November 1860.}

" DEar Sir,-The duty on fish, with the exception of: cod, has been fixed, and will be published with the remainder of the tariff, I expect, in a week or two. This question, as you are aware, involves the consideration of the salt-tax in France, for which there is a slight additiou to be made to the duty on foreign fish. You will find, however, a considerable reduction on the former rate, and I hope it will lead to a tracle to the mutual benefit of both countries.-I remain,' \&c.,

(Signed) “' R. CoBden.'

"The reduction obtained by Mr Cobden is unquestionably considerable. As before stated, the duty litherto has been, on sea fish 48 francs the 100 kilogrammesabout 20s. per cwt.- -and it will now be reduced to about 
4s. per cwt. The French tariff will now, therefore, stand-

"All fresh-water fish (which is stated in the tarill" to include salmon, smelts, shads, and mullets), imported fresh, are free of duty.

"Fresh-water fish, if prepared, 10 francs per 100 kilogrammes.

"Sea-water fish, fresh, salted, dry, or smoked (except cod), 10 francs per 100 kilogrammes, or about $4 \mathrm{~s}$. per ewt.

"As the duty has hitherto been charged on the gross weight in France, if the same system is continued, the imount of duty will be increased about one-fifth on all barrelled fish, which is a very serious addition to the duty. It is to be regretted that cod-fish is excluded from the reduction of duty; but considering the whole question of the duties in France, there can be no doubt that wuch credit is due to Her Majesty's Plenipotentiary, Mr Cobden, in having so far broken down the prolibitory system in that country, and so far begun to prove the propriety and justice of reciprocity between nations, if commerce is to be carried on to mutual benefit. The advantage thus gained by such exertions proves how useful it would be were we to have commercial ambassadors or commissioners resident at every capital of commereial importance in Europe, to watch over and promote British interests. L.7000 or L.8000 expeuded annually in this way, if judiciously employed, might bring great additional wealth to the British nation.-Respectfully submitted by

(Signed) "J. M. Mitcheis."

"On the motion of the Chairman, seconded by Mr Hewat, a cordial vote of thanks was accorded to $\mathrm{Mr}$ 
Mitchell for his exertions in connection with this subject." And in the annual printed Report of the Chamber, dated "January 1861," the above is thus referred to:-

"At Paris, Mr J. M. Mitchell was empowered to represent the Chamber as to that part of the tariff applicablc. to fish, and in the Report communicated to the Chamber. shows the importance to this country of the reduction conceded by the French upon the duties formerly exigible."

As serious complaints were made from time to time that illegal nets were used, particularly on the West Coast of Scotland, at improper times, to take the fry and inferior herrings, an Act was passed on the 13th August 1860, enacting-

"1st, The Commissioners to appoint superintendents of the herring fishery, to exercise all the powers conlerred by previous Acts, except the superintending of the curing and branding; and any person obstructing such officers shall be liable to a penalty of L.50, or imprison. ment not exceeding sixty days.

" $2 d$, Prohibits fishing herrings or fry on the West Coasts of Scotland, hetween the points of Ardnamurehan on the north and the MIull of Galloway on the south, at nny time between the 1st of January and 31st of May inclusive in any year, or between Cape Wrath on the north and the said point of Ardnamurchan on the south. at any time between the 1st of January and 20th of May inclusive; and the Commissioners may, on application, make resolutions and fix the periods during which it shall not be lawful to take or fish horrings within any other limits or locality on the eaasts of sicotland; imy breach of such enactment or such regulations suljects the offender to a penalty of not under L.5 nor exceeding 
L.20, and all nets used shall be liable to be seized and forfeited.

" $3 d$, The Commissioners may from time to time make such regulations as they shall think fit for the more effectual government, management, and protection of the herring fishery on the coasts of Scotland, and for the preservation of order; and any person who commits any hreach in contravention of any such regulation shall be liable to have his boat detained, and to a penalty of L.5, and not exceeding L.20, for every offence.

$4 t h$, The Commissioners may, on application, prolibit on the coasts of Scotland the use of any trawl, drag, or beam net injurious to the spawn of herring or the herring fishery; and any breach of such prohibition will subject the offender to L.5, and not exceeding L.20.

$5 t 7$, The Commissioners may rescind, alter, or amend any regulations wade by the authority of this Act; and all such regulations must be submitted to the Lords of the Treasury for approval, and be duly published by printed copies, and exhilited for two weeks before taking effect.

$6 t h$, Any breach of the provisions of the 6th section of the Act 14 and 15 Vict. cap. 26, shall subject the offender to a penalty not under L.5 and not over L.20, together with forfeiture of the net.

$7 t h$, All boats, sails, buoys, and all other implements of fishing belonging to sinall boats, shall be marked under such regulations as the Commissioners may issue, and, if not so marked, shall be liable to seizure, and may be detained for a period not exceeding one month; and all boats shall have the name of the owner, and the port or place to which she belongs, painted in white or yellow Roman letters, of two inches in length, on a hlack ground, and may be seized and detained for one month if such are awanting. 
Sth, The herring fishery shall be held to be carried on whorever herrings are being caught; and every net other than drift-nets which may be used for the purpose of taking herrings in contravention of the 6 th section of the Act 14 and 15 Vict., cap. 26, shall, during the time of the herring fishery, be removed and laid aside, or shall be liable to be seized and forfeited, and the owner thereof proceeded against accordingly, and such net forfeited and destroyed, and the possessor subjected to the penalty imposed by the existing Acts.

9th, Her Majesty may appoint five additional Commissioners of the Fishery Board liesides the Commissioners appointed under previous Acts.

1860.-The prejudice still manifested by the fishermen generally against beam-trawling lias been strongly expressed, by the Claddagh fishermen at Galway in Ireland, :mong other places, who maintain that the herrings are innually diminishing in Galway Bay, where they were previously abumdant; and (as the quality there is rather above the ordinary description of herrings fished on the Irish coasts), it is very desirable that due inquiry be made, and proper legislation applied. It is of much importance that we should ascertain the advantages obtained, and the injury done, by beam-trawling: If it can be established that the process of such trawling breaks or scares away the herring shoals, and if the beam-trawls fall on, and disperse and destroy the deposited spawn or young herring or fry, the trawling ought to be prolibited at such places and periods when the injury occurs. 'I'o show to what extent the trawling is believed to be injurious by the fishermen in Ireland, we here give extracts of the reports of the Commissioners of Fisherics for Ireland for 1860 , hy which it appears that the spirit of resistance has 
gone so far at Galway as to occasion serious cases of breaches of the peace and destruction of property, while part of the report of the Inspector elucidates the advantage of local fishery officors to instruct, and to prevent riots and disorder among the fishermen.

The inspecting Commissioners say-"From Galway Bay we have had during the past year applications from the Claddagh fishermen to extend the line more westward, within which the use of the trawl-net should be prohibited."

"Patient and lengthened public inquiries were held for three days. The demand made by the Claddagh fishermen extended to the prohibition of trawling about eight wiles beyond Blackhead, which, if complied with, would have the practical effect of preventing this mode of fishing inside the Arran Islands, as it would cut out the greater part of the trawling ground, and leave too limited an extent of ground for any extensive operatious to be carried on by this mode of fishing.

"The only persons who appeared on the inquiry were the applicants for the restriction, the Claddagh men, who are now opposed to this mode of fishing, though in 1852 and 1853 they adopted it with but few exceptions. The evidence being to a certain extent ex parte, the Board lecided that before any steps should be taken to prohibit a most productive mode of fishing, such as trawling is, the most unequivocal practical proofs should be afforded of its decided injurious effects on the fishery of the bay, and have therefore ordered a practical investigation of the subject, which will take place as early as possible.

"We are sorry to be obliged to mention that contentions of a serious nature have arisen between the two classes of fishermen in Galway Bay, and that one of the trawl boats was set fire to, but whether by any person connected with 
those who would wish to sce trawling abolished, of course we cannot say. His Excellency the Lord Lieutenant considered it right to offer a reward for the conviction of the perpetrators of the outrage. We refer to Mr Brady's report on this subject."

The inspector, Mr Brady, enters more fully into particulars, and we think his remarks as to the state of matters at Galway worth recording:-

\section{ON TRATLING IN GALWAY BAY.}

"A very great amount of excitement prevails amongset the Claddagh people, in reference to this mode of fishing, which they say is not only injurious, but has destroyed the fisheries of the bay. Whatever be the cause, I believe, from the evidence I received, both in the Courthouse and in the Claddagh, that these people are in i sad state of destitution. The Claddagh people, I am informed, number at present over 3000 souls, depending exclusively on fishing, and having no other mode of livelihood; and therefore I submit, that it is an important matter, not only for the peace of the country, but for the benefit of the fisheries, that the Board should be in possession of some facts conceruing this mole of fishing; which cannot possibly be ascertained at public meetings. The disputes in reference to trawling in Galway Bay are going on now since 1839, when it was then urged that all trawling should be prohibited inside a line drawn from Blacklicad to Spiddle. And on the late investigations the Boart will observe, on reference to the evilenee, a new feature presented itself, viz., that the greatest yuantity of unsizeable fish, and the brood of fish, is taken hetween a line drawn from a place called Ballyrean, 
about five or six miles outside Blackhead, to Tully Castle on the north, and the two points Blackhead and Spiddle, or about five or six miles outside the line originally proposed in 1839 ; and that the greatest injury was done by the trawlers on this ground. It would appear as if a belt of sand lay across the bay in this place, on which the young fish rest. No evidence was produced, on the part of the trawlers, to show whether this was the case or not, as they did not appear in Court; because, as was mentioned, that their presence might raise the passions of the Cladilagh people to such a pitch that they could not be restrained, and that a breach of the peace would ensue. This was sworn to by declarations handed in by the professional men employed on the part of the trawlers. This fear I believe not to be exaggerated, notwithstanding the evidence which had been produced to prove the good conduct of the Claddagh people, and their general observance of the laws. The consequence of this intimilation is, that the Board have only a one-sided testimony on which to judge. It is but justice, however, to state, that although a great excitement prevailed, the Claddagh people, who mustered in great numbers in the Courthouse, behaved orderly and peaceably ; and several magistrates came forward to give evidence as to their general good conduct and observance of the laws. Amongst the rest, the resident magistrate stated he had not known an instance of impropriety amongst them. In 1839, so much excitement prevailed on this subject, that it was judged expedient by His Excellency the Lord-Lientenant to have a war-vessel to protect people employed in trawling on this coast and that of the county Donegal; and soon after the passing of the 5th and 6th Vict., cap. 106, in 1842, the Board, after inquiry, made a by-law prolibiting 
trawling within a line from Barna Pier on the north, to Gleninagh Castle on the south. The people became a little tranquillised after this, though they still urged a greater extension of the line; until 1852, when further breaches of the law occurred, and such threats were held out, to destroy all the trawlers in the bay, that it was judged expedient again to have a war-vessel to protect those who were pursuing their lawful avocations. At that time the Board held further investigations into the matter, to ascertain whether a greater restriction should be put on trawling; and in 1854 the Board caused certain by-laws to be made, prolibiting trawling; when shoals of herrings had set in, and while boats were at such times engaged in drift-net fishing; and prohibiting trawl boats coming within three miles of herring boats. It appears these by-laws have been a dead letter, as it is alleged they could not be carried into effect, from the fact that herring boats only fish at uight; and it would be impossible to ascertain whether trawl boats were within three miles or not of herring boats. After the inquiry in 1852 , nearly all the Claddagh fishermen adopted trawling, but practised it only for a short time (about a year, or a year and a-half), and then abandoned it, although, I believe, from the inquiries I made, they made money by it; but the fact is, their small boats were not able to compete with the large trawlers cmployed by private enterprise; and the people were full of prejudices and improvident, and when their trawl nets were woru out, they had no means of buying others.

"The Claddagh men are a very peculiar race of people, living exclusively amongst themselves, depending solely on fishing for their livelihood, and are full of prejudices. Amongst the many, they will not allow any boat to go 
out for herrings before the whole fleet is realy; and the consequence is, that although there may be a shoal of herrings in the bay, no crew, however enterprising, dare venture out until it pleases the Lords of the Claddagh to say the fleet is ready. In last August, when I was at Galway, I heard that a boat's crew, more daring than the rest, had ventured out one night before the fleet, and caught a good many herrings, and when the boat came in, the people on shore attacked the boat, and destroyed both it and the nets. This was authenticated by the sworn testimony of one of the Claddagh men themselves at the late investigation. It is only by a quiet, resolute determination, and pointing out their crror, that these prejudices will be overcome, and this I have experienced from the few interviews I have had with them; and I helieve, that if they were taken in hands determinedly, and the man of enterprise amongst them protected and supported, eventually their prejudices might be conquered, and the navy well supplied out of their ranks by fine hardy seamen."

We have no doubt, from careful observation, not only at Galway but also in other quarters, that beam trawling is injurious to the leerring shoals, and may diminish, or ntterly destroy, the annual visits, as they are easily scared away. For instance, so soon as a herring shoal spawns, thither the various kinds of flat fish assemble, and the beam trawls following, these tear up and annihilate the spawn in large quantities, and the herrings may cease to return.

As it was found that there were considerable facilities on the West Coast to enable the contraveners of the law to dispose of the herrings or fry during close-time, a new Act was passed on the 1st August 1861, the 24th and 25th Victoria, c. 72, enacting- 
"1st, That whoever has in his possession, or sells, or offers to sell, herrings or herring fry, known to have been taken on the said West Coast of Scotland during close-time, shall be liable to a penalty of not less than L5, and not exceeding L.20, for every offence, besides the forfeiture of such herrings and herring fry, and of any boat, box, or package in which they may be found.

" $2 d$, Any person defacing, altering, or in any way endeavouring to conceal the marks or numbers enacted by law, on any boat, sail, herring net, or other implements, shall be liable to a penalty of not less than L.2, and not exceeding L.10.

" $3 d$, The Commissioners of the British White Herring Fishery may, by regulations to be made by them, suspend the operations of this and the preceding Acts, within such part of the Firth of Forth as is situate to the westward of a straight line drawn across the Forth, from the west pier of South Queensferry on the south side, through Bimer Beacon, to the shore on the north side, to such extent and for such period as they shall judge fit, so as to admit of the sprat fishing."

Having thought it might be interesting to keep a journal of the progress of the winter herring fishery on the Firth of Forth, we took notes of the results of the fishing as far as could be ascertained; and although not so perfect as might be wished, the following may serve the purpose proposed, to prove the peculiar nature of the winter fishing of 1861-62:-

Journal of the Winter Herring Fishery in the Forth, 1861-62.

1861.

Oct. 28. First boat went out to try for herrings, and came in from off Granton with 700 herrings, Another from Inchkeith, with only one or two herrings. 
1861.

Oct. 29. Three boats from off Granton, about 100 or 200 herrings each. Examined twelve of these, viz. :-

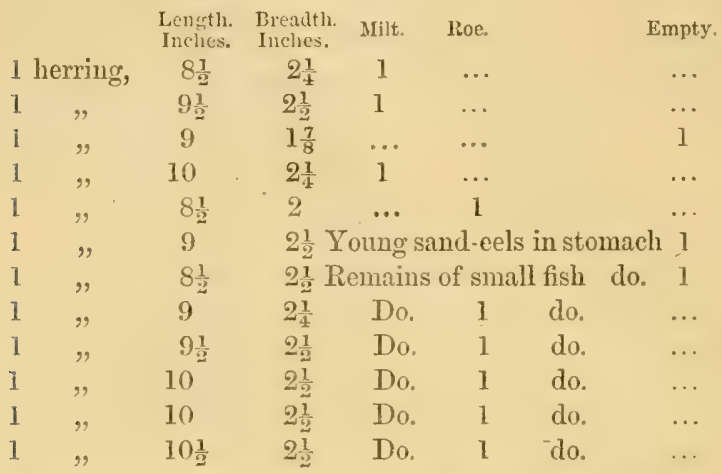

.. 30. Four boats went out for herrings, each got 600 or thereby ; and other boats tried for sprats near Granton, and above the Queensferry, and got few or none.

. 31. Seven boats tried for herrings off' Burntisland; only got a few ; other boats tried for sprats, but got none.

Nov. 1. Stormy, -no boats out.

. $\quad 2$. Some boats tried for herrings enst of Inchkeith, and got six to eight hundred very superior herrings, much finer than those from ofi Granton. Examined six of these :-

\begin{tabular}{|c|c|c|c|c|c|c|}
\hline & $\begin{array}{l}\text { Length. } \\
\text { Inches. }\end{array}$ & $\begin{array}{l}\text { Breadth. } \\
\text { Inches. }\end{array}$ & $\begin{array}{l}\text { Thickness } \\
\text { Inches. }\end{array}$ & Miit. & Line. & Empty. \\
\hline 1 herring, & 9 & $2 \frac{1}{3}$ & 1 & ... & 1 & $\ldots$ \\
\hline $1 \quad$ & $9 \frac{1}{3}$ & $2 \frac{1}{2}$ & 1 & 1 & $\ldots$ & $\ldots$ \\
\hline " & $9_{2}^{\mathrm{Z}}$ & $2 \frac{1}{2}$ & $1 \frac{1}{8}$ & 1 & & $\cdots$ \\
\hline " & 9 & $2 \frac{3}{4}$ & 1 & $\cdots$ & 1 & $\begin{array}{l}\text { In stomach, young } \\
\text { fish, } 2 \text { to } 2 \frac{\pi}{2} \text { in. } \\
\text { in length. }\end{array}$ \\
\hline " & $9 \frac{1}{2}$ & $2 \frac{1}{2}$ & $1 \frac{1}{8}$ & 1 & ... & Do. young fish. \\
\hline, & $10 \frac{1}{4}$ & $2 \frac{3}{4}$ & $1 \frac{1}{4}$ & 1 & $\ldots$ & Do. do. \\
\hline
\end{tabular}

"4. A boat tried for sprats above Queensferry, and got about six barrels.

.. 6. One boat tried above Queensferry, and got about six baskets sprats. Some boats tried for herrings off Granton, and got from 600 to 1500 herrings.

.. 7. About thirty boats at the herrings off Granton, got from 600 to 3800 large herrings. Examined six of these, viz. :- 
CHRONOIOGICAL IISTORY OF THE HERRING-FISHERY. 337

1861.

\begin{tabular}{|c|c|c|c|c|c|}
\hline & $\begin{array}{l}\text { Length. } \\
\text { Inches. }\end{array}$ & $\begin{array}{l}\text { Breadth. } \\
\text { Inches. }\end{array}$ & Milt. & Roe. & \\
\hline 1 herring, & 9 & 2 & $\ldots$ & 1 small & \\
\hline 1, & $8 \frac{1}{2}$ & 2 & $\ldots$ & 1 small & Small debris \\
\hline ", & $9 \frac{1}{2}$ & $2 \frac{1}{4}$ & 1 small & $\ldots$ & of fish in \\
\hline 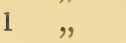 & $10 \frac{1}{2}$ & $2 \frac{1}{2}$ & $\ldots$ & 1 small & these five. \\
\hline " & $9 \frac{1}{2}$ & $2 \frac{1}{4}$ & $\ldots$ & 1 small & \\
\hline , & 10 & 2 & 1 small & $\ldots$ & \\
\hline
\end{tabular}

Nur. 9. Boats tried for sprats near Burntisland and above Queensferry, and only got a few dozen each. Several boats tried herrings off Granton, and got 500 to 600 herrings each. Examined six of these, viz. :-

$\begin{array}{lcccc} & \begin{array}{c}\text { Length. } \\ \text { Inches. }\end{array} & \begin{array}{c}\text { Breadth. } \\ \text { Inches. }\end{array} & \text { Milt. } & \text { Roe. } \\ 1 \text { herring, } & 9 & 1 \frac{7}{8} & 1 & \ldots \\ 1 \quad, & 9 & 2 & \ldots & 1 \\ 1 \quad, & 10 \frac{1}{2} & 2 \frac{1}{2} & 1 & \ldots \\ 1 \quad \% & 10 & 2 \frac{1}{4} & \ldots & 1 \\ 1 \quad \% & 10 & 2 & 1 & \ldots \\ 1 & 9 & 1 \frac{7}{8} & \ldots & 1 \text { small. }\end{array}$

11. Very stormy from the east yesterday. Boats went out about five this morning. Only a few herrings in each boat.

12. Several herring boats out, and brought from 500 to 3000 herrings fished in the middle of the Forth. One boat first tried off' Burntisland, and got 150 ; then the middle of the Forth, 50 ; and afterwards near St David's, and got 2000 herrings.

14 to 23 . Stormy weather. Thirty boats with sprats-average, 20 barrels per boat. Boats, when weather permitted, fished herrings off Burntisland and above Queensferry ; from 700 to 3000 herrings. Sprats, in about thirty boats, 20 crans on an average; no small herrings, but a few Matje herrings among them.

24. Sunday.

25. Stormy. No boats out.

26 to 30 . Boats got 800 to 1500 herrings. About thirty sprat boats out ; they got 20 to 30 barrels each ; sold at from 8 s. to 12s. per barrel; but weather stormy for several days, and no boats out for herrings.

Dec. 6, 7. Stormy. Herring boats got 2000 to 3000 herrings off Buckhaven and off Burntisland. Sprats abundant, and selling at 2s. $6 \mathrm{~d}$. to $3 \mathrm{~s}$. per barrel; herring at $5 \mathrm{~s}$. per hundred.

8, 9. Herring boats got 2000 to 3000 herrings. Six or seven boats of sprats, about 30 barrels each. Thirty-five herring boats oft Burntisland got from $2 \frac{1}{2}$ to $8 \frac{1}{2}$ crans each; sold at $22 \mathrm{~s}$. per cran. 
1861.

Dec. 10. Sixty boats full of sprats, mixed with full-sized herrings. About ten boats got herrings near Inchkeith, large, full herrings,about 2000 each.

11, 12. Stomy, no herring boats out; but boats with full cargoes of sprats-some large, and also young, herrings among them.

13, 14. Boats with herrings, five or six crans off Newhaven; off North Berwick, 200 to 400 herrings; Burntisland, and above Inchcolm, 2000 to 5000 herrings each.

16, 17, and 18. Opened a COD-in stomach two full-sized flounders, two lobsters about 12 inches-a CoDLING, four small crabs, four prawns, \&c., in stomach. Herrings from Inchkeith, each boat eight crans. Sprats left ground above the Ferry,fishermen say caused by spring-tides; they are now below Ferry.

19. Opened a corl 3 feet in length,--two full-sized herrings, three young gurnards about 8 inches, and some debris, no sprats, in stomach.

21, 21. Boats from east of Inchkeith, 2000 to 4000 herrings ; a few boats with sprats and small herrings.

23, Mondaty. Herring-boats fished west of Granton, and got 2000 to 4000 herrings each. 1862.

Jan. 7. Sprats scarce west of Queensferry. Some boats got ten to twelve barrels east of Queensferry. Full-sized herrings fished near Inchkeith (east of it), about four or five crans up to the end of last month. These three or four days the boats fishing from the Queensferry down to Leith Pier (seen from shore), and got from four to six crans. Examined eight herrings fished to-day :-

$\begin{array}{cccc}\begin{array}{c}\text { Length. } \\ \text { Inches. }\end{array} & \begin{array}{c}\text { Breadth. } \\ \text { Inches. }\end{array} & \text { Milt. } & \text { Roc. } \\ 12 & 2 \frac{1}{4} & 0 & 1 \\ 11 \frac{1}{2} & 2 \frac{1}{2} & 0 & 1 \\ 9 \frac{1}{2} & 2 & 0 & 1 \\ 10 & 2 \frac{1}{4} & 1 & 0 \\ 10 & 2 & 1 & 0 \\ 9 \frac{1}{2} & 2 & 0 & 1 \\ 9 \frac{1}{4} & 2 & 0 & 1 \\ 9 & 2 & 0 & 1\end{array}$

Examined 1 HADDOCK, about 18 inches-in stomach, whole and broken shells and some debris; also a copling about 15 inches-two small crabs and small pieces of fishes.

9. Boats at sprats below Ferry; several taken possession of by 
1862.

revenue cutter. Boats at herrings, various success ; from two to twenty crans, full size. Best quality and largest quantities near Inchkeith.

.Tan. 31. Latter part of month, boats fished near Island of May. Seventy boats fishing one day off Anstruther; highest, fifteen crans.

Feb. 4. Westerly and changeable ; no appearance of spawning yet.

7. Some boats returned, left the fishing; few herrings seen or got. Strong wind, N.E. Herrings fished at various places on the East Coast-six to eight crans each boat.

Mar. 1. Herrings fished off' Anstruther. Eximined six of these, viz. :-

\begin{tabular}{ccl|ccl} 
Length. & $\begin{array}{c}\text { Breadtl. } \\
\text { Inches. } \\
\text { Inches. }\end{array}$ & $\begin{array}{c}\text { Length. } \\
\text { Inches. }\end{array}$ & $\begin{array}{c}\text { Breadth. } \\
\text { Inches. }\end{array}$ \\
$10 \frac{1}{2}$ & $2 \frac{1}{4}$ & milt. & 11 & $2 \frac{1}{2}$ & roe. \\
$11 \frac{1}{2}$ & $2 \frac{1}{4}$ & roe. & $11 \frac{1}{2}$ & $2 \frac{1}{2}$ & milt. \\
11 & $2 \frac{1}{4}$ & roe. & 11 & $2 \frac{1}{4}$ & empty.
\end{tabular}

Success various until the

6. Some boats fished about twenty crans near May Island, and a good appearance. One boat had thirty-five crans at Dunbar, but quality of herrings indifferent; many spawning, lank and sickly. Many boats came into Anstruther with fifteen to twenty crans; fishing near the May Island, one boat, forty-five crans; sold at $45 \mathrm{~s}$. per cran. About 300 boats fishing; but soon after the herrings left, and the fishing ceased.

1861. - The fishery off the coast and near Dunbar was very abundant this year, and yielded several thousand barrels, the great proportion of which was sold fresh, of which no account was obtainable. About the 30 th of August the shoals began to deposit their spawn a short distance from the harbour, and on the 31 of September the fishermen found that a very large body of herrings remained fixed to the ground in the progress of spawning, the ground being of a rocky or stony nature. When the fishermen ascertained this, several of the boats proceeded to the spawning ground, and, letting their nets down to the bottom, took up large quantities of herrings, some of the hoats having each about sixty crans or barrels of herrings. When discharging their eargoes, the boats and nets were 
covered with the ripened and expelled spawn. 'The fishermen most unwarrantably continued to fish the herrings in this state even during the day, thus disturbing the fish on their spawning ground, on Sunday the 1st of September and two following days, - the Sunday having all the appearance of a week day, with the landing, selling, and carting the herrings. This disturbance of the spawning shoal was most injudicious, and the more to be condemned when it is considered that the fishermen had just about finished a most successful scason. The ground on which the herrings deposited their spawn is about half a mile from the shore, and about three quarters of a mile in length, and a quarter of a mile in breadth. It was easily known from the sea having a whitish opaque appearance, and from the strong fishy or oily odour. Immediately after spawning the herring shoal started off, and for the space of three weeks the ground was swarming with whitings, cod, and other fish, which were evidently attracted by the spawn; and these afforded an abundant fishing to the Dunbar fishermen for the two or three weeks after the depositing of the spawn. In about three weeks the spawn had been evolved, and the young fry left when the fishing of the whiting, cod, \&c. ceased. ${ }^{1}$

1 On Saturday, the 31st of $\Lambda$ ugust, the Fifeshire fishermen, in their boats, were moored at the mouth of Dunbar harbour, and refused to allow the Newhaven fishermen or their boats to get out of the harbour, when some of the Newhaven men cut the ropes of the Fife boats, and a number of the men of the latter came on shore to punish the aggressors. Then a challenge took place, whon the respective crews of each party proceeded to the Green, and there was a regular pitched battle, which lasted for some time; but ultimately the Fife men were defeated, and retreated to their boats and left the harbour, leaving the Newhaven men masters of the field, or rather harbour, with free power of egress. We give this short notice of the battle, as it is remarkable on account of the unusual occurrence of such a contest among our fishermen. 


\section{DIVING FOR SPAWN.}

1862. - As it was considered of material importance by the Honourable the Commissioners of the Fishery Board to ascertain the circumstances connected with the depositation of the spawn of the herring, the cutter "Princess Royal" was appointed to proceed to the localities where the herrings were supposed to deposit their spawn, in the spring or beginning of the year of 1862 , and men accustomed to use the diving apparatus were employed to go down to the bottom of the sea to examine the grounds, and to bring up such spawn as might be discovered by them; and the following is a short account given by them of their operations :-

The divers went down to the bottom of the Fluke Hole, off St Monance, where the deptlı of water was from 13 to 15 fathoms, and found that the bottom consisted of coarse sand and small stones, but they found no spawn.

Various other places were examined, namely, near Gullan Ness, in about 8 to 9 fathoms, where the ground was sand and shells; between Mickery Island and Charleston, from 7 to 10 fathoms; and again, on the 29 th, at the Fluke Hole; but still no spawn was found.

The divers having been told that spent herrings had been lately taken near the May, they went down in the beginning of March to the west of the May, in 15 fathoms of water, where they found spawn firmly attached to the stones, and they sent up a considerable number of such stones, of from 3 to $16 \mathrm{lb}$. weight, with the spawn fixed upon them; the bottom there was found to be stones, shells, sand, and shingle.

On the east of the May, a considerable quantity was found in 20 fathoms water, adhering to coarse shelly sand; 
the deposit was about three-fourths of an inch thick, and was attached to a cake of the rough shells and sard.

The divers thereafter proceeded to search under water for spawn between Craig Leith and North Berwick in 9 fathoms water, the ground being rough shelly sand, and also again in the Fluke Hole, but found no appearance of spawn.

Various other places were tried at various times, and no spawn found, excepting in the places already mentioned; and three weeks after the spawn was first discovered to have been deposited, the ground where the spawn had been found was examined, and it was then without any spawn.

The divers say that they several times saw, when looking up, or around them, fishes of the size of herrings moving about, but they could not see them so distinctly as to be able to assert that they were herrings.

An intelligent member of the Royal Physical Society having obtained some of the spawn which had been dredged up, put it into glass-bottles, or cans, with salt water, and exhibited them alive at a meeting of said Society; nothing in the form or appearance of these minute fishes could warrant the assertion that they were undoubtedly young herrings, although there is every probability that they were. Several other gentlemen tried to breed the young which had escaped alive from the spawn, but none lived in the aquarium longer than four weeks. Attempts were also made to breed them by placing the spawn in boxes or cans in the sea, but the attempt failed, in consequence of these having been accidentally removed or destroyed.

In addition to the statement of the fishing of the Forth, we subjoin an instructive statement of the fishing at Wick, in 1862, prepared by the editor of the "Northern Fnsign." 
Journal giving the Commencement, Continuance, and Termination of the HerringFishing (Season 1862) at the Wick District.

\begin{tabular}{|c|c|c|c|c|c|c|c|c|c|c|}
\hline Date & & 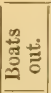 & 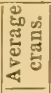 & 퐁 & 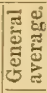 & 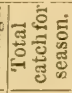 & Quality. & Weather. & Wind. & REMARES. \\
\hline July & & 20 & 2 & 40 & 0 & 40 & Excellent & Mild & WNW & \\
\hline$\ldots$ & & 30 & 1 & 30 & 0 & 70 & & & & \\
\hline ... & & 60 & $\frac{1}{2}$ & 30 & 0 & 100 & & Damp and mild & & \\
\hline$\cdots$ & & 50 & $0^{\frac{1}{2}}$ & 25 & 0 & 125 & D & Mild & NW & \\
\hline$\ldots$ & & $\begin{array}{r}70 \\
70\end{array}$ & $\begin{array}{l}0 \\
1 \frac{1}{3}\end{array}$ & $\begin{array}{r}10 \\
105\end{array}$ & $\begin{array}{l}0 \\
0\end{array}$ & $\begin{array}{l}135 \\
240\end{array}$ & $\begin{array}{c}\text { Good } \\
\text { Do. }\end{array}$ & $\begin{array}{l}\text { Gen } \\
\text { Bree }\end{array}$ & $\begin{array}{l}\text { SSE } \\
\text { NNE }\end{array}$ & \\
\hline ... & 11 & 120 & $2^{2}$ & 60 & $\frac{1}{4}$ & 300 & Do. & Cold and breezy & NW & \\
\hline$\ldots$ & 12 & 150 & 7 & 1,050 & $1 \frac{1}{4}$ & 1,350 & Do. & Fine & SSE & First cargo despatched, 423 bar- \\
\hline ... & 15 & 180 & 1 & 180 & $1 \frac{1}{4}$ & 1,530 & Mixed & Mild & $\mathrm{S}$ & 1 boat wrecked entering the harbour. \\
\hline$\ldots$ & 16 & 170 & 1 & & $1 \frac{1}{2}$ & 1,700 & Go & Clear-strong & NN & \\
\hline ... & 17 & 150 & 1 & 150 & $1 \frac{3}{4}$ & 1,850 & Do & Wet & NIV & \\
\hline & 18 & 100 & 1 & 100 & 2 & 1,950 & Do. & Thick and wet & E & \\
\hline ... & 19. & $\begin{array}{r}50 \\
300\end{array}$ & $\begin{array}{l}1 \\
3\end{array}$ & $\begin{array}{r}50 \\
900\end{array}$ & $\begin{array}{l}2 \\
3\end{array}$ & $\begin{array}{l}2,000 \\
2,900\end{array}$ & $\begin{array}{l}\text { Do. } \\
\text { Do. }\end{array}$ & $\begin{array}{l}\text { Ro } \\
\text { Mi }\end{array}$ & & \\
\hline & 23 & 600 & 2 & 1,200 & 4 & 4,100 & Excellent & & WV & \\
\hline & & 700 & 1 & 700 & $4 \frac{1}{2}$ & 4,800 & Do. & Changeable & S & \\
\hline$\cdots$ & 25 & 250 & $\frac{1}{2}$ & 125 & $4 \frac{1}{2}$ & 4,925 & Do. & Very rough & SIV & $\left\{\begin{array}{l}\text { Greater part returned without } \\
\text { shooting their nets. }\end{array}\right.$ \\
\hline ... & 26 & 700 & 1 & 700 & 5 & 5,625 & Do. & Mild & WV & (X) \\
\hline ... & & 950 & 0 & 150 & 5 & 5,775 & Do. & Mild and wet & NW & $\left\{\begin{array}{l}\text { Very strong tides. Considerable } \\
\text { loss of nets. }\end{array}\right.$ \\
\hline ... & 30 & 900 & $\frac{1}{2}$ & 450 & 6 & 6,225 & Do. & Do. & NW & 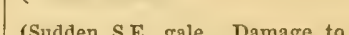 \\
\hline$\ldots s$ & 31 & 950 & 1 & 950 & $6 \frac{1}{2}$ & 7,175 & Do. & Rough & SSE & $\left\{\begin{array}{c}\text { Sudden S.E. gale. Damage to } \\
\text { boats entering the harbour. }\end{array}\right.$ \\
\hline Aug. & 1 & 250 & 2 & $\begin{array}{r}500 \\
2000\end{array}$ & 7 & $\begin{array}{r}7,675 \\
9,675\end{array}$ & Do. & Mild-heary sea & $\begin{array}{l}\mathrm{E} \\
\mathrm{E}\end{array}$ & \\
\hline ... & & 1000 & 2 & 2,000 & $8 \frac{1}{2}$ & & Mlis & & $\mathbf{L}$ & $\int 500$ boats went out, but most re- \\
\hline$\cdots$ & 5 & 150 & 1 & 150 & 9 & 9,825 & Good & Rough & SSE & $\left\{\begin{array}{l}\text { turned. } 4 \text { damaged entering } \\
\text { the harbour. }\end{array}\right.$ \\
\hline$\cdots$ & 6 & 70 & 3 & 210 & 9 & 10,035 & Spent & Do. & ES & (Two boats driven ashore leaving \\
\hline$\cdots$ & 7 & 1100 & 6 & 6,600 & 15 & 16,635 & $\frac{1}{3}$ spent & Mild & $\mathbf{E}$ & $\left\{\begin{array}{l}\text { the river-surf. Keiss aver- } \\
\text { aged } 23 \text { crans. }\end{array}\right.$ \\
\hline$\cdots$ & 8 & 1100 & 4 & 4,400 & 19 & 21,035 & $\frac{1}{4}$ spent & Thick and rough & $\mathrm{NE}$ & $\left\{\begin{array}{l}\text { Keiss averaged } 30 \text { crans, Wick } \\
\text { boats could not reach the fish- } \\
\text { ing-ground. }\end{array}\right.$ \\
\hline$\cdots$ & 9 & 700 & 6 & 4,200 & 23 & 25,235 & Do. & Do. & $\mathrm{N}$ & $\left\{\begin{array}{l}\text { One boat run down off Noss Head. } \\
\text { All boats out, but } 400 \text { returned. }\end{array}\right.$ \\
\hline$\cdots$ & 12 & 1120 & 3 & 3,360 & 26 & 28,595 & Good & Breezy & E & $\left\{\begin{array}{l}\text { Partial fishing. } 300 \text { returned } \\
\text { without shooting their nets. }\end{array}\right.$ \\
\hline$\cdots$ & 13 & 1120 & 8 & 8,960 & 34 & 37,555 & Excellent & Thick, wet, \& mild & 1) E & (Great loss of nets through the \\
\hline$\cdots$ & 14 & 1120 & 4 & 4,480 & 38 & 42,035 & Do. & Do. & NE & $\left\{\begin{array}{l}\text { weight of fish. Supposed loss, } \\
£ 4000 .\end{array}\right.$ \\
\hline$\ldots$ & 15 & 1100 & $\begin{array}{r}11 \\
8\end{array}$ & $\begin{array}{r}12,210 \\
8,000\end{array}$ & 48 & 54,245 & Do. & Do. & N & \\
\hline $\begin{array}{l}\cdots \\
\cdots\end{array}$ & & 1000 & & 8,000 & 56 & 62,245 & & & CW $\mathbf{W}$ & Three-fourths returned without \\
\hline $\begin{array}{l}\cdots \\
\ldots\end{array}$ & 19 & 1000 & 0 & 50 & 56 & 62,295 & Excellent & Strong gale & SW & ets. \\
\hline$\ldots$ & 20 & $\begin{array}{l}800 \\
800\end{array}$ & $\frac{\frac{1}{2}}{\frac{1}{4}}$ & $\begin{array}{l}400 \\
200\end{array}$ & $\begin{array}{l}56 \frac{1}{2} \\
57\end{array}$ & $\begin{array}{l}62,695 \\
62,895\end{array}$ & $\begin{array}{l}\text { Do. } \\
\text { Do. }\end{array}$ & $\begin{array}{c}\text { Gentle breeze- } \\
\text { Do. }\end{array}$ & $\begin{array}{l}\text { SW } \\
\text { SSW }\end{array}$ & $\begin{array}{c}\text { Tides very dead. } \\
\text { Do. }\end{array}$ \\
\hline$\cdots$ & & 900 & $\frac{\pi}{2}$ & 450 & 57 & 63,345 & Do. & Calm and clear & Variable & the folving \\
\hline$\cdots$ & 23 & 800 & $\frac{x}{4}$ & 200 & $57 \frac{1}{2}$ & 63,545 & Do. & Very wet \& calm & Do. & $\left\{\begin{array}{l}\text { Boats unable to reach the fishing- } \\
\text { ground. }\end{array}\right.$ \\
\hline$\ldots:$ & 26 & $\begin{array}{l}1120 \\
1120\end{array}$ & $\begin{array}{l}2 \\
5\end{array}$ & $\begin{array}{l}2,240 \\
5,600\end{array}$ & $\begin{array}{l}59 \\
64\end{array}$ & & & $\begin{array}{l}\text { Mild } \\
\text { Breezy }\end{array}$ & $\begin{array}{l}\text { Do. } \\
\text { ESE }\end{array}$ & \\
\hline$\ldots$ : & 28 & 1120 & 1 & 1,120 & 65 & 72,505 & Good & Clear and mild & Variable & f Boats unable to reach the flshing- \\
\hline$\cdots$ & 29 & 100 & $\frac{3}{4}$ & 800 & $65 \frac{1}{2}$ & 73,305 & D & Do & Do. & $\begin{array}{l}\text { I ground. } \\
\text { Do. }\end{array}$ \\
\hline Sept. & 30 & 00 & $\frac{1}{2}$ & 500 & 66 & & Do. & & $\mathbf{E}$ & \\
\hline & 2 & 1050 & $\frac{1}{3}$ & 525 & 66 & 74,330 & Excellent & Breezy & E & $\begin{array}{l}\text { One boat run down. } \\
\text { (Boats could not get out from surf }\end{array}$ \\
\hline $\begin{array}{l}\cdots \\
\cdots\end{array}$ & 3 & 20 & $\frac{1}{2}$ & 10 & $66 \frac{1}{2}$ & 74,340 & Do. & Do. & E & $\left\{\begin{array}{l}\text { at harbour. Smooth outside. } \\
\text {. Smo }\end{array}\right.$ \\
\hline $\begin{array}{l}\ldots \\
\ldots\end{array}$ & $\begin{array}{l}4 \\
5\end{array}$ & $\begin{array}{r}20 \\
100\end{array}$ & $1^{\frac{1}{2}}$ & $\begin{array}{r}10 \\
100\end{array}$ & $\begin{array}{l}66 \frac{1}{2} \\
66 \frac{1}{1}\end{array}$ & $\begin{array}{l}74,350 \\
74,450\end{array}$ & $\begin{array}{l}\text { Do. } \\
\text { Do. }\end{array}$ & $\begin{array}{l}\text { Do. } \\
\text { Mild }\end{array}$ & $\begin{array}{l}\mathrm{E} \\
\mathrm{NE}\end{array}$ & \\
\hline ... & G & 600 & $\frac{x}{4}$ & 15 & $67^{2}$ & & & D & $\mathrm{NE}$ & \\
\hline & 9 & 220 & $4^{-1}$ & & 68 & & & D & Sy & \\
\hline & 10 & 300 & 10 & 3,000 & 71 & & & & & \\
\hline$\ldots 1$ & 11 & $\begin{array}{l}400 \\
400\end{array}$ & $\begin{array}{l}20 \\
10\end{array}$ & $\begin{array}{l}8,000 \\
4,000\end{array}$ & $\begin{array}{l}77 \\
81\end{array}$ & & & $\begin{array}{l}\text { Do. } \\
\text { Breezy }\end{array}$ & $\begin{array}{l}\text { SW } \\
\text { SW }\end{array}$ & \\
\hline ... 1 & 13 & 3 & 4 & 12 & 81 & $|90,492|$ & Good & Wind and rain & SW & $\{400$ boats out, but had to return- \\
\hline$\ldots 1$ & 16 & $\begin{array}{l}200 \\
200\end{array}$ & $0^{\frac{3}{4}}$ & $\begin{array}{r}160 \\
12\end{array}$ & $\begin{array}{l}81 \\
81\end{array}$ & $\begin{array}{l}90,652 \\
90,664\end{array}$ & $\begin{array}{l}\text { Do. } \\
\text { Do. }\end{array}$ & $\begin{array}{l}\text { Mild } \\
\text { Do. }\end{array}$ & $\begin{array}{l}\text { Variable } \\
\text { Do. }\end{array}$ & \\
\hline
\end{tabular}


We especially call attention to those parts of the table which represent the dangers the fishermen are subjected to, in conserquence of the want of a good harbour at IVick.

The following tables represent the quantity cured and fished during the year 1862, at the various fishing stations.

HERRINGS FISHED OR CURED IN 1862 :-

At the Stations, North-cast Coast.

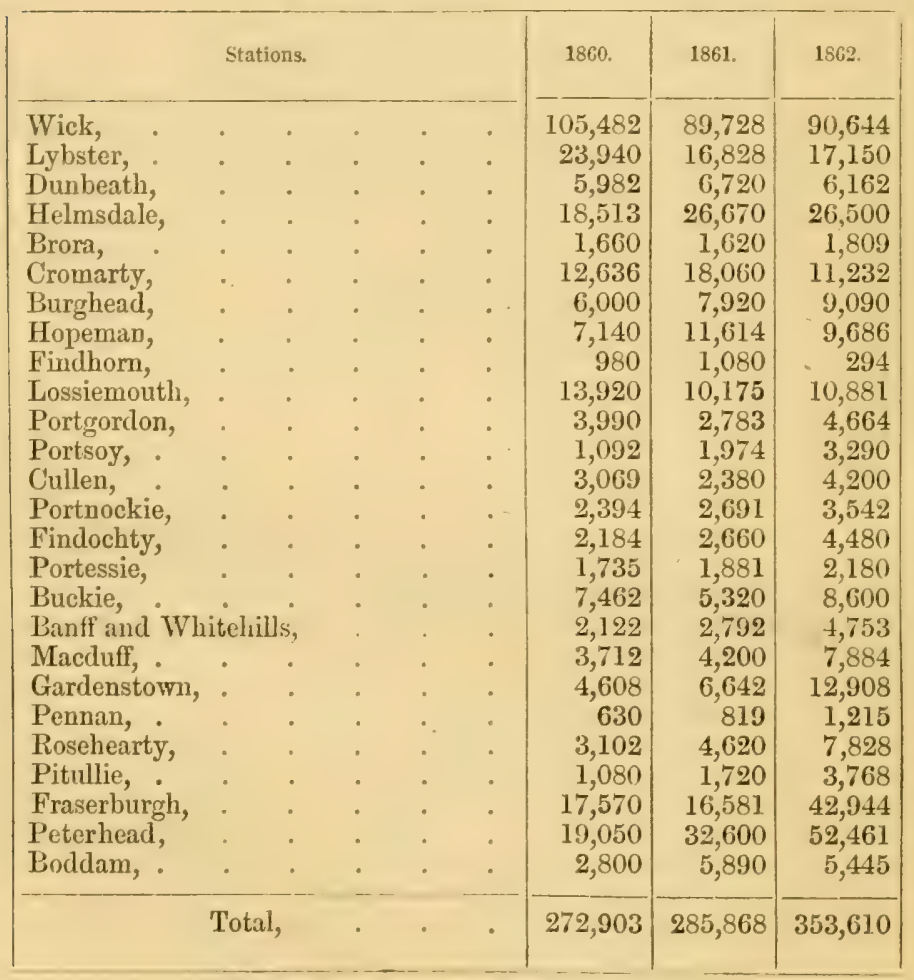


CHRONOLOGICAL HISTORY OF THE HERRING-FISAERY. 315

Barrels.

Brought over, 353,610

South-cast District.

Stonehaven Section,

Barrels Cured.

Anstruther District, . . . . 44,079

Leith District, . . . . . 5,372

Eyemouth District, . . . . 51,729

Total, . - 136,397

C'aught and sold fresh at the following Districts on the East

Coast of Scotland, Fishing 1862 :-

Districts.

Leith,

Eyemouth,

Shetland Isles,

Orkney Isles,

Wick,

Lybster,

Helmsdale,

Cromarty,

Findhorn,

Buckie,

Banff,

Fraserburgh

Peterhead,

Anstruther,

Greenock,

Rothesay,

Inveraray,

Loch Carron and Skye,

Loch Broom,

Stornoway,

Total West Coast of Scotland,

$$
\text { Total, }
$$

$$
\begin{gathered}
\text { Barrels } \\
\text { Salted or Cured. } \\
562 \\
3,072 \frac{1}{2} \\
79,705 \\
5,900 \frac{1}{2} \\
4,222 \\
78,480
\end{gathered}
$$

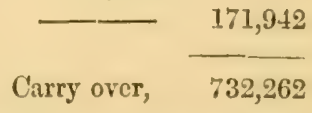

In addition, it is computed that 14,256 harrels of herrings 
were consumed fresh, without being salted, according to the following returns collected by the officers so far as practicable; but it is not possible to get returns of herrings "consumed fresh" with the accuracy of returns of "cured herrings."

\begin{tabular}{|c|c|c|c|c|c|}
\hline \multirow{2}{*}{\multicolumn{3}{|c|}{ Districts. }} & \multicolumn{2}{|c|}{ Brought over, } & \multirow[t]{2}{*}{$\begin{array}{c}\text { Barrels. } \\
732,262\end{array}$} \\
\hline & & & & $\begin{array}{l}\text { Caught but } \\
\text { not Cured. } \\
\text { Barrels. }\end{array}$ & \\
\hline Greenock, . & . & . & . & 5,080 & \\
\hline Rothesay, . & . & . & . & 366 & \\
\hline Inveraray, . . & . & : & . & 2,440 & \\
\hline Loch Carron and Skye & . & . & . & 3,670 & \\
\hline Loch Broom, & . & . & . & 690 & \\
\hline Stornoway, . . & . $\quad$. & . & . & 2,010 & \\
\hline \multicolumn{2}{|c|}{ Total West Coast of Scotland, } & & . & - & 14,256 \\
\hline \multicolumn{5}{|c|}{ Total fishing for 1862-barrels, } & 746,518 \\
\hline
\end{tabular}

To complete the tables, we now give the progress of the fishing since 1848 (as to the fishing in the preceding years, see page 259) ; and as the year 1849 was very remarkable for its productiveness, we give the following particulars of that fishing:-

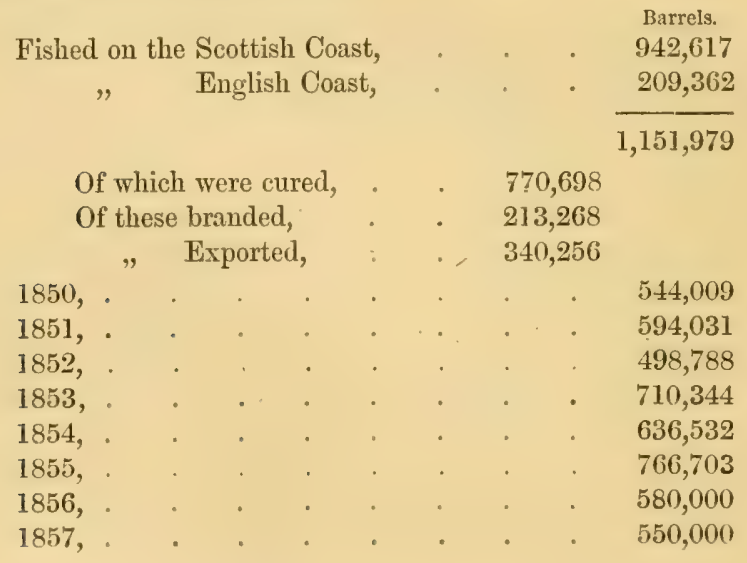


CHRONOLOGICAL HISTORY OF THE HERRING-FISHERY. 347

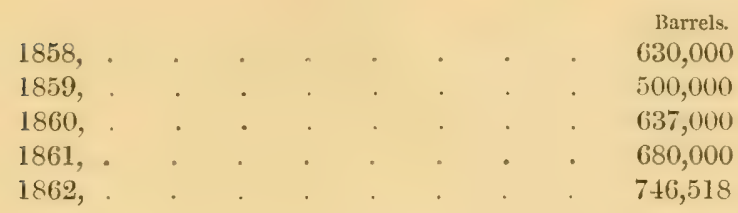

As it has been asserted that the fishermen are only employed part of the year, and that merely in the herring tishery, we think it but doing them justice to give a short account of the usual occupation of the Newhaven and neighbouring fishermen.

In January the fishermen are actively employed: some at the oyster dredge; some proceed to fish the winter herrings in the Firth; some to fish sprats; and others to the cod, ling, haddock, and skate fishings.

These may be considered the occupations of the fishermen for the different months down to May. In this month, and in June, the majority of the enterprising fishermen proceed in their open boats to prosecute the herring-fishery at various places in the north of Scotland, sometimes as far as Stornoway in the Lewis Islands, many to Wick, Banff, Fraserburgh, \&c., and continue fishing there about two months; and sometimes catch to the extent of 350 barrels per boat.

After returning from the northern fishing, some of them proceed to Dumbar, Eyemouth, and other places on the coast of Berwickshire and Northumberland, in pursuit of herrings there, where they are frequently very successful. In September the oyster fishery in the Forth commences, which continues till May, and which affords to many a never-failing but generally scanty means of support during that period. As many as eighty boats may be seen in a 
morning at the cheerful but laborious dredge; they commence about four or five, and finish about ten or eleven o'clock in the morning.

Others set their "partan" (crab) nets on rocky ground, or their skate-nets to the east of Inchkeith, or proceed to the fishing-banks off the mouth of the Forth to fish haddocks, cod, ling, halibut, and skate, until the time of the herring-fishery again comes round. Many of them unite to the occupation of fishermen the equally hazardous but more responsible profession of pilot; and it is not uncommon for them to be eight days absent, beating about in their open boats in the ocean, in quest of ships. Their mode of life is certainly of a very exciting nature; at one time they are-in the months of June, July, and August-in their open boats in the ocean, 200 miles from home; at another they are employed, in the cold, stormy, and dreary nights of winter, in the same occupation in the Firth of Forth; or they proceed amidst darkness aud hurricanes to the oyster-fishing or piloting. In the sumny mornings of May, they skim along to the "hekle" or "hettle" rocky grounds, the favourite haunts of the crab and lobster, to set their traplike "corv" or box, or nets; or to the deep water of the Firth, to sink their skate nets. Compared to the landsman on his downy pillow, the sailor's is considered a life of hardships; but he has his forecastle for shelter and his hammock for a bed, while the fisherman spends his nights in the middle of winter on the ocean, in an open boat, happy to snatch a nap on the boards if the spray or the waves will allow him,-and this not only for one night, but for many nights in succession. We have often seen the fishermen landing from their boats with their faces incrusted white with the salt of the ocean, and yet 
we hardly know an instance of a fisherman or fisherman's son preferring another profession to a seafaring life, so much have example and habit wedded them to their dangerous and exciting avocation.

\section{SUGGESTIONS AS TO THE IMPROVEMENT AND EXTENSION OF THE HERRING-FISHERY.}

1. All British fishing vessels and boats ought to be exempted from paying any charge whatever in the shape of liarbour dues, lights, petty customs, or tithes,-the vested rights as to petty customs or tithes to be protected by commutation, and paid for by assessments on the torvns or communities where such exactions are made.

2. It is of the utmost importance for the proper preservation of the herring, that it be carefully protected from sun, wind, and rain, after being shaken out of the nets into open boats; this is not at present sufficiently attended to. We would suggest that each boat proceeding to the herring fishery should be provided with a moveable deck or covering, to be applied after the nets are taken in; this ought either to be enforced by law, or the practice encouraged by a small bounty or premium.

3. Considerable shoals of herring often come upon coasts and into bays, particularly in the North and West IIighlands, where there may be few or no fishing-boats, while, at the same time, many fishing-boats may be lying unemployed for want of herrings at other localitics. It would be highly beneficial that immediate intelligence of the arrival of such shoals be communicated to the fishery-officers at the adjacent stations, who, in such cascs, might immediately send information to such localities, and the other stations, by notices in the newspapers, de. 
4. Encouragement should be given to the fish-curer to cure the herrings in oaken barrels; the Dutch do not generally cure in any other. We are of opinion that oak is not only, from its strength and retentive quality, the best suited for this purpose, but that there is also a preservative quality in this wood, and that it moreover imparts a pleasant flavour to the herring.

5. Every means should be adopted to improve the manufacture of salt. The salt manufactured in this country is generally of very inferior quality; and the same common process of boiling or evaporation has been followed for centuries. Simple evaporation does not leave the pure preservative salt or muriate of soda.

Our common salt is composed of-

\author{
Muriate of Soda, or Pure Salt. \\ Sulphate of Magnesia, or Epsom Salt. \\ Muriate of Magnesia. \\ Muriate of Lime. \\ Sulphate of Lime.
}

The sulphates and muriates of magnesia and lime are injurious to the process of curing.

The muriate of magnesia is partly detached from the common salt in a liquid state, and forms a great portion of the liquid collected at salt works called bittern, from which magnesia is made; but it is evident that a great part must remain with the crystals under the common process of manufacture. The sulphate of magnesia, or Epsom salt, is also contained in the bittern, but part remains with the crystals. These, as well as the muriate and sulphate of lime, besides giving a disagrecable taste to the common salt of this country, interfere with, or to a certain extent prevent, the antiseptic qualities of the pure salt. 
Various plans have been suggested to get rid of these deleterious substances, but unfortunately no process has been generally adopted in this country for this purpose. The Dutch make their salt of great purity, by melting down the common rock-salt in pure sea-water brought from the sea at a considerable distance from the shore. They make the different kinds, suitable for different purposes, with great care; the secret of making which was purchased by them from the city of Cologne.* In the present advanced state of the science of chemistry, it certainly would be no difficult matter to find out some simple and cheap process for purifying an article so materially connected with the health and prosperity of the inhabitants of this country. We believe that many of the fishcurers now use Spanish and other salt, of greater purity than our common salt, with advantage.

We have had specimens brought over of the different kinds of salt manufactured in Holland, and found that there were several sizes of crystals, forming cubes, the finest of an inch square, and downwards, according to the strength required. We believe the superiority of the Dutch cured herrings, butter, \&c., is much owing to the purity of the salt.

6. We have in a previous part of this work endeavoured to explain the cause of the diminution of the quantity cured of red or smoked herrings, which in former years was very large in some of the fishing towns-such as Wick, Eyemouth, Dumbar, Anstruther, \&c. Now, it is very well known that, in the curing process of red herrings, the assortment of the kinds, the size of the

* See Prize Essay on the "Dairy Husbandry of Holland," Quarterly Journal of Agriculture, No. 23, and IIendrick's Ilistory of the Island of Arran. 
barrel, and the number in the barrel, are not in any way subjected to the inspection of the fishery officer, there being no law as yet applicalle to the curing of red-herrings ; the trade in most places has therefore very much decreased.

We have often seen the red-herrings, sold by the principal curers, examined, and found the barrels filled with a mixed variety of inferior fish-the barrels too small, and the herrings improperly packed; so that orders to purchase from foreign countries have much diminished, and now the curers at the principal port, Yarmouth, have to ship the greater part to the Mediterranean for the chance of sale, and often lose considerably by such shipments. We consider that if the red-herring cure were placed by the Fishery Board under proper legislation, the quantity required for consumption abroad would be largely increased; one inferior cargo sent by an inferior curce to a foreign port will tend to destroy the trade.

7. The boundary line, beyond which foreign fishing vessels should fish, ought to be laid down on a chart, published by authority of Government. Continual disputes occur at the fishing stations where foreign vesscls resort to fish; and it would be protecting the foreign and British fishermen were the line distinctly marked. We may refer to the "Report of the Commissioners for the British Fisheries for the year 1851," to show the difficulties that arise on such points. In this report we find it stated,"that upon the East Coast the disputes between our fishermen and the French grew to be so serious and frequent, that it became necessary to apply for more force;" and the Lords of Admiralty sent an additional war steamer to assist those ships already acting for the same purpose. And in the same report we are told that "a question of boundary was raised by the French Commo- 
dore in regard to the Fern Islands, the interpreting the boundary line to be three miles from the mainland, which would have allowed the French to fish close to the Fern Islauds, while Captain Strange, of H.M.S. Archer, held the boundary to be three miles outside of low water-mark of the Fern Islands. Ultimately the case was remitted to the Quecn's Advocate, who determined that the boundary was three miles outside of the Fern Islands." The said report farther states, - "The Tartarus war steamer, being able to come near the shore, was very successful in detecting and putting a stop to infringements of the Convention;". and "the masters of several of the French vessels were brought before the magistrates and fined." Now fining looks very plausible, but we suppose the fine would not exceed L.5, while no doubt L.50 or L.100 value of herrings had been fished within the limit or boundary. "They order this matter better in France;" for if any of the English oyster-fishermen are found dredging within the boundary on the French coast, we are informed that they are detained for a considerable time, sometimes until after the fishery. We own, rather than run the risk, from such dangerous proximity, of disputes with a friendly power, that it would be better to abandon the oyster-fishery limits on the French coast, and arrange that the boundary for fishing on the British coasts should be, as formerly, at three leagues, the actual legal boundary beyond which all strangers can be compelled to keep when so occupied, and we give a strong reason for this in our next observation; but we must point out the great necessity of some strict arrangement, or permanent supervision, by the continued presence of ships of war or naval row-boats, as on the coast of Norway fishery, because, when large fishing vessels take up 
the fishing ground where there are herring shoals, the small fishing boats belonging to this country are fairly driven off by the greater size of the fishing slips and the heavier nets, against which the fishermen have no remedy unless there is constant permanent strong protection on the spot, under a naval officer, assisted by the fishery officer. TVe have been informed, that at a certain and important locality, where the shoals usually appear, there have heen watchmen from the larger ships sent on shore and placed on the headlinds adjacent, to give notice by signals, so that they may have time to leave the invaded boundary line before the approaching Government steamer comes near. This alone proves the necessity of the fishermen having LOCAL AND CONTINUOUS PRO'TECTION; but such protection is necessary in some places where there is no fishery officer, to act as a controlling influence among the fishermen generally. For instance, some time since, we real the following paragraph, as applicable to Killybegs in Ireland:- "The want of law is " more evident than ever; everything injurious to the "fishery is practised, such as shooting nets by day, vessels "sailing through the nets, breaking nets, and cutting away " nets. Surely Such a source of great wealth sirould " HAVE SOME PROTECTION."

8. Those vessels which, after gutting the herrings on board, throw the refuse into the sea, ought not to be permitted to fish where there are herring shoals; and this law ought to be enforced by the Dutch Government (whose fishing vessels cure on board), which might order that the portions taken out of the herring at gutting loe barrelled up for use, for the purpose of making oil, or for manure, or for both purposes. The herring is very capricious, and we have before stated instances where the 
shoals have been driven awa', such as from the Swedish coast, where about the same quantity was fished as on our coasts, and where they were scared away by continuous fishing night and day, and (what was still more pernicious) by allowing the refuse of the herrings, boiled at places on the coast for the purpose of obtaining the oil, to reach and taint the sea,-and the shoals never returned.

10. When the importance of encouraging the fishermen in this important occupation is considered, surprise may be expressed that the British Government has done so little towards providing suitable harbours for the fishermen-to enable them to proceed out and in and lie in safety at all times. In a very able pamphlet, written by Mr Mackie of the "Northern Ensign," Wick, we are told "that the reason why the loss of life on such a dangerous coast (Caithness) is now so comparatively small, is because the fishermen will not venture to sea when there is the least appearance of a breeze, knowing too well what they must meet if overtaken by a gale, and are obliged to run for land." This circumstance has every year a serious effect on the fishing. This is not " making two blarles of grass grow where only owe grew before." Mr Mackie goes on to say, "In one gale (off' Wick) upwards of fifty boats, lying at anchor in the bay, were overtaken ly a sudden gale, and foundered. On another occasion thirty-seven Wick fishermen were drowned in an hour; and since 1845 about one hundred and fifty fishermen have been drowned, and about four liundred boats wrecked, in that neighbourhood." We may contrast the neglect of harbour accommodation for our fishermen and mercantile marine on the Scottish coast, with the millions of pounds spent on hingiston and Tholyliead harbours. TVe have to remark, that a truly pa- 
356 CHRONOLOGICAL HISTORY OF THE HERRING-FISHEIY.

triotic body, the British Fishery Society, has endeavoured to supply, partially, the defects at Wick-in consequence of the backwardness of the Government-and has applied for an act to authorise the enlarging and improving Wick or Pulteney Town harbour, but has met with much unmerited opposition, which might have been avoided had the Government acted upon the unanimous opinion of those gentlemen best acquainted with the importance of erecting such a harbour there. 


\section{N D E X.}

Aberdeen, fishery established at, in 1836, 236 .

Aberdeenshire Coast, visits of herring, 63 .

Acts of Parliament erroneous, 3.

King Charles II., 1661, 171.

William and Mary, 1620 and 1693, 174.

William I., 1698, 182.

Queen Anne, 1704, 188.

George I., 1727, 188.

George II., 1750, 204.

for extension of fisheries, 208.

George III., bounty on cured herrings, 222.

Do appoints Fishery Board in 1808, 226.

Do. $1815,228$.

for Irish Fisheries, 229.

George IV., 1819-1820, 230.

Do. 1821, abolishes tonnage bounty, 232.

Do. cap. Ixiv., 1824, abolishes bounties, 23 :

William IV., cap. lxiv., 1830, 235.

15 Victoria, cap. xxvi., 1851, as to cure, 265.

13th August 1860, 327.

14 and 15 Victoria, cap. xxvi., 1851, as to mets, 329

1st August 1861, 24 and 25 Victoria, cap. Ixxii, as to herring fry, 334.

Agassiz as to food of herring, 53 .

Alca alva, 87.

- arctica, 87 .

Alice shad, 41.

America, herring visits various, 81 .

American Transactions, 81.

Anchovy described, 41.

Anchoring nets, 93.

Anderson's History of Commerce, 130, 155.

Anderson, Thomas, Glasgow, condemns trawl-nets, 290.

Angus herring fishery, 66.

Annapolis Basin, herrings abuudant, 82. 
Appearance of whales, \&c., 23.

Ardglass, considerable herring station, 72.

Argyle Coast, visits of herring, 56 .

- John, Duke of, anecdote, 193.

Arklow, change of season for herrings, 72 . boats, 299 .

Arnoldus de Lubeck's Chronicles, 133.

Arran, visits of herring, 61 .

Artificial flies, 38.

$\Lambda$ sia, various herring visits, 80 .

Astecus (roe-aat), 48.

Avatska, Bay of, shoals of herrings here, 80 .

Ayrshire Coast, visits of herring, 62 .

Ballinalkill, herring visits, 70 .

Balana musculus, 35. mysticetus, 34, 87 . - rostrata, 35.

Baltic, various visits, 78 .

Banffshire Coast, herring visits, 63 .

Bantry, herring visits, 72 .

- Bay, trawling prohibited, 320.

Bathurst Inlet, herrings caught in, 81 .

Battle at Dunbar by fishermen, 340 .

Barne Pier, 333.

Barrels of oak best, 350 .

Barry, Commissioner, 296.

L Report as to Devonshire fisheries, 277.

Beam-trawling, Ireland, 274, 329.

occasioning breach of the peace, 330 .

Beechy's Voyages, 81.

Behring's Straits, herrings in July and September, 81 mode of fishing, 110.

Belfast Lough, shoals sometimes, 72 .

mode of fishing, 110.

trawling, 300.

Bellenden's Boece's Albion, 142.

Bergen herring fishing in 1857, 301.

herring visits, 75 .

Berwick, herring visits, 67 .

Beukelsen, celebrated as the inventor of curing, 134.

Biggar, Walter, Pamphlet in favour of Board, 295.

Billing's Northern Regions, 80.

Bjornebjorg, herrings in spring, 78.

Black Sea herring-fishery, 80 .

Blanket herring fishing, 100.

Bloch as to migration, 88 . 
Blom's Travels, 75 .

Blotters, 121.

Blowit, states herrings early a royal dish, 136 .

Board of Trade, Queries of, 303.

Boats, ancient, found, 129. must be marked, 328 .

Book of Meaux, 136.

Bornholm, herring-fishery here, 78.

Bose on food of herring, 52.

Bothnia, Gulf of, small herrings fished here, 79. - mode of fishing, 109.

Boundary line for fishing, 352.

Bounties allowed, 190.

- in Scotland, 210.

on cured herrings, 214.

on herring-fishery, 230.

- - on tonnage, 218.

Bounty on herring reduced, 211.

Brady's, Commissioner, Report, 331.

Brand, opinions in favour of, 298.

Brandersund, 301.

Bremen complains of tax for fishing, 156.

British Fishery Society, 219, 356.

Wick Harbour, 1824, 232.

purchase land, 220.

Brittany, sardine fishery of, 124, 324 .

Broadhaven Bay, herring visits, 70.

Buchan Ness, herring visits, 65 .

Buoys, 92.

to be marked, 328.

Burghe Tollys, 132.

Caithness, visits of herring, 56 .

Cape Wrath, visits of herring, 63 .

Carlingford Lough, herrings diminishing, 72.

Carolina herring fisheries, 81.

Carrickfergus, herring shoals visit, regularly, 72

Caspian Sea, extensive herring fishery, 80.

Cause of failure of red-herring trade, 122.

Cedric the Saxon, 131.

Chamber of Commerce as to duties of fish in France, 32.2.

Report, 327.

Charles V. of the Netherlands, treaty with James V., 145.

Charlestown, 341.

Chart for boundary line recommended, 352.

Christiansund, summer herring fishery, 75 .

Chronological History, Book III. chap. i. page 129. 
Circular nets, 38.

Claddagh fishermen, 71.

destroy herring boat, 334 .

Cleghorn, Mr, of Wick, his remarks, 38.

Cleghorn's letter on diminution of herring, 292.

Cloquet on food of herring, 52.

Close time for fishing herrings, 327.

Clupea, 40.

Clupeidae described, 41.

Clyde, visits of herring, 61.

Cobden, R., letter from, as to French tariff, 325.

Cockburn, Joseph, scheme for retrieving fisheries, 199.

Cod-fishery, French, 324.

Cod, the, devours herring, 36.

Collins, on salt and fishery, 172.

Cologne salt, 351.

Colony, fishing, at Lewis, 154.

Colymbus Glyde, 87.

Comines, Philip De, Memoirs, 141.

Commerce occasioned by fisheries, 20.

Commercial ambassadors, advantage of, 326 .

Commission of inquiry as to brand, 314 . to inquire as to fishes, $1630,158$.

Commissioners as to French tariff, 326.

- for manufactures, \&c., appointed 1726, 225.

- may fix limits for sprat fishing, 335.

Price and St John's report, 314.

Common salt deleterious, 350 .

Commons, House of, Committee as to herring fishery, 224.

Company formed to promote fisheries, 204.

Connal Abbey, charter, 141.

Considerations upon herring-fishery, 200.

Convention, infringements of, 353.

Cormorant feeds on herring, 37 .

Cornish fishermen, 69.

Cornwall Coast, visits of herring, 69 .

Costello, herring visits, 70 .

Craigleith, 342.

Crangon vulgaris, 87.

Cromarty, visits of herring, 64 .

Croyland, ancient Chapter of, in 1305, 138.

Cruive for taking herring, 38.

Cruives, 95.

Curing, Modes of, 91, and Book 11. chap. ii. page 111.

Scottish mode, 111.

Barrels-Heads-Hoops-Dunting-Blowing-Branding-Salt,

111. 
Curing, Dutch mode-

Gutting, assorting, packing, 115.

Salt, blowing, marking, 116.

Oil, inspection, barrels, 117.

Hoops, marks, and brands, 118 .

Curragh fishing, 100.

Customhouse charges, heary, 219.

Customs duties, prohibitory, 218.

Cuvier on food of herring, 52.

- quotation from, 2.

-_ History of Fishes, 82.

Cyclopteris viperus, 88.

Daily take at Wick, 313.

David I., charter to Holyrood, 132.

Denmark herrings, small, fished, 76 .

Description of herring, 42 .

Destruction of life at fishing, 356.

Dieppe, herrings off, 79.

Dingle Bay, herring shoals, 71 .

trawling prohibited, 319.

Discussion as to sprats and young herring, 265 .

Disputes with Erench fishermen, 352.

Diver feeds on herring, 37.

Diving for spawn, 341.

Dodd, Dr James Silvis, Essay on herrings, 206.

Dog-fish destroys herring, 36.

Donegal, county of, 332 .

Doomsday Book, 131.

Douglas, visits of herring; 63.

Dorrn County, Coast of, shoals considerable, 73 .

Dredging may destroy herring spawn, 38.

Drontheim, herring visits, 74 .

Duich Loch, visits of herring, 59.

Dunbar, fishery abundant off, 1861, 339. visits of herring, 67.

Dundrum Bay, trawling prohibited, 319.

Dunsmure, Mr, first secretary Fishery Board, 229.

Dutch busses, 102.

- deep-sea fishing, 32.

- fishery, 101.

- fishery laws, 103, 105.

- fishing towns, 308.

fishing ressols ought to barrel up refuse, 354 .

Great fishery, 101.

fishery attacked by the Dunkirkers, 201.

herring-fishery Reports, 1858, 307. 
Dutch jagers, 103.

- new fishery laws, 105.

- Pan fishery, 101.

- salt superior, 351 .

- signals, 108.

- Small fishery, 101.

Duties, new French, on herring, \&c., 326.

- on fish, reduction in France, 322.

on fresh-ivater fish, 326.

Duty on cod-fish, 326.

Earl of Dundonald's pamphlet on Herring-Fisheries, 215.

Edward the First's edict as to herring fair, 136.

Efforts to promote the fisheries described, 208.

Egede's Greenland, 88.

Elixir of herring bones, 207.

Elsinore, small herrings fished off, 76

Enemies of the Herring, chap, iv. page 34.

English Coast, herring visits, 68 .

Entomostraca, food of herring, 51.

Epsom salts, 350.

Errors in scientific works, 6-13.

Esprevar, 301.

Experiment with lights, 27.

Eyemouth, herring visits, 67 .

Fabricius on food, 51.

Fairhead, herring visits uncertain, 72.

Fall, Messrs, of Dunbar, large curers of red herrings, 212.

Robert, 216.

Falsterboe, small herrings fished, 76.

Farland Point, Coast of, herrings visit twice a year, 73 .

Faroe, herrings seldom seen, 74 .

Favourable appearances, 33.

Fecundated spawn, wonderful power of, 30 .

Fern Islands, 35 s.

Festival, amusing account of, in 1444, 140.

Fifo fishermen, battle with Newhaven fishermen, 340 .

Fishermen improperly disturb spawning, 339.

- seldom change their profession, 349.

— trust too much to appearances, 82 .

- dangers for want of harbours, 344.

- experience of, 25.

- life harder than seamen's, 348.

Fishery Board attacked, 246.

Commissioners may be increased, 329.

Board established in Holland, 1857, 307. 
Fishery Board, expense of maintaining, 247.

- Board petition against duties, 323.

- Convention Act with France, 1843, 242.

- duties, report on, 322 .

- limits should be extended, 353.

- officers, advantage of, 299.

- officer's duties, 318.

- officers should notify arrivals of shoals, 349 .

Fishing and curing, 91.

- boats and vessels ought to be free from dues, 349 . ground, 93.

herrings, prohibitive limits, 327.

Firth of Forth, herring visits, 66 .

Flekkefiord, Coast of, herrings left since 1836, 75.

Fluke Hole, 341.

Foggo, Robert, of Leith, takes Dutch busses, 145.

Food, chap. vi. page 48.

Forbes, Duncan, President, anecdote, 193.

Foreign exportations, 17.

_ large fishing-vessels injure our fishermen, 354.

Foreigners came to buy only at Yarmouth, 137.

Form of nets, 26.

Fox Island, autumn herring-fishery, 82.

France, Channel fishery, 79.

- earliest notice of herrings, 134.

Franklin's Polar Seas, 81.

Fraserburgh, herring visits, 65, 314 .

Fraser's Domestic Fisheries, 206.

Frederick II. of Denmark, superstition of, 152.

Free British Fishery Society, 209.

French Academy on migration, 3. - duties on fish prohibitory, 323. - vessels, masters of, fined, 353.

Fresh-water fish in France, 324.

Frost's Early History of Hull, 137.

Fundy, Bay of, herring-fishery, 81 .

Gadus carbonarius, 88.

Galway Coast, herring visits, 70 .

Bay, report as to fishing, 331.

- Bay, trawling proliibited, 319 .

Gammarus, food of herring, 51.

Gannet destructive of herring, 37.

Gilfillan the poet's description of fishery, 237

Glendhu, herrings abundant at, 307.

Gleninagh Castle, 333.

Gold-diggings inferior to fisheries, 6 . 
Gorernment, backwardness of, $35 \%$.

Gradual approach of herrings, 312.

Grant's proposals for herring-fishery, 197.

Great Belt, summer and winter herring-fishery, 78.

Greatman's Bay herring-fishery, 70.

Grimsby, complaints in 1291 of forestalling herrings, 137.

Ground selected for spawning, 29.

Gull feeds on herring, 37.

Gullan Ness, 341:

Hatits of Herping on Coasts, chap. iii., page 22.

Hanse Towns, off, fishery ceased, 79.

Harbour accommodation required, 355 .

$$
\text { grants for, } 233 .
$$

Harderwyk, 311.

Harold Graveld, 132.

Harris, herring visits, 61 .

Hastings boats fishing herring, 69.

- fishery, 98.

Hauling-nets, 98.

Helmsdale, herring risits, 63.

Herring boat destroyed at Claddagh, 384 .

Herring fishermen brought from Holland, 206.

Herring-fishery, suggestions as to improvement, 343 .

Herring spawn kept alive, 342.

- spawn in boxes at sea, 342.

- specific characters, 40.

- caught by Dutch busses in $1857,309$.

- cured without salt, 128.

- examined, 336-339.

- exportation of, from Holland, 309.

- off Norway, large size, 301.

- on surface, 24.

- scared away, 355.

Hettle, 348.

Highland Society's Transactions, vol. ii., 214.

Highlands, North, fishery in 1857, 158.

Holland, herring-fishery falling off, 308 inferior off this coast, 79 . legislation, 4.

Holyhead harbour, 356.

Hooks, baited and unbaited, take herrings, $\$ 8$

Horegesund, Norway, 301.

Horses, fishing herrings with, 100.

Horrebow's History of Iceland, 74.

Howitt's Visits, 149. 
Iceland, Coasts of, herrings uncertain, 74 .

Icy-sen herrings, 80.

Implements to be marked, 328.

Importance of herring-fishery, 1.

Important facts discovered, 28.

Improvement of salt recommended, 350 .

Increase depends on demand, 15.

Injuries to herring shoals, 39.

Invergordon, visits of herring, 64 .

Inverness, visits of herring, 56 .

Irish began fishing in 1202, 141.

Board's by-laws on trawling, 333 .

Coast fishing, 98.

Coast, visits of herring, 70 .

Commissioners prohibit trawling, 318.

Commissioners' Report, 101.

Irvine, visits of herring, 62 .

James V., treaty with the Netherlands, 1541, 145,

Journal of Wick fishing, 1862, 343.

of Winter fishery, 335.

kept in Dutch busses, 311.

Kamtschatka herring-fishery, 80.

Katwyk, 311.

Kenmare, herring visits, 71.

Kent Coast, shoals of herrings off, 69.

Keppel's Persian Narrative, 80.

Kerry Coast, herring visits, 71.

Kiel, herrings inconsiderable, 78 .

Killeries Coast fisheries, 70.

Killybegs, herring visits, 70 .

- want of protection at, 354 .

King Charles I. encourages fishery, 156.

Charles I., message from, 159.

Charles II. promotes a Royal Fishery, 163.

Eric of Norway refused permission to fish, 137.

George II. recommends fishery, 1749, 194.

James VI. prohibits fishing by foreigners, 155.

Kingston harbour, 356.

Kinnaird Head, herring visits, 65.

Kinær, fishing off, 301.

Kippered herrings, 121.

Knox's observations on fishing, 168.

Knox on food of herring, 235.

Kola, fishing station on White Sea, 73.

Kotzobue Sound, horrings fished by Esquimaux, 81. 
Kovema, herrings caught with seine, 80 .

Kronik van Holland, 134.

Lacepede on food, 50.

Laing's "Norway," 131.

Langebeck's History, 133.

Larne, herring visits irregularly, 72.

Lefevre's Report on Fishery-Board, 246.

recommends continuation of Board, 258 .

Letter as to Galway fishermen, 278.

Leuwenhock on food, 50.

Lewis Islands, fishery at, incrensing, 266.

Light and heat, influence, 31.

Lights used on American cnast, 32.

Limits at Galway Bay altered, 275.

- of fourteen miles for Scottish fishermen, 155.

List of curers of red herrings in 1777, 212 .

- of Dutch busses fitted out in 1857, 310 .

of Dutch busses fitted out in previous years, 310 .

Loch, on trade and fisheries, 211.

Loch Broom, herring fishery large in 1858, 306.

-_ Roag, visits of herring, 58.

Duich, visits of herring, 59 .

Carron, visits of herring, 60 .

Caroy, visits of herring, 60 .

Slapan, visits of herring, 60 .

Fyne and Loch Long, visits of herring, 61.

Lochinver, 307.

Lochs-Eribol, Inver, Kennard, Great Loch Broom, Little Loch Broom,

Ewe, Torridon, Urn, Moidart, Kintra, Linnhé, Craignish,-periodica visits, 57.

Lock fishing, 301.

Lofoden, summer fishery, 75 .

Loire, herrings limits south, 79 .

Long Island, herring visits, 57.

Lords of the Admiralty, 352.

Loss of boats and nets, 343 .

Lossiemoutl, herring visits, 63.

Lough Foyle, herring visits twice a-year, 72.

- Swilly, herring visits twice a-year, 78.

Louverex Recueil, 135.

Lowestoft, fishery of, 69 .

Lümfiord herring fishery ceased, 77.

Luminous appearance described, 240.

Mackenzie on food, 50.

Mackie on Wick harbour, 355 . 
Maclure's View of Glasgow, 172.

M'Gregor's "British America," 8\%.

Mearus herring-fishery, 66.

Majority of Commissioners of Inquiry in favour of brand, 316.

Man, Isle of, herring visits, 62.

Marlis on berrings, superstition regarding, 152.

Marseilles, fish-market at, 324.

Mary, Queen Dowager, of Hungary, 145.

May Island, 341.

Measure for herrings, 273.

Mediterranean, French fishery in, 324.

Memorial to the Board of Trade, 322.

Meteorological Society of Holland, 311.

Mickery Island, 341.

Migration, Descriftion of, chap. viii. page 84.

Miller, Hugh, on herring-fishery, 65.

Milt and roe, 29.

Minch, herring visits, 57.

Monnikendam, head quarters of pan fishery, 310.

Moon, influence of, 32 .

Morayshire Coast, herring visits, 63 .

Müller on food, 51.

Muriate of lime, 350 .

of magnesia, 350 .

of soda, pure salt, 350 .

Narwal, 87.

Natural History, chap. v. page 40.

Naval Coast Guard at Norway fishery, 302

Neill, Dr, as to herring, 37 ; as to food, 52 .

Nets, 91 .

Nets, illegal, 327.

Neucrantz on food, 50 .

Newhaven fishermen, battle with Fife tishermen, 340 . occupation during the year, 347. praised by Commissioner Barry, 297.

Night on the sea, 25.

Noel, De la Moriniere, 136.

Noordwyk, 311.

Noortkaper whale, herrings found in, 25.

Norfolk Coast, herring-fishery off, 68 .

North Berwick, 342.

Northumberland, herring visits, 68 .

Norway, Coasts of, herring visits, 74.

fishery in 1857,300 .

legislation, 302.

Norwegian fishery, 105. 
Norwegian fishery, visit to, described, 106. - lock-fishing, 108.

Nova Scotia, fishery of fat herrings, 82 .

Oak barrels, 350.

Observations on state of fisheries, 199.

Okotsk, shoals of herrings here, 80 .

Olaf Tryggresön's "Saga," 131.

Olaus Olavius, "History of Iceland," says herrings uncertain, 74.

Orkney, visits of herring, 55 .

Oyster fishermen within French boundary, 353.

Palinurus vulgaris, 87.

Pamphlets on fisheries, 196

Pan fishery, Dutch, 310.

Paris fish-market, 324 .

Penzance fishery, 69.

Periodical Visits, chap. vii. page 54.

Periodicity generally constant, 86 .

Philip De Mazieres, 134.

Phoce, 87.

Pilchard described, 41.

Pinkerton, 129.

Pomerania, herrings in April and May, off, 78.

Pommerage, Hist. Abbey of St Catharine, 141.

Power of spawn fecundated, 30.

Princess Royal, H.M.S., 341.

Privy Council Meeting, 1663, 171.

Queries, 5.

Progress of fecundated spawn, 30. of Fisheries, chap. ii. page 14.

Proposal for encouraging fishery, 198, 199.

Prussian mode of fishing, 108.

Quality at each locality constant, 85.

Quantities cured and exported, 16, 18, 212.

Quantity fished in $1862,344$.

— in North-east Coast, 344.

— in South-east District, 345.

—_ and sold fresh, 345.

- in West Coast, 345.

Quarrel between Scotland and Netherlands, 145.

Queen's Adrocate, 353.

Red or Smoked Herrings, Curing, Book II. chap. iii. page 120.

Red herrings mentioned in $1575,148$. no legislation as to curing, 351 . 
Religious ceremony at Claddagh before fishing, 71 .

Report as to tariff in France, 322.

Riga, small fishery here, 78.

Robin Hood's Bay, herring visits, 68.

Roe of cod imported to France for sardine fishery, 124.

Rondeletius on food, 50 .

Ross-shire Coast, herring visits, 63.

Roundstone, herring visits, 70 .

Row boats required, 352 .

Royal instructions to Sir William Alexander, 160.

- Physical Society, 342.

Society's Transactions, 235.

Rugen Island, herrings off", twice a-year, 78 .

Rutland, Coast of, visits uncertain, 73 .

Rymer's Fœdera, 162.

Sails to be marked, 328 .

Salmon, herrings found in stomach of, 36 . migration of, 89.

Salmon's chronology, 155.

Salt duties in Holland injurious, 308.

Salt-water fish ponds, value of, 31 .

Sancta Ottonis, 134.

Sand-eels, 48.

Sandy Bay, 81.

Sardines, French modes of cure, 124, 126.

Scheveningen, 311.

Scientific divings for spawn, 341.

Scoresby's remarks on food, $34,50,88$.

Scotland produces large supplies of fish of all kinds, 323 .

Scottish Act, James I., 1424, 141.

- James III., 1471, 143.

___ James IV., 1488 and 1491, 143.

- James V., 1540, 145.

_- James VI., 1573, 147.

- James VI., 1579 and 1584, 149.

James VI., 1585, 152.

James VI., 1587, 154.

Scottish Exchequer enforces tax for fishing, 150.

fishing in 1429, 142 .

herring busses for bounty, 1797, 222.

Nation maintains its right for exclusive fishing, 157 .

Parliament in 1661 passes $\Lambda$ ct for fishing, 163.

Parliamentary Records, 132.

Seafield, herring visits, 71 .

Seal tribe prey on herring, 35 .

Seining, 94, 99 . 
Seizure of Dutch ships by the Scotch in $1410,140$.

Selling herring fry, penalty for, 335 .

Shad, migration of, 89.

Shannon, river, herring visits, 71 .

Sheephaven Bay, herring visits, 70.

Sheet herring-fishing, 100.

Shetland, visits of herring, 54 .

Ship of war necessary on Irish Coast, 332.

Shoal spawning, 339.

Shoals arriving on coast, 349.

Shower of herrings, 57.

Sibbald's History of Fife, on herring fishery, 67.

Sinclair, Sir John, 225.

Size of herring at each locality constant, 85 .

Sizes of herrings on various coasts, 46 .

Skudesnæs, fishing off, 300.

Skye, herring visits, 60 .

Smith's Report on Fisheries, 161.

Smoked herrings, improperly mixed, 352.

Solinus' Ancient Account, 129.

Solway Firth, herring visits, 62.

Sonini's Buffon on food, 51.

Spanish salt much used, 351.

Spawn depositing, 29.

Spawning-ground swarms with other fishes, 340.

Specimens of herrings required by Board of Trade, 305.

Spottiswood's History of Scotland, 155.

Sprat described, 40, 89.

fishing in the Forth, limits may be fixed, 335.

Sprats cured in Norway, 127.

smoked, 127.

Squalus borealis, 88.

Stadtland, herring visits, 75 .

Staithes, herring visits, 68 .

Statistics of herring-fishery since 1848, 346.

- of herrings and freights, 240.

- cured, 258.

- materials, 20.

- people employed, 19.

Statute of herrings, 1357, 139.

Stettin importations, 16, 272.

St Ives, herring visits, 69.

St Monance, 341.

Stornoway, herring visits, 58.

Suggestions for improving herring fishery, 349 .

Sullivan's, Captain, Report, 316.

Sulphate of magnesia, 350 . 
Sulphate of lime, 350.

Summer and winter herrings constant, 83.

Sun injurious to herrings in boat, 349 .

Sunday, fishing on, 340 .

Sussex, herring visits, 69.

Sutherland Coast, visits of herring, 56 .

Sweden, herring fishery ceased, 76.

Swift, Dean, his letter on the herring-fishery, 190.

Swilly, Lough, trawling prohibited, 319.

Swynden's History of Great Yarmouth, 181.

Tables of progress since 1848,346 .

Tail, power of, 31 .

Tariff, French, new, 326.

Tartarus war steamer, 353 .

Tartary, Russian, Okotsk lierring-fishery, 80.

T'ax exacted for fishing herring from Dutch busses, 162.

from foreigners fishing herrings, 156.

Tay River, herrings inconsiderable, 66 .

Teiling, coast of, large shoals, but not fished, 73 .

Texel, off, herrings uncertain, 79 .

Throwing herring refuse into sea injurious, 354.

Thurso, visits of herring, 56 .

Time of selling fish in the "Mercat," 145.

Tobermory fishery, 220.

Tonnage bounty, 1755, 208

Torridon, Loch, great fishing in, 241.

Tour on Scottish Coast by Commissioner Barry, 296.

Trade in red herrings declining, 122.

Traill on herring fishery, 66 .

Transactions of Highland Society, 173.

Trawl-boat burned in Galway Bay by fishermen, 330.

fishing can be prohibited, 329.

Treaty between Louis XI. and Charles of Burgundy, 141.

Trichecus rosmarus, 87.

Troon, visits of herring, 62 .

'Tuckey's Maritime Geography, 80.

Tunny, 324.

Turner's Sacred History as to Food, 50.

Twaite shad described, 41.

Use of beam-trawls opposed in Ireland, 331.

Utrecht, Meteorological Society at, 311.

Valenciennes, Cuvier as to dog-fish, 36.

herrings taking by scine, 71 .

Vernon's plans and proposals, 195. 
Virginia, herring-fisheries off coast, 81.

Visiting Highland lochs, 27.

Von Wright on food of herring, 51.

Wade, Thomas, report as to trawling, 280.

Walker's scheme for promoting fislieries, 196.

War-steamers required, 352 .

Water Telescope, 33.

Waterford harbour, trawling prohibited, 320.

Wellman's letter to George Traill, M.P., 266.

West Manæ, Iceland, visits of herring irregular, 74 .

Wexford, Coast of, trawling prohibited, 320.

Whales pursuing herrings, 65.

Whitebait described, 41.

White Sea, herrings abundant, 73.

Whiting destructive of herring, 36 .

Wick fishing, 1862, 342 .

- former state of fishery at, 320 .

- Larbour, addition to, by British Fishing Society, 245, 302.

- harbour injured by storm in 1827, 236.

- herring visits, 63 .

_... Statistics, 313.

Wicklow Coast, herring season changed on, 72.

Wilson, James, on destructive habits of gannet, 37.

- the Naturalist, description of fishery of Wick, 241.

Wind injurious to herrings in boat, 349 .

Winter and summer herrings constant, 83.

Wismar, fishery here, 78.

Wollenhove, 311.

Wolsey, Cardinal, presents red herrings, 149.

Yairs, 94.

Yairs' account of Scotch trade in Netherlands, 137, 145.

Yarmouth, fishery of, 68, 95.

- L herring fair at, 136.

- petition against fishery duties, 323.

Yarrell's Clupea Leachii, 83.

- Fishes, 89.

Yearly occupation of fishermen, 347.

Yorkshire Coast, herring visits, 68.

Zuyder Zee, inferior herrings in November, 79, 310. 

